\title{
GUIA PARA IDENTIFICAÇÃO DOS TUBARÕES, RAIAS E QUIMERAS DO ESTADO RIO DE JANEIRO (CHONDRICHTHYES: ELASMOBRACHII E HOLOCEPHALI]
}

\author{
IDENTIFICATION GUIDE OF SHARKS, BATOIDS AND CHIMAEROIDS FROM RIO DE JANEIRO STATE \\ (CHONDRICHTHYES: ELASMOBRACHIIE HOLOCEPHALI)
}

\section{GUIIA PARA IDENTIFICACIÓN DE TIBURONES, RAYAS Y QUUMERAS DEL ESTADO DE RIO DE JANEIRO (CHONDRICHTHYES: ELASMOBRACHIIE HOLOCEPHALI)}

\author{
Ulisses Leite Gomes ${ }^{1}$ \\ Hugo Ricardo Secioso Santos ${ }^{1}$ \\ Otto Bismarck Fazzano Gadig² \\ Camila Negrão Signori \\ Marcele Moura Vicente
}

\section{Resumo}

Este trabalho apresenta um guia de identificação simplificado das espécies de tubarões, raias e quimeras (conjuntamente chamados de peixes cartilaginosos) que ocorrem na costa do Estado do Rio de Janeiro, Brasil. É direcionado a pesquisadores, professores universitários, gestores públicos estudantes de biologia, oceanografia, veterinária, mergulhadores, pescadores, outros profissionais ligados às ciências do mar, ou mesmo o público em geral que se interesse pela vida marinha e pelos Chondrichthyes. As chaves de identificação são baseadas em caracteres morfológicos e morfométricos externos, de fácil conferência, mesmo por leigos. Para cada ordem, família, gênero e espécie, são apresentados nomes populares, caracteres morfológicos distintivos, amplitude de comprimento, distribuição espacial, hábitos, biologia e outras observações, quando pertinentes. Para a área estudada são reconhecidos, neste guia, tubarões: seis Ordens, 20 Famílias, 37 gêneros e 68 espécies; raias: quatro Ordens, 14 Famílias, 24 gêneros e 39 espécies, e finalmente, quimeras: uma Ordem, três Famílias, três gêneros, quatro espécies.

Palavras-chave: Identificação; Condrícties; Rio de Janeiro; Brasil.

\begin{abstract}
This work provides a simplified identification guide for sharks, rays and chimaeroids species (known as cartilaginous fishes) that occur off Rio de Janeiro State coast, Brazil. It is dedicated to researchers, professors, students from biological, oceanographic

1 Laboratório de Taxonomia de Elasmobrânquios, Departamento de Zoologia, Instituto de Biologia, Universidade do Estado do Rio de Janeiro - RJ

2 Laboratório de Pesquisa de Elasmobrânquios, Campus Experimental do Litoral Paulista, São Vicente $-\mathrm{SP}$

3 Departamento de Oceanografia Biológica, Instituto Oceanográfico, Universidade de São Paulo- São Paulo - SP
\end{abstract}


and veterinary sciences, as well as divers, fishermen, other related professionals, and the general public who are interested in marine life and Chondrichthyes. The identification keys are based on external morphological and morphometric characters which are easy to understand and check also by non-experts. For each order, family, genus and species, we provide common names, distinctive morphological characters, size range, spatial distribution, habits and biology, and other observations when pertinent. Six orders, 20 families, 37 genera and 68 species of sharks, four orders, 14 families, 24 genera, 39 species of batoids and one order, three families, three genera and four species of chimaeras are recognized.

Key words: Identification; Chondrichthyans; Rio de Janeiro; Brazil.

\section{Resumen}

Este trabajo presenta una guía de identificación simplificada de las especies de tiburones, rayas y quimeras (peces cartilaginosos) que ocurren en la costa del Estado de Río de Janeiro, Brasil. Este trabajo se dirige a investigadores, profesores universitarios, estudiantes de biología, oceanografía, veterinaria, buceadores, pescadores, otros profesionales vinculados al mar, e incluso el público en general que se interesa por la vida marina y los Chondrichthyes. Las llaves de identificación se basan en caracteres morfológicos distintivos, tamaño, distribuición, hábitos y biología, y otras observaciones cuando corresponden. Se reconecen en esta guía para el area abordada seis órdenes, 20 familias, 37 géneros y 68 espécies de tiburones; cuatro órdenes, 14 familias, 24 géneros y 39 espécies de rayas; quimeras: un orden, tres familias, tres géneros, cuatro espécies de quimeras.

Palabras-clave: Identificación; Condríctios; Rio de Janeiro; Brasil.

\section{INTRODUÇÃO}

O conhecimento sobre a riqueza e a diversidade de espécies de uma região é o primeiro passo a ser dado por aqueles que pretendem estudar uma população ou comunidade dentro de uma abordagem ecológica básica ou aplicada. Tal conhecimento é fundamental por oferecer subsídio ao manejo da biodiversidade, pois sem ele não é possível estabelecer planos estratégicos e políticas públicas que permitam a conservação do patrimônio natural, nem realizar trabalhos básicos e aplicados sobre biologia ou história natural dos organismos envolvidos.

A gigantesca e aclamada biodiversidade brasileira é pouco contemplada no que se refere à produção de literatura acessível que auxilie na identificação das espécies, e esse fato é muito acentuado em relação à fauna marinha.

Os tubarões, famosos por seus raros ataques contra seres humanos, fazem parte de um grupo muito antigo de vertebrados, os peixes cartilaginosos (Classe Chondrichthyes), junto também com as raias e as quimeras. Importantes predadores do ecossistema marinho, os tubarões e raias (Subclasse Elasmosbranchii) 
desempenham papel de destaque na manutenção do equilíbrio delicado que rege as relações entre presa e predador no meio em que vivem.

Os peixes cartilaginosos possuem numerosos atributos anatômicos e fisiológicos que os destacam dentre os animais "vertebrados". Essa é uma linhagem antiga, que surgiu há um pouco mais de 400 milhões de anos e até hoje habita os oceanos do mundo, com sucesso. Eles dividem a supremacia do ambiente aquático com os peixes ósseos, apesar destes últimos serem representados por mais de 23,000 espécies, contra apenas cerca de 1.250 espécies de peixes cartilaginosos (Didier, 2004, Weigmann, 2016; Last et al., 2016).

Como afirmava o saudoso professor Dr. Gustavo Wilson Nunan os "peixes não conhecem fronteiras". Apesar de termos ciência dessa verdade, escolhemos a área dos limites geopolítico do Estado do Rio de Janeiro em função da praticidade de ter acesso aos postos de pesca, das coleções de peixes com acervo representativo da região (Museu Nacional/Universidade Federal do Rio de Janeiro, Universidade do Estado do Rio de Janeiro e Universidade Santa Úrsula), e por representar uma área ambiental de importância na distribuição da ictiofauna do oceano Atlântico Sul-Ocidental, pela ocorrência do fenômeno da ressurgência (Nunan, 1992). Nessa área, o afloramento da Água Central do Atlântico Sul (ACAS), ocasionado por ação conjunta entre o vento de leste e o desenho da costa, promove o aumento da biomassa planctônica e o conseqüente aumento na produtividade.

Desde a primeira edição do "Guia para a identificação de tubarões e raias do Rio de Janeiro”, em Gomes et al., 2010, os estudos dos peixes cartilaginosos sofreram aumento, no âmbito de sua biologia e na evolução do conhecimento do grupo. Neste último caso, com o incremento do emprego da sistemática molecular, uma revolução ocorreu na classificação dos peixes cartilaginosos, acrescentando ordens, famílias e consequentemente, a descrição de novas espécies (e.g. Human et al., 2006; Di Dario et al., 2011; Naylor et al., 2012; Last et al., 2016; Soares et al., 2019, White et al., 2018). Em função das novas ocorrências e de descrição de novas espécies de elasmobrânquios, assim como o registro de três espécies de quimeras (ou peixes-elefante) para a área, houve a necessidade de publicar esse novo guia, acrescentando também as quimeras.

O propósito principal desta obra é oferecer um guia para identificação dos tubarões, raias e quimeras que ocorrem na costa do Estado do Rio de Janeiro no Brasil, que possa ser utilizado por pesquisadores, professores universitários, gestores públicos, estudantes de biologia, oceanografia, veterinária, mergulhadores, pescadores, outros profissionais ligados às ciências do mar, e mesmo o público em geral que se interesse pela vida marinha e pelos Chondrichthyes. 


\section{GENERALIDADES SOBRE OS CHONDRICHTHYES (TUBARÕES, RAIAS E QUIMERAS)}

Os peixes cartilaginosos (classe Chondrichthyes) são representados pelas subclasses Elasmobranchii (tubarões e raias) e Holocephali (quimeras e peixeselefante). São conhecidas atualmente cerca de aproximadamente 1.250 espécies (Didier,1995, 2004; Weigmann, 2016 e Last et al., 2016 c).

Esse grupo de vertebrados compartilha as seguintes características: esqueleto cartilaginoso calcificado; crânio formado por uma única peça esquelética, sem suturas; um par de órgãos copuladores nas nadadeiras pélvicas dos machos e pele revestida por dentículos dérmicos, também citados na literatura como "escamas placóides" (Figueiredo, 1977; Lebrun, 2001).

Os elasmobrânquios e holocéfalos são facilmente diferenciados entre si principalmente pelo número de fendas branquiais. Tubarões e raias possuem de cinco a sete pares de arcos branquiais em cada lado da cabeça, que se abrem separadamente na forma de fendas branquiais externas. As quimeras possuem cinco pares de arcos branquiais de cada lado da cabeça, mas todos cobertos externamente por uma placa cartilaginosa revestida de pele. Dessa forma, há apenas uma abertura para o meio externo em cada lado da cabeça (semelhante, em forma, aos opérculos dos peixes ósseos) (Figueiredo, 1977; Lebrun, 2001).

Para os elasmobrânquios, a diferenciação entre os tubarões e as raias é normalmente feita com facilidade. A maioria dos tubarões tem o corpo fusiforme e roliço, enquanto nas raias o padrão geral do corpo é achatado dorsoventralmente. Nos tubarões, as nadadeiras peitorais destacam-se da cabeça. Já em quase todas as raias, as nadadeiras peitorais se fundem ao contorno da cabeça, formando o "disco".

Também, a posição das aberturas branquiais ajuda na diferenciação de tubarões e raias. Nos primeiros as fendas branquiais estão em posição lateral na cabeça, enquanto nas raias as fendas são ventrais à cabeça.

\section{Distribuição e hábitat}

Tubarões, raias e quimeras são animais principalmente marinhos, embora algumas espécies de Elasmobrânquios possam penetrar em água doce como o tubarão cabeça-chata (Carcharhinus leucas) e o peixe-serra (Pristis pristis). A minoria, como as raias da família Potamotrygonidae, vivem exclusivamente em água doce. Curiosamente algumas raias da família Potamotrygonidae retornaram aos ambientes de águas salobras e até marinho, como as espécies Styracura schmardae (Werner, 1904) e Styracura pacifica (Beebe \& Tee-Van, 1941) (Carvalho et al., 2016). Os Chondrichthyes estão distribuídos circumglobalmente. Essa ampla distribuição reflete a grande adaptação desses animais a seu ambiente. A maioria das espécies habita áreas costeiras, sobre a plataforma continental, enquanto a riqueza e diversidade de 
elasmobrânquios são menores em águas polares e grandes profundidades, superiores a $3.000 \mathrm{~m}$ (Gadig, 2001).

As quimeras ou peixes-elefante são totalmente marinhos. Seus representantes vivem preferencialmente afastados da costa, em águas profundas, chegando a mais de 2.500 metros de profundidade. Suas espécies são encontradas em todos os oceanos (Didier, 1995, 2004).

\section{Reprodução}

Os peixes cartilaginosos apresentam características singulares no que se refere a seu modo de reprodução, envolvendo uma grande variação na estratégia de nutrição dos fetos/embriões durante a gestação. Espécies ovíparas depositam ovos e o desenvolvimento do embrião ocorre fora do corpo materno. Este é o caso de todas as raias-emplastros (ordem Rajiformes) e muitas espécies de tubarões (por exemplo, os cação-gato, da família Scyliorhinidae), e todas as quimeras. Nas espécies vivíparas, o embrião se desenvolve dentro do corpo materno, utilizando os seguintes recursos de nutrição embrionária: 1) viviparidade lecitotrófica - o embrião se nutre por meio de bolsa vitelínica (Hexanchiformes, Pristiformes, Torpediniformes e Rhinopristiformes). Nos Myliobatiformes o embrião recebe nutrição adicional através de estruturas tubulares pequenas que revestem a parede interna do útero (chamadas trofonematas), que secretam uma substância rica em lipídios;2) viviparidade ovofágica - o embrião se nutre de óvulos e ovos (oofagia) liberados pela mãe durante a gestação (Lamniformes). No tubarão mangona (Carcharias taurus) ocorre a adelfofagia - em que o embrião consome outros embriões; 3) viviparidade placentária - o embrião se nutre por meio de ligação placentária com a mãe, como nos tubarões das famílias Carcharhinidae (exceto no tubarão-tigre, Galeocerdo cuvier) e Sphyrnidae.

\section{Biologia sensorial}

Os peixes cartilaginosos são formidavelmente desenvolvidos sensorialmente, com uma série de órgãos devotados à percepção de estímulos de várias naturezas. A visão, o olfato, a linha lateral e as Ampolas de Lorenzini são recursos importantes na atividade de predação dos elasmobrânquios.

Com relação aos tubarões, estudos demonstraram que estes têm uma excelente capacidade de visualização, principalmente em ambientes de baixa luminosidade, graças às estruturas refletoras de luz situadas por trás da retina, chamadas de tapetum lucidum.

O olfato é muito desenvolvido. A água passa pelas narinas, situadas na parte ventral do focinho, deixando estímulos químicos de substâncias diluídas na água. 
Não só o sangue pode ser atraente aos tubarões, mas também urina, fezes, óleos, ácidos, etc.

A linha lateral é responsável pela percepção dos estímulos mecânicos, e consiste de milhares de poros distribuídos em fileira ao longo dos flancos, no dorso e ventre (este último no caso das raias). Internamente esses poros se comunicam com um canal cheio de células ciliadas nervosas denominadas neuromastos, as quais captam as vibrações de um peixe ferido, ou qualquer outro movimento na água.

As ampolas de Lorenzini são estruturas situadas na região ventral e lateral da cabeça dos tubarões, e amplamente distribuídas na superfície ventral das raias. São responsáveis pela percepção de estímulos eletromagnéticos. A sensibilidade a estímulos elétricos é muito útil quando esses animais buscam suas presas enterradas no substrato, localizando o campo elétrico emitido pela sua potencial vítima.

\section{Pesca e conservação de peixes cartilaginosos}

As espécies de peixes cartilaginosos são fundamentais ao ecossistema marinho, pois muitas são predadoras do ápice da cadeia alimentar. Com isso, consomem enorme diversidade de presas, contribuindo com a manutenção do equilíbrio entre as populações marinhas. Apesar disso enfrentam um grande problema para manter sua população, por possuírem um ciclo de vida longo, crescimento lento, baixa fecundidade relativa e maturidade sexual tardia. Isso é um grande problema para a conservação de peixes cartilaginosos, já que a excessiva pesca têm levado numerosas espécies ao declínio populacional, chegando, muitas delas, à beira da extinção (Gadig, 2001). Isto porque a capacidade de reposição de uma população é muito menor do que a intensidade com que é capturada. Em palavras mais simples, o número de peixes cartilaginosos que morrem todos os anos é superior aos que nascem. No Brasil, as quimeras não são frequentemente comercializadas devido as suas raras capturas. São geralmente pescadas ao acaso e expostas em peixarias como atração, ou depositadas em coleções ictiológicas (Di Dario et al., 2001), com isso, pouco se conhece sobre a biologia de suas espécies.

O aproveitamento de produtos e subprodutos dos Chondrichthyes para consumo humano vão desde sua carne, nadadeiras, pele, fígado, dentes e vértebras. A comercialização de tais produtos, em algumas regiões, pode pesar muito na balança econômica local. 


\section{MORFOLOGIA GERAL EXTERNA}

\section{Forma do corpo}

Na maioria das espécies de tubarões o corpo é fusiforme (Fig. 5), bem adaptado à natação. Algumas espécies, no entanto, não obedecem rigorosamente a este desenho. Os cações-anjo, família Squatinidae (Fig. 4), têm o corpo achatado dorso-ventralmente, como o das raias.

Nas raias o desenho básico é o de um corpo achatado dorso-ventralmente, mais adaptado à vida junto ao substrato. As nadadeiras peitorais são largas e expandidas lateralmente, fundidas à cabeça numa silhueta contínua. Este conjunto é denominado "disco". Existem formas mais alongadas e que se assemelham muito aos tubarões, como as raias-serra (família Pristidae) ou as raias-viola (família Rhinobatidae). Essas espécies possuem o corpo alongado, com a região posterior ao disco desenvolvida, onde se posicionam as nadadeiras dorsais e a nadadeira caudal .

As quimeras possuem o corpo um tanto fusiforme tornando-se delgado em direção à região caudal. A pele não apresenta dentículos dérmicos, o que confere uma textura lisa ao tato. A primeira nadadeira dorsal apresenta um espinho móvel e pungente. A segunda nadadeira dorsal pode ser muito longa, acompanhando todo o dorso do animal, ou curta. A nadadeira anal pode estar ausente (Fig. 350), rudimentar ou bastante desenvolvida (Fig. 349). O focinho varia desde muito alongado (Rhinochimaeridae) (Fig. 348), podendo apresentar uma pequena probóscide (Callorhynchidae) (Fig. 349) ou um focinho rombo ou pouco desenvolvido (Chimaeridae) (Fig. 350). Todas as quimeras possuem seis placas dentárias: dois pares superiores e um par inferior.

Muitos machos quando atingem a maturidade apresentam um tipo de gancho na cabeça, denominado tenáculo cefálico. Sua função parece ser o de prender a fêmea no momento da cópula. Um tenáculo pré-pélvico também é encontrado. Possuem órgãos copuladores (ou clasperes) pares, cada um deles podendo ou não ser bifurcado na extremidade.

\section{Cabeça}

A cabeça de um peixe cartilaginoso é definida como a parte que vai desde a ponta do focinho até a última fenda branquial. Nos tubarões, o focinho é normalmente pronunciado, podendo ser cônico (Fig. 16) ou arredondado (Fig. 18). Muitas espécies, porém, apresentam focinho com formas específicas, como os tubarões-martelo (família Sphyrnidae), que têm expansões laterais características na região prébranquial da cabeça (Fig. 118). Nas extremidades dessas expansões estão situados os olhos e as fendas nasais. 
Os olhos dos tubarões normalmente estão em posição lateral, e podem ser circulares ou elípticos, de tamanhos bem variados. Espécies da ordem Carcharhiniformes possuem uma membrana protetora móvel, denominada membrana nictitante (Figs. 11 e 120). Esta fica retraída, mas pode cobrir os olhos rapidamente em situação de predação, impacto mecânico ou luminosidade. Em todas as raias e em muitos tubarões podem ser encontrados espiráculos, que são fendas auxiliares à respiração. Os espiráculos têm forma circular e são posicionados atrás de cada olho (Figs. 45 e 251).

A boca é arqueada e transversal, situada na parte ventral da cabeça (Fig. 18) Em alguns tubarões, como os cações-anjo e o tubarão-baleia (famílias Squatinidae e Rhincodontidae) a boca é quase terminal ou terminal (Fig. 4). As aberturas nasais pares se posicionam anteriormente à boca (Fig. 127). Em algumas espécies, como o cação-lixa (Ginglymostoma cirratum, família Ginglymostomatidae), um par de barbilhões carnosos se projeta, cada qual na margem interna da respectiva abertura nasal (Fig. 8, seta).

Tubarões podem ter de cinco a sete pares de fendas branquiais. Nos representantes da ordem Hexanchiformes, por exemplo, podem ser encontradas seis ou sete fendas de cada lado da cabeça, dependendo da espécie (Figs. 19 e 20). A posição lateral das fendas branquiais é quase uma regra entre os tubarões, embora no caso dos cações-anjo (família Squatinidae) estas fendas se posicionem láteroventralmente.

Nas raias os olhos e espiráculos se posicionam no dorso da cabeça. Isso permite ao animal uma ampla visão do ambiente acima, já que passam a maior parte do tempo junto ao substrato, ou mesmo enterradas nele. As raias-elétricas (ordem Torpediniformes) apresentam margem anterior do focinho quase reta (Fig. 258) ou arredondada (Fig. 260). Nas raias-manta (família Mobulidae) existem projeções laterais de cada lado da cavidade bucal (Fig. 335), com função básica de conduzir e afunilar a água para a boca. Nas raias-ticonha (família Rhinopteridae), a parte frontal da cabeça é truncada, com um entalhe mediano (Fig. 339), enquanto nas raias-sapo e raias-chita (família Myliobatidae), o focinho termina em uma projeção carnosa simples (Fig. 345). Nessas três Famílias, a cabeça é claramente mais alta do que o restante do corpo, de modo que os olhos e espiráculos ficam situados na parte lateral da cabeça.

Nas raias os espiráculos são mais desenvolvidos do que nos dos tubarões, e capazes de bombear a água circundante para as fendas branquiais. Esse é um recurso especialmente interessante quando o animal está enterrado na areia ou mesmo quando está com sua cavidade bucal ocupada com alimento.

Na maioria das raias, a boca é transversal e pouco angulosa. Muitas vezes está conectada às narinas através de sulcos na pele, o que resulta na formação de uma aba nasal. Sua morfologia é frequentemente empregada como caráter taxonômico. As fendas branquiais são invariavelmente ventrais, em número de cinco pares, na grande maioria das espécies.

Nas quimeras, a cabeça termina na única abertura branquial lateral (Fig. 348). 


\section{Nadadeiras ímpares e pares}

Nos tubarões observamos normalmente duas nadadeiras dorsais. Os tubarões da ordem Hexanchiformes possuem apenas uma nadadeira dorsal (Fig. 7). Em muitos Lamniformes (famílias Lamnidae e Alopiidae), a segunda nadadeira dorsal é muito pequena, quase uma "pínula" (Fig. 94). Alguns tubarões têm a primeira nadadeira dorsal bem longa semelhante a uma crista (e.g. espécies de Centroscymnus, ver Fig. 63).

Muitos representantes da ordem Squaliformes (e.g. famílias Squalidae e Etmopteridae), possuem um espinho emergindo da base da margem anterior das duas ou apenas de uma nadadeira dorsal (Fig. 52). O formato, o tamanho e a posição relativa das nadadeiras variam grandemente, sendo essa característica muito empregada na taxonomia de tubarões.

Assim como as nadadeiras dorsais, as peitorais apresentam forma, tamanho e posição relativa ao corpo bastante variada. Sua origem normalmente fica abaixo da quarta ou quinta fenda branquial (Fig. 211), ou imediatamente atrás da quinta fenda (Fig. 45). Nos cações-anjo (família Squatinidae), as nadadeiras peitorais são expandidas lateralmente, lembrando muitas espécies de raias. Entretanto não são fusionadas à cabeça, mas separadas dela por um entalhe profundo onde se encontram, quase escondidas, parte das fendas branquiais.

O par de nadadeiras pélvicas, situado próximas à cloaca, abriga os órgãos copuladores (os clásperes ou mixopterígios). O grau de calcificação (conferindo rigidez) dos clásperes indica a maturidade sexual dos individuos. As fêmeas não apresentam modificações estruturais nas nadadeiras pélvicas, de forma que este caráter representa, externamente, a distinção sexual entre os indivíduos.

A nadadeira anal existe em muitas espécies, posicionada entre o par de nadadeiras pélvicas e o lobo inferior da nadadeira caudal (Fig. 3). Esta nadadeira é ausente em todos os representantes da ordem Squaliformes e Squatiniformes e também em todas as raias.

A nadadeira caudal apresenta um lobo superior e um inferior. Alguns tubarões, como os tubarões-raposa (Família Alopiidae), apresentam o lobo superior extremamente desenvolvido, correspondendo aproximadamente à metade do comprimento total do corpo (Fig. 94). Já muitos tubarões da ordem Lamniformes (especialmente a Família Lamnidae) possuem os dois lobos com tamanhos aproximadamente iguais, com aspecto de meia-lua (Fig. 106). No caso dos caçõesanjo (Família Squatinidae), o lobo inferior é o mais desenvolvido (Fig. 77).

Para a descrição das nadadeiras das raias, é didaticamente interessante considerar a existência de dois grandes grupos morfológicos, de acordo com a forma geral do corpo. No primeiro deles, representado pelas ordens Rhinopristiformes e Torpediniformes, a porção do corpo posterior ao disco é musculosa, com duas nadadeiras dorsais e a nadadeira caudal destacada (Fig. 255). Ainda neste grupo de raias, a nadadeira caudal é desenvolvida. Normalmente o lobo superior é maior (em 
todos os Rhinopristiformes) (Fig. 257) ou ambos de tamanho similares (em alguns Torpediniformes).

O segundo grupo é caracterizado por raias cuja porção do corpo posterior ao disco é afilada (ordem Rajiformes) (Fig. 285) até extremamente filamentosa (na maioria dos Myliobatiformes, Fig. 347). Nesse grupo a nadadeira dorsal, quando presente, é muito pequena. Em Rajiformes comumente são encontradas duas pequenas nadadeiras dorsais quase rudimentares, localizadas na porção posterior da cauda. A nadadeira caudal nessa ordem também é diminuta ou ausente (Fig. 286). Já nos Myliobatiformes, a nadadeira dorsal, quando presente, normalmente se situa na base ou medianamente na caudal (Fig. 345). A região caudal é quase ou totalmente filamentosa e desprovida de nadadeira caudal (e.g., Dasyatidae, Rhinopteridae, Myliobatidae e Mobulidae, Fig. 319). Dentro de Myliobatiformes, as raias-prego (Família Dasyatidae) não possuem nadadeiras dorsais ou caudais, mas o filamento caudal frequentemente apresenta pregas ou abas dérmicas (parecendo dobras de pele) longitudinais na sua superfície dorsal e/ou ventral.

Nas quimeras as nadadeiras peitorais são bem desenvolvidas e bastante flexíveis. A nadadeira caudal pode ser filamentosa ou não. A primeira nadadeira dorsal é predominantemente triangular e precedida por um espinho flexível. A segunda nadadeira dorsal é mais baixa, podendo ser curta (Callorhynchidae, Fig. 349) ou alongada, percorrendo todo o dorso do animal (Rhinochimaeridae e Chimaeridae, Figs. 348 e 350$)$.

\section{Revestimento corpóreo externo}

A pele dos elasmobrânquios é revestida por "escamas placóides" ou "dentículos dérmicos". Como o próprio nome indica, o revestimento é, na verdade, o arranjo diversificado de milhares de pequeninos dentes, os quais são estruturalmente semelhantes aos dentes das arcadas dentárias, com esmalte, dentina, cavidade pulpar e vasos sanguíneos.

Os dentículos dérmicos apresentam forma e disposição variada, sendo utilizados muitas vezes na identificação das espécies.

Os elasmobrânquios podem apresentar na superfície do corpo várias estruturas e ornamentações que, de fato, são dentículos dérmicos modificados. No caso dos tubarões, podem ser citados os espinhos que precedem as nadadeiras dorsais, os tubérculos, que são dentículos dérmicos de tamanho destacado dos demais e com aspecto de pequenos escudos irregulares, (e.g., tubarão-espinhoso, família Echinorhinidae, Fig. 28), e os rastros branquiais do tubarão-peregrino (Cetorhinus maximus), que desempenham a função retentora de alimento.

Nas raias existem numerosas modificações dos dentículos dérmicos, como os espinhos, que podem estar organizados em fileiras na região mediana do dorso (Fig. 272) ou dispersos (Fig. 320) por todo o disco. 
Em muitos representantes de Rajiformes, há ganchos na face dorsal das nadadeiras peitorais de machos adultos, que parecem auxiliar no ato da cópula, retendo a fêmea (Fig. 284).

Os ferrões caudais (Fig. 324), presentes apenas nos representantes da ordem Myliobatiformes, também são modificações de dentículos dérmicos.

As quimeras não apresentam dentículos dérmicos, sendo sua pele lisa ao tato.

\section{Outras características morfológicas externas}

Além do padrão morfológico geral descrito acima, esses peixes possuem outras características secundárias, que são empregadas como ferramenta complementar na sua identificação.

Várias espécies de tubarões, principalmente do gênero Carcharhinus (tubarõescinzentos) possuem uma tênue crista dérmica longitudinal no dorso (Fig. 199), entre as duas nadadeiras dorsais. Essa característica os separam em dois grandes grupos de espécies. Cações-frango (gênero Rhizoprionodon) apresentam um par de cristas dérmicas precedendo a nadadeira anal, denominadas cristas pré-anais; (Fig. 171), que são melhor visualizadas em exemplares sub-adultos e adultos. A região do pedúnculo caudal de algumas espécies de tubarões e raias pode apresentar cristas dérmicas laterais (carenas), presentes nos tubarões da família Lamnidae (Fig. 107) e alguns Carcharhinidae (e.g., como o tubarão-tigre, Galeocerdo cuvier). No tubarão-baleia, Rhincodon typus, as carenas se duplicam anteriormente nos flancos, projetando-se bilateralmente, de cada lado da primeira nadadeira dorsal (Fig. 115).

Ainda no pedúnculo caudal, alguns tubarões possuem sulcos précaudais superior e inferior. Na Família Carcharhinidae os sulcos pré-caudais estão posicionados na porção superior (Fig. 178) enquanto nos Lamniformes o sulco précaudal pode ser encontrado na porção inferior.

Na cabeça podem ser observadas várias estruturas, tais como os sulcos labiais superior e inferior (Mustelus canis, Fig. 157), margeando as arcadas dentárias superior e inferior.

As raias também exibem diversificação morfológica associada à superfície ventral do corpo, como é o caso da região que envolve as narinas e a abertura nasal. A conexão entre as fendas nasais e boca formam dobras de pele conhecidas como "cortinas nasais" ou "abas nasais", cujo formato é útil na diferenciação de vários grupos de raias.

Os principais caracteres externos utilizados na identificação das quimeras são: o formato do focinho, a presença ou não de nadadeira anal e o formato das nadadeiras caudal e da segunda nadadeira dorsal. A distribuição dos canais da linha lateral na cabeça também pode ser útil na taxonomia desse grupo. 


\section{MATERIAIS E MÉTODOS}

As informações aqui contidas são baseadas em observações de campo, a bordo de embarcações de pesca e de pesquisa, e do acompanhamento de desembarque de pescado em praias e portos. Também foram consideradas fotografias e peças anatômicas, como arcadas dentárias e rostro com serra (peixe-serra), encontrados em colônias de pesca e casas de pescadores. Foram consultados os acervos das seguintes coleções científicas: Museu Nacional do Rio de Janeiro, Museu de Zoologia de São Paulo (MZUSP), Universidade do Estado do Rio de Janeiro (UERJ), Universidade Santa Úrsula, Rio de Janeiro (USU) e do Núcleo de Pesquisa e Estudo em Chondrichthyes, em Santos-SP. Esses exemplares podem ser encontrados nas seguintes referências de nossos estudos: Gomes et al. (1987), Barbosa \& Gomes (1998), Gadig (2001), Gomes (2002), Soares et al. (2016) e Viana et al. (2016). Também foi feita a revisão e análise de informações disponíveis na literatura especializada: Miranda Ribeiro (1907, 1923), Bigelow \& Schroeder $(1948,1953,1957)$, Miranda Ribeiro (1961), Springer $(1966,1979)$; Gilbert (1967), Figueiredo (1977), Roux (1979), Garrick (1982), Compagno (1984 a,b. 2001), Batista (1987), Notobartolo-di-Sciara (1987), Alecrim-Santos et al. (1988), Tomás \& Gomes (1989), Moreira et al. (1993), Gadig \& Rosa (1996), Tomás \& Tutui (1996), Heemstra (1997), Carvalho (1999), Lessa et al. (1999), Buckup et al. (2000), Menni \& Stehmann (2000), Gomes \& Paragó (2001), Hennemann (2001), Paragó (2001), Gomes \& Picado (2001), Menezes et al. (2003), Gomes et al (2006), Carvalho (2005), Lima et al (2009), Santos (2007); Di Dario (2011); Vaz \& Carvalho (2013, 2018), White (2014), Vaz (2015), Soares et al (2015, 2016, 2019); Viana et al. (2016), Yokota et al (2016) e Yokota \& Carvalho (2017) .

Uma lista das espécies registradas para o Rio de Janeiro é apresentada. Os respectivos nomes populares (vulgares) são preferencialmente os utilizados na região estudada. A classificação foi baseada nos recentes trabalhos de revisão taxonômica (Carvalho et al. 2016; Last et al., 2016 a, b, c; Stone \& Shimada, 2019, Viana et al. 2016; Weigmann, 2016, White et al. 2018). As chaves de identificação são aplicáveis principalmente para as espécies na área estudada (Fig. 1). As principais medidas morfométricas citadas foram:

- Comprimento total (sigla CT): medida da extremidade anterior do focinho até a margem posterior, mais distal, da nadadeira caudal;

- Largura do disco (sigla LD): medida tipica para raias, representa a maior medida dos extremos distais das nadadeiras peitorais (que formam o disco nas raias);

- Comprimento do disco (sigla $\mathrm{CD}$ ): particularmente utilizada em raias; medido da ponta do focinho até a margem posterior da nadadeira peitoral (Figs. 264 e 265);

- Comprimento da cauda (também particularmente utilizada em raias): tem início na axila da nadadeira pélvica até a extremidade final da cauda (ou da nadadeira caudal, quando existente) (Figs. 264 e 265). 
A área estudada: a costa do Estado do Rio de Janeiro (Fig. 1)

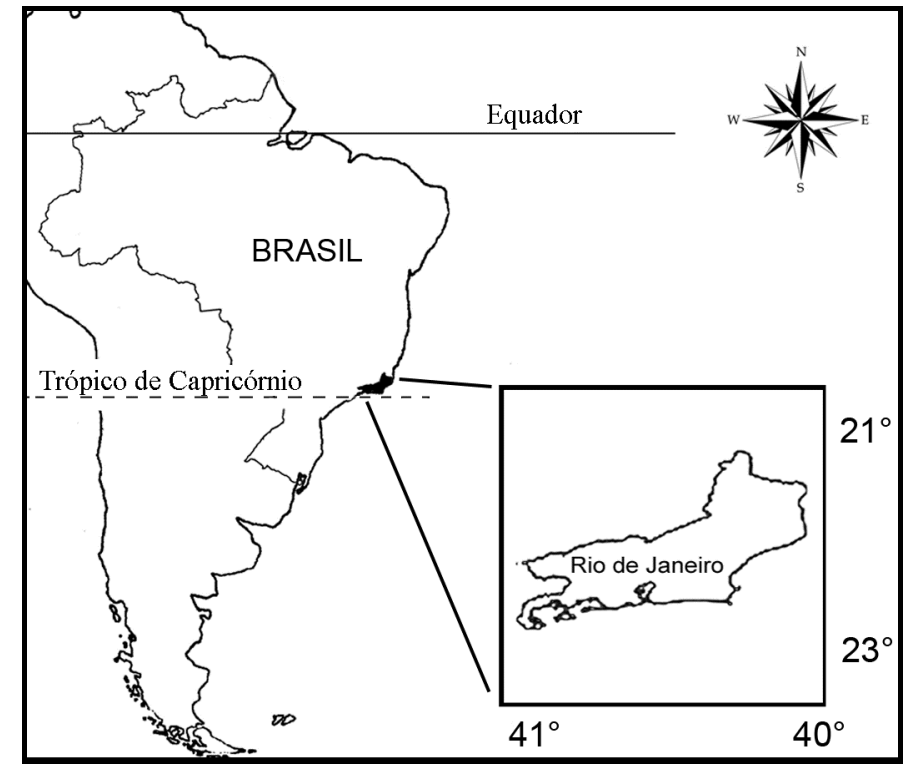

O Estado do Rio de Janeiro apresenta uma linha de costa que se estende por aproximadamente $850 \mathrm{~km}$, entrecortado por três baías (Baía de Guanabara, da Ilha Grande e de Sepetiba) e repleto de lagunas, áreas de restinga, brejos, mangues, costões rochosos e ilhas (cerca de 365 ilhas). Essas áreas apresentam características peculiares no que diz respeito a interesses de conservação.

O litoral do Estado do Rio de Janeiro tem seu limite norte na cidade de São

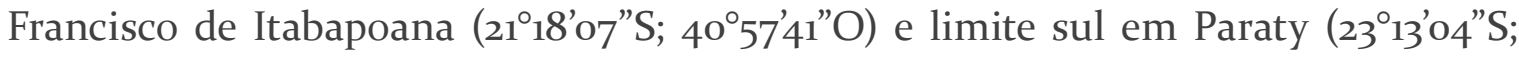
$\left.41^{\circ} 47^{\prime} 13^{\prime} \mathrm{O}\right)$. Vinte e seis municípios do Rio de Janeiro são litorâneos e são divididos em quatro regiões, com suas respectivas cidades, a saber:

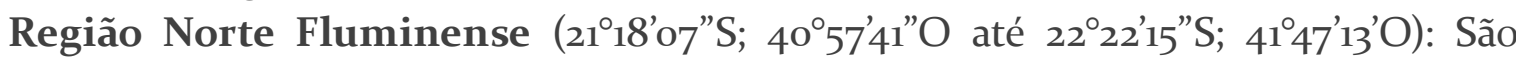
Francisco de Itabapoana, São João da Barra, Campos dos Goytacazes, Quissamã, Carapebus e Macaé.

Região das Baixadas Litorâneas ( $22^{\circ} 31^{\prime} 37^{\prime \prime} \mathrm{S}, 4^{\circ}{ }^{\circ} 6^{\prime} 42^{\prime} \mathrm{O}$ até $\left.22^{\circ} 55^{\prime} 12^{\prime \prime} \mathrm{S} ; 4^{\circ} 30^{\prime} 37^{\prime \prime} \mathrm{O}\right)$ : Rio das Ostras, Casimiro de Abreu, Cabo Frio, Armação de Búzios, Arraial do Cabo, Araruama e Saquarema.

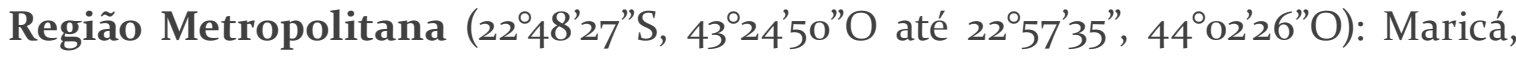
Niterói, São Gonçalo, Itaboraí, Guapimirim, Magé, Duque de Caxias, Rio de Janeiro, Itaguaí e Mangaratiba.

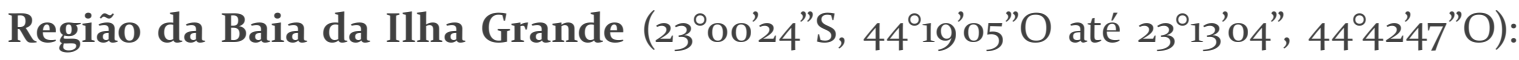
Angra dos Reis e Paraty.

As águas do litoral fluminense apresentam salinidade entre 33 e 36, e temperaturas médias variando de $16^{\circ} \mathrm{C}$ no verão a $22^{\circ} \mathrm{C}$ no inverno. $\mathrm{O}$ litoral pode ser dividido em duas regiões: uma de Campos a Cabo Frio, caracterizando o litoral Norte, e outra de Cabo Frio a Paraty, caracterizando o litoral Sul.

A plataforma continental do litoral fluminense é banhada por água de uma massa tropical e outra costeira. No litoral Norte, ela se estende até $80 \mathrm{~km}$ da costa 
em Campos e até $50 \mathrm{~km}$ em Cabo Frio e tem profundidades entre 6o e 100 metros, ao passo que no litoral Sul sua profundidade varia de 120 a 180 metros.

O fenômeno da ressurgência, que ocorre na região de Cabo Frio e Arraial do Cabo durante o verão, influencia tanto o litoral Norte quanto o litoral Sul, fenômeno este que determina o padrão de distribuição e abundância de algumas espécies. Esse fenômeno proporciona a diminuição da temperatura da água, o aumento da oferta de nutrientes e da produtividade primária. Além disso, a presença de estuários nessa região, principalmente os dos rios Paraíba do Sul, São João e Macaé, também contribui para um ambiente rico em nutrientes.

Neste Estado em especial, a composição da fauna de peixes é influenciada pelas correntes do Brasil ao norte, e das Malvinas ao sul. Em termos zoogeográficos, o Rio de Janeiro apresenta fauna de transição com elementos populacionais das Províncias Caribenha e Argentina (Menni \& Stehmann, 200o). Caracteriza-se por apresentar fauna de peixes com poucas espécies endêmicas, representando o limite sul de espécies tropicais e norte de formas temperadas.

\section{LISTA DE CLASSIFICAÇÃO DAS ESPÉCIES DE PEIXES CARTILAGINOSOS DO ESTADO DO RIO DE JANEIRO, BRASIL}

\section{TUBARÕES}

\section{Ordem HEXANCHIFORMES}

Família Hexanchidae Gray, 1851

Gênero Hexanchus Rafinesque, 1810

Hexanchus griseus (Bonnaterre, 1788)

Gênero Heptranchias Rafinesque, 1810

Heptranchias perlo (Bonnaterre, 1788)

Gênero Notorynchus Ayres, 1855

Notorynchus cepedianus (Péron, 1807)

Ordem SQUALIFORMES

Família Echinorhinidae Gill, 1862

Gênero Echinorhinus Blainville, 1816

Echinorhinus brucus (Bonnaterre, 1788)

Família Dalatiidae Gray, 1851

Gênero Squaliolus Smith \& Radcliffe, 1912

Squaliolus laticaudus Smith \& Radcliffe, 1912

Gênero Isistius Gill, 1865

Isistius brasiliensis (Quoy \& Gaimard, 1824)

Família Squalidae

Gênero Cirrhigaleus Tanaka, 1912

Cirrhigaleus asper (Merret, 1973)

Gênero Squalus Linnaeus, 1758 
Squalus acanthias Linnaeus, 1758

Squalus albicaudus Viana, Carvalho \& Gomes, 2016

Squalus lobularis Viana, Carvalho \& Gomes, 2016

Família Somniosidae Jordan, 1888

Gênero Centroscymnus Bocage \& Capello, 1864

Centroscymnus coelolepis Bocage \& Capello, 1864

Centroscymnus owstoni Garman, 1906

Gênero Zameus Jordan \& Fowler, 1903

Zameus squamulosus (Günther, 1877)

Gênero Somniosus Le Sueur, 1818

Somniosus antarcticus Whitley, 1939

Família Etmopteridae Fowler, 1934

Gênero Etmopterus Rafinesque, 1810

Etmopterus bigelowi Shirai \& Tachikawa, 1993

Etmopterus lucifer Jordan \& Snyder, 1902

Ordem SQUATINIFORMES

Família Squatinidae Bonaparte, 1838

Gênero Squatina Dumeril, 1806

Squatina guggenheim Marini, 1936

Squatina occulta Vooren \& da Silva, 1991

Squatina varii Vaz \& Carvalho, 2018

Ordem LAMNIFORMES

Família Megachasmidae Taylor, Compagno \& Struhsaker, 1983

Gênero Megachasma Taylor, Compagno \& Struhsaker, 1983

Megachasma pelagios Taylor, Compagno \& Struhsaker, 1983

Família Alopiidae Bonaparte, 1838

Gênero Alopias Rafinesque, 1810

Alopias superciliosus Lowe, 1839

Alopias vulpinus (Bonnaterre, 1788)

Família Carchariiidae Müller and Henle, 1838

Gênero Carcharias Rafinesque, 1810

Carcharias taurus Rafinesque, 1810

Família Pseudocarchariidae Compagno, 1973

Gênero Pseudocarcharias Cadenat, 1963

Pseudocarcharias kamoharai (Matsubara, 1936)

Família Cetorhinidae Gill, 1862

Gênero Cetorhinus Blainville, 1816

Cetorhinus maximus (Gunnerus, 1765)

Família Lamnidae Müller \& Henle, 1838

Gênero Carcharodon Smith, 1838

Carcharodon carcharias (Linnaeus, 1758)

Gênero Lamna Cuvier, 1816

Lamna nasus (Bonaterre, 1788) 
Gênero Isurus Rafinesque, 1810

Isurus oxyrinchus Rafinesque, 1810

Isurus paucus Guitart Manday, 1966

Família Mitsukurinidae Jordan, 1898

Gênero Mitsukurina Jordan, 1898

Mitsukurina owstoni Jordan, 1898

Ordem ORECTOLOBIFORMES

Família Ginglymostomatidae Gill, 1862

Gênero Ginglymostoma Müller \& Henle, 1837

Ginglymostoma cirratum (Bonaterre, 1788)

Família Rhincodontidae Müller \& Henle, 1839

Gênero Rhincodon Smith, 1828

Rhincodon typus Smith, 1828

Ordem CARCHARHINIFORMES

Família Scyliorhinidae Gill, 1862

Gênero Scyliorhinus Blainville, 1816

Scyliorhinus ugoi Soares, Gadig \& Gomes, 2015

Scyliorhinus haeckelii (Ribeiro, 1907)

Scyliorhinus cabofriensis Soares, Gomes \& Carvalho, 2016

Gênero Apristurus Garman, 1913

Apristurus parvipinnis Springer \& Heemstra, 1979

Apristurus profundorum (Goode \& Bean, 1896)

Gênero Schroederichthys Springer, 1966

Schroederichthys saurisqualus Soto, 2001

Gênero Parmaturus Garman, 1906

Parmaturus angelae Soares, Carvalho, Schwingel \& Gadig, 2019

Família Triakidae Gray, 1851

Gênero Galeorhinus Blainville, 1816

Galeorhinus galeus (Linnaeus, 1758)

Gênero Mustelus Linck, 1790

Mustelus higmani Springer \& Lowe, 1963

Mustelus schmitti Springer, 1940

Mustelus norrisi Springer, 1940

Mustelus canis (Mitchell, 1815)

Família Carcharhinidae Jordan \& Evermann, 1896

Gênero Galeocerdo Müller \& Henle, 1837

Galeocerdo cuvier (Péron \& Lesueur, 1822)

Gênero Prionace Cantor, 1849

Prionace glauca (Linnaeus, 1758)

Gênero Negaprion Whitley, 1940

Negaprion brevirostris (Poey, 1868)

Gênero Rhizoprionodon Whitley, 1929

Rhizoprionodon porosus (Poey, 1861) 
Rhizoprionodon lalandii (Valenciennes, 1839)

Gênero Carcharhinus Blainville, 1816

Carcharhinus longimanus (Poey, 1861)

Carcharhinus porosus (Ranzani, 1839)

Carcharhinus limbatus (Valenciennes, 1839)

Carcharhinus brevipinna (Valenciennes, 1839)

Carcharhinus acronotus (Poey, 1860)

Carcharhinus obscurus (Lesueur, 1818)

Carcharhinus plumbeus (Nardo, 1827)

Carcharhinus leucas (Valenciennes, 1839)

Carcharhinus signatus (Poey, 1868)

Carcharhinus falciformis (Bibron, 1839)

Carcharhinus brachyurus (Günther, 1870)

Carcharhinus perezii (Poey, 1876)

Família Sphyrnidae Gill, 1872

Gênero Sphyrna Rafinesque, 1810

Sphyrna tiburo (Linnaeus, 1758)

Sphyrna tudes (Valenciennes, 1822)

Sphyrna media Springer, 1940

Sphyrna zygaena (Linnaeus, 1758)

Sphyrna mokarran (Rüppell, 1837)

Sphyrna lewini (Griffith \& Smith, 1834)

\section{RAIAS}

\section{Ordem RHINOPRISTIFORMES}

Família Pristidae Bonaparte, 1838

Gênero Pristis Kinck, 1790

Pristis pectinata Latham, 1794

Pristis pristis (Linnaeus, 1758)

Família Rhinobatidae Müller \& Henle, 1837

Gênero Pseudobatos Last, Serét \& Naylor, 2016

Pseudobatos horkelii (Müller \& Henle, 1841)

Pseudobatos percellens (Walbaum, 1792)

Família Trygonorhinidae Müller \& Henle, 1838

Gênero Zapteryx Jordan \& Gilbert, 1880

Zapteryx brevirostris (Müller \& Henle, 1841)

Ordem TORPEDINIFORMES

Família Torpedinidae

Gênero Tetronarce

Tetronarce puelcha (Lahille, 1926)

Família Narcinidae Gill, 1862

Gênero Narcine Henle, 1834 
Narcine brasiliensis (von Olfers, 1831)

Ordem RAJIFORMES

Família Gurgesiellidae De Buen, 1959

Gênero Gurgesiella De Buen, 1959

Gurgesiella dorsalifera McEachran \& Compagno, 1980

Família Rajidae Blainville, 1816

Gênero Dipturus Rafinesque, 1810

Dipturus mennii Gomes \& Paragó, 2011

Gênero Rajella Stehmann, 1970

Rajella sadowskii (Krefft \& Stehmann, 1974)

Gênero Amblyraja Malm, 1877

Amblyraja frerichsi (Krefft, 1968)

Gênero Malacoraja Stehmann, 1970

Malacoraja obscura Carvalho, Gomes \& Gadig, 2005

Família Arhynchobatidae McEachran \& Dunn, 1998

Gênero Atlantoraja Menni, 1972

Atlantoraja castelnaui (Ribeiro, 1907)

Atlantoraja platana (Günther, 1880)

Atlantoraja cyclophora (Regan, 1903)

Gênero Rioraja Whitley, 1939

Rioraja agassizi (Müller \& Henle, 1841)

Gênero Bathyraja Ishiyama, 1958

Bathyraja schroederi (Krefft, 1968)

Gênero Psammobatis Günther, 1870

Psammobatis extenta (Garman, 1913)

Psammobatis lentiginosa McEachran, 1983

Psammobatis rutrum Jordan, 1891

Gênero Sympterygia Müller \& Henle, 1837

Sympterygia bonapartii Müller \& Henle, 1841

Sympterygia acuta Garman, 1877

Ordem MYLIOBATIFORMES

Família Gymnuridae Fowler, 1934

Gênero Gymnura Kuhl, 1823

Gymnura altavela (Linnaeus, 1758)

Gymnura micrura (Bloch \& Schneider, 1801)

Família Dasyatidae Jordan \& Gilbert, 1879

Gênero Dasyatis Rafinesque, 1810

Dasyatis hypostigma Santos \& Carvalho, 2004

Gênero Bathystoshia Whitleym, 1933

Bathystoshia centroura (Mitchill, 1815)

Gênero Hypanus Rafinesque, 1818

Hypanus americanus (Hidelbrand \& Schroeder, 1928)

Hypanus guttatus (Bloch \& Schneider, 1801) 
Gênero Pteroplatytrygon Fowler, 1910

Pteroplatytrygon violacea (Bonaparte, 1832)

Família Mobulidae Gill, 1893

Gênero Mobula (Rafinesque, 1810)

Mobula birostris (Walbaum, 1798)

Mobula mobular (Bonnaterre, 1788)

Mobula tarapacana (Philippi, 1892)

Mobula hypostoma (Bancroft, 1831)

Mobula thurstoni (Lloyd, 1908)

Família Rhinopteridae Jordan \& Evermann, 1896

Gênero Rhinoptera Kuhl, 1829

Rhinoptera bonasus (Mitchill, 1815)

Rhinoptera brasiliensis (Müller, 1836)

Família Myliobatidae Bonaparte, 1835

Gênero Myliobatis Cuvier, 1816

Myliobatis freminvillei Lesueur, 1824

Myliobatis goodei Garman, 1885

Família Aetobatidae Agassiz, 1858

Gênero Aetobatus Blainville, 1816

Aetobatus narinari (Euphrasen, 1790)

QUIMERAS

Ordem CHIMAERIFORMES

Família Rhinochimaeridae Garman, 1901

Gênero Rhinochimaera Garman, 1901

Rhinochimaera atlantica Holt \& Byrne, 1909

Família Callorhynchidae Garman, 1901

Gênero Callorhinchus Lacépède, 1798

Callorhinchus callorhynchus (Linnaeus, 1758)

Família Chimaeridae Bonaparte, 1831

Gênero Hydrolagus Gill, 1862

Hydrolagus alberti Bigelow \& Schroeder, 1951

Hydrolagus matallanasi Soto \& Vooren, 2004

\section{CHAVE PARA A IDENTIFICAÇÃO DAS SUBCLASSES DE CHONDRICHTHYES PRESENTES NO RIO DE JANEIRO}

1a. Cinco a sete aberturas branquiais; espinho anterior à primeira nadadeira dorsal, quando presente, não dobrável; dentes individualizados ou pavimentosos; pele com dentículos dérmicos (exceto algumas raias).

Elasmobranchii 
1b. Uma abertura branquial; espinho anterior à primeira nadadeira dorsal sempre presente e dobrável; dentes em placas; sem dentículos dérmicos.

.Holocephali

\section{OS TUBARÕES DO ESTADO RIO DE JANEIRO}

\section{Chave para identificação das ordens de tubarões}

1a. Nadadeira anal ausente (Fig. 2, seta)

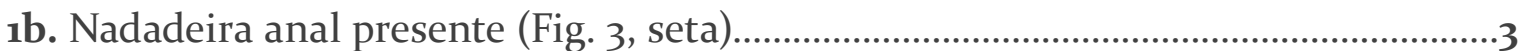

2a. Corpo achatado dorso-ventralmente (Fig. 4, seta)...................SQUATINIFORMES

2b. Corpo fusiforme (Fig. 5, seta)......................................................SQUALIFORMES

3a. Duas nadadeiras dorsais presentes (Fig. 6, seta A); cinco pares de fendas branquiais (Fig. 6)............................................................................................4 3b. Uma nadadeira dorsal presente (Fig. 7, seta A); seis ou sete pares de fendas branquiais (Fig. 7).

HEXANCHIFORMES

4a. Barbilhões nasais presentes (Fig. 8, seta); olhos posteriores à linha vertical traçada na origem do canto da boca (Fig. 8).

.ORECTOLOBIFORMES

4b. Barbilhões nasais ausentes; olhos anteriores à linha vertical traçada na origem do canto da boca (Fig. 9)

5a. Membranas nictitantes ausentes (Fig.10, seta).

.LAMNIFORMES

5b. Membranas nictitantes (rudimentares ou desenvolvidas) presentes (Fig. 11, seta)

CARCHARHINIFORMES

\section{ORDEM HEXANCHIFORMES}

Tubarões com apenas uma nadadeira dorsal, sem espinho; seis ou sete pares de fendas branquiais. Dentes superiores e inferiores bem diferenciados. Os dentes superiores próximos à sínfise são afilados, com uma cúspide; os dentes mais laterais apresentam cúspides secundárias, e os dentes inferiores são largos, apresentando várias cúspides secundárias do lado comissural (no canto da boca) (Fig. 12). Na costa do Estado do Rio de Janeiro, essa ordem está representada pela família Hexanchidae.

\section{Família HEXANCHIDAE}

Os representantes dessa família apresentam seis ou sete fendas branquiais e uma única nadadeira dorsal anterior à nadadeira pélvica. Sua reprodução se dá por 
viviparidade placentotrófica, isto é, o embrião se desenvolve dentro do útero materno às custas das reservas vitelínicas utilizadas até o nascimento.

No Brasil, as espécies são mais frequentes na região Sul e Sudeste, onde Notorynchus cepedianus é, aparentemente, mais costeiro, enquanto Hexanchus griseus e Heptranchias perlo são comuns em regiões mais afastadas da costa. No Rio de Janeiro, ocorrem três gêneros e três espécies: Hexanchus griseus, Heptranchias perlo e Notorynchus cepedianus.

\section{Chave de identificação para os Gêneros da Família Hexanchidae}

1a. Seis pares de fendas branquiais (Fig. 13)

Hexanchus

1b. Sete pares de fendas branquiais (Fig. 14)

2

2a. Cabeça com focinho pontiagudo (Figs. 15 e 16); corpo rígido, sem manchas escuras na superfície dorsal (Fig. 15); diâmetro horizontal do olho igual à distância internasal, cabendo aproximadamente uma vez nesta distância (Fig. 16, setas) Heptranchias

2b. Cabeça com focinho arredondado (Figs. 17 e 18); corpo notavelmente flexível, com pequenas manchas escuras na superfície dorsal (Fig. 17); diâmetro horizontal do olho visivelmente menor que a distância internasal, cabendo aproximadamente 2,5 vezes nesta distância (Fig. 18, setas) Notorynchus

\section{Gênero Hexanchus}

Seus representantes possuem seis pares de fendas branquiais. São conhecidas três espécies: H. griseus, H. vitulus Springer \& Waller, 1969 e H. nakamurai (Teng, 1962). Apenas a primeira ocorre no Brasil e no Rio de Janeiro.

Hexanchus griseus (Bonnaterre, 1788) (Fig. 19)

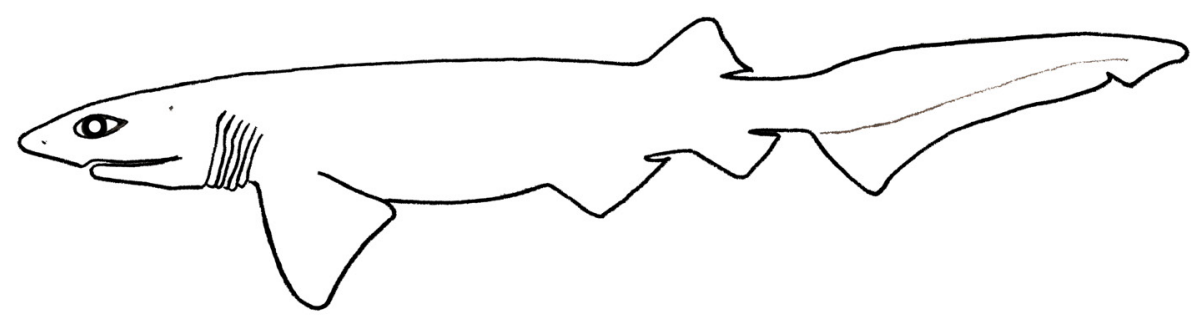

Nome popular: tubarão-de-seis-guelras.

Caracteres distintivos: cabeça com focinho arredondado; boca ampla e arqueada; seis pares de fendas branquiais anteriores à origem das nadadeiras peitorais; origem da nadadeira sobre ou posterior à vertical traçada na inserção das nadadeiras pélvicas; 
pedúnculo caudal curto, sendo a distância entre a inserção da nadadeira dorsal e a origem do lobo superior da caudal igual ou pouco maior que o comprimento da base da nadadeira dorsal; nadadeira caudal com lobo superior longo, cerca de três vezes o comprimento do lobo inferior e com lobo terminal bem definido. Coloração castanha escura uniforme no dorso e na lateral do corpo; ventre um pouco mais claro.

Tamanho: máximo 4,8 m de CT; os neonato medem aproximadamente $70 \mathrm{~cm}$ de CT. Distribuição, Hábitos e Biologia: distribui-se por todos os oceanos, desde águas temperadas a tropicais. Na costa brasileira, registrada no Nordeste (incluindo Arquipélago Fernando de Noronha) e no Sul, em Santa Catarina e Rio Grande do Sul em profundidades entre 300 - $600 \mathrm{~m}$. Indivíduos jovens vivem em águas mais rasas e próximas à costa, enquanto os adultos são encontrados em águas profundas de até cerca de $2.000 \mathrm{~m}$. Podem parir entre 22 e 108 filhotes por vez (é um dos tubarões mais prolíficos). Alimentam-se de uma ampla variedade de organismos marinhos como crustáceos, peixes ósseos, outros tubarões, raias e quimeras.

Observação: Essa espécie tem ampla ocorrência ao longo da costa brasileira, por isso, apesar de não ter sido registrada nos levantamentos do presente artigo, foi incluída pela possibilidade de ocorrer na região. Existe também o registro em coleção ictiológica de uma arcada dentaria de um indivíduo macho (UERJ 901), coletado "entre as Regiões Sul e Sudeste".

\section{Gênero Heptranchias}

Caracteriza-se por apresentar sete pares de fendas branquiais; cabeça com focinho pontiagudo; corpo rígido sem manchas escuras na superfície dorsal; diâmetro horizontal do olho igual à distância internasal, cabendo aproximadamente uma vez nesta distância. Há apenas uma espécie conhecida no mundo, Heptranchias perlo, que é encontrada em praticamente todo o litoral brasileiro.

Heptranchias perlo (Bonnaterre, 1788) (Fig. 20)

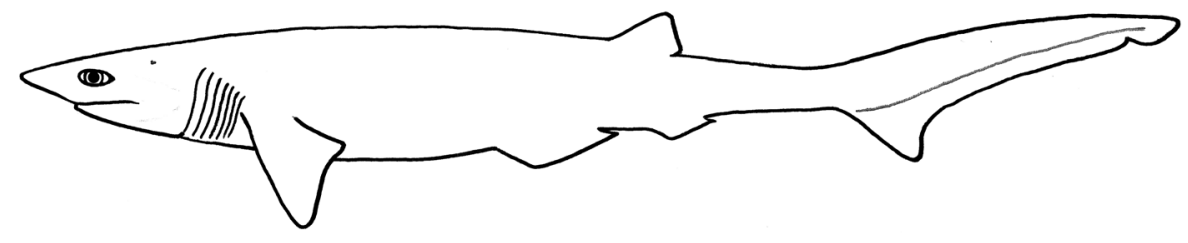

Nome popular: tubarão-de-sete-guelras.

Caracteres distintivos: apresenta corpo afinado e rígido; cabeça estreita e pontiaguda; olhos bem desenvolvidos, com seu diâmetro horizontal igual à distância internasal; boca muito estreita e arqueada; sete pares de fendas branquiais anteriores à origem das nadadeiras peitorais; origem da única nadadeira dorsal acima ou posterior à vertical traçada na inserção das nadadeiras pélvicas; pedúnculo caudal 
longo, com a distância entre a inserção da nadadeira dorsal e a origem do lobo superior da nadadeira caudal mais de duas vezes o comprimento da base da nadadeira dorsal; nadadeira caudal com lobo superior longo, atingindo cerca de três vezes o comprimento do lobo inferior; possui lobo terminal, que é bem definido. Coloração castanha clara, sem manchas ou pontuações, mas apenas com manchas enegrecidas na ponta da nadadeira dorsal e no lobo superior da nadadeira caudal (fracamente ou não evidenciada nos adultos mas bem evidente nos juvenis).

Tamanho: CT máximo reportado de 1,37 m, e neonatos por volta de $25 \mathrm{~cm}$.

Distribuição, Hábitos e Biologia: Espécie amplamente distribuída em águas tropicais e temperadas. No Rio de Janeiro, foi registrada pela primeira vez próxima ao Cabo de São Tomé ( $22^{\circ} 10^{\prime} \mathrm{S}$ e $\left.39^{\circ} 54^{\prime} \mathrm{W}\right)$. Espécie bentônica vivendo em profundidades entre 27 e $1.000 \mathrm{~m}$. Dá a luz de nove a 20 filhotes por vez. Moluscos (lulas) e peixes ósseos fazem parte de sua dieta.

\section{Gênero Notorynchus}

Seus representantes possuem cabeça com focinho arredondado; corpo flexível com pequenas manchas escuras na superfície dorsal; diâmetro horizontal do olho notavelmente menor do que a distância internasal, cabendo aproximadamente 2,5 vezes nesta distância. Notorynchus cepedianus é a única espécie conhecida no mundo.

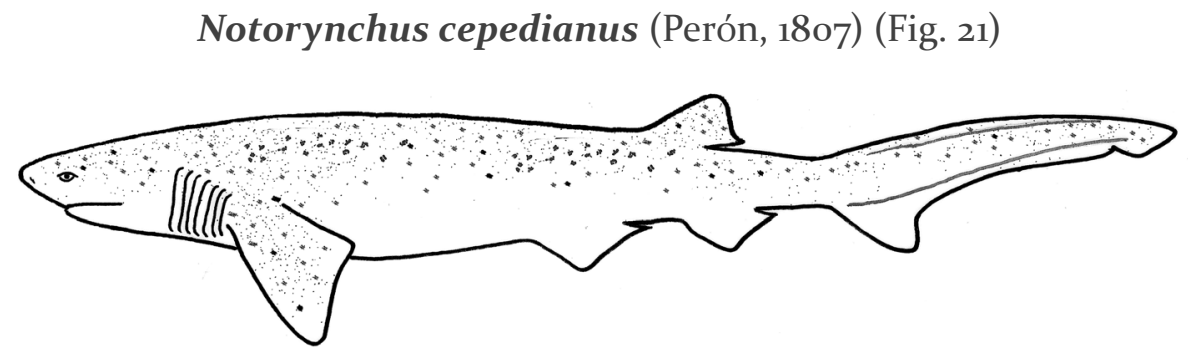

Nome popular: cação-bruxa.

Caracteres distintivos: tubarão de corpo mole e flexível; cabeça larga e levemente comprimida, com focinho arredondado; boca ampla e arqueada; sete pares de fendas branquiais anteriores à origem das nadadeiras peitorais; origem da única nadadeira dorsal posterior à inserção das nadadeiras pélvicas; pedúnculo caudal curto, sendo a distância entre a inserção da nadadeira dorsal e a origem do lobo superior da nadadeira caudal aproximadamente igual ao comprimento da base da nadadeira dorsal; nadadeira caudal com lobo superior longo, seu comprimento aproximadamente igual a quatro vezes o comprimento do lobo inferior; possui o lobo subterminal bem definido. Coloração castanha escura com numerosas pontuações negras, mas sem as pontas enegrecidas na nadadeira dorsal e no lobo superior da caudal. 
Tamanho: CT de aproximadamente $2,9 \mathrm{~m}$; comprimento ao nascer por volta de 45 a $53 \mathrm{~cm}$ de $\mathrm{CT}$.

Distribuição, Hábitos e Biologia: amplamente distribuída em águas temperadas. No Brasil, tem seu limite norte de distribuição no Estado do Rio de Janeiro, o que sugere a sua preferência por águas frias. Possui hábitos bentônicos e/ou neríticos. Vive em águas rasas próximas à costa; os indivíduos maiores preferem águas mais profundas e afastadas. Dá a luz a cerca de 82 filhotes por ninhada. Alimenta-se de peixes ósseos, de outros tubarões, raias e também de carniça.

\section{ORDEM SQUALIFORMES}

Os tubarões desta ordem apresentam duas nadadeiras dorsais precedidas ou não por um espinho; espiráculos presentes; cinco pares de fendas branquiais anteriores à nadadeira peitoral. A nadadeira anal é ausente.

Essa é a segunda maior ordem de tubarões e é representada por um variado grupo de espécies. Seus representantes podem ser diminutos, como o menor tubarão existente, Mollisquama mississipiensis Grace, Doosey, Denton, Naylor, Bart Jr. \& Maisey, 2019, tendo com o único exemplar uma fêmea imatura, medindo $142 \mathrm{~mm}$ de CT, ou ter espécies que chegam até sete metros de comprimento, como alguns exemplares do gênero Somniosus.

O hábito demersal da maioria das espécies dessa ordem dificulta a captura desses animais, de maneira que podem ocorrer espécies ainda desconhecidas pela ciência na área em questão. Compreende um total mundial de sete famílias, 22 gêneros e cerca de 98 espécies, preferencialmente em águas profundas, a mais de 200 metros. No Rio de Janeiro essa ordem é representada por cinco famílias, sete gêneros e 11 espécies.

\section{Chave para identificação das famílias da ordem Squaliformes}

$1 \mathbf{a}$ - Linha vertical traçada na origem da primeira nadadeira dorsal passa posterior à origem da nadadeira pélvica (Fig. 22, seta). ECHINORHINIDAE $\mathbf{1 b}$ - Linha vertical traçada na origem da primeira nadadeira dorsal passa anterior à

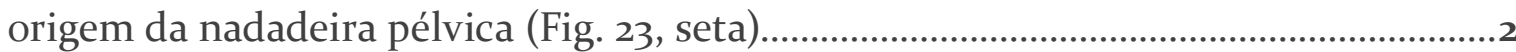
2a. Nadadeiras dorsais com espinhos sem sulcos; dentes superiores morfologicamente iguais aos dentes inferiores (Fig. 24); lóbulo caudal subterminal ausente

SQUALIDAE

2b. Nadadeiras dorsais com espinhos com sulcos quando presentes; dentes superiores morfologicamente diferentes dos dentes inferiores (Fig. 25); lóbulo caudal subterminal presente. 
3a. Dentes superiores com uma cúspide central e cúspides secundárias laterais; região ventral, flancos e cauda com manchas negras; órgãos luminosos (fotóforos) presentes.

ETMOPTERIDAE

3b. Dentes superiores com apenas uma cúspide; região ventral, flancos e cauda sem manchas negras; órgãos luminosos (fotóforos) ausentes.

4a. Cabeça moderadamente larga; focinho achatado; duas nadadeiras dorsais com ou sem espinhos (Fig. 26).

SOMNIOSIDAE

4b. Cabeça estreita; focinho cônico; espinhos nas nadadeiras dorsais ausentes (exceto Squaliolus) (Fig. 27).....

DALATIIDAE

\section{Família ECHINORHINIDAE}

Caracteriza-se por corpo coberto por dentículos dérmicos desenvolvidos, com cúspides agudas, agrupados ou não; pela primeira nadadeira dorsal recuada, com origem posterior à vertical traçada na origem das nadadeiras pélvicas, e pela ausência de espinho precedendo as nadadeiras dorsais. Essa família é composta por um único gênero (Echinorhinus).

\section{Gênero Echinorhinus}

Os dentículos dérmicos dessa espécie são bem protuberantes, dispostos agrupados ou não, e com bases estreladas ou arredondadas. Esse gênero possui duas espécies no mundo, mas apenas uma delas é encontrada em águas brasileiras: Echinorhinus brucus.

Echinorhinus brucus (Bonnaterre, 1788) (Fig. 28)

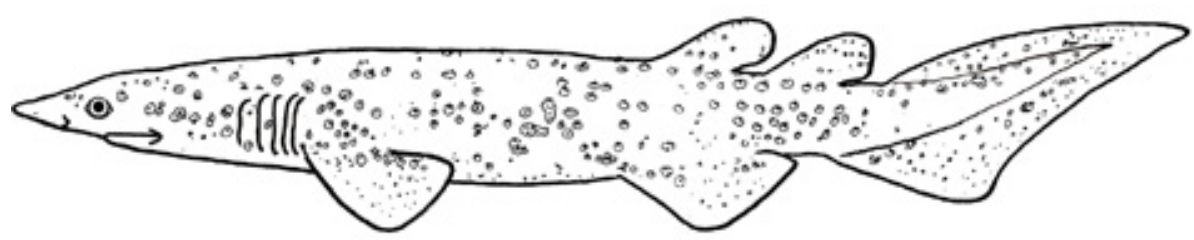

Nome popular: tubarão-espinhoso.

Caracteres distintivos: dentes superiores e inferiores semelhantes, apresentando uma cúspide principal e duas ou mais cúspides secundárias nos adultos, e apenas uma nos juvenis; nadadeira caudal sem lobo subterminal; dentículos dérmicos protuberantes com bases arredondadas, agrupados e/ou fusionados. Coloração do corpo castanho escura com numerosas pontuações negras.

Tamanho: adultos atingem aproximadamente três metros de CT. 
Distribuição, Hábitos e Biologia: apresenta uma distribuição fragmentada em todos os oceanos, preferencialmente em águas profundas (até $900 \mathrm{~m}$ ), de águas temperadas ou tropicais, sobre a plataforma continental, insular ou em taludes. No Brasil é registrada para as regiões Sudeste e Sul, com ocorrência no Rio de Janeiro, Paraná e Rio Grande do Sul. Nascem mais de 82 filhotes por ninhada. Alimentam-se de crustáceos (caranguejos), peixes ósseos e pequenos tubarões.

\section{Família DALATIIDAE}

Origem da primeira nadadeira dorsal anterior à vertical traçada na origem das nadadeiras pélvicas; segunda nadadeira dorsal sem espinho; corpo não espinhoso, dentículos dérmicos truncados ou com uma cúspide (unicúspides) (Bigelow \& Schroeder, 1957). Com sete gêneros e um total de dez espécies no mundo, essa família é representada no Estado do Rio de Janeiro por dois gêneros (Squaliolus e Isistius).

\section{Chave para identificação dos gêneros da família Dalatiidae}

1a. Espinho da primeira nadadeira dorsal presente; origem da primeira nadadeira dorsal mais próxima da origem das nadadeiras peitorais, do que da origem das nadadeiras pélvicas (Fig. 29, setas); comprimento da base da primeira nadadeira dorsal cabendo aproximadamente a duas vezes no comprimento da base da segunda nadadeira dorsal; Não possui colar escuro ao redor da região branquial da cabeça. Squaliolus

1b. Espinho da primeira nadadeira dorsal ausente; origem da primeira nadadeira dorsal mais próxima da origem das nadadeiras pélvicas, que da inserção das nadadeiras peitorais (Fig. 30, setas); comprimento da base da segunda nadadeira dorsal aproximadamente igual ao comprimento da base da primeira nadadeira dorsal; apresenta um colar escuro ao redor da região branquial da cabeça.

Isistius

\section{Gênero Squaliolus}

Apresenta um espinho precedendo a primeira nadadeira dorsal; origem da primeira nadadeira dorsal mais próxima da inserção das nadadeiras peitorais que da origem das nadadeiras pélvicas; comprimento da base da segunda nadadeira dorsal cabendo aproximadamente duas vezes no comprimento da base da primeira nadadeira dorsal. Com duas espécies no mundo, esse gênero é representado em águas brasileiras e fluminenses por S. laticaudus. 
Squaliolus laticaudus Smith \& Radcliffe, 1912 (Fig. 31)

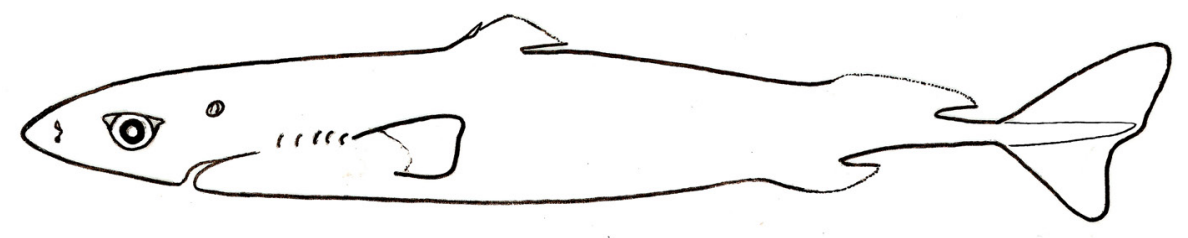

Nome Popular: tubarão-charuto.

Caracteres distintivos: dentes superiores e inferiores diferentes, sendo os dentes superiores pequenos com apenas uma cúspide; dentes inferiores muito maiores que os superiores, imbricados uns sobre os outros com forma de lâmina e com apenas uma cúspide; fendas branquiais de tamanhos iguais; nadadeiras peitorais com ápices levemente arredondados; pequeno espinho presente apenas na primeira nadadeira dorsal, seu ápice atingindo o meio da altura desta nadadeira. Coloração negra no corpo com as nadadeiras de margens claras.

Tamanho: CT máximo de aproximadamente $25 \mathrm{~cm}$ de CT para fêmeas e $22 \mathrm{~cm}$ de CT para machos; fêmeas se tornam maduras com cerca de 17-20 cm de CT, e machos, com $15 \mathrm{~cm}$ de CT.

Distribuição, Hábitos e Biologia: vive em regiões epipelágicas tropicais em todos os oceanos, na costa ou sobre o talude continental em profundidades de 200 a $500 \mathrm{~m}$. Recentemente espécimes foram capturados entre os Estados da Bahia e do Rio de Janeiro. Desenvolvimento embrionário presumivelmente por viviparidade lecitotrófica, sem informações sobre o número de filhotes por ninhada. Alimentamse de cefalópodes pelágicos (lulas pequenas) e peixes ósseos.

\section{Gênero Isistius}

Caracteres distintivos: ausência de espinhos precedendo as nadadeiras dorsais; origem da primeira nadadeira dorsal mais próxima da origem das nadadeiras pélvicas que da inserção das nadadeiras peitorais; comprimento da base da segunda nadadeira dorsal aproximadamente igual ao comprimento da base da primeira nadadeira dorsal. Há três espécies no mundo, e uma delas ocorre na costa do Estado do Rio de Janeiro: $I$. brasiliensis.

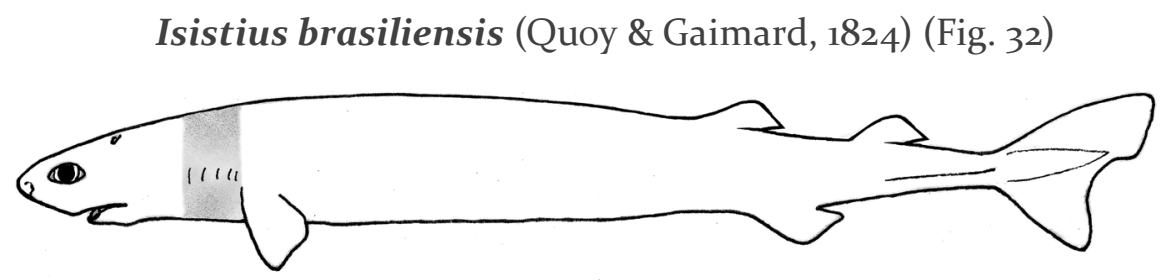


Nomes populares: tubarão-charuto, tubarão-piolho.

Caracteres distintivos: colar escuro ao redor da região branquial da cabeça presente; espaço interdorsal maior que duas vezes o comprimento da base da primeira nadadeira dorsal; nadadeiras pélvicas maiores que as nadadeiras dorsais. Coloração acinzentada, com uma faixa escura (como se fosse um colar) ao redor da região branquial.

Tamanho: CT de aproximadamente $50 \mathrm{~cm}$; machos e fêmeas se tornam maduros com cerca de 38 e $40 \mathrm{~cm}$ de CT, respectivamente.

Distribuição, Hábitos e Biologia: distribuição circuntropical epipelágica e batipelágica em regiões oceânicas; encontrados entre profundidades de 85 a 3.500 $\mathrm{m}$, aparentemente sobem à superfície durante a noite. No Brasil ocorrem nas costas do Sudeste e Sul. Desenvolvimento embrionário vivíparo lecitotrófico. Há registro de uma fêmea medindo 46,5 c m CT, carregando nove embriões bem desenvolvidos (cinco no útero direito e quatro no esquerdo). Alimentam-se de cefalópodes (lulas) e pequenos peixes ósseos. Esses pequenos tubarões costumam também atacar animais muito maiores do que eles (p.ex. grandes peixes ósseos, tubarões e cetáceos), deixando mutilações pequenas e circulares típicas no corpo das vítimas. Foi registrado um ataque desse tubarão a uma pessoa no Havaí, em 2011.

\section{Família SQUALIDAE}

Presença de espinhos precedendo as duas nadadeiras dorsais; dentes superiores de formato semelhante aos inferiores. Mundialmente representada por dois gêneros (Cirrhigaleus e Squalus), ambos presentes na costa do Rio de Janeiro

\section{Chave de identificação para os gêneros da família Squalidae}

1a. Segunda nadadeira dorsal quase tão grande quanto a primeira nadadeira dorsal (Fig. 33, setas A); sulco pré-caudal superior ausente ou vestigial (Fig. 33, seta B) Cirrhigaleus

1b. Nadadeiras dorsais de tamanhos diferentes, sendo a primeira nitidamente maior que a segunda (Fig. 34, seta A); sulco pré-caudal superior presente e bem demarcado (Fig. 34, seta B) Squalus

\section{Gênero Cirrhigaleus}

Caracteriza-se pela segunda nadadeira dorsal quase tão grande quanto a primeira nadadeira dorsal; sulco pré-caudal superior ausente ou vestigial. Apenas três espécies conhecidas no mundo: C. asper (Merrett 1973), C. barbifer Tanaka, 1912 
e C. australis White, Last \& Stevens, 2007. Esse gênero é representado na costa do Estado do Rio de Janeiro pela espécie Cirrhigaleus asper.

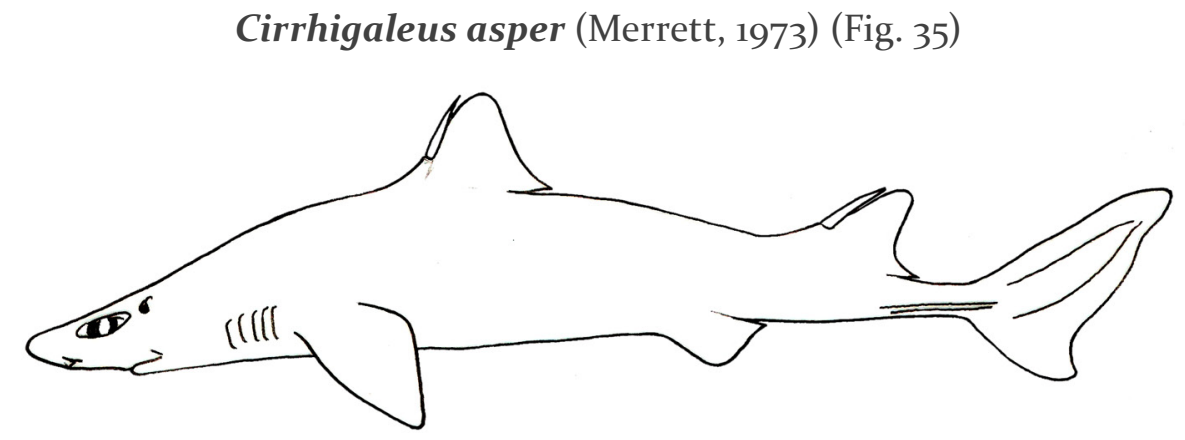

Nome popular: cação-bagre.

Caracteres distintivos: origem da primeira nadadeira dorsal posterior à vertical traçada na inserção das nadadeiras peitorais; segunda nadadeira dorsal quase tão grande quanto a primeira; sulco pré-caudal superior ausente ou vestigial. Coloração dorsal cinza a castanho claro, nadadeiras dorsais com margem posterior mais clara; ventre também mais claro.

Tamanho: comprimento total máximo nos adultos de aproximadamente 1,2 m; machos atingem a maturidade sexual com cerca de $85 \mathrm{~cm}$ de CT e as fêmeas, com cerca de $90 \mathrm{~cm}$ de CT. Nascem medindo entre 25 e $28 \mathrm{~cm}$ de CT.

Distribuição, Hábitos e Biologia: Ocorrem nos Oceanos Atlântico Ocidental e Índico Ocidental, com poucos registros no Oceano Pacífico. No Brasil, tem registros na costa Nordeste, Sudeste e Sul. Demersal em águas temperadas, entre 200 a $600 \mathrm{~m}$ de profundidade (o holótipo foi encontrado à $219 \mathrm{~m}$ ). Desenvolvimento embrionário por viviparidade lecitotrófica, com mais ou menos 22 filhotes por ninhada. Sua alimentação consiste em cefalópodes (lulas) e peixes ósseos.

\section{Gênero Squalus}

Caracteriza-se por possuir nadadeiras dorsais de tamanhos diferentes, sendo a primeira nadadeira dorsal nitidamente maior que a segunda nadadeira dorsal; sulco pré-caudal superior presente e bem demarcado; presença de crista lateral no pedúnculo caudal. O gênero Squalus apresenta muitos problemas taxonômicos.

Trabalhos antigos como Bigelow \& Schroeder (1948, 1957), Garrick (1960) e Bass et al (1976) dividem as espécies desse gênero em três grupos de espécies: o grupo acanthias ( $S$. acanthias, a única espécie facilmente identificada), o grupo megalops/ cubensis e o grupo blainvillei/mitsukurii.

Com a recente revisão do gênero Squalus do oceano Atlântico sul ocidental em Viana et al. (2016), esse arranjo em grupos de espécies caiu em desuso. Para a costa 
brasileira permanece registrada a espécie Squalus acanthias, porém com a descrição de quatro novas espécies: Squalus lobularis, S. bahiensis, S. quasimodo e S. albicaudus.

Na costa do Rio de Janeiro ocorrem as espécies Squalus acanthias, S. lobularis e $S$. albicaudus.

\section{Chave de identificação para as espécies do gênero Squalus}

1a. Origem do espinho da primeira nadadeira dorsal posterior à margem livre da nadadeira peitoral (Fig. 36, seta A); um lobo nasal na margem anterior da narina (Fig. 37); presença de manchas claras arredondadas na região dorsal do corpo (Fig. 36, seta B). Squalus acanthias

1b. Origem do espinho da primeira nadadeira dorsal anterior ou sobre a margem livre da nadadeira peitoral (Fig. 38, seta); dois lobos nasais na margem anterior da narina (Fig. 39); ausência de manchas mais claras arredondadas na região dorsal do corpo (Fig. 38)

2a. Margem interna da nadadeira peitoral pontiaguda (Fig. 40, seta A); dentículos dérmicos abaixo da primeira nadadeira dorsal unicuspidados (Fig. 41); distância da ponta do focinho até a margem interna da narina menor que a distância da margem interna da narina até a origem do sulco labial superior (Fig. 40, seta B)

S. albicaudus

2b. Margem interna da nadadeira peitoral arredondada (Fig. 42, seta A); dentículos dérmicos abaixo da primeira nadadeira dorsal tricuspidados (Fig. 43); distância da ponta do focinho até a margem interna da narina maior que a distância da margem interna da narina até a origem do sulco labial superior (Fig. 42, seta B).

S. lobularis

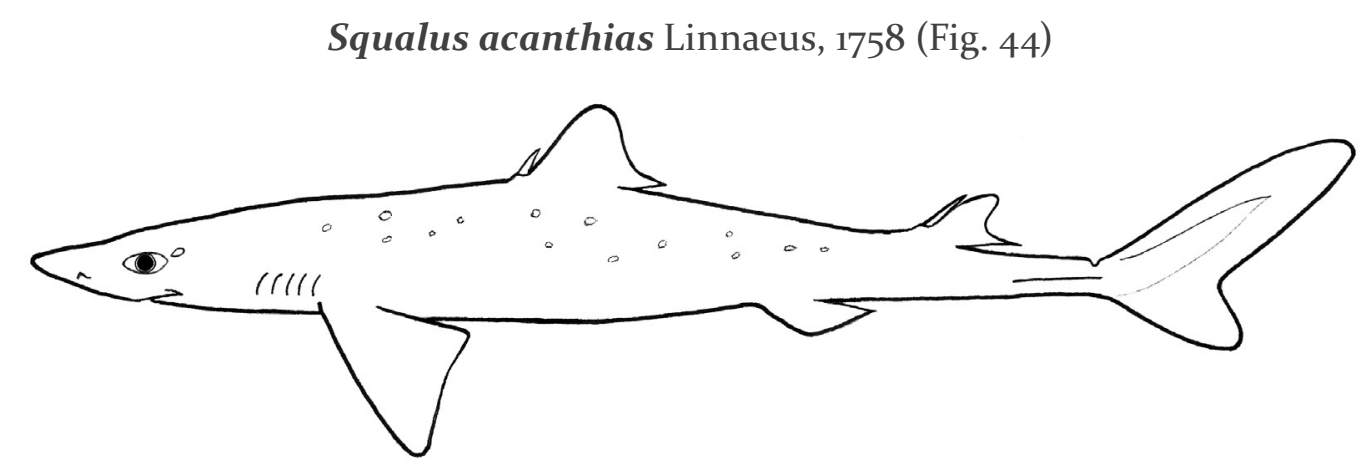

Nome popular: cação-bagre-espinhoso

Caracteres distintivos: Origem do espinho da primeira nadadeira dorsal posterior à vertical traçada sobre a margem livre da nadadeira peitoral; espinho da primeira nadadeira dorsal curto, longe de alcançar o ápice da primeira nadadeira dorsal; um lobo nasal na margem anterior da narina; presença de pontuações mais claras 
arredondadas na região dorsal. Essas pontuações mais claras são espalhadas até cerca da segunda nadadeira dorsal. Em alguns exemplares pode ocorrer junção dessas manchas. Essas pontuações também podem estar ausentes em poucos casos.

Tamanho: Comprimento total máximo encontrado nos representantes do atlântico sul ocidental foi $76 \mathrm{~cm}$; os machos são considerados adultos a partir de $59,5 \mathrm{~cm}$ de CT, e as fêmeas, com 53,5 cm de CT; neonatos são encontrados a partir $185 \mathrm{~cm}$ de CT. De um modo geral, esta espécie pode alcançar até $1,5 \mathrm{~cm}$ de CT.

Distribuição, Hábitos e Biologia: No Brasil, é registrada do Rio Grande do Sul até o Rio de Janeiro. É demersal, vivendo em profundidade que pode variar entre 50-400 m. Vivípara lecitotrófica, nascem até 20 filhotes por parto. Alimenta-se de invertebrados bentônicos e pequenos peixes ósseos.

Observações: Única espécie do gênero no Brasil de fácil identificação devido à coloração corpo, presença de um lobo nasal e posição da origem da primeira nadadeira dorsal, recuada em relação à inserção da nadadeira peitoral.

Squalus albicaudus Viana, Carvalho e Gomes, 2016 (Fig. 45)

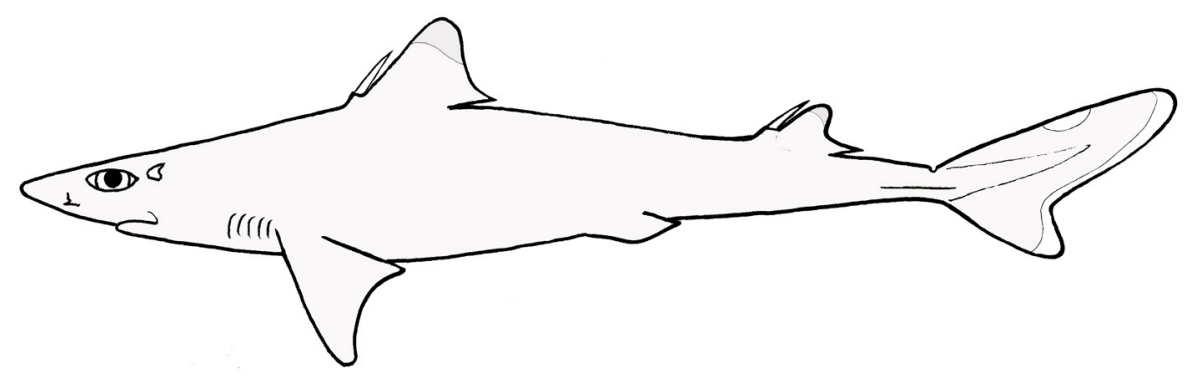

Nome popular: cação-bagre de cauda branca

Caracteres distintivos: distância da ponta do focinho ao canto interno da narina menor ou igual à distância do canto interno da narina ao início do sulco labial superior (Fig.40, seta B); margem livre da nadadeira peitoral pontiaguda (Fig. 40, seta A). Coloração do dorso varia de cinza a castanha uniforme; nadadeiras dorsais com mancha escura na margem anterior e na região apical; uma característica marcante na definição dessa espécie é uma mancha clara na margem dorso-caudal do lobo superior da nadadeira caudal (fig 46, seta A), como encontrada no holótipo. Entretanto nem sempre essa mancha está visível. Margem caudal posterior dos lobos superior e inferior mais clara, em faixa contínua (fig 46, seta B); nadadeiras peitorais com margem posterior clara; ventre esbranquiçado.

Tamanho: CT máximo $61 \mathrm{~cm}$; maturidade sexual nos machos ocorre entre 40 e 45 cm e, nas fêmeas, entre 54 e $61 \mathrm{~cm}$ de CT; nasce com cerca de $21 \mathrm{~cm}$ de CT.

Distribuição, Hábitos e Biologia: Registrada nas costas Nordeste e Sudeste do Brasil da Bahia até Ilha Vitória, São Paulo (exemplar depositado na Coleção do NUPEC número de tombo NUPEC 1354). É demersal, vivendo em profundidades entre 50-400 
m. Vivípara lecitotrófica, parindo entre um e quatro filhotes por gestação. Alimentase de invertebrados bentônicos e pequenos peixes ósseos.

Observações: Squalus albicaudus foi muitas vezes identificada como Squalus cubensis (e.g. Bigelow \& Schroeder, 1948; Figueiredo, 1977). Após a última revisão do gênero para o Oceano Atlântico Sul Ocidental, foi verificado que $S$. cubensis não ocorre na região Sudeste do Brasil.

Observações: Como a mancha característica na margem dorso-caudal do lobo superior da nadadeira caudal nem sempre é evidente, outros caracteres podem ser usados para separar essas espécies. Em Squalus cubensis, o ápice da primeira e da segunda nadadeiras dorsais têm manchas negras nos adultos, podendo atingir quase a metade inferior da nadadeira (Fig. 47, A e B, respectivamente). Nos juvenis há uma evidente mancha negra apenas na primeira nadadeira dorsal. Já em Squalus albicaudus, o ápice da primeira e da segunda nadadeiras dorsais pode ser escurecido (Fig. 48, A e B, respectivamente), mas nunca negra como em Squalus cubensis.

Outra diferenciação que pode ser útil na separação dessas espécies seria o posicionamento das nadadeiras pélvicas no corpo. Em S. albicaudus a origem da nadadeira pélvica é mais proxima da origem da segunda nadadeira dorsal (Fig. 49). Em $S$. cubensis a nadadeira pélvica tem sua origem em um ponto equidistante entre o ponto de origem da primeira e da segunda nadadeira dorsal (Fig. 50) (observação encontrada em Viana et al., 2016). Entretanto variações dessas medidas podem ser ontogenéticas ou mesmo intraespecíficas. Nas duas espécies a margem posterior da nadadeira caudal é mais clara. Squalus albicaudus, porém, difere de $S$. cubensis por, eventualmente, apresentar uma mancha mais clara na margem anterior do lobo superior da nadadeira caudal (Fig. 46, seta A).

Squalus lobularis Viana, Carvalho e Gomes, 2016 (Fig. 51)

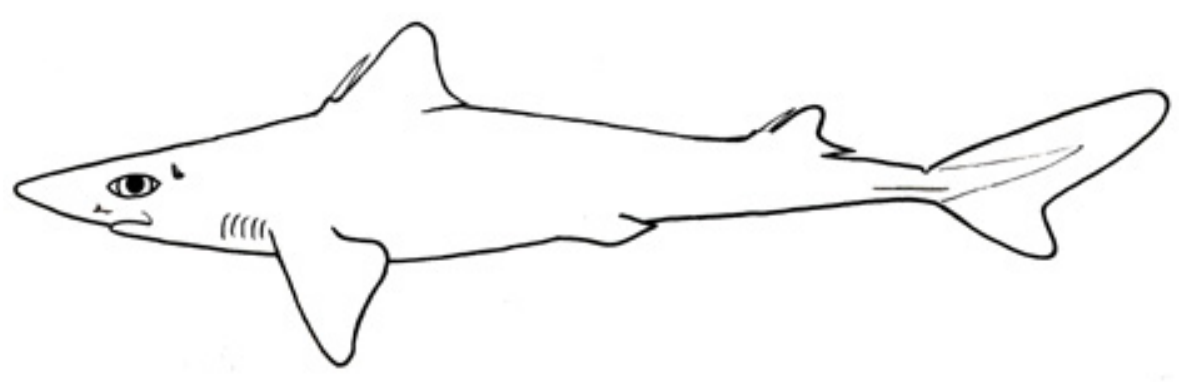

Nome popular: cação-bagre.

Caracteres distintivos: distância da ponta do focinho até a margem interna da narina maior que a distância da margem interna da narina até a origem do sulco labial superior (Fig. 42, seta B); margem interna da nadadeira peitoral arredondada (Fig. 42, seta A). Coloração do dorso varia de cinza a castanho uniforme; metade superior das nadadeiras dorsais e região central da margem dorso-caudal do lobo superior da caudal mais escura; ventre cinza claro, não contrastando muito com a coloração do dorso. 
Tamanho: atingem cerca de $72,5 \mathrm{~cm}$ de CT; machos e fêmeas são sexualmente maduros a partir de $60 \mathrm{~cm}$. Neonatos com tamanho aproximadamente de $23,5 \mathrm{~cm}$ de CT.

Distribuição, Hábitos e Biologia: No Brasil, essa espécie é registrada do Espírito Santo até o Rio Grande do Sul.

Ocorre também na Patagônia, Mar de Del Plata (Argentina) e Uruguai. É demersal, em profundidade variando entre 50-400 $\mathrm{m}$. Vivípara lecitotrófica, dá a luz de dois a nove filhotes por parto. Alimenta-se de invertebrados bentônicos e pequenos peixes ósseos.

Observação: No Brasil, essa espécie pode ser erroneamente identificada como Squalus mitsukurii ou S. blainvillei.

\section{Família SOMNIOSIDAE}

As espécies dessa família na costa do Rio de Janeiro são caracterizadas por apresentarem a cabeça larga, cônica ou achatada, e o focinho achatado. Espinho das nadadeiras dorsais reduzidos ou ausentes (ou espinhos internos, não sobressaindo na pele). Segunda nadadeira dorsal não falcada. Origem da segunda nadadeira dorsal posicionada atrás de uma reta vertical traçada da origem da axila da nadadeira peitoral. Compreende um total mundial de sete gêneros e cerca de 16 espécies. Até o momento são registrados para o Rio de Janeiro os gêneros Centroscymnus, Zameus e Somniosus, todos ocorrendo em águas profundas da região.

\section{Chave de identificação para os gêneros da família Somniosidae}

1a. Espinho anterior a cada nadadeira dorsal presente (Fig. 52)

1b. Espinho anterior a cada nadadeira dorsal ausente (Fig. 53) Somniosus 2a. Dentes inferiores com cúspides altas, mais ou menos eretas (Fig. 54), dentículos dérmicos com microranhuras transversais entres as cristas longitudinais (Fig. 55) Zameus

2b. Dentes inferiores com cúspides baixas, mais ou menos oblíquas (Fig. 56), dentículos dérmicos sem microranhuras transversais entres as cristas longitudinais (Fig. 57)......

Centroscymnus

\section{Gênero Centroscymnus}

É caracterizado por apresentar dentes superiores e inferiores de formatos diferentes; os dentes superiores têm forma de lança e os dentes inferiores possuem cúspide oblíqua; exibem espinhos em ambas as nadadeiras dorsais, em geral encobertos pelo 
tegumento. Há seis espécies no mundo, mas apenas duas registradas para a costa do Rio de Janeiro (C. coelolepis e $C$. owstoni).

\section{Chave de identificação para as espécies do gênero Centroscymnus}

1a. Focinho curto: comprimento pré-oral menor que a largura da boca (Fig. 58); primeira nadadeira dorsal não estendida anteriormente como uma crista dérmica; origem da primeira nadadeira dorsal posterior às nadadeiras peitorais (Fig. 59, seta A); a base da segunda nadadeira dorsal menor que a distância da inserção da segunda dorsal à origem do lobo superior da nadadeira caudal (Fig. 59, B)..............C. coelolepis 1b. Focinho longo: comprimento pré-oral igual à largura da boca (Fig. 6o); primeira nadadeira dorsal estendida anteriormente como uma crista dérmica; origem da primeira nadadeira dorsal sobre a base das nadadeiras peitorais (Fig. 61, seta A); a base da segunda nadadeira dorsal é maior que a distância da inserção da axila da segunda nadadeira dorsal à origem do lobo superior da nadadeira caudal (Fig. 61, B)...

\section{C. owstoni}

Centroscymnus coelolepis Bocage \& Capello, 1864 (Fig. 62)

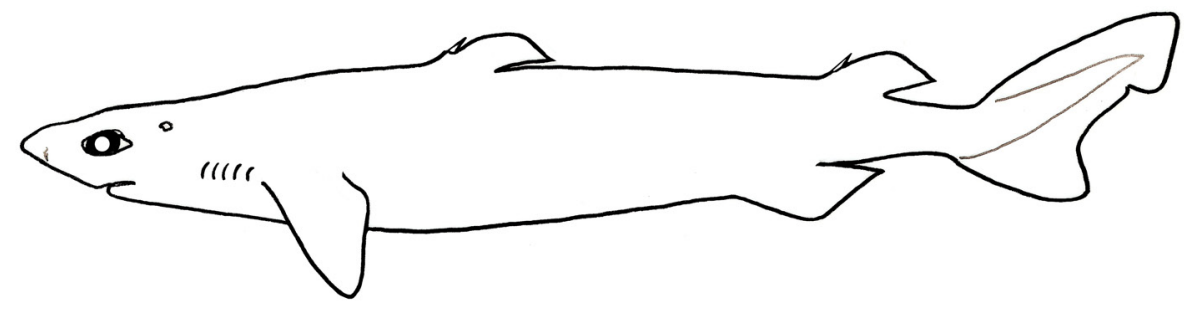

Nome popular: tubarão-português.

Caracteres distintivos: focinho arredondado e curto, com comprimento pré-oral menor que a largura da boca; primeira nadadeira dorsal não estendida anteriormente como uma quilha dérmica; sua origem posterior ao ápice da margem interna das nadadeiras peitorais; extremidade da margem livre da segunda nadadeira dorsal afastada da origem superior da nadadeira caudal; espinhos com ápices expostos nas duas nadadeiras dorsais. Coloração do dorso castanho escura uniforme; ventre freqüentemente com tons dourados.

Tamanho: CT máximo de aproximadamente 1,2 m; machos amadurecem em torno de 75 a 85 cm e fêmeas, com cerca de um metro de CT; nascem com cerca de $30 \mathrm{~cm}$. Distribuição, Hábitos e Biologia: distribui-se esparsamente nos Oceanos Atlântico e Índico Ocidental. No Brasil, foram capturados dois exemplares na costa entre o sul da Bahia e Sudeste. Provavelmente ocorre em grandes profundidades ao largo de toda a costa brasileira. Cabe citar um registro para região costeira do Rio de Janeiro, de uma fêmea neonata de 33,7 cm CT. De hábitos demersais, é uma das espécies de tubarões que ocorre em maiores profundidades, sendo encontrada entre 130 e 3.275 
$\mathrm{m}$, com a maioria dos registros abaixo dos $400 \mathrm{~m}$. Vivípara lecitotrófica, nascendo de oito a 29 filhotes por parto. Alimenta-se de moluscos (cefalópodes), pequenos peixes ósseos, eventualmente de outros elasmobrânquios e carcaças de cetáceos.

Centroscymnus owstoni Garman, 1906 (Fig. 63)

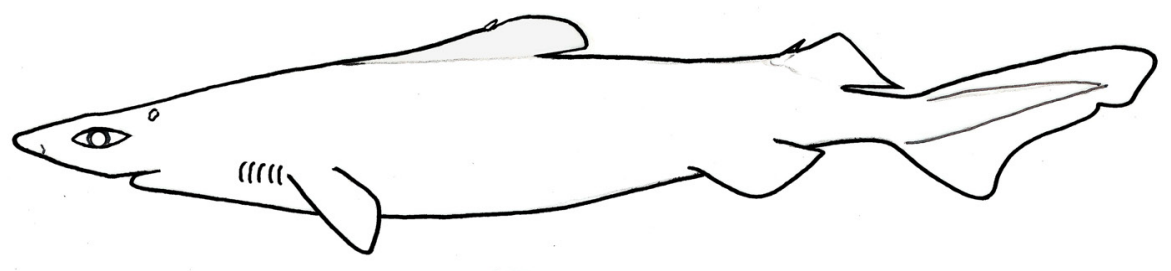

Nomes populares: tubarão-português, tubarão-negro.

Caracteres distintivos: focinho arredondado e relativamente longo, com o comprimento pré-oral igual à largura da boca; primeira nadadeira dorsal estendida anteriormente como uma quilha dérmica, origem sobre a base das nadadeiras peitorais; extremidade da margem livre da segunda nadadeira dorsal próxima à origem superior da nadadeira caudal; espinhos com ápices encobertos por pele ou ligeiramente expostos nas duas nadadeiras dorsais. Coloração castanha escura ou quase preta no dorso e ventre.

Tamanho: atingem CT máximo de aproximadamente um metro.

Distribuição, Hábitos e Biologia: ocorre no Oceano Atlântico Ocidental e Oriental. No Brasil, há registros desde a costa nordestina até o Rio Grande do Sul. Vivem no talude continental dos oceanos, em grandes profundidades (normalmente entre 400-1.200 m). São encontrados sobre o fundo ou próximo ao substrato marinho. Viviparidade lecitotrófica, sem dados conhecidos sobre embriões. Alimentam-se de invertebrados e pequenos peixes ósseos.

Observações: De acordo com Compagno (2003), Centroscymnus cryptacanthus (Regan, 1906) é sinônimo júnior de Centroscymnus owstoni.

\section{Gênero Somniosus}

Esse gênero é caracterizado por não possuir espinhos anteriores às nadadeiras dorsais. Dentes inferiores com cúspides oblíquas. As espécies conhecidas são divididas em dois subgêneros: Somniosus (Somniosus), representado por espécies de grande porte, e Somniosus (Rhinoscymnus), que inclui espécies de proporção corpórea mais modestas. A espécie que ocorre no Brasil, Somniosus antarcticus, pertencente ao primeiro grupo. 


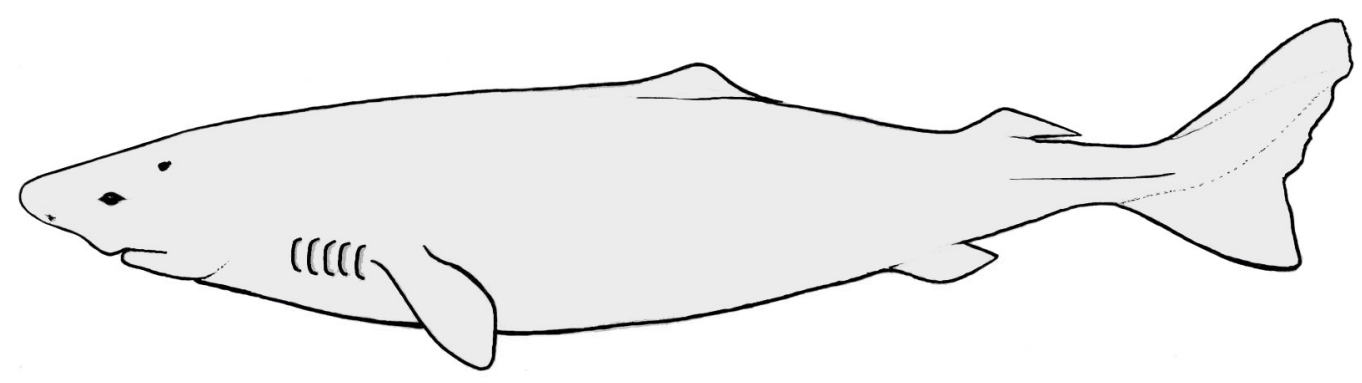

Nome popular: Tubarão sonolento do Atlântico

Caracteres distintivos: Corpo robusto, cabeça larga e arredondada. Origem da primeira nadadeira dorsal mais próxima da extremidade da nadadeira caudal do que da ponta do focinho. Apresenta de 35 a 45 dentes superiores afilados com cúspides retas, e de 53 a 58 dentes inferiores largos, com cúspides baixas e oblíquas. Corpo totalmente cinzento. Coloração da parte ventral do focinho e região em volta da boca enegrecida.

Tamanho: Normalmente atinge cerca de quatro metros de comprimento, podendo chegar aos sete metros de CT.

Distribuição, Hábitos e Biologia: esta espécie ocorre do Espirito Santo atéo Uruguai, próximo aos limites de águas brasileiras. São encontrados em águas profundas, até mais de 1400 metros. (Astarloa et al., 1999; Yano, Stevens \& Compagno, 2004; Menni \& Lucifora, 2007 e Vaz, 2015).

Observações: Dez espécies entre quatro a seis metros de comprimento foram capturadas nas águas fronteiriças entre Uruguai e Brasil (Menni \& Lucifora, 2007).

\section{Gênero Zameus}

É caracterizado por apresentar os espinhos das nadadeiras dorsais nunca encobertos por pele. Dentes inferiores com cúspides eretas. Dentículos dérmicos com microranhuras transversais entre as cristas longitudinais. Só é conhecida espécie Zameus squalulosus.

\section{Zameus squalulosus (Günther, 1877) (Fig. 65)}

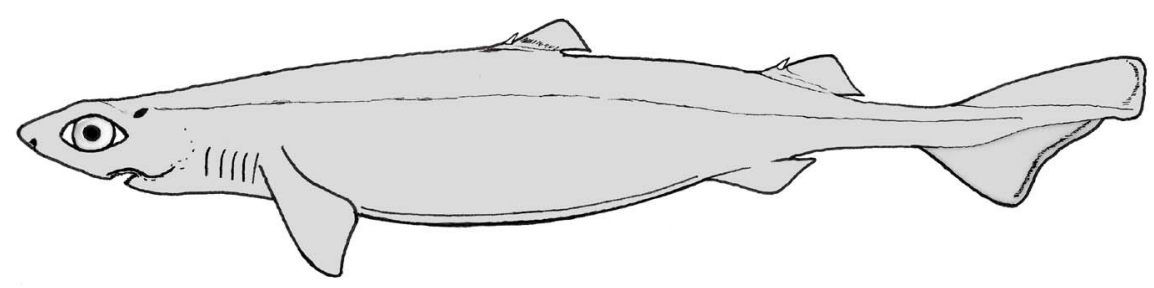

Nome popular: Desconhecido no Brasil 
Caracteres distintivos: Corpo delgado e focinho alongado. Primeira nadadeira dorsal estendida anteriormente como uma quilha dérmica. Sua origem é difícil de observar, porém encontra-se posterior ao ápice da margem interna da nadadeira peitoral. Segunda nadadeira dorsal maior que a primeira nadadeira dorsal, e do mesmo tamanho que a nadadeira pélvica. Espinhos dorsais diminutos, mas nunca cobertos pelo tegumento. Dentículos dérmicos com microranhuras transversais entre as cristas longitudinais. Dentes inferiores com cúspides quase eretas, principalmente na região mediana da arcada. Coloração marrom escura ou quase preta em todo o corpo.

Tamanho: Atingem pouco mais de $80 \mathrm{~cm}$ de CT. Machos são maduros por volta dos $50 \mathrm{~cm}$ e fêmeas, $70 \mathrm{~cm}$ de CT.

Distribuição, Hábitos e Biologia: A espécie, embora rara de ser encontrada, ocorre nos dois lados do Oceano Atlântico, no Oceano Índico oriental e no Indo-Pacífico. Tem vida demersal, por volta dos 500 a $1500 \mathrm{~m}$ de profundidade.

Observações: Existe um registro de captura nas costas do Rio Grande do Sul (macho jovem de $451 \mathrm{~mm}$ de CT) e outro no norte do Rio de Janeiro, sem dados de tamanho e sexo (Nunan \& Senna, 2007).

\section{Família ETMOPTERIDAE}

Caracteriza-se por apresentar as nadadeiras dorsais precedidas por espinhos, dente superior de formato diferente ao inferior: os dentes superiores possuem mais de uma cúspide, enquanto os inferiores são mais largos e oblíquos, com apenas uma cúspide.

Formada por quatro gêneros e cerca de 42 espécies essa família encontrase pobremente representada no Estado do Rio de Janeiro, com apenas um gênero (Etmopterus). Costumam ser chamados de tubarão-vagalume, por possuírem órgãos luminescentes.

\section{Gênero Etmopterus}

Tem como características principais: segunda nadadeira dorsal e seu respectivo espinho visivelmente maior do que a primeira nadadeira dorsal e seu respectivo espinho; sulco pré-caudal superior ausente; ausência de crista lateral no pedúnculo caudal; dentes superiores e inferiores desiguais, os superiores com várias cúspides, e os dentes inferiores com uma única cúspide oblíqua, e um grande entalhe no sentido da comissura da boca (canto da boca). Grupo numeroso e distribuído mundialmente. No Rio de Janeiro, é representado pelas espécies E. bigelowi e E. lucifer. 


\section{Chave de identificação para as espécies do gênero Etmopterus}

1a. Dentículos dérmicos achatados, com coroa côncava (Fig. 66), dando ao animal aspecto e textura lisa; coloração dorsal do corpo pouco contrastante em relação à coloração ventral (Fig. 67, seta).

E. bigelowi

1b. Dentículos dérmicos afilados e cilíndricos, com coroa pontiaguda (Fig. 68), dando ao animal aspecto e textura áspera; coloração dorsal do corpo contrastante em relação à coloração ventral (Fig. 69, seta)

E. lucifer

Etmopterus bigelowi Shirai \& Tachikawa, 1993 (Fig. 70)

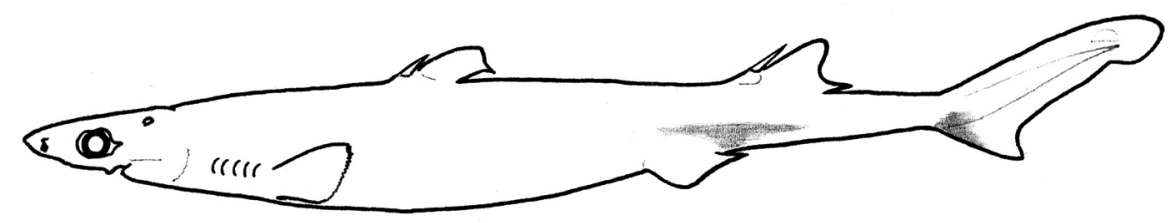

Nome popular: tubarão-vagalume.

Caracteres distintivos: dentículos dérmicos truncados e distribuídos de forma irregular no corpo; a porção posterior da linha lateral forma um sulco aberto nos adultos, localizado próximo ao início do lobo subterminal da nadadeira caudal. Coloração do corpo acinzentada ou castanha dorsalmente, região ventral escura. Lateralmente, na região dos flancos, a coloração é mais clara. Marcas escuras não muito definidas nas seguintes regiões: na lateral do corpo acima das nadadeiras pélvicas, na origem do lobo caudal inferior e na superfície ventral das nadadeiras pélvicas.

Tamanho: CT máximo encontrado para os machos foi de $66,6 \mathrm{~cm}$, e para as fêmeas, 64,6 cm; machos com $42 \mathrm{~cm}$ de CT são imaturos; fêmeas tornam-se maduras a partir de $50 \mathrm{~cm}$ de CT.

Distribuição, Hábitos e Biologia: distribui-se no Pacífico Ocidental (Japão, Austrália), Atlântico Oriental (África Ocidental até Angola; oeste e sul da África do Sul) e Atlântico Ocidental (Golfo do México, Caribe, Suriname, Brasil, Uruguai e Argentina). Encontrada em profundidades de $163 \mathrm{~m}$ a mais de $1.000 \mathrm{~m}$ nas plataformas continentais e taludes insulares. Vivípara lecitotrófica, sem dados sobre embriões. Alimentam-se de moluscos cefalópodes (lulas) e peixes ósseos.

Observações: foi registrada a ocorrência de 14 exemplares de E. bigelowi para o Rio Grande do Sul, dois exemplares para Santa Catarina e dois exemplares para o Espírito Santo, todos juvenis. Existe o registro de um macho jovem de 37,4 cm de comprimento capturado na costa do Estado do Rio de Janeiro. Os registros no Brasil são de exemplares capturados por barcos que operam com espinhéis de fundo. Essas embarcações pescam na borda da plataforma continental, principalmente do Sudeste e Sul, entre 400 a 800 metros de profundidade. O nome poular "tubarão-vagalume" se dá pela presença de órgãos luminescentes sobre o corpo do animal. 


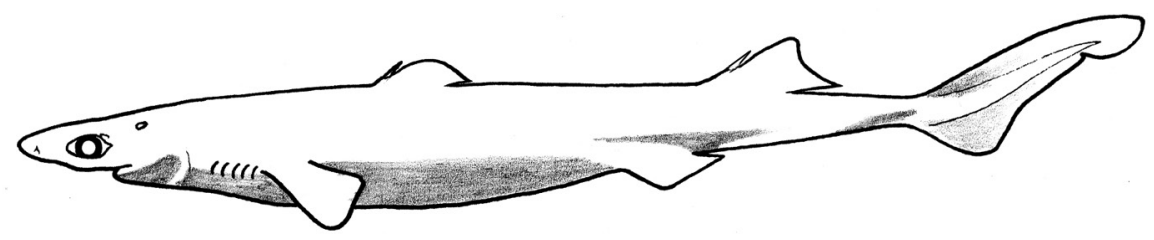

Nomes populares: tubarão-vagalume, tubarão-lanterna.

Caracteres distintivos: dentículos dérmicos distribuídos de forma regular no corpo; dentículos dérmicos afilados (cilíndricos), com coroa ereta e pontiaguda, dando ao animal textura e aspecto ásperos; distância da origem da base das nadadeiras pélvicas até a origem inferior da nadadeira caudal igual à distância da ponta do focinho até a origem da nadadeira peitoral; espaço interdorsal igual ou maior do que a distância da ponta do focinho ao início das nadadeiras peitorais. Coloração castanha na superfície dorsal, e negra abaixo do focinho; ventre com marcas negras alongadas acima, na frente e atrás das nadadeiras pélvicas, bem como na base da nadadeira caudal e em seu eixo.

Tamanho: CT máximo de aproximadamente $42 \mathrm{~cm}$. O holótipo, um macho adulto, mede 28,2 cm de CT. Machos adultos alcançam até $42 \mathrm{~cm}$, fêmeas adultas podem ultrapassar os $34 \mathrm{~cm}$ de CT.

Distribuição, Hábitos e Biologia: ocorre no Pacífico Norte e Sul Ocidental (Japão, China, Indonésia, Filipinas, Austrália, Nova Caledônia e Nova Zelândia), Atlântico Oriental (África do Sul até Moçambique e Tanzânia) e Atlântico Sul-Ocidental (Brasil, Uruguai e Argentina). Na costa brasileira, foi encontrada do Espírito Santo até o Rio Grande do Sul. Vive além das plataformas continentais e insulares em todos os oceanos, em profundidades de 180 a $820 \mathrm{~m}$. Viviparidade lecitrotrófica, sem dados sobre embriões. Alimenta-se de moluscos cefalópodes (lulas) e pequenos peixes ósseos.

\section{ORDEM SQUATINIFORMES}

Grupo com aspecto singular entre os tubarões, possuindo o corpo achatado dorsoventralmente, presença de espiráculo e nadadeira anal ausente (que são características similares às das raias). Apresentam ainda boca terminal e nadadeiras peitorais bem desenvolvidas, com projeções das margens anteriores que cobrem parcialmente as fendas branquiais. A ordem é representada apenas por uma família (Squatinidae). 


\section{Família SQUATINIDAE}

Seus representantes apresentam corpo achatado dorsoventralmente; olhos e espiráculos dorsais; margem anterior das nadadeiras peitorais estendendo-se para frente, ocultando as fendas branquiais; nadadeira anal ausente; margens anteriores da narina com vários lobos achatados; dentes semelhantes nas duas arcadas. A família apresenta apenas o gênero Squatina.

\section{Gênero Squatina}

Caracteriza-se por apresentar cabeça arredondada; nadadeira caudal triangular de contorno truncado ou côncavo; lobo caudal inferior maior que o lobo superior; pedúnculo caudal com uma crista longitudinal lateral bem definida, como se fosse uma delgada dobra de pele. As espécies são muito semelhantes externamente, e sua diferenciação leva em conta os padrões morfológico dos dentículos dérmicos, coloração dorsal, formato dos barbilhões nasais e a fórmula dentária, que embora não seja um caráter estritamente externo, auxilia bastante na identificação. São conhecidas 16 espécies, cinco delas registradas em águas brasileiras. Os primeiros registros de cações-anjo no Oceano Atlântico Ocidental foram efetuados por Schreiner \& Miranda Ribeiro (1903) e Miranda Ribeiro (1907), com base em exemplares capturados no Rio de Janeiro. Squatina dumeril é restrita à região norte e $S$. argentina ocorre apenas na região sul. A espécie recém descrita S.varii, é encontrada da Bahia ao norte do Rio de Janeiro. As duas restantes, $S$. guggenheim e $S$. occulta, distribuem-se no Sudeste e Sul do Brasil. Alguns autores apontam S. occulta como sinônimo de S. guggenheim, e $S$. punctata seria uma espécie válida, mas que foi frequentemente confundida com S. guggenheim. Conforme a revisão do gênero Squatina do Atlântico sul ocidental efetuado por Vaz \& Carvalho (2013), S. punctata é sinônimo júnior de S. guggenheim.

\section{Chave para Identificação das Espécies do Gênero Squatina}

1a.Presença deumafileiradetubérculosdorsaismedianos(Fig. 72)...... Squatinaguggenheim 1b. Ausência de uma fileira de tubérculos dorsais medianos (Fig. 73)..............................2 2a. Ausência de um par de dentículos dérmicos desenvolvidos entre os espiráculos (Fig. 74). Squatina occulta

2b. Presença de um par de dentículos dérmicos desenvolvidos entre os espiráculos (Fig. 75, seta). Squatina varii 


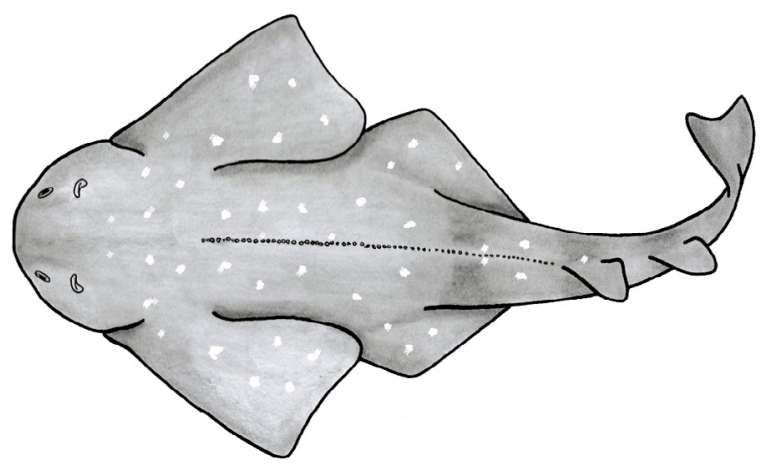

Nome popular: cação-anjo.

Caracteres distintivos: presença de uma fileira de tubérculos dorsais medianos em indivíduos de qualquer tamanho; nos jovens por volta dos $35 \mathrm{~cm}$ podem ocorrer fileiras paralelas de tubérculos, justapostas à fileira central; fêmeas adultas apresentam tubérculos centrais modificados, mais achatados e menos evidentes que aqueles dos jovens e dos machos adultos. Coloração dorsal castanha clara uniforme com manchas escuras transversais no pedúnculo caudal, sendo uma na base da cauda (próxima às nadadeiras pélvicas) e outras na base de cada nadadeira dorsal (esse padrão obscurece nos adultos); ventre claro.

Tamanho: cresce até cerca de $92 \mathrm{~cm}$ de CT, chegando à maturidade sexual em torno de 73 cm; fêmeas são maiores que os machos; nascem com 23 a 25 cm CT.

Distribuição, Hábitos e Biologia: distribui-se no Atlântico Sul Ocidental, desde o Rio de Janeiro até a costa da Argentina. Espécie costeira demersal de águas subtropicais e temperadas, ocorre em profundidades de até $80 \mathrm{~m}$. Dão a luz entre três e oito filhotes, ocorrendo gestação por viviparidade lecitotrófica. Fêmeas com um ovário funcional (dois ovários funcionais em algumas espécies) Alimentam-se de crustáceos (camarões) e pequenos peixes ósseos.

Observação: o Rio de Janeiro corresponde ao limite norte de ocorrência dessa espécie, distribuída até a Patagônia argentina.

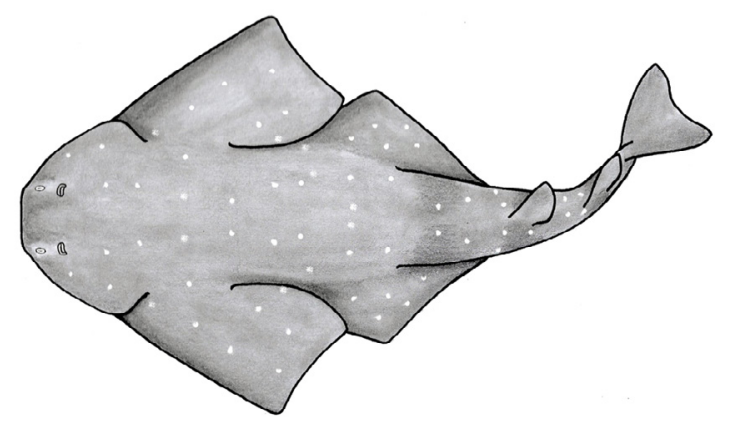


Nome popular: cação-anjo.

Caracteres distintivos: ausência de tubérculos dorsais medianos. Coloração no dorso é castanha uniforme, com numerosas manchas mais claras ou amareladas, de tamanho e disposição irregular, circundadas por diminutos pontos pretos; a superfície ventral do corpo é clara.

Tamanho: Não se conhece exemplares machos adultos. Machos de 97,5 cm de CT ainda não estão maduros; fêmeas de 1,22 $\mathrm{m}$ de CT já são adultas. A maturidade sexual ocorre com cerca de 1,10 m CT; os filhotes nascem medindo entre 28 a $30 \mathrm{~cm} \mathrm{CT}$.

Distribuição, Hábitos e Biologia: ocorre no Atlântico Sul Ocidental. No Brasil, encontra-se desde a costa do Espírito Santo até o Rio Grande do Sul, continuando sua distribuição até o sul do Uruguai, próximo ao estuário do Rio de La Plata. Espécie demersal, pode ocorrer até cerca de $300 \mathrm{~m}$ de profundidade. Nascem de quatro a dez filhotes por parto. Fêmeas apenas com o ovário esquerdo funcional. Alimentam-se preferencialmente de pequenos peixes ósseos.

Squatina varii Vaz \& Carvalho, 2013 (Fig. 78)

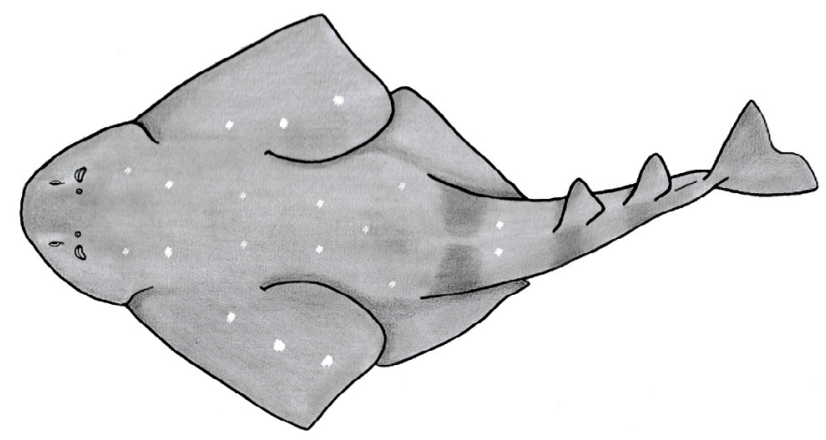

Nome popular: cação-anjo.

Caracteres distintivos: ausência de tubérculos dorsais medianos. A presença de um par de dentículos dérmicos desenvolvidos entre os espiráculos são característicos dessa espécie. Coloração no dorso castanha uniforme, com pouquíssimas manchas brancas ou amareladas, de tamanho e disposição quase simétrica no dorso (essas manchas não são circundadas por diminutos pontos pretos, como ocorre em Squatina oculta); ventre claro.

Tamanho: O maior exemplar já registrado foi uma fêmea de 1,23 m de CT. O maior macho encontrado mediu aproximendamente 1,25 $\mathrm{m}$ de CT.

Distribuição, Hábitos e Biologia: ocorre no Atlântico Sul Ocidental, apenas no Brasil, na plataforma continental desde a costa de Sergipe até o norte do Rio de Janeiro, entre 195 a $666 \mathrm{~m}$ de profundidade. Fêmeas possuem os dois ovários funcionais. A maturidade sexual para ambos os sexos ocorre entre $95 \mathrm{~cm}$ a 1,08 $\mathrm{m}$ de CT. 


\section{ORDEM LAMNIFORMES}

Corpo fusiforme, focinho pontiagudo (exceto em Megachasma), presença de nadadeira anal. Olhos situados anteriormente em relação aos cantos da boca (Fig. 9). Membrana nictitante ausente. Na maioria dos casos a primeira nadadeira dorsal é bem maior, e diferente quanto à forma da segunda nadadeira dorsal (Fig. 106). Os tubarões dessa ordem são, em sua maioria, de grande porte, podendo alcançar cerca de $12 \mathrm{~m}$ de CT (ex. Cetorhinus maximus), com a exceção do Pseudocarcharias kamoharai que atinge pouco mais de um metro. Apresentam hábitos preferencialmente pelágicos, em regiões costeiras ou oceânicas, mas alguns exemplares podem ser encontrados em profundidades de cerca de $1.000 \mathrm{~m}$. Tubarões dessa ordem apresentam uma importante modificação anatômica-fisiológica em seu sistema circulatório (rete mirabilia) que lhes permite manter a temperatura dos músculos e vísceras acima da temperatura da água. Essa diferença pode atingir cerca de 8ㅇ $\mathrm{C}$ em alguns tubarões da família Lamnidae. Das oito famílias existentes no mundo, cinco estão representadas em águas fluminenses.

\section{Chave para Identificação das Famílias da Ordem Lamniformes}

1a. Focinho muito alongado e achatado; sem sulcos pré-caudais; nadadeira caudal sem lobo inferior bem definido, nadadeira anal arredondada............Mitsukurinidae 1b. Focinho curto ou moderadamente alongado; com sulcos pré-caudais (superior e/ ou inferior); nadadeira caudal com lobo inferior definido, nadadeira anal angular ...2 2a. Bocaterminal (Fig. 79) Megachasmidae

2b. Boca subterminal (Fig. 8o ).

3a. Lobo superior da nadadeira caudal muito desenvolvido, com o comprimento aproximadamente igual ao do resto do corpo (Fig. 81)

Alopiidae

3b. Lobo superior da nadadeira caudal pouco desenvolvido, com o comprimento menor que o do resto do corpo (Fig. 82) .............................................................................

4a. Sem cristas dérmicas laterais no pedúnculo caudal (Fig. 83, seta)...Carchariidae

4b. Com cristas dérmicas laterais no pedúnculo caudal (Fig. 84, seta).........................5

5a. Lobo inferior da nadadeira caudal quase tão desenvolvido quanto o superior, com aspecto de meia-lua (Fig. 85)

Lamnidae

5b. Lobo inferior da nadadeira caudal visivelmente menos desenvolvido que o superior, sem aspecto de meia-lua (Fig. 86).

6a. Fendas branquiais muito grandes, se estendendo até a superfície dorsal e ventral da cabeça (Fig. 87); dentes numerosos, com mais de 150 fileiras em cada arcada (cerca de 300 totais)

Cetorhinidae

6b. Fendas branquiais pequenas, não se estendendo até a superfície dorsal e ventral da cabeça (Fig. 88); dentes pouco numerosos, com menos de 150 fileiras em cada arcada (45 a 52 totais) Pseudocarcharhiidae 


\section{Família MITSUKURINIDAE}

Focinho muito alongado e achatado. Sulcos pré-caudais ausentes; nadadadeira caudal sem lobo inferior bem definido, nadadeira anal arredondada.

\section{Gênero Mitsukurina}

Características semelhantes às da família.

Mitsukurina owstoni Jordan, 1898 (Fig. 89)

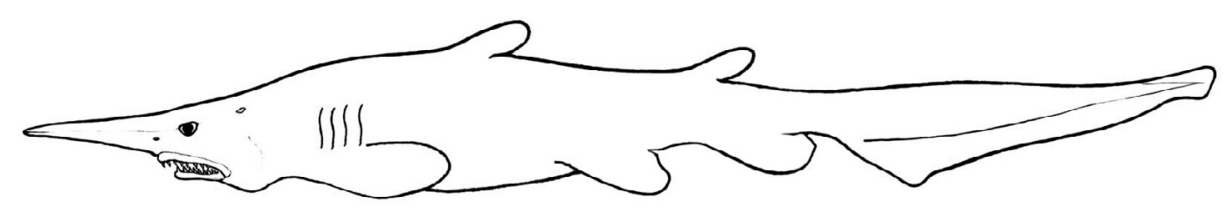

Nome popular: Tubarão duende

Caracteres distintivos: Focinho muito alongado e achatado. Sulcos pré-caudais ausentes; nadadadeira caudal sem lobo inferior bem definido, nadadeira anal arredondada. Olhos muito pequenos. Boca larga, bastante protrátil. Dentes longos e afilados. Nadadeiras peitorais curtas e largas. Nadadeiras dorsais arredondadas, baixas e pequenas, quase do mesmo tamanho, e menores do que a nadadeira anal. Apresentam a coloração coloração rosa esbranquiçada quando capturados (em vida), passando ao castanho claro quando são fixados.

Tamanho: $\mathrm{O}$ tamanho máximo encontrado foi de 3,84 $\mathrm{m}$ de CT. O menor exemplar registrado mediu 1,07 $\mathrm{m}$ de CT. Entre 2,64 e 3,84 $\mathrm{m}$ de CT os machos atingem a maturidade, e as fêmeas entre 3,35 e 3,73 m CT.

Distribuição, Hábitos e Biologia: Encontrada nas Guianas, Guiana Francesa e Suriname, França, Portugal, Senegal, Golfo da Guiné, África do Sul, Oceano Índico, Japão, Australia, Nova Zelândia, Sul da California. Espécie pouco conhecida, com hábitos de fundo, na região mais afastada da plataforma continental. Registrados em profundidade entre 270 e $1300 \mathrm{~m}$.

No Brasil os primeiros registros foram no Norte. Entretanto um macho adulto de 3,15 m de CT foi capturado na costa norte do Estado do Rio de Janeiro, à profundidade de 1000 metros (Hollanda \& Asano-Filho, 2008 e observação de um dos autores: OBFG). 


\section{Família MEGACHASMIDAE}

Boca terminal; dentes diminutos e numerosos: de 55 a 115 na arcada superior e de 75 a 121 na arcada inferior. Focinho extremamente curto, achatado e arredondado. Aberturas branquiais moderadamente desenvolvidas, as duas últimas fendas são posicionadas próximas à base da nadadeira peitoral. Origem da segunda nadadeira dorsal posterior à origem da nadadeira anal.

\section{Gênero Megachasma}

Características semelhantes às da família.

Megachasma pelagios Taylor, Compagno \& Struhsaker, 1983 (Fig. 90)

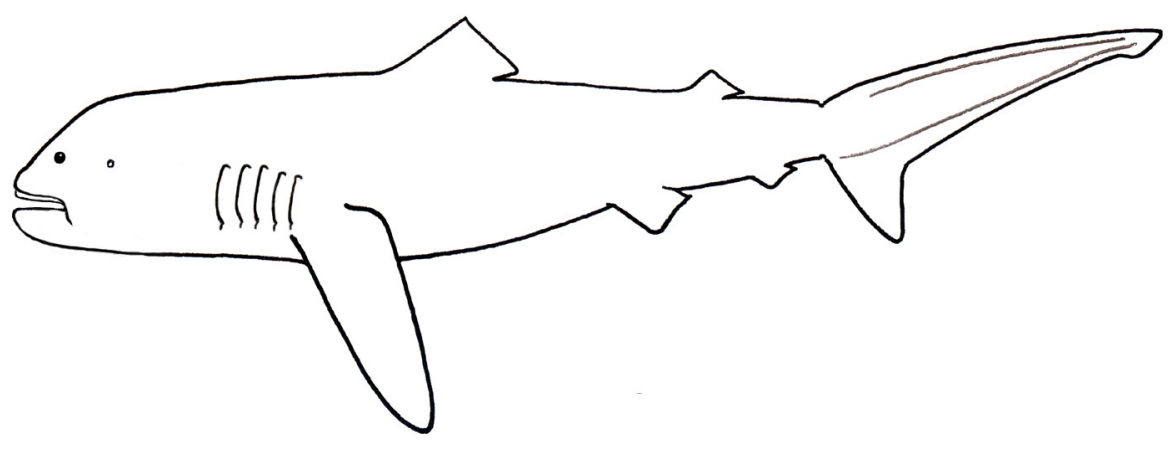

Nomes populares: megaboca, tubarão-de-boca-grande.

Caracteres distintivos: boca terminal; focinho bastante curto e amplamente arredondado. Espiráculo presente; presença de estrias na região da garganta.

Tamanho: atinge comprimento máximo entre 6,1 e 7,6 m de CT, de acordo com o registro de um exemplar capturado na Califórnia em 2003. Com quatro metros de CT já são adultos. Os menores exemplares conhecidos (e considerados juvenis) medem entre 1,80 e 1,90 metros de CT.

Distribuição, Hábitos e Biologia: Megachasma pelagios é elasmobrânquio filtrador, junto com os representantes das famílias Mobulidae, Cetorhinidae e Rhincodontidae. Essa espécie é cosmopolita, com registros principalmente no oceano Pacífico; ocorrendo também no oceano Atlântico e no oceano Índico. A captura de alimentos é semelhante ao de muitas baleias. Com deslocamentos verticais diários do peixe na coluna d'água, o zooplâncton é capturado através de engolfamento. Ao nadar, o tubarão engole grande quantidade de água. A região bucofaringeana se expande devido à sua elasticidade, incrementada por sulcos (dobras) presentes em suas paredes. Ao fechar a boca, a água sai pelas fendas branquiais e o alimento retido é engolido. Nos poucos conteúdos estomacais examinados, foram encontrados crustáceos eufausiídeos, copépodos e águas-vivas. Provavelmente esses tubarões são vivíparos aplacentários, embora nenhuma fêmea grávida tenha sido capturada. 
Em alguns exemplares foram observadas feridas, atribuídas a ataques de cações do gênero Isistius.

Observações: no dia 9 de julho de 2009 foi encontrado um exemplar de 5,39 m encalhado na Praia Grande, em Arraial do Cabo, no Rio de Janeiro. Trata-se do $44^{\circ}$ registro de ocorrência no mundo, do terceiro no Oceano Atlântico, do segundo no Brasil e o primeiro no Rio de Janeiro. No ano de 1995, foram capturados dois exemplares no Oceano Atlântico, um na costa do Estado de São Paulo (18 de setembro) e outro em Dakar (4 de maio), no Senegal. Ambos eram machos imaturos, medindo respectivamente 1,9 m e 1,8 m de CT. Pesquisadores do Projeto de Monitoramento de Aves, Quelônios e Mamíferos Marinhos da Bacia de Campos, Instituto Oceanites, e pela Escola Nacional de Saúde Pública da Fiocruz, que tiveram acesso ao exemplar, acreditam que o peixe tenha morrido de causas naturais, uma vez que nenhuma marca de rede ou colisão foi encontrado. Fizeram necropsia e verificaram que o estômago estava vazio, o que poderia indicar, segundo os pesquisadores, que o tubarão não se alimentava há dias.

O último registro de ocorrência dessa espécie no Brasil foi em setembro de 2018 na Praia do Sal, Parnaíba, a 318 km de Teresina, Estado do Piauí. O animal apareceu boiando, sem vida, e sua carne foi dividida entre os pescadores (observação de um dos autores: OBFG).

\section{Família ALOPIIDAE}

Os tubarões dessa família possuem a nadadeira caudal bem desenvolvida, com o lobo superior perfazendo cerca da metade do comprimento total do corpo. Há um gênero e três espécies no mundo. Duas dessas espécies, Alopias superciliosus e Alopias vulpinus, são encontradas em águas fluminenses.

\section{Gênero Alopias}

As características do gênero são semelhantes às da família: tubarões de grande porte, com o comprimento total de até aproximadamente $5,5 \mathrm{~m}$ de CT. São encontrados em todos os oceanos, da costa até a região oceânica. Apresentam um comportamento de caça exclusivo, nadando em círculos cada vez menores ao redor de suas presas e por fim utilizando sua nadadeira caudal como um chicote para atordoá-las e limitar suas rotas de fuga. 


\section{Chave para Identificação das Espécies do Gênero Alopias}

1a. Região dorsal da cabeça com uma reentrância em forma de "V" quando vista de cima; olhos desenvolvidos, com órbitas estendidas até a superfície dorsal da cabeça; margem livre da primeira nadadeira dorsal sobre a origem das nadadeiras pélvicas (Fig. 91); 22 séries de dentes superiores e 20 séries de dentes inferiores.

A. superciliosus 1b. Região dorsal da cabeça sem reentrância; olhos menores, com órbitas não estendidas até a superfície dorsal da cabeça; margem livre da primeira nadadeira dorsal anterior à origem das nadadeiras pélvicas (Fig. 92); 40 séries de dentes superiores e 42 séries de dentes inferiores.

A. vulpinus

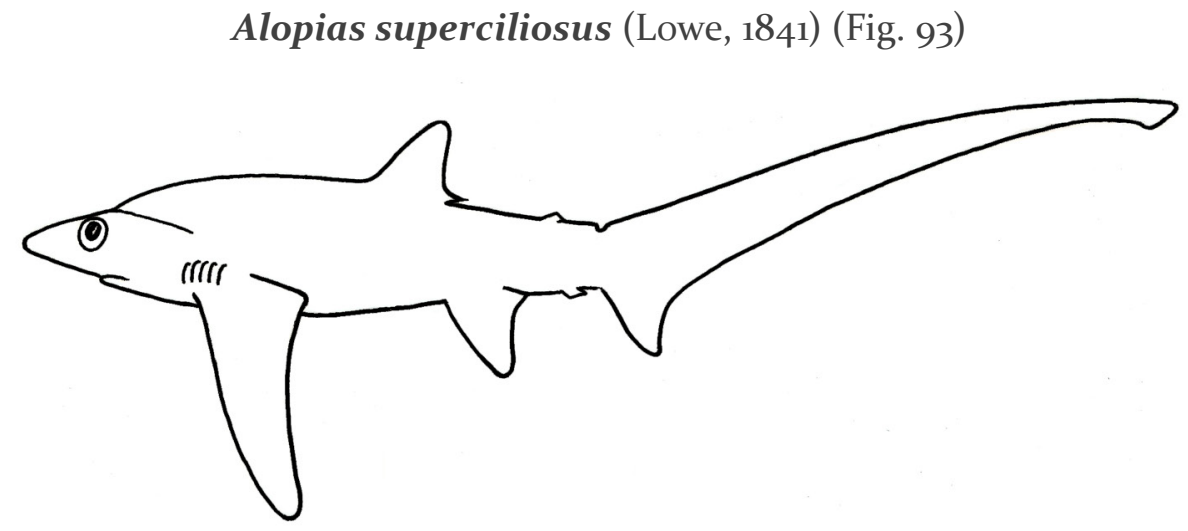

Nomes populares: tubarão-raposa, raposa, raposa-olhuda.

Caracteres distintivos: região dorsal da cabeça com um profundo sulco em forma de "V"; olhos bem desenvolvidos, com órbitas estendidas até a superfície dorsal da cabeça; origem da primeira nadadeira dorsal situada mais próxima da origem da nadadeira da pélvica do que da inserção das nadadeiras peitorais; margem livre da primeira nadadeira dorsal sobre a origem das nadadeiras pélvicas; arcada superior com cerca de 22 séries de dentes e arcada inferior com cerca de 20 séries. Coloração castanha escura nas laterais e no dorso; ventre um pouco mais claro.

Tamanho: atinge cerca de 4,5 $\mathrm{m}$ de CT; ao nascer medem aproximadamente um metro de comprimento.

Distribuição, Hábitos e Biologia: encontrada em regiões oceânicas (até $500 \mathrm{~m}$ de profundidade) e costeiras de todos os oceanos, em águas rasas na plataforma continental. Espécie registrada ao longo de toda a costa brasileira. Desenvolvimento embrionário por viviparidade ovofágica, parindo de dois a quatro filhotes por vez, normalmente dois por útero. Alimentação constituída de moluscos (lulas) e peixes ósseos pelágicos e bentônicos.

Observações: essa espécie é relativamente mais frequente nas regiões sudeste e sul do Brasil que A. vulpinus. Uma cauda de Alopias (espécie não identificada) foi encontrada na década de 1980, na colônia de pesca de Barra de Guaratiba- RJ. Sua coleta se deu ao largo da Restinga de Marambaia (observação de um dos autores: ULG). 


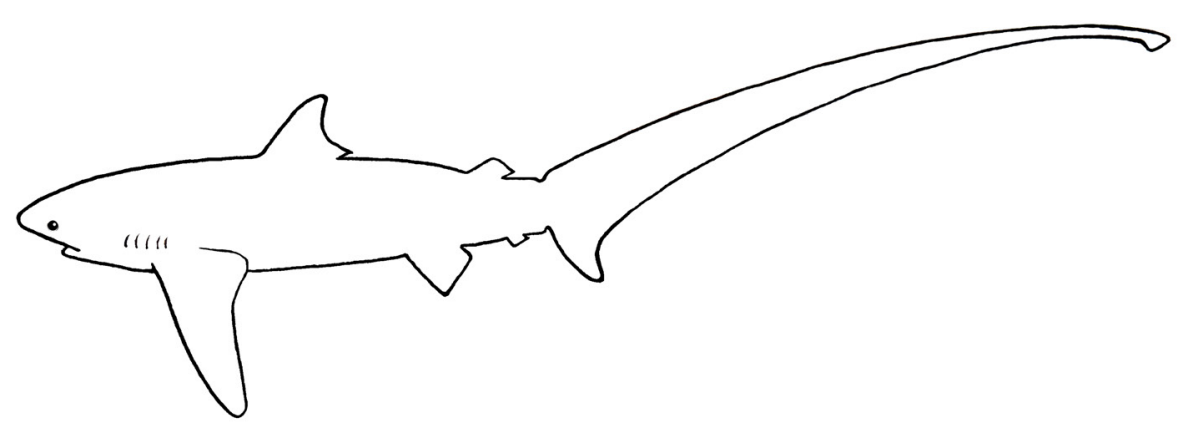

Nomes populares: tubarão-raposa, raposa, rabudo.

Caracteres distintivos: região dorsal da cabeça sem sulco em forma de "V"; olhos pouco desenvolvidos, com órbitas não estendidas até a superfície dorsal da cabeça; origem da primeira nadadeira dorsal equidistante entre a inserção das nadadeiras peitorais e a origem das nadadeiras pélvicas; margem livre da primeira nadadeira dorsal anterior à origem das nadadeiras pélvicas; arcada superior com cerca de 40 séries de dentes, e arcada inferior com cerca de 42 séries. Coloração cinza azulada no dorso, com reflexos metálicos nos flancos; jovens podem exibir extremidade das nadadeiras mais clara; ventre com uma tonalidade mais clara, que avança sobre a base das nadadeiras peitorais.

Tamanho: máximo comprimento por volta de 5,5 $\mathrm{m}$ de CT, e ao nascer variando de 1 a $1,5 \mathrm{~m}$ de CT.

Distribuição, Hábitos e Biologia: distribuição na região oceânica (até $350 \mathrm{~m}$ de profundidade) e costeira em todos os oceanos, vivendo na região epipelágica da plataforma continental, e área oceânica. Aspectos reprodutivos semelhantes aos de A. superciliosus. Estratégia de desenvolvimento embrionário se faz por viviparidade ovofágica, parindo de dois a quatro filhotes por vez. Alimentação constituída de moluscos (cefalópodes), crustáceos e peixes ósseos pelágicos.

Observações: são nadadores ativos e velozes, podendo dar saltos para fora da água. Registros conhecidos para o Rio de Janeiro são raros. Em Janeiro de 1983, um indivíduo com dois metros de comprimento foi capturado a quatro milhas náuticas da costa do Estado. Outro exemplar foi visto sendo desembarcado na colônia de pesca Z-13 em Copacabana. Pesava $27 \mathrm{~kg}$ e tinha cerca de dois metros de comprimento. Teve a cabeça e nadadeira caudal encaminhada à Universidade Federal do Estado do Rio de Janeiro (UNIRIO).

\section{Família CARCHARIIDAE}

Caracteriza-se por não possuir cristas dérmicas laterais no pedúnculo caudal; dentes superiores e inferiores (próximo à sínfise) iguais, apresentando margem lisa, sem serrilhas e com uma cúspide principal estreita e uma cúspide secundária de 
cada lado. Uma característica interessante desse grupo é o canibalismo intrauterino (adelfofagia), onde os embriões mais desenvolvidos alimentam-se dos embriões mais recentes, de maneira que nascem apenas dois filhotes por vez, um por útero.

Até então Carcharias taurus estava incluída na família Odontaspididae junto com Odontaspis noronhai e Odontaspis ferox. Stone \& Shimada (2019) baseados na anatomia esquelética, verificaram que a família Odontaspididae não e monofolética. Os autores ressuscitaram a família Carchariidae para o gênero Carcharias separando da família Odontaspididae para o gênero Odontaspis. Os gêneros Carcharias e Odontaspis ocorrem no Brasil sendo o primeiro ocorrente no Estado do Rio de Janeiro. Não é descartada a ocorrência de Odontaspis em águas profundas ao largo da região.

\section{Gênero Carcharias}

Caracteriza-se pela primeira nadadeira dorsal com tamanho aproximadamente igual ao da segunda dorsal; sua origem equidistante entre as nadadeiras peitorais e as nadadeiras pélvicas; segunda nadadeira dorsal com origem posterior à inserção da nadadeira pélvica; focinho achatado; três fileiras de dentes anteriores em cada lado da arcada superior. Somente uma espécie ocorre no Brasil, Carcharias taurus.

Carcharias taurus Rafinesque, 1810 (Fig. 95)

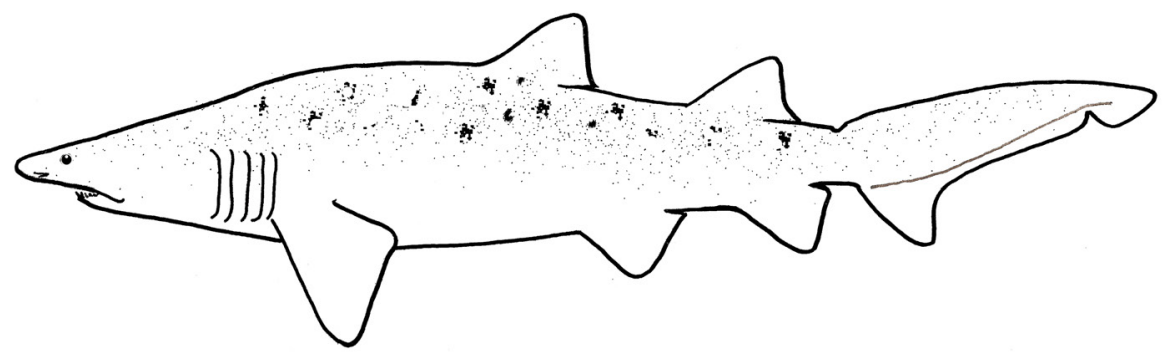

Nomes populares: mangona, cação-mangona.

Caracteres distintivos: nadadeira peitoral originando-se atrás da quinta fenda branquial; primeira nadadeira dorsal com origem posterior à inserção das nadadeiras peitorais; segunda nadadeira dorsal com origem posterior à inserção das nadadeiras pélvicas; segunda nadadeira dorsal com tamanho aproximadamente igual ao da nadadeira anal. Coloração dorsal castanha clara; superfície dorsal das nadadeiras peitorais e caudal com vários pontos ovais escuros; ventre e parte inferior das nadadeiras cinza-esbranquiçado.

Tamanho: CT máximo por volta de 4,3 m; machos se tornam sexualmente maduros entre 1,9 e 1,95 m e fêmeas, a partir de 2,2 $\mathrm{m}$ de CT; nascem com cerca de $95 \mathrm{~cm}$ a 1,05 $m$ de CT. Duas fêmeas jovens encontradas em maio de 1982, em Barra de Guaratiba, RJ, mediram 1,56 m e 2,54 m de CT, respectivamente. No primeiro semestre do ano não são raras as notícias de aparições dessa espécie no Rio de Janeiro e São Paulo. 
Distribuição, Hábitos e Biologia: distribuição costeira em águas tropicais e temperadas. No Oceano Atlântico Ocidental, é possível que ocorra ao sul do Espírito Santo até a Argentina. Pode ser encontrada desde a superfície, chegando até a profundidade de quase $200 \mathrm{~m}$ sobre o fundo marinho. Nada lentamente sozinho ou em pequenos cardumes. Quanto ao desenvolvimento embrionário, a espécie é vivípara ovofágica, mas pode também ingerir embriões menores (adelfofagia). Produz dois filhotes por vez, com período de gestação de nove a 12 meses. O caçãomangona é mais ativo durante a noite, alimentando-se vorazmente de uma grande variedade de moluscos cefalópodes (lulas), crustáceos (caranguejos), peixes ósseos, outros tubarões e raias. Por vezes é observado caçando em cardumes.

Observações: sabe-se que essa espécie faz migrações sazonais para reprodução no Oceano Atlântico na costa brasileira. Provavelmente as fêmeas são fecundadas no sul do país (ou Uruguai e Argentina), efetuando uma migração para o Sudeste do Brasil. No Rio de Janeiro, nos meses de maio e junho já foi comum sua presença, quando fêmeas com os fetos quase a termo são lamentavelmente capturadas. Nessa época, nadam mais próximo à costa, onde o alimento é mais abundante. Em 2003, uma fêmea foi facilmente capturada na zona de arrebentação da Praia da Joatinga (Rio de Janeiro) e cruelmente morta a por golpes deferidos por populares, fato que proporcionou grande repercussão da mídia. Espécie considerada vulnerável para o município do Rio de Janeiro, de acordo com a listagem de fauna ameaçada em extinção (Buckup et al., 200o).

\section{Família PSEUDOCARCHARIIDAE}

Caracteriza-se por possuir fendas branquiais pequenas, não estendidas até a superfície dorsal e ventral da cabeça (Fig. 96); quilha dérmica lateral no pedúnculo caudal presente, e lobo inferior da nadadeira caudal pouco desenvolvido, sem aspecto de meia-lua; dentes pouco numerosos, com menos de 150 fileiras em cada arcada (45 a 52 totais). Apenas uma espécie conhecida: Pseudocarcharias kamoharai.

\section{Gênero Pseudocarcharias}

Possui sulcos pré-caudais inferior e superior presentes; segunda nadadeira dorsal menor do que a primeira nadadeira dorsal e maior que a nadadeira anal. 


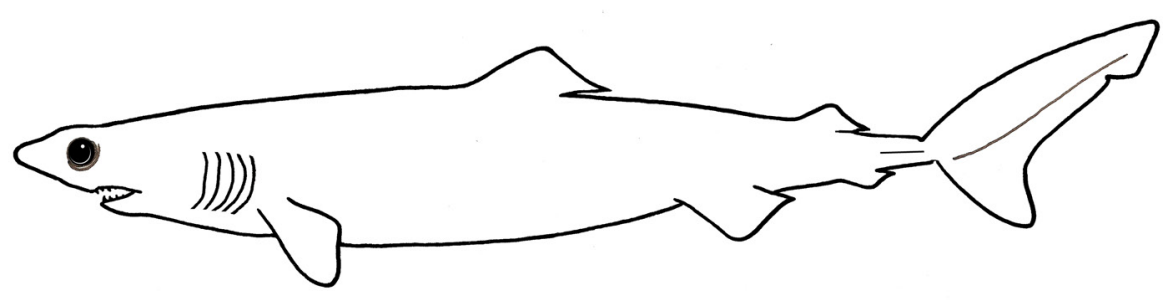

Nomes populares: tubarão-oceânico, tubarão-crocodilo.

Caracteres distintivos: olhos muito desenvolvidos, com diâmetro horizontal cabendo aproximadamente 1,5 vezes na distância internasal; fendas branquiais anteriores à nadadeira peitoral; primeira nadadeira dorsal maior que a segunda, com o comprimento de sua base mais ou menos o dobro da base da segunda nadadeira dorsal. Origem da primeira nadadeira dorsal posterior à margem interna das nadadeiras peitorais; nadadeira caudal assimétrica, com lobo inferior compreendendo menos da metade do lobo superior, e com lobo terminal bem evidente. Coloração cinza ou castanha acinzentada no dorso; borda posterior das nadadeiras dorsais mais claras; ventre mais claro; pode apresentar pequenas manchas negras nos flancos e ventre.

Tamanho: CT de cerca de um metro, sendo o menor representante de Lamniformes; machos amadurecem com aproximadamente $74 \mathrm{~cm}$, e fêmeas a partir de $89 \mathrm{~cm}$ de CT; nascem com $41 \mathrm{~cm}$ de CT.

Distribuição, Hábitos e Biologia: presente em todos os oceanos, essa espécie é encontrada do Nordeste ao Sul do Brasil. Habita preferencialmente a região oceânica epipelágica e mesopelágica. Seus olhos desenvolvidos sugerem atividade noturna e em águas profundas e, possivelmente, a realização de migração vertical durante a noite. Desenvolvimento embrionário ovovivíparo ovofágico, sem canibalismo intrauterino comprovado, parindo quatro filhotes por vez, dois por útero. Pouco é conhecido sobre sua alimentação, mas é aparentemente constituída de crustáceos (principalmente camarões), cefalópodes e pequenos peixes ósseos pelágicos.

Observações: até o momento, não foi encontrada em águas fluminenses. Contudo, sua ocorrência é relativamente frequente na região Norte e mais rara nas regiões Sudeste e Sul do Brasil. Assim, é muito provável que Pseudocarcharias kamoharai ocorra também em águas pelágicas do Estado do Rio de Janeiro. O aumento do esforço de pesca na região pelágica do litoral fluminense, muito provavelmente levará ao registro dessa espécie.

\section{Família CETORHINIDAE}

Seus representantes possuem fendas branquiais muito grandes, estendidas até a superfície dorsal e ventral da cabeça; dentes numerosos, com mais de 150 fileiras em cada arcada (cerca de 300 fileiras totais). Apenas uma espécie conhecida, Cetorhinus maximus. 


\section{Gênero Cetorhinus}

Diagnose da família é suficiente para reconhecimento do gênero.

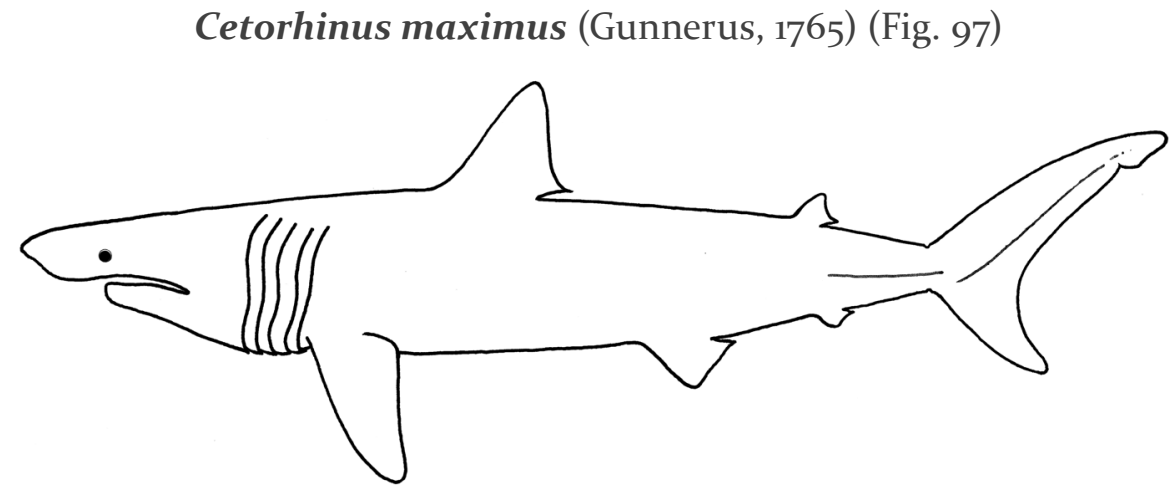

Nomes populares: tubarão-peregrino, tubarão-gigante.

Caracteres distintivos: cabeça volumosa e boca muito grande, com focinho quase cônico nos adultos; apresentam região do focinho (pré-orbital) destacada, semelhante a uma tromba (probóscide); dentes unicuspidados, diminutos e numerosos (mais de 150 em cada série de cada lado da arcada) e, semelhantes em ambas as arcadas; fendas branquiais anteriores à origem das nadadeiras peitorais; origem da primeira nadadeira dorsal posterior à nadadeira peitoral, com comprimento de sua base cerca de três vezes o comprimento da base da segunda nadadeira dorsal; origem da segunda nadadeira dorsal anterior à nadadeira anal, com tamanhos equivalentes; pedúnculo caudal com fortes cristas dérmicas laterais, e com sulco pré-caudal superior presente; nadadeira caudal assimétrica, seu lobo inferior com cerca de $2 / 3$ do comprimento do lobo superior. Coloração castanha escura a enegrecida em ambas as superfícies e nas nadadeiras; algumas vezes o ventre é mais claro com manchas esbranquiçadas sob a cabeça e o abdômen.

Tamanho: Os indivíduos do Hemisfério Norte chegam aos $12 \mathrm{~m}$ de CT, mas normalmente atingem 9,8 m. Estima-se que machos amadureçam entre quatro e sete metros, e fêmeas, entre oito e nove metros. Tamanho ao nascer estimado entre 1,5 e 1,7 m de CT. Um exemplar de 5,07 m de CT capturado na Praia do Canto em Barra de Guaratiba era um macho com os clásperes no início do desenvolvimento. É a segunda maior espécie de tubarão.

Distribuição, Hábitos e Biologia: distribuição costeira em todos os oceanos, preferencialmente em águas temperadas, mas também encontrada em águas tropicais frias. Distribui-se pelo Sudeste e Sul do Brasil. Presumivelmente vivíparo, como outros Lamniformes. Alimenta-se por filtração do plâncton que fica retido em seus rastelos branquiais, enquanto o tubarão nada com a boca amplamente aberta. Não faz sucção da água como os tubarões-baleia (Rhincodon typus).

Observações: até o presente, foram registradas apenas três ocorrências do tubarãoperegrino no Estado do Rio de Janeiro. O primeiro e o segundo registros (todos 
machos juvenis) se deram na região de Barra de Guaratiba, em maio de 1982 e março de 1983 respectivamente. O terceiro registro se deu na região de Itaipuaçu, município de Niterói, em novembro de 2001. Neste último, um exemplar macho imaturo de 4,6 $\mathrm{m}$ foi capturado entre 9:30 e 11:30h numa rede de espera de meia água, a $50 \mathrm{~m}$ da praia. Peças anatômicas desses exemplares estão na coleção da UERJ. Considerada criticamente em perigo para o município do Rio de Janeiro, de acordo com a listagem de fauna ameaçada em extinção (Buckup et al. 200o).

\section{Família LAMNIDAE}

Apresenta cristas dérmicas laterais no pedúnculo caudal; lobo inferior da nadadeira caudal quase tão desenvolvido quanto o lobo caudal superior, com aspecto de meia-lua; forma do corpo extremamente hidrodinâmica; focinho cônico; sulcos pré-caudais superior e inferior presentes; dentes com ou sem margens serrilhadas. Os tubarões dessa família são considerados perigosos, em função de diversos registros de ataques a humanos. Há três gêneros: Carcharodon, Lamna e Isurus, todos ocorrentes no Estado do Rio de Janeiro.

\section{Chave para Identificação dos Gêneros da Família Lamnidae}

1a. Dentes largos, triangulares e serrilhados (Fig. 98) Carcharodon

1b. Dentes estreitos e com margens lisas (Fig. 99).....

2a. Dentes com cúspides secundárias (Fig. 100, setas); origem da primeira nadadeira dorsal sobre a inserção ou sobre as margens internas das nadadeiras peitorais (Fig. 101) origem da segunda nadadeira dorsal sobre a origem da nadadeira anal (Fig. 102); crista dérmica secundária presente no lobo inferior da nadadeira caudal (Fig. 102, seta)

Lamna

2b. Dentes sem cúspides secundárias (Fig. 103); origem da primeira nadadeira dorsal posterior às margens internas das nadadeiras peitorais (Fig. 104); origem da segunda nadadeira dorsal anterior à origem da nadadeira anal (Fig. 105); crista dérmica secundária ausente no lobo inferior da nadadeira caudal (Fig. 105, seta)....

Isurus

\section{Gênero Carcharodon}

Caracteriza-se por seus dentes largos, triangulares e com margens serrilhadas; em juvenis com menos de dois metros de comprimento, os dentes podem apresentar discretas cúspides secundárias. Apenas uma espécie conhecida, Carcharodon carcharias. 


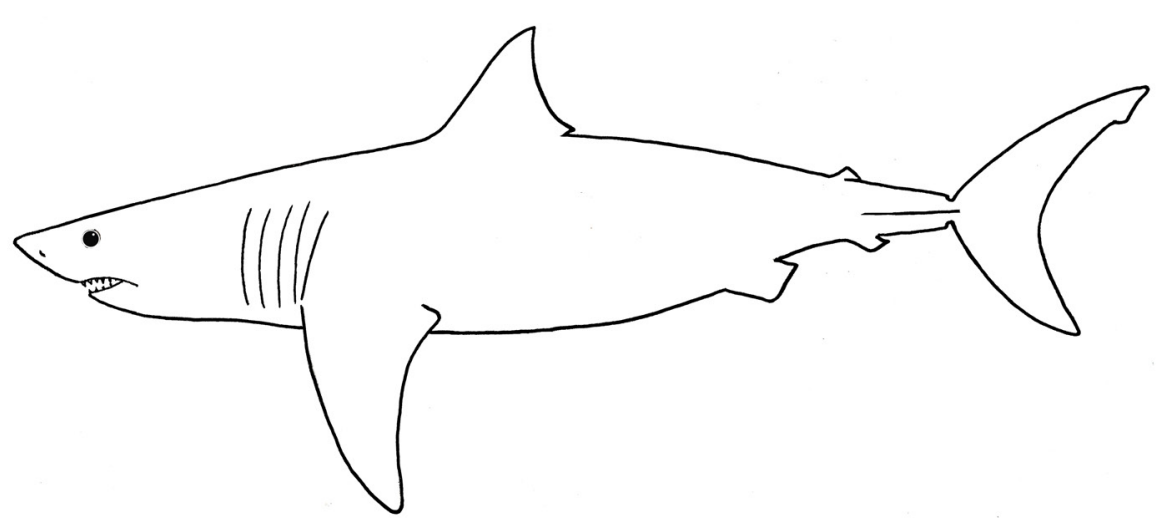

Nomes populares: tubarão-branco, anequim, tubarão-boto, espelho.

Caracteres distintivos: dentes triangulares, unicuspidados e com margens serrilhadas (indivíduos com menos de dois metros de CT apresentam discretas cúspides secundárias); dentes superiores mais largos em relação aos inferiores; origem da primeira nadadeira dorsal sobre ou pouco posterior às margens internas das nadadeiras peitorais; nadadeira anal posterior à origem da segunda nadadeira dorsal; nadadeira caudal quase simétrica, comprimento do lobo inferior mais de $2 / 3$ do comprimento do lobo superior. Coloração dorsal variando entre cinza e bronzeada, eventualmente com tons metálicos; axila das nadadeiras peitorais pode apresentar mancha negra; face ventral das nadadeiras peitorais mais escuras; ventre claro, limite entre as colorações dorsal e ventral é contrastante e bem definido.

Tamanho: comprimento máximo supostamente de oito $\mathrm{m}$ de $\mathrm{CT}$, podendo alcançar mais do que isso (o maior indivíduo registrado mediu pouco mais de seis $\mathrm{m}$ de CT); machos tornam-se maduros sexualmente com cerca de três a quatro metros, e fêmeas entre quatro e 4,5 m; tamanho ao nascer entre 1,2 e 1,5 m CT.

Distribuição, Hábitos e Biologia: cosmopolita, distribuída na região costeira em todos os oceanos, dos trópicos a latitudes maiores. Frequenta a zona pelágica da plataforma continental podendo penetrar em baías e chegar bem próximo das praias. Distribuição vertical de até $1.300 \mathrm{~m}$ de profundidade. Vivípara ovofágica, aparentemente sem canibalismo intra-uterino (adelfofagia). Nascem cerca de nove filhotes por parto, com poucas fêmeas grávidas conhecidas. Alimenta-se de grande diversidade de organismos marinhos. Apresenta uma variação ontogenética na alimentação: exemplares com cerca de 2,5 m de CT preferem peixes ósseos demersais e elasmobrânquios e espécimes com mais de três m preferem mamíferos marinhos, principalmente pinípedes (ex. leão-marinho, foca), mas também pequenos cetáceos odontocetos (ex. golfinho) e carcaças de grandes baleias.

Observações: considerada no mundo como a mais perigosa das espécies de tubarão, pelo menos estatisticamente, com 236 casos de ataques a humanos computados até 2007. São conhecidas cerca de 25 ocorrências de tubarão-branco na costa brasileira. A maioria dos registros se deu na costa do Estado do Rio de Janeiro, e esse fato deve estar associado ao fenômeno da ressurgência na região de Cabo Frio e Arraial do 
Cabo durante o verão. São pelo menos nove as ocorrências confirmadas, (incluindo três ataques a humanos) e listadas a seguir: 1) um exemplar foi exposto no mercado público da Praça XV - Rio de Janeiro, com comprimento total estimado de seis metros em 1907; 2) em 1931, um exemplar de cerca de 5,2 m, foi capturado em uma rede de emalhe próximo a praia em Barra de Guaratiba, Rio de Janeiro; 3) em Angra dos Reis, Rio de Janeiro, em 1968, um tubarão-branco com mais de quatro metros foi capturado por arpão; 4) um exemplar com cerca de 5,4 m, capturado com anzol e linha durante o verão de 1970 em Atafona-Rio de Janeiro; 5) em Saquarema- Rio de Janeiro, em janeiro de 1974, um espécime de quatro metros de comprimento foi capturado, numa rede de emalhe a $30 \mathrm{~m}$ da praia; 6) novamente em Atafona-RJ, durante o verão de 1980, um exemplar com cerca de quatro metros foi capturado com anzol e linha; 7) foi registrado um ataque não fatal contra um mergulhador na Praia do Forte em Cabo Frio-Rio de Janeiro, em fevereiro de 1981; 8) registro de um ataque não fatal contra um windsurfista, em abril de 1997 em Búzios- Rio de Janeiro; e 9) relatado um ataque não fatal contra um mergulhador em Quissamã-Rio de Janeiro, em janeiro de 2002.

Considerada espécie em perigo de extinção para o município do Rio de Janeiro, de acordo com a listagem de fauna ameaçada em extinção (Buckup et al., 200o),

\section{Gênero Lamna}

Caracterizado por apresentar dentes com cúspides secundárias, menos evidentes em exemplares jovens; origem da primeira nadadeira dorsal sobre a inserção ou sobre as margens internas das nadadeiras peitorais (Fig. 107); origem da segunda nadadeira dorsal sobre a origem da nadadeira anal (Figs. 107 e 109); crista dérmica secundária presente no lobo inferior da nadadeira caudal (Fig. 102). Duas espécies conhecidas, mas apenas uma no litoral brasileiro (Lamna nasus).

Lamna nasus (Bonnaterre, 1788) (Fig. 107)

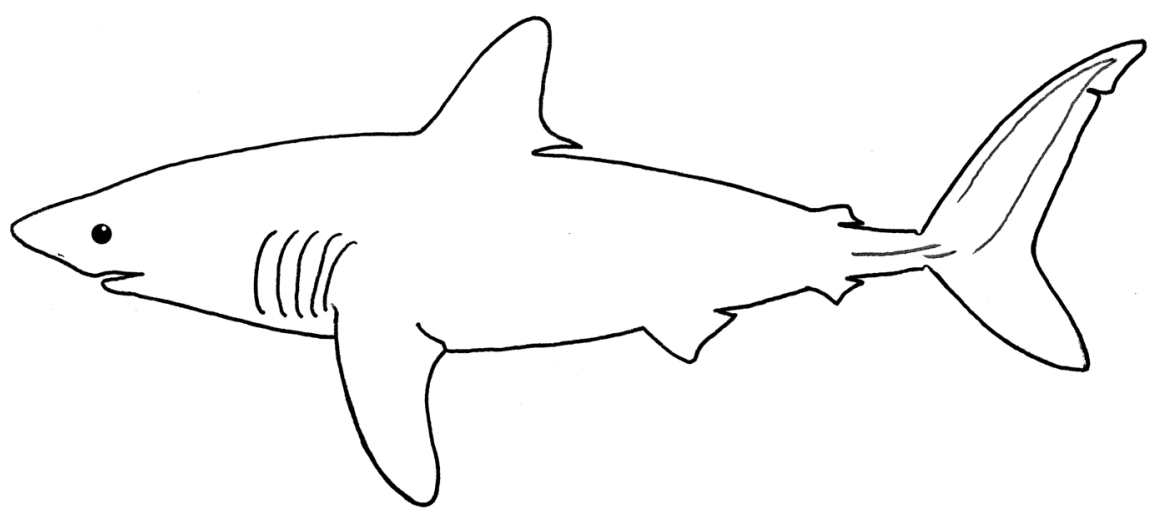

Nomes populares: tubarão-golfinho, tubarão-cavala. 
Caracteres distintivos: dentes estreitos e com margens lisas; espiráculos, quando presentes, são como poros diminutos atrás dos olhos; distância da ponta do focinho até a margem anterior do olho equivale a aproximadamente metade ou menos da distância da margem posterior do olho até a primera fenda branquial. Coloração do dorso castanha a cinza-azulada; primeira nadadeira dorsal com margem livre esbranquiçada; jovens exibem manchas cinzentas na face ventral das nadadeiras peitorais e região ventral da área branquial; ventre branco sem manchas escuras.

Tamanho: comprimento total máximo estimado de pelo menos três metros; machos maduros com cerca de 1,5 m de CT e fêmeas, entre 1,6 e 1,8 metros de CT. Nascem medindo entre 60 e $75 \mathrm{~cm}$ de CT.

Distribuição, Hábitos e Biologia: distribuição costeira e oceânica em todos os oceanos. As capturas no Brasil são ocasionais, mas eventualmente alguns exemplares são pescados pelos espinheleiros que atuam na área oceânica do Sudeste e Sul, com maior abundância aparentemente no Sul. Vive até cerca de $350 \mathrm{~m}$ de profundidade, preferencialmente em águas frias ( $2^{\circ}$ a $18^{\circ} \mathrm{C}$ ). Vivípara ovofágica, mas sem canibalismo intra-uterino. Nascem de um a cinco filhotes. Alimentam-se de cefalópodes, grande variedade de peixes ósseos pelágicos e pequenos elasmobrânquios.

Observações: o registro de ocorrência dessa espécie para área de estudo tem base em um exemplar, guardado no Museu Oceanográfico do Instituto de Estudos do Mar Almirante Paulo Moreira (IEAPM), em Arraial do Cabo.

\section{Gênero Isurus}

Apresenta dentes sem cúspides secundárias; origem da primeira nadadeira dorsal posterior às margens internas das nadadeiras peitorais; origem da segunda nadadeira dorsal anterior à origem da nadadeira anal; crista dérmica secundária ausente no lobo inferior da nadadeira caudal. Conhecidas duas espécies no mundo, Isurus oxyrinchus e I. paucus, ambas ocorrentes em toda a costa do Brasil. Uma terceira forma ("marrajo-criollo"), foi encontrada em áreas oceânicas adjacentes ao Arquipélago dos Açores, o Atlântico Norte oriental. Pelo que se sugere, tem morfologia similar a de I. oxyrinchus, mas padrão cromático de I. paucus.

\section{Chave para Identificação das Espécies do Gênero Isurus}

1a. Comprimento da nadadeira peitoral menor que a distância entre a ponta do focinho e a quinta fenda branquial (Fig. 108); origem da nadadeira anal aproximadamente localizada sob a metade da base da segunda nadadeira dorsal (Fig. 108); dorso azul metálico e ventre branco

I. oxyrinchus

1b. Comprimento da nadadeira peitoral maior que a distância entre a ponta do focinho e a quinta fenda branquial (Fig. 109); origem da nadadeira anal sob a inserção da 
segunda nadadeira dorsal (Fig. 109); dorso negro e manchas cinza na face ventral do focinho

I. paucus

Isurus oxyrinchus Rafinesque, 1810 (Fig. 110)

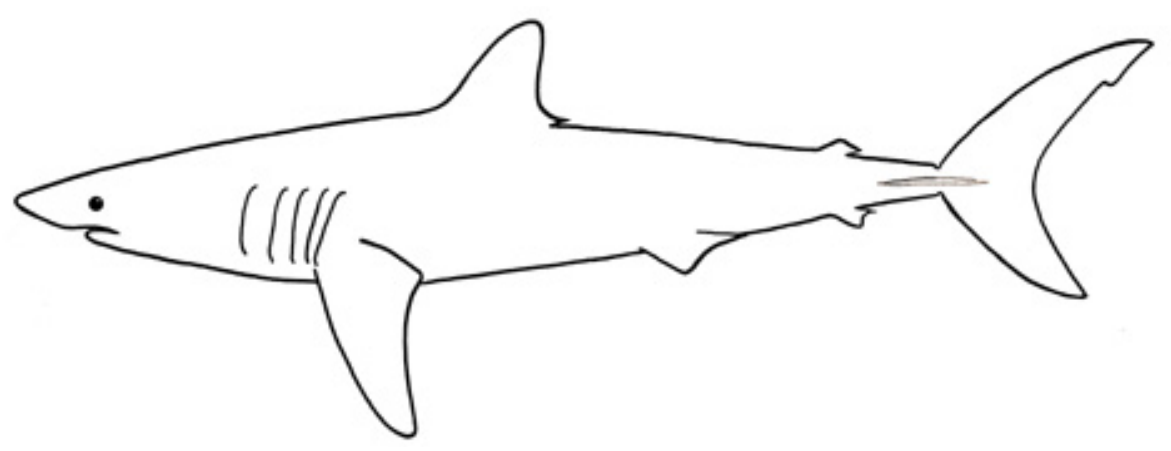

Nomes populares: anequim, mako.

Caracteres distintivos: diâmetro horizontal do olho cabe três vezes na região préoral; espiráculos em forma de poros ou fendas diminutas, localizados atrás dos olhos; nadadeiras peitorais longas, mas com seu comprimento menor do que a distância da ponta do focinho à quinta fenda branquial; origem da nadadeira anal mais ou menos sob a metade da base da segunda nadadeira dorsal. Coloração do dorso azul metálica intensa, tornando-se azul claro lateralmente; ventre completamente branco.

Tamanho: CT máximo de aproximadamente quatro metros; machos tornam-se sexualmente maduros a partir de 1,95 $\mathrm{m}$ de CT, e fêmeas, com cerca de dois $\mathrm{m}$ de CT. Nascem com cerca de $70 \mathrm{~cm}$ de CT.

Distribuição, Hábitos e Biologia: espécie cosmopolita, distribuída nas plataformas continentais e nas zonas oceânicas de todo o mundo. Encontrada em toda a costa brasileira, principalmente nas áreas oceânicas, onde é freqüentemente capturada pelos barcos espinheleiros. Na costa Sudeste e Sul, existem alguns registros de sua aproximação da área litorânea durante o verão, incluindo episódios de animais encalhados (Rio de Janeiro e São Paulo, no verão, pelo menos quatro na década de 90). Animal ativo, nada velozmente e chega, às vezes, a dar saltos para fora d'água. Vivípara ovofágica, sem adelfofagia (canibalismo intrauterino). Produz de quatro a 25 filhotes por parto. Alimentação constituída de invertebrados, grande variedade de peixes ósseos, tartarugas e pequenos cetáceos.

Observações: apesar de ser considerada uma espécie potencialmente perigosa, devido a casos de ataques a humanos registrados ao redor do mundo, não há oficialmente nenhum caso de ataque comprovado por essa espécie em águas brasileiras. 


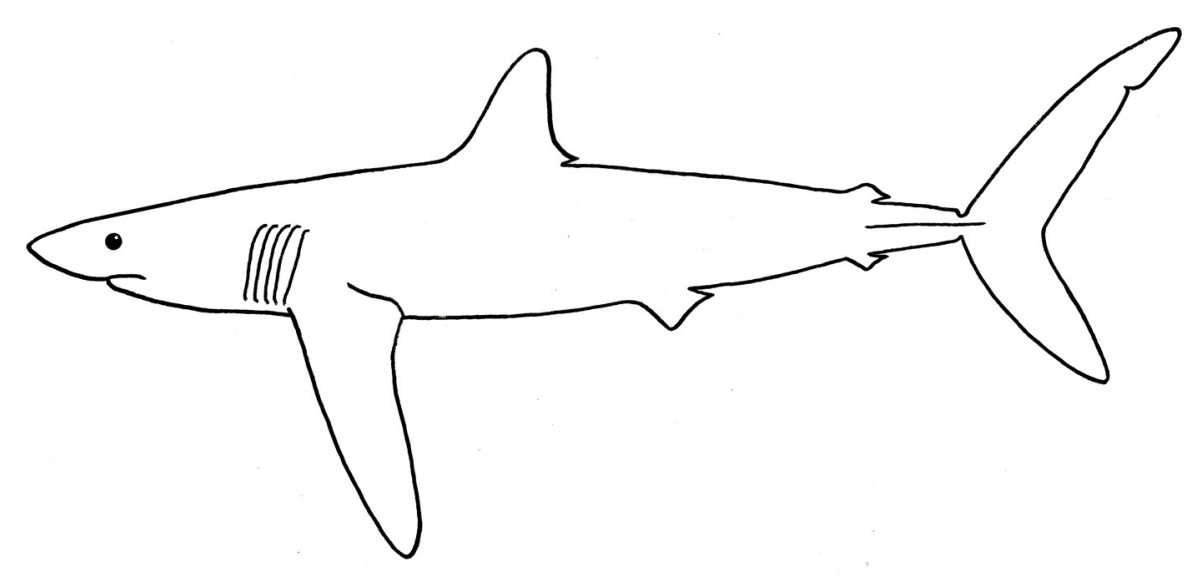

Nomes populares: anequim-preto, mako, mestiço.

Caracteres distintivos: nadadeiras peitorais muito longas, com seu comprimento maior do que a distância da ponta do focinho à quinta fenda branquial; origem da nadadeira anal sob a inserção da segunda nadadeira dorsal. Coloração dorsal negra e intensa podendo, às vezes, exibir alguns tons azulados; região ventral do corpo é mais clara, com manchas escuras espalhadas pela margem das nadadeiras peitorais e região ventral da cabeça, inclusive ao redor da boca.

Tamanho: CT máximo registrado de 4,17 m; estima-se que nasçam com cerca de 95 cm de CT.

Distribuição, Hábitos e Biologia: distribuição em todos os oceanos, associada a águas tropicais e subtropicais. Não é tão comum, havendo poucos registros ao largo da área oceânica da costa do Nordeste e Sul do Brasil. Aparentemente vive em águas mais profundas que $I$. oxyrinchus. Dão a luz a um ou dois filhotes por gestação. Alimentação constituída de moluscos cefalópodes e peixes ósseos.

Observações: até o presente não há registros formais da ocorrência dessa espécie no Estado do Rio de Janeiro, mas em função da sua ampla distribuição espacial ao largo de toda a área oceânica do Brasil, certamente essa espécie também ocorre nessa área. Talvez seu registro dependa de maior esforço amostral. Ainda assim, essa espécie é aparentemente mais rara, e vive em profundidades maiores quando comparada à sua congênere, I. oxyrinchus.

\section{ORDEM ORECTOLOBIFORMES}

Caracteriza-se pela presença de uma projeção carnosa em forma de barbilhão na margem de cada abertura nasal; boca terminal conectada à narina e olhos situados posteriormente em relação ao canto da boca. São conhecidas sete famílias no mundo e apenas duas no Oceano Atlântico, incluindo o Brasil (Ginglymostomatidae e Rhincodontidae). A maioria delas é demersal, habitante de substratos consolidados, 
como as formações recifais do Indo-Pacífico, exceto por Rhincodon typus, que é pelágica e de distribuição mundial. A relativa escassez de espécies dessa ordem no Atlântico relaciona-se ao fato de que o grupo é representado por muitas espécies associadas a recifes de coral, ecossistema relativamente pobre no Atlântico.

\section{Chave para Identificação das Famílias da Ordem Orectolobiformes}

1a. Sem crista dérmica lateral no pedúnculo caudal e nos flancos do corpo (Fig. 112, setas A e B); barbilhão nasal bem desenvolvido (Fig. 112, seta C) ........Ginglymostomatidae 1b. Com crista dérmica lateral no pedúnculo caudal e nos flancos do corpo (Fig. 113, setas A e B); barbilhão nasal pouco desenvolvido(Fig. 113, seta C).........Rhincodontidae

\section{Família GINGLYMOSTOMATIDAE}

Pedúnculo caudal sem cristas dérmicas laterais; flancos do corpo sem cristas longitudinais; nadadeira caudal com lobo inferior pouco desenvolvido em relação ao superior, o qual possui lobo subterminal; sulcos naso orais presentes; barbilhão nasal proeminente e bem visível. Três gêneros e três espécies conhecidas no mundo, um deles (Ginglymostoma) no Brasil.

\section{Gênero Ginglymostoma}

Apresenta a quarta e quinta fendas branquiais bastante próximas (Fig. 114); espiráculo pequeno e no mesmo nível do olho (Fig. 114); dentes iguais em ambas as arcadas, com muitas cúspides, sendo a central a maior; muitas fileiras de dentes funcionais; primeira nadadeira dorsal se origina sobre a origem da nadadeira pélvica. Existe apenas uma espécie reconhecida no mundo, Ginglymostoma cirratum, mas possivelmente há outra a ser descrita.

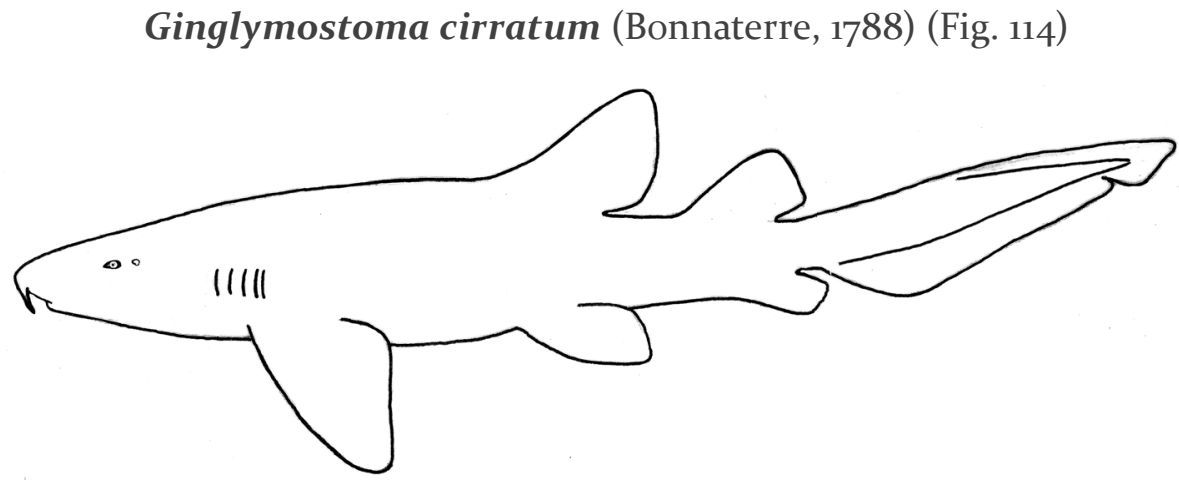


Nomes populares: cação-lixa, lambarú, urumarú.

Caracteres distintivos: barbilhões nasais moderadamente longos, chegando até a boca; sulcos nasorais presentes; olhos posteriores aos cantos da boca; espiráculos diminutos presentes no mesmo nível do olho; quarta e quinta fendas branquiais muito próximas entre si e quase sobrepostas; nadadeiras com ápices arredondados; segunda nadadeira dorsal menor que a primeira; nadadeira caudal alongada, correspondendo a cerca de 1/4 do CT; lobo subterminal da nadadeira caudal presente. Coloração do dorso variando entre castanho claro e escuro, ventre mais claro; neonatos e jovens apresentam pintas escuras que desaparecem ao longo do crescimento.

Tamanho: CT do adulto cerca de três metros; machos maduros a partir de 2,15 m, e fêmeas, entre 2,2 e 2,3 m; nascem com o tamanho aproximado de 28 a $31 \mathrm{~cm}$ de CT.

Distribuição, Hábitos e Biologia: ocorrem em águas tropicais e subtropicais do Oceano Atlântico e Pacífico Oriental. No Brasil, é mais abundante na costa Norte e Nordeste, e sua área limítrofe de distribuição localiza-se entre os Estados de São Paulo e Paraná. Espécie costeira de hábitos associados ao substrato de águas rasas, ocorre desde a zona entremarés, onde predominam os menores exemplares, até a profundidade de $70 \mathrm{~m}$, onde permanecem os maiores. Vivípara lecitrotrófica, nascendo de vinte a 50 filhotes por parto. Alimenta-se basicamente de invertebrados bentônicos (crustáceos, equinodermas e moluscos) e peixes ósseos.

Observação: é considerada extinta para o município do Rio de Janeiro, de acordo com a listagem de fauna ameaçada em extinção, embora tenha sido recentemente fotografado um exemplar no nas ilhas Cagarras (em frente à capital fluminense), e de registros recentes desta espécie no litoral norte de São Paulo (Buckup et al., 200o).

\section{Família RHINCODONTIDAE}

Presença de crista dérmica lateral no pedúnculo caudal; flancos do corpo com cristas longitudinais proeminentes; nadadeira caudal sem lobo subterminal; sulcos nasorais ausentes; barbilhão nasal rudimentar e pouco visível. Apresenta apenas um gênero e uma espécie (Rhincodon typus), sendo amplamente distribuída no mundo. Essa família é a única representante da ordem Orectolobiformes de distribição mundial, e que exibe hábitos pelágicos.

\section{Gênero Rhincodon}

A primeira nadadeira dorsal origina-se anteriormente à nadadeira pélvica; fendas branquiais desenvolvidas (segunda e terceira fendas são as mais longas), alcançando quase a crista dérmica longitudinal mais inferior dos flancos. Popularmente chamado de "tubarão-baleia", é o maior peixe conhecido, chegando aos $20 \mathrm{~m}$ de CT. 


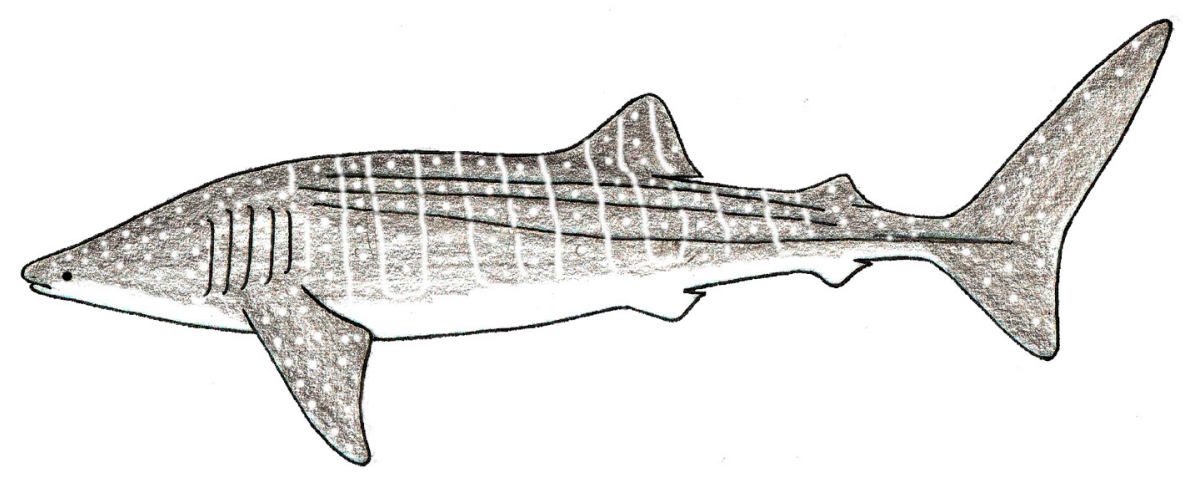

Nomes populares: tubarão-baleia, pintadinho, cação-estrela.

Caracteres distintivos: boca tão larga quanto a largura da cabeça, e quase terminal; corpo com três cristas longitudinais nos flancos; a mais inferior termina em uma crista dérmica lateral no pedúnculo da cauda; barbilhão nasal rudimentar; dentes diminutos e numerosos, com forma de gancho; espiráculos vestigiais. Coloração do dorso castanha, com pintas brancas de variados tamanhos, mais numerosas e menores na região dorsal da cabeça, formando estrias transversais nos flancos; ventre claro.

Tamanho: maior espécie de elasmobrânquio, podendo atingir 20 m de CT (um único exemplar dessas dimensões foi encontrado, pesando 36 toneladas); a maioria, no entanto, chegando a menos de $13 \mathrm{~m}$ de CT; maturidade sexual estimada em sete a oito metros de CT; nasce com cerca de 50 a 60 cm de comprimento. Uma fêmea capturada em junho de 1995, na Praia Grande, Arraial do Cabo (RJ), mediu 9,86 m de CT.

Distribuição, Hábitos e Biologia: ocorre em todo o mundo, normalmente em águas tropicais e subtropicais. No Brasil são conhecidos cerca de 60 registros. Espécie oceânico-costeira, vive geralmente nas camadas superficiais da coluna d'água, podendo estar associada a regiões com alta produtividade primária. Uma fêmea capturada em Taiwan foi encontrada com trezentos embriões. Alimenta-se de uma grande variedade de organismos planctônicos e nectônicos (pequenos cardumes de peixes ósseos e ocasionalmente peixes maiores), consumidos por sucção e filtração.

Observações: os registros dessa espécie no Rio de Janeiro estão listados a seguir: 1) fevereiro de 1983, na plataforma petrolífera "Garoupa", ao largo da costa do Rio de Janeiro, um exemplar com cerca de dez metros foi avistado nadando em profundidade de aproximadamente 30 metros; 2) 27 de março de 1984, uma fêmea de 10,2 metros morreu encalhada na Praia Grande, Arraial do Cabo; 3) em fevereiro de 1992, na Plataforma petrolífera "Vermelho", ao largo da costa do Rio de Janeiro, um animal foi avistado; 4) 21 de maio de 1993, na Praia Grande, Arraial do Cabo, uma fêmea com pouco mais de dez metros encalhou na praia e morreu um dia depois, apesar dos esforços de populares em devolvê-la ao mar; 5) dias depois, em 27 de maio de 1993, também na Praia Grande, Arraial do Cabo, outra fêmea de tamanho similar encalhou, mas desta vez foi salva com a ajuda de pescadores e da Marinha do Brasil; 
6) em junho de 1994, na Plataforma petrolífera "Enchova", ao largo da costa do Rio de Janeiro, um exemplar foi observado durante cerca de quinze dias; 7) novembro de 1994, na Plataforma de Petróleo P-17, ao largo da costa do Rio de Janeiro, um animal foi avistado; 8) em 18 de março de 1995, Angra dos Reis, um tubarão-baleia com tamanho estimado de oito metros de comprimento foi avistado por mergulhadores, a 12 m de profundidade, próximo de um naufrágio; 9) o2 de junho de 1995, novamente na Praia Grande, Arraial do Cabo, ocorreu outro encalhe que resultou em morte, de uma fêmea medindo 9,86 metros. 16 de agosto de 1997, na praia de Monsuaba, Angra dos Reis, um animal com sete metros foi avistado de uma embarcação; 11) 28 de agosto de 1997, praia dos Cavaleiros, Macaé, um espécime com cerca de nove metros encalhou já em estado de putrefação; 12) em 2 de janeiro de 2001, em Quissamã, um animal com tamanho estimado em dez metros e pesando cerca de cinco toneladas, foi capturado com rede-de-emalhar durante a noite; 13) um mês depois, em o2 de fevereiro de 2001, novamente em Quissamã, um exemplar com cerca de dez metros foi capturado com rede-de-emalhar; e 14) em abril de 2005, em Arraial do Cabo, foi avistado um exemplar com tamanho estimado em dez metros, aproximadamente a 25 metros de profundidade. A maioria dos registros no Sudeste brasileiro, com concentração entre Rio de Janeiro e norte de São Paulo, pode estar relacionada ao fenômeno da ressurgência que ocorre em Cabo Frio (RJ).

Espécie considerada criticamente em perigo para o município do Rio de Janeiro, de acordo com a listagem de fauna ameaçada em extinção (Buckup et al. 200o). O tubarão-baleia é protegido legalmente em muitas regiões do mundo.

\section{ORDEM CARCHARHINIFORMES}

Têm como característica principal a presença de membranas nictitantes retráteis protegendo os olhos, podendo ser rudimentares ou bem desenvolvidas. São amplamente distribuídos em todos os oceanos, encontrados em regiões costeiras e oceânicas desde a superfície até grandes profundidades. Uma das espécies (o tubarão-cabeça-chata, Carcharhinus leucas) pode penetrar ativamente em água doce. Apresentam CT variando de $30 \mathrm{~cm}$ (Eridacnis radcliffei Smith, 1913) a cerca de 5,5 m (Galeocerdo cuvier Péron \& LeSueur, 1822). É o maior grupo de tubarões, com um total de 216 espécies distribuídas em oito famílias e 48 gêneros. Na costa do Estado do Rio de Janeiro, está representado por quatro famílias, 12 gêneros e 35 espécies.

\section{Chave para Identificação das Famílias da Ordem Carcharhiniformes}

1a. Origem da primeira nadadeira dorsal situada sobre ou posterior à origem das nadadeiras pélvicas (Fig. 116, seta). Scyliorhinidae 
1b. Origem da primeira nadadeira dorsal situada anteriormente à origem das nadadeiras pélvicas (Fig. 117, seta).

2

2a. Cabeça expandida lateralmente, como um martelo (Fig. 118).............. Sphyrnidae

2b. Cabeça não expandida lateralmente, sem forma de martelo (Fig. 119)...................... 3

3a. Com membranas nictitantes desenvolvidas nos olhos (Fig. 120); com sulco précaudal no pedúnculo caudal (Fig. 122, seta).

Carcharhinidae

3b. Com membranas nictitantes rudimentares nos olhos (exceto em Galeorhinus) (Fig. 121); sem sulco pré-caudal no pedúnculo caudal (Fig. 123, seta).

Triakidae

\section{Família SCYLIORHINIDAE}

Seus representantes diferem dos demais membros da ordem Carcharhiniformes por apresentarem a origem da primeira nadadeira dorsal posterior ou sobre a origem das nadadeiras pélvicas. São encontrados em várias partes do mundo, desde águas tropicais até águas temperadas, normalmente em grandes profundidades próximos ao talude continental, sobre ou junto ao fundo. Muitos gêneros apresentam distribuição restrita, com muitas áreas de endemismo. A estratégia reprodutiva se faz, em sua maioria, por oviparidade. É a maior família de tubarões, com 16 gêneros e 105 espécies em todo o mundo. No Estado do Rio de Janeiro, encontra-se representada por apenas quatro gêneros (Scyliorhinus, Apristurus, Parmaturus e Galeus). A identificação das espécies de Scyliorhinidae é muito complicada e ainda não está satisfatoriamente esclarecida no Brasil. É possível que em águas mais profundas da costa do Rio de Janeiro ocorram outros gêneros.

Observação: Baseado em estudos moleculares foi designada a família Pentanchidae, para inculir os outrora scyliorhinídeos dos gêneros Apristurus, Bythyalurus, Cephalurus, Figaro, Galeus, Halaelurus, Hapoblepharus, Holohaelurus, Parmaturus e Pentanchus (Human et al 2006, Naylor et al., 2012). Considerando os argumentos de Soares et al., (2019), que teve como base a classificação de Compagno $(1984,1988)$ e sendo detalhadamente baseada em estudos anatômicos e morfológicos, preferimos deixar Galeus, Parmaturus e Apristurus como pertencentes à família Scyliorhinidae.

\section{Chave para Identificação dos Gêneros da Família Scyliorhinidae}

1a. Crista supra-orbital presente, perceptível ao tato (Fig. 124, setas); coloração do corpo com selas dorsais escuras, pintas escuras e/ou claras..... 2 1b. Crista supra-orbital ausente (Fig. 125, seta); coloração do corpo uniforme, sem selas e pintas escuras e /ou claras. 3 
2a. Segunda nadadeira dorsal do mesmo tamanho que a primeira nadadeira dorsal (Fig. 138)

Schroederichthys

2b. Segunda nadadeira dorsal menor que a primeira nadadeira dorsal (Fig. 132).

Scyliorhinus

3a. Coloração escura; cabeça achatada; focinho espatulado, comprido, maior que a largura da boca (Fig. 126, setas A e B)

Apristurus

3b. Coloração clara-uniforme ou com manchas; cabeça não achatada; focinho arredondado, curto, menor que a largura da boca (Fig. 127, setas A e B).... 4

4a. Coloração com manchas (Fig. 128); nadadeira peitoral relativamente grande: largura da margem posterior geralmente maior que a largura da boca.....

Galeus

4b. Coloração sem manchas (Fig. 129); nadadeira peitoral pequena: largura da margem posterior geralmente menor que a largura da boca.....

Parmaturus

\section{Gênero Scyliorhinus}

Caracteriza-se por apresentar crista supra-orbital (perceptível ao toque); sulco labial superior vestigial ou ausente; coloração do corpo com selas escuras dorsais, com pintas escuras e/ou claras (Figs. 132 a 134). Esse grupo é composto até o presente por 17 espécies em todo o mundo, e o gênero Scyliorhinus é representado em águas fluminenses por três espécies, ainda não conhecidas satisfatoriamente do ponto de vista biológico (Scyliorhinus haeckelii, S. ugoi e Scyliorhinus cabofriensis). Além da coloração, essas espécies são identificadas e diferenciadas por caracteres internos, como a morfologia do crânio, dos órgãos copuladores e morfometria. Possivelmente há mais uma espécie não descrita, que deve ocorrer em área adjacente.

\section{Chave para Identificação das Espécies do Gênero Scyliorhinus}

1a. Corpo de aspecto geral claro; selas com bordas pouco evidentes; as selas pré-dorsais não apresentam projeções medianas anteriormente ou posteriormente (Fig. 130, seta); pintas negras predominantes e variadas, concentradas nas selas ou espalhadas irregularmente sobre o dorso nas selas e interselas (podem ocorrer pintas claras muito pequenas).

1b. Corpo de aspecto geral escuro; selas com bordas bem evidentes; as selas prédorsais apresentam projeções medianas pontudas anteriormente e posteriormente (Fig. 131, seta); pintas claras grandes, habitualmente concentradas dentro das selas; (Fig. 134)

Scyliorhinus ugoi

2a. Pontuações negras predominantemente concentradas nas selas; pontuações negras em forma de foice ou semi-círculo ao longo da região superior e lateral do corpo, e abaixo das selas e interselas (Fig. 132, limites tracejados) Scyliorhinus haeckelii 
2b. Pontuações negras uniformemente distribuídas nas selas e interselas de forma contínua; pontuações negras em forma de foice ou semi-círculo ao longo da região lateral do corpo, e predominantemente abaixo das selas e interselas (Fig. 133, limites tracejados).

Scyliorhinus cabofriensis

Scyliorhinus haeckelii Miranda Ribeiro, 1907 (Fig. 132)

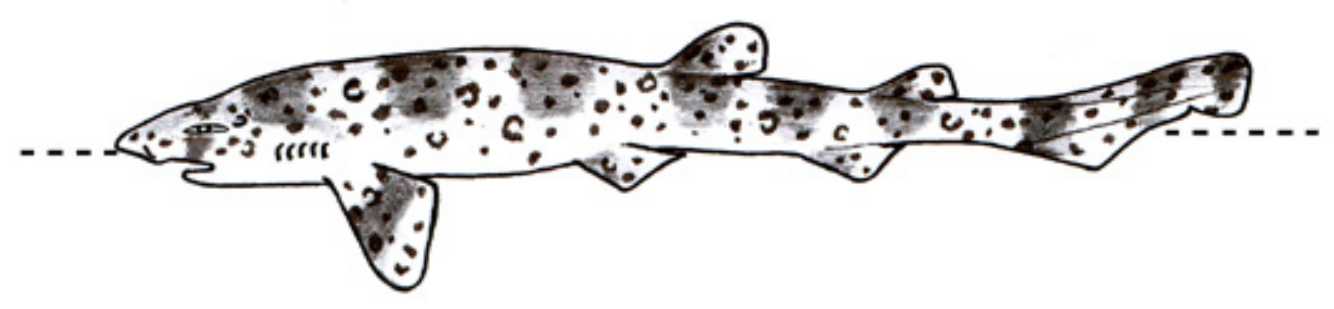

Nomes populares: cação-pintado, cação-gato, cação-pinto, pintadinho, caçãooncinha.

Caracteres distintivos: Coloração de fundo do corpo clara. Coloração dorsal muito variável: possuem pintas negras de vários tamanhos. Alguns formatos de semicirculos também aparecem ao longo da região superior e lateral do corpo, e abaixo das selas e interselas. Pintas brancas também podem estar presentes. O ventre é claro.

Tamanho: atinge cerca de $60 \mathrm{~cm}$ de CT; exemplares machos com $37 \mathrm{~cm}$ CT são adultos; as fêmeas com 41,7 cm de CT já carregam cápsulas ovígeras; nascem com tamanho estimado de $13 \mathrm{~cm}$ de CT.

Distribuição, Hábitos e Biologia: Atlântico Ocidental, desde o norte do Rio de Janeiro até a Argentina, em profundidades variando de 37 a 402 metros, geralmente em fundos coralinos ou calcários. Reprodução ovípara, produzindo duas cápsulas ovígeras, uma por oviduto, de coloração clara, amarelada e sem estrias longitudinais. As cápsulas ovígeras dessa espécie medem cerca de seis centímetros de comprimento por dois centímetros de largura. Foram encontrados peças bucais de lulas e pequenos peixes ósseos no conteúdo estomacal.

Observações: $S$. haeckelii e $S$. besnardi foram consideradas, por muito tempo, espécies diferentes principalmente com base no padrão de coloração. Proporções corporais não separavam essas espécies. Recentemente com o trabalho de Soares, Gomes e Carvalho (2016), considerando a anatomia craniana e o esqueleto dos órgãos copuladores, verificaram ser uma única espécie: $S$. haeckelii (S. besnardi passou a sinônimo júnior). Considerada "vulnerável" para o município do Rio de Janeiro, de acordo com a listagem de fauna ameaçada em extinção (Buckup et al., 2000). 


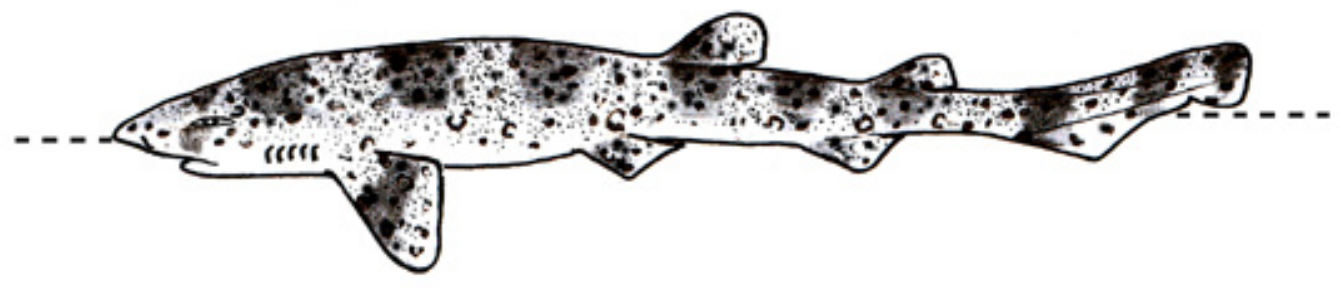

Nomes populares: cação-pintado, cação-gato, pintadinho.

Caracteres distintivos: Coloração de fundo do corpo clara. Pontuações negras uniformemente distribuídas nas selas e interselas de forma contínua; pontuações negras em forma de foice ou semi-círculo ao longo da região lateral do corpo e abaixo das selas e interselas, com presença de pintas brancas. O ventre é claro.

Tamanho: Há poucos exemplares conhecidos. Com $39 \mathrm{~cm}$ de CT o macho já é adulto. O maior macho dessa espécie mede $46,8 \mathrm{~cm}$ de CT. A maior fêmea conhecida tem 45 $\mathrm{cm}$ de CT, e com $31 \mathrm{~cm}$ de CT ainda é imatura.

Distribuição, Hábitos e Biologia: Até o presente esta espécie tem registro no Atlântico Sul Ocidental, apenas em Cabo Frio e imediações. Tem hábitos demersais e reproduz-se por oviparidade.

Scyliorhinus ugoi, Soares, Gadig \& Gomes. 2015 (Fig. 134)

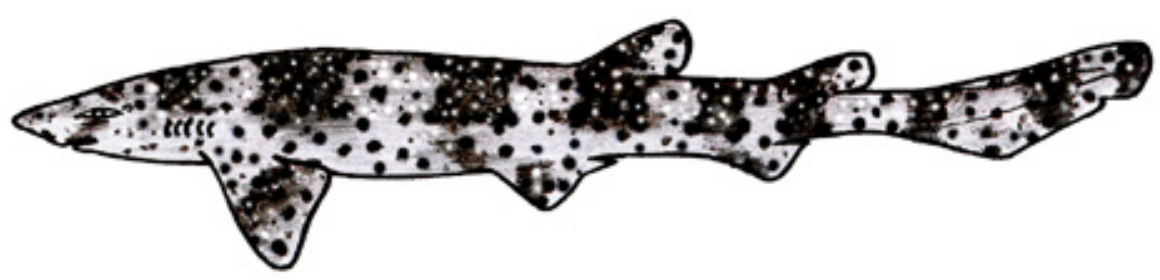

Nomes populares: cação-pintado, cação-gato, pintadinho.

Caracteres distintivos: Coloração de fundo do corpo escura. Selas com bordas bem evidentes, onde as selas anteriores à primeira nadadeira dorsal apresentam uma projeção mediana pontiaguda anterior e posterior. Poucas pintas claras estão habitualmente concentradas dentro das selas. Ventre escuro.

Tamanho: Dos poucos exemplares conhecidos, todos são adultos. O maior macho registrado mediu $53 \mathrm{~cm}$ de CT e a maior fêmea, $60 \mathrm{~cm}$ de CT.

Distribuição, Hábitos e Biologia: encontrada no Oceano Atlântico Sul Ocidental. No Brasil, há exemplares do litoral de Pernambuco, Alagoas, Bahia, Espírito Santo e norte do Rio de Janeiro. Espécie de hábitos demersais. Reproduz-se por oviparidade, desovando duas cápsulas ovígeras (uma por oviduto). Essas cápsulas têm cor âmbar, sem estrias longitudinais, e medem cerca de seis $\mathrm{cm}$ de comprimento, por dois $\mathrm{cm}$ de largura. Alimenta-se de invertebrados, pequenos peixes ósseos e, possivelmente, de animais mortos no substrato. 
Observações: aparentemente o Rio de Janeiro corresponde ao limite sul de distribuição dessa espécie.

\section{Gênero Apristurus}

Caracteriza-se por apresentar focinho achatado dorso-ventralmente; sem cristas supra-orbitais; sulco labial superior presente e bem desenvolvido, alcançando o nível da margem anterior da boca; coloração do corpo sem selas e uniformemente escura. É um dos grupos mais complexos do ponto de vista taxonômico, pois as cerca de 31 espécies conhecidas exibem morfologia externa muito semelhante. Além disso, vivem em grandes profundidades e muitas delas estão pobremente representadas em coleções científicas, dificultando as pesquisas de identificação. No Brasil, $A$. parvipinnis e $A$. profundorum foram registradas até o momento, mas podem ocorrer outras espécies em grandes profundidades.

\section{Chave para Identificação das Espécies do Gênero Apristurus}

1a. Primeira nadadeira dorsal menor que a segunda nadadeira dorsal; origem da primeira nadadeira dorsal atrás da inserção das nadadeiras pélvicas (Fig. 135)

Apristurus parvipinnis

1b. Primeira nadadeira dorsal do mesmo tamanho ou pouco maior que a segunda nadadeira dorsal; origem da primeira nadadeira dorsal sobre a metade da base das nadadeira pélvicas (Fig. 136)

Apristurus profundorum

Apristurus parvipinnis Springer \& Heemstra in Springer, 1979 (Fig. 135)

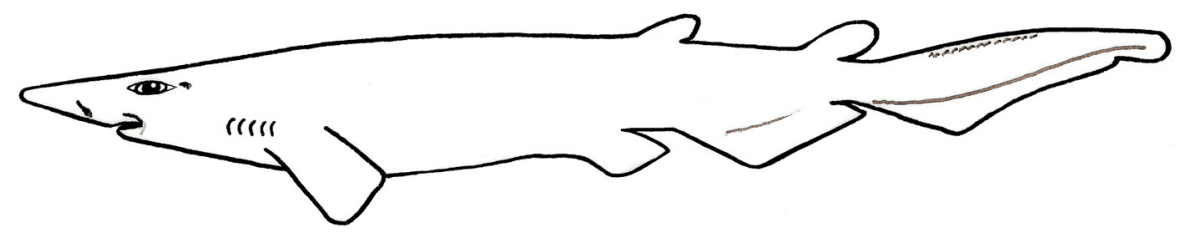

Nome popular: cação-espátula.

Caracteres distintivos: focinho achatado dorso-ventralmente e moderadamente curto, com distância pré-oral correspondendo a cerca de $10 \%$ do comprimento total; distância pré-nasal menor do que a distância interorbital; fendas branquiais menores que o diâmetro horizontal do olho; comprimento da fenda nasal semelhante à medida da distância internasal; sulco labial superior alcançando o nível da margem anterior da boca; espaço interdorsal maior que duas vezes o comprimento da base da primeira dorsal; primeira nadadeira dorsal muito menor que a segunda, sua base correspondendo a pouco mais da metade da base da segunda nadadeira dorsal; 
margem dorsal da nadadeira caudal com uma fileira de dentículos proeminentes. Coloração do dorso uniforme, castanha escura; ventre com tom mais escuro que o dorso.

Tamanho: atinge aproximadamente $52 \mathrm{~cm}$ de CT.

Distribuição, Hábitos e Biologia: encontrada no Oceano Atlântico Norte Ocidental, no Golfo do México, região do Caribe e América do Sul. No Brasil, há registros no Espírito Santo e Rio de Janeiro. É demersal, vivendo entre 600 e 1.220 $\mathrm{m}$ de profundidade. Ovípara, produz uma cápsula ovígera por oviduto. $\mathrm{O}$ regime alimentar é desconhecido, mas provavelmente preda pequenos invertebrados e peixes ósseos que habitam substrato de grandes profundidades.

Observações: até o momento, somente três exemplares são conhecidos no Brasil. Dentre eles, dois (um macho de $39 \mathrm{~cm}$ de CT e uma fêmea de 30,4 cm de CT) são provenientes do litoral do estado do Espírito Santo $\left(19^{\circ} 42^{\prime} \mathrm{S}-38^{\circ} 36^{\prime} \mathrm{W}\right)$, coletados com arrasto de fundo a $902 \mathrm{~m}$ de profundidade. O terceiro (macho adulto com 58,8 cm de (T), corresponde ao único registro no Estado do Rio de Janeiro, capturado a leste de Cabo Frio, entre outubro e novembro de 2004, em profundidade de 650 a $720 \mathrm{~m}$.

Apristurus profundorum (Goode \& Bean, 1896) (Fig. 136)

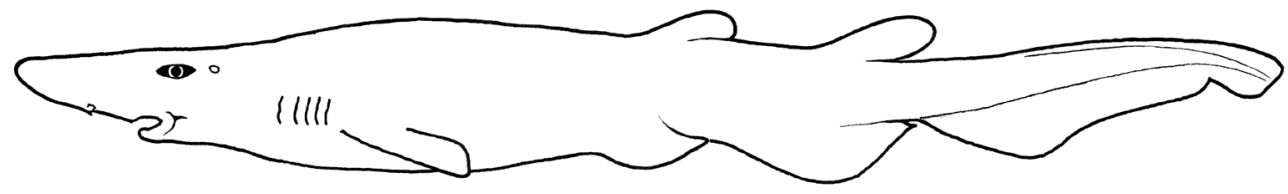

Nome popular: cação-espátula.

Caracteres distintivos: corpo delgado, focinho largo e achatado dorsoventralmente. Largura da narina equivale à distância internasal. Primeira nadadeira dorsal do mesmo tamanho ou pouco maior que a segunda nadadeira dorsal; origem da primeira nadadeira dorsal sobre a metade da base das nadadeiras pélvicas. Coloração do dorso uniforme, castanha escura; ventre com tom mais escuro.

Tamanho: é provável que ultrapassem os $50 \mathrm{~cm}$ de $\mathrm{CT}$, pois com esse tamanho o indivíduo é ainda jovem.

Distribuição, Hábitos e Biologia: Seus registros de ocorrência são esparsos, sendo encontrados na costa atlântica dos Estados Unidos e na Mauritânia (África). São coletados em locais com mais de $1400 \mathrm{~m}$ de profundidade.

Observações: Dois espécimens medindo entre 110,4 a $225 \mathrm{~mm}$ de CT foram registrados em águas profundas no norte do Rio de Janeiro, sendo a primeira ocorrência para o Brasil (Nunnan \& Senna, 2007). 


\section{Gênero Parmaturus}

Caracteriza-se por possuir um focinho arredondado e curto, menor do que a largura da boca. Corpo mole, primeira nadadeira dorsal posicionada acima das nadadeiras pélvicas, e segunda nadadeira dorsal posicionada acima da nadadeira anal. Coloração uniforme. Cerca de 13 espécies são conhecidas, encontradas na Austrália, Nova Zelândia, Nova Caledônia, China, Japão, Indonésia, Papua, Nova Guiné, Estados Unidos, México e Brasil. No Brasil, apenas uma espécie é conhecida, a recém descrita Parmaturus angelae.

Parmaturus angelae Soares, Carvalho, Schwingel e Gadig, 2019 (Fig. 137)

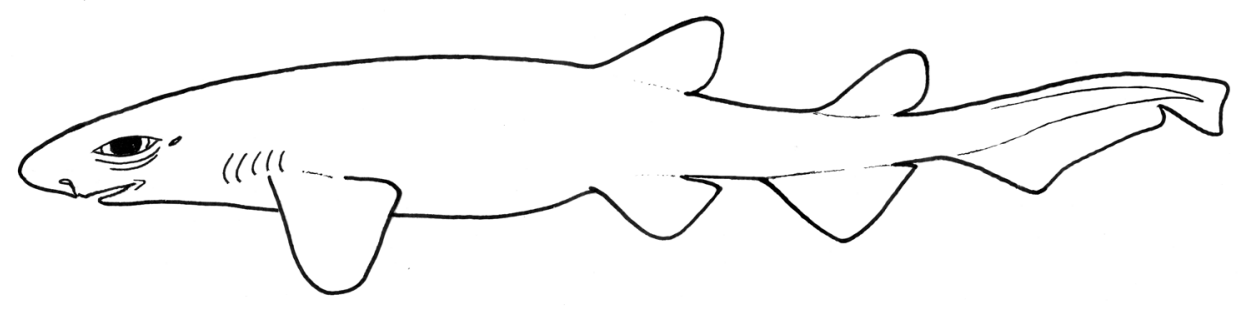

Nome popular: nome proposto pelos autores da espécie, cação-gato da Ângela.

Caracteres distintivos: coloração clara, bege; origem da primeira nadadeira dorsal anterior à origem da nadadeira pélvica; presença de dentículos dérmicos caudais superiores e inferiores formando cristas; nadadeiras dorsais subiguais; focinho arredondado; focinho mais curto que a largura da boca.

Tamanho: Os dois exemplares conhecidos medem respectivamente 398 e $425 \mathrm{~mm}$ de CT.

Distribuição, Hábitos e Biologia: Um registro em Santa Catarina e outro no Rio de Janeiro. Foram capturados na plataforma continental a uma profundidade de $600 \mathrm{~m}$ (SC) e 500 m (RJ) sendo considerada uma espécie demersal-bentônica.

Os dois exemplares mencionados são fêmeas maduras. O maior exemplar foi dissecado apresentando o ovário direito funcional. Foram encontradas cápsulas ovígeras de cor castanho-escura. Crustáceos, poliquetas e peixes ósseos foram encontrados no conteúdo estomacal.

Observações: Recentes estudos moleculares propuseram a separação dessa família. Como resultado vários gêneros, dentre os quais Apristurus e Parmaturus, passaram a pertencer à família Pentanchidae. Nelson et al. (2016) afirmam que essa modificação ainda é prematura, necessitando mais estudos genéticos e morfológicos. 


\section{Gênero Schroederichthys}

Caracteriza-se por apresentar a segunda nadadeira dorsal do mesmo tamanho que a primeira dorsal, focinho curto e arredondado, sulcos labiais superior e inferior presentes; coloração com selas e ou pontuações. São conhecidas quatro espécies: S. chilensis, S. maculatus, S. bivius, S. tenuis e, recentemente, S. saurisqualus. Esta última tem registro para o Rio de Janeiro.

Schroederichthys saurisqualus Soto, 2001 (Fig. 138)

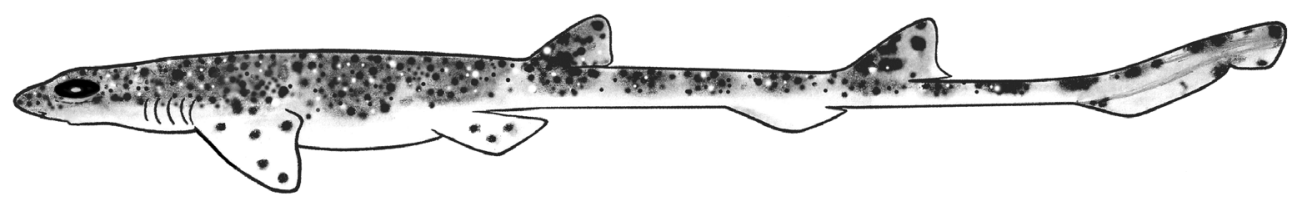

Nome popular: inexistente

Caracteres distintivos: Corpo robusto até a origem da primeira dorsal, quando então afina bruscamente em direção à nadadeira caudal. Lobo nasal digitiforme e proeminente; sulco labial superior maior que o inferior; origem da primeira nadadeira dorsal pouco atrás da axila das nadadeiras pélvicas; presença de pontuações pretas e brancas; dorso castanho com selas mais escuras transversais ao eixo do corpo; numerosas pintas claras e escuras; ventre claro.

Tamanho: machos atingem até $582 \mathrm{~mm}$ de CT, as fêmeas alcançam $692 \mathrm{~mm}$ de CT. Distribuição, Hábitos e Biologia: Aparentemente restrito ao Sul do Brasil (estados do Rio Grande do Sul até Santa Catarina), tendo sido capturada também em São Paulo, além de um registro de ocorrência no ano de 2004 em águas profundas do Rio de Janeiro. São encontradas em profundidades entre 122 a 435 metros. Espécie ovípara, com ovos de coloração cinza-oliva ou castanha. Alimentam-se de cefalópodes e peixes ósseos.

Obsevações: O Rio de Janeiro é o registro mais ao norte de ocorrência da espécie.

\section{Gênero Galeus}

Coloração com manchas; nadadeira peitoral relativamente grande, largura da margem posterior geralmente maior que a largura da boca. Margem dorsal do pedúnculo caudal e parte superior do lobo caudal com crista formada por dentículos dérmicos desenvolvidos. São conhecidas, até o presente, 18 espécies. 


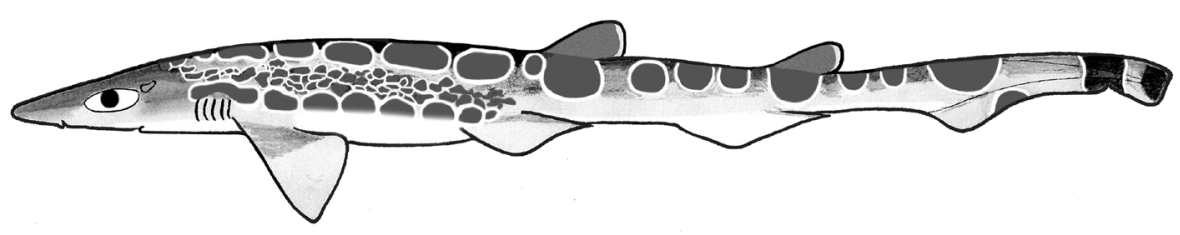

Nome popular: tubarão-lagarto, cauda-de-serra

Caracteres distintivos: Corpo delgado, segunda nadadeira dorsal ligeiramente mais larga que a primeira nadadeira dorsal. Origem da primeira nadadeira dorsal ligeiramente anterior à vertical que passa nas axilas das nadadeira pélvicas. Cauda com crista précaudal formada por escamas desenvolvidas. Escamas da lateral do tronco tricúspides. Coloração castanha avermelhada (material fresco) ou pálida (material fixado). Manchas arredondadas distribuídas pelo corpo. Ventre claro e uniforme, sem manchas.

Tamanho: $237 \mathrm{~mm}$ de CT (imaturos) até $404 \mathrm{~mm}$ de CT (adultos).

Distribuição, Hábitos e Biologia: Restrito ao Sul do Brasil (estados do Rio Grande do Sul e Santa Catarina), com um registro de ocorrência em águas profundas do Rio de Janeiro. Ovíparos, produzindo apenas um ovo por gestação. Provavelmente alimentam-se de peixes e moluscos.

\section{Família TRIAKIDAE}

Origem da primeira nadadeira dorsal anterior à origem das nadadeiras pélvicas; presença de membranas nictitantes rudimentares protegendo os olhos (exceto em Galeorhinus, que as têm mais desenvolvidas); ausência de sulco pré-caudal superior e inferior no pedúnculo caudal. Ocorrem em todos os oceanos, geralmente sobre a plataforma continental ou insular de mares temperados a tropicais. Vivem associados ao substrato e podem ser encontrados desde águas muito rasas até aproximadamente 2.00o m de profundidade. Representada por nove gêneros no mundo, porém apenas dois ocorrem no Brasil, e também no Rio de Janeiro (Mustelus e Galeorhinus).

\section{Chave para Identificação dos Gêneros da Família Triakidae}

1a. Crista dérmica interdorsal ausente (Fig. 140, seta); primeira nadadeira dorsal maior do que a segunda nadadeira dorsal (Fig. 142); nadadeira anal de tamanho similar ao da segunda nadadeira dorsal, comprimento de sua base cabe aproximadamente uma vez no comprimento da base da segunda nadadeira dorsal. Galeorhinus

1b. Crista dérmica interdorsal presente (Fig. 141, seta); nadadeiras dorsais com tamanhos similares (Fig. 143); nadadeira anal menor do que a segunda nadadeira 
dorsal, comprimento de sua base cabendo aproximadamente uma vez e meia no comprimento da base da segunda nadadeira dorsal

Mustelus

\section{Gênero Galeorhinus}

Sem crista dérmica interdorsal; primeira nadadeira dorsal maior do que a segunda nadadeira dorsal; nadadeira anal com tamanho aproximadamente igual ao da segunda nadadeira dorsal, comprimento de sua base cabe aproximadamente uma vez no comprimento da base da segunda nadadeira dorsal. Há apenas uma espécie no mundo, Galeorhinus galeus, que até alguns anos era considerada um complexo de espécies em diferentes áreas geográficas (ex., G. vitaminicus - no Atlântico Sul ocidental; G. zyopterus - No Pacífico oriental; G. australis - Indo-Pacífico; e G. galeus - Atlântico Norte oriental).

Galeorhinus galeus (Linnaeus, 1758) (Fig. 144)

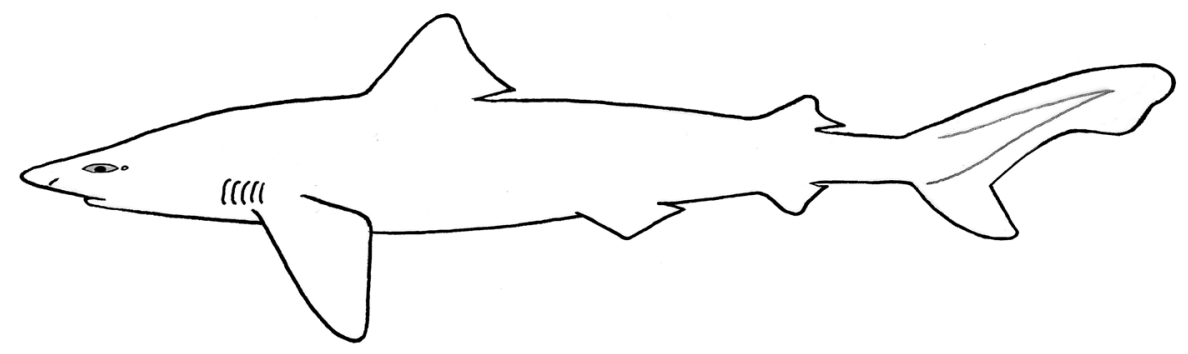

Nomes populares: cação bico-de-cristal; cação bico-doce.

Caracteres distintivos: focinho longo eligeiramentearredondado, com comprimento pré-oral equivalente à largura da boca, e correspondendo aproximadamente ao dobro da distância internasal; olhos com membranas nictitantes desenvolvidas; espiráculos presentes; dentes semelhantes em ambas as arcadas, subtriangulares, com uma cúspide oblíqua e três ou mais cúspides acessórias menores; origem da primeira nadadeira dorsal sobre ou posterior às margens internas das nadadeiras peitorais; sem crista dérmica interdorsal; primeira nadadeira dorsal maior do que a segunda nadadeira dorsal; origem da segunda nadadeira dorsal pouco anterior à origem da nadadeira anal e comprimento de suas bases equivalentes; nadadeira caudal com o lobo terminal bem desenvolvido, com a distância do entalhe subterminal até a extremidade posterior do lobo superior correspondendo aproximadamente à metade do comprimento do lobo superior. Coloração bronzeada a castanha dorsalmente; mais pálida na superfície ventral. $\mathrm{O}$ focinho é translúcido.

Tamanho: pode atingir até 1,7 $\mathrm{m}$ de CT; machos são considerados maduros a partir de 1,2 $\mathrm{m}$ de CT, e fêmeas, a partir de 1,3 m de CT; nasce com cerca de $30 \mathrm{~cm}$ de CT.

Distribuição, Hábitos e Biologia: distribui-se em todo o mundo pela zona pelágica e demersal da região costeira, e mesmo em áreas oceânicas adjacentes a ilhas, 
desde águas rasas até profundidades de $470 \mathrm{~m}$. Vivípara lecitotrófica, com período de gestação de aproximadamente 12 meses, parindo de seis a 52 filhotes por vez. Alimenta-se principalmente de cefalópodes e peixes ósseos. Tem grande importância comercial em diversas partes do mundo (Uruguai, Argentina, Europa, África do Sul, Austrália e Nova Zelândia), onde é capturada com frequência.

Observações: até o momento, um único registro de ocorrência dessa espécie no Estado do Rio de Janeiro é baseado em uma cabeça procedente de Barra de Guaratiba (depositado na coleção ictiológica da UERJ). Com base nesse registro, o Estado do Rio de Janeiro é o limite norte de distribuição dessa espécie no Oceano Atlântico Sul Ocidental.

\section{Gênero Mustelus}

Com crista dérmica interdorsal; nadadeiras dorsais com tamanhos similares; nadadeira anal visivelmente menor que a segunda nadadeira dorsal, comprimento de sua base cabendo aproximadamente 1,5 vezes no comprimento da base da segunda nadadeira dorsal; dentes pavimentosos, com bordas arredondadas, cúspides ausentes ou pouco perceptíveis. Encontrado desde águas temperadas a tropicais. São conhecidas 22 espécies no mundo, quatro delas ( $M$. canis, $M$. higmani, $M$. norrisi e $M$. schmitti) ocorrem no Rio de Janeiro.

\section{Chave para a Identificação das Espécies do Gênero Mustelus}

1a. Dentículos dérmicos abaixo da primeira nadadeira dorsal com três pontas (Fig. 145); superfície dorsal do corpo amarelada, evidente em animais frescos; diâmetro horizontal do olho menor que a distância internasal Mustelus higmani

1b. Dentículos dérmicos abaixo da primeira nadadeira dorsal com uma ou duas pontas (Fig. 146); superfície dorsal do corpo acinzentada em animais frescos; diâmetro horizontal do olho igual ou maior que a distância internasal

2

2a. Lobo inferior da nadadeira caudal arredondado e confluente à margem pósventral da nadadeira caudal (Fig. 147, seta); margem posterior das nadadeiras dorsais podendo apresentar faixa escura estreita, resultante da exposição da extremidade do esqueleto (Fig. 148, seta); ocasionalmente com pequenas pintas claras ordenadas longitudinalmente na região dorso-lateral do corpo (Fig. 149); comprimento pré-oral equivale a aproximadamente três vezes a distância internasal

Mustelus schimitti

2b. Lobo inferior da nadadeira caudal não arredondado e não confluente à margem pós-ventral da nadadeira caudal (Fig. 150, seta); margem posterior das nadadeiras 
dorsais sem faixa escura estreita (Fig. 151, seta); nunca com pequenas pintas claras ordenadas longitudinalmente na região dorso-lateral do corpo; comprimento préoral equivale a, no máximo, duas vezes a distância internasal

3a. Lobo inferior da nadadeira caudal falcado (Fig. 152, seta); ápice das nadadeiras peitorais pontiagudo (Fig. 153, seta); sulco labial superior maior que o sulco labial inferior (Fig. 154, setas); origem das nadadeiras pélvicas eqüidistante da origem das nadadeiras peitorais e da origem da nadadeira anal.

Mustelus norrisi 3b. Lobo inferior da nadadeira caudal não falcado (Fig. 155, seta); ápice das nadadeiras peitorais arredondado (Fig. 156, seta); sulco labial superior igual ou menor que o sulco labial inferior (Fig. 157, setas); origem das nadadeiras pélvicas mais próxima da origem da nadadeira anal do que da origem da nadadeira peitoral.

Mustelus canis

Mustelus higmani Springer \& Lowe, 1963 (Fig. 158)

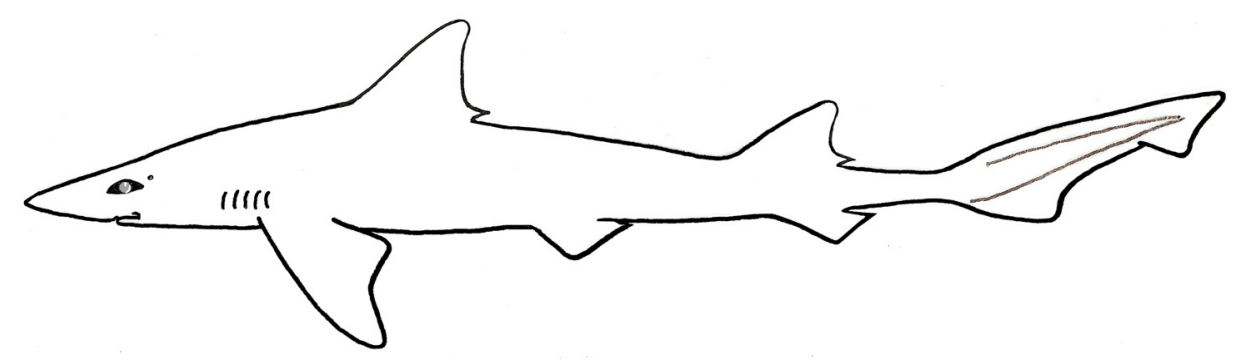

Nomes populares: sebastião, canejo, cação-diabo, boca-de-velha.

Caracteres distintivos: dentículos dérmicos abaixo da primeira nadadeira dorsal com três pontas; diâmetro horizontal do olho menor que a distância internasal, cabendo 1,5 vezes nesta distância; nadadeiras peitorais com ápice levemente pontiagudo; nadadeiras pélvicas relativamente pequenas, comprimento de suas margens anteriores está contida cerca de 2,5 vezes o comprimento da margem anterior das nadadeiras peitorais. Coloração amarelada em todo o corpo, observada principalmente em animais frescos.

Tamanho: CT máximo de $64 \mathrm{~cm}$; machos maduros com $43 \mathrm{~cm}$, alcançando até 49 cm de CT, fêmeas maduras com cerca de $48 \mathrm{~cm}$ de CT, alcançando até $58 \mathrm{~cm}$; CT ao nascer entre 21 e $24 \mathrm{~cm}$.

Distribuição, Hábitos e Biologia: distribuição restrita à costa atlântica da América do Sul (da Venezuela ao Sudeste do Brasil). Habita a plataforma continental, em águas tropicais, até cerca de $100 \mathrm{~m}$ de profundidade. Vivípara placentotrófica, parindo de um a sete filhotes por vez. Alimentam-se principalmente de crustáceos, complementando sua dieta com celenterados, moluscos (lulas e polvos) e pequenos peixes ósseos.

Observações: recentemente foi realizado um estudo sobre sua biologia reprodutiva no litoral norte do Estado do Rio de Janeiro, a partir do qual se registrou o maior CT de machos e fêmeas, com 58 cm e 61,3 cm, respectivamente; a maturação sexual nos 
machos encontrada foi entre 45 e $50 \mathrm{~cm}$ de CT, e nas fêmeas foi entre 40 e $50 \mathrm{~cm}$ de CT. Ainda nesse trabalho foi sugerido que a área de estudo abrangida (Enseada de Manguinhos - RJ) seja utilizada como berçário de M. higmani.

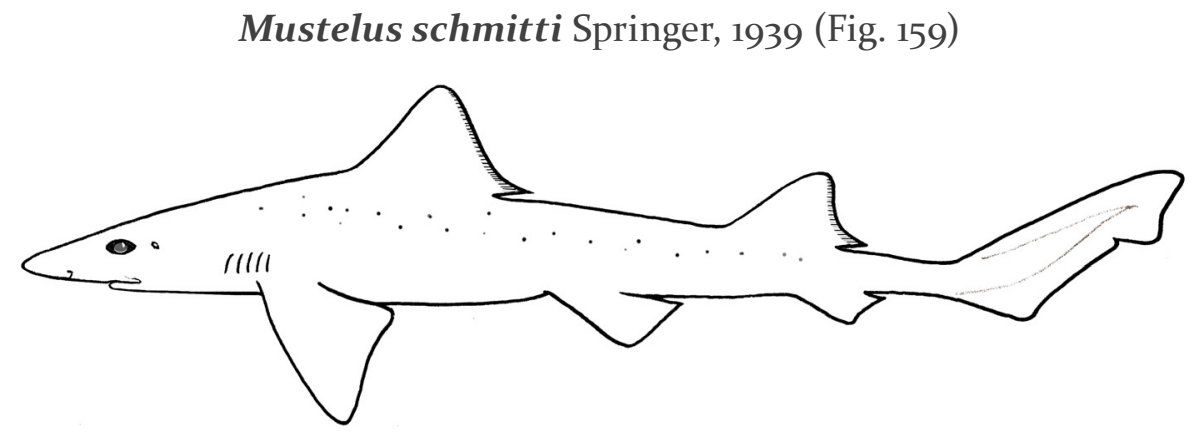

Nomes populares: sebastião, canejo.

Caracteres distintivos: lobo inferior da nadadeira caudal arredondado e confluente com a margem pós-ventral da nadadeira caudal; margem posterior das nadadeiras dorsais com faixa escura estreita, resultante da exposição da extremidade do esqueleto; comprimento pré-oral equivalendo aproximadamente três vezes a distância internasal; diâmetro horizontal dos olhos equivalente à distância internasal; nadadeiras peitorais com ápice arredondado; nadadeiras pélvicas relativamente grandes, comprimento de suas margens anteriores correspondendo a mais da metade do comprimento das margens anteriores das nadadeiras peitorais. Coloração cinza em todo o corpo; alguns exemplares com pequenas pintas claras ordenadas longitudinalmente na região dorso-lateral do corpo; faixas escuras estreitas na margem posterior da primeira nadadeira dorsal em alguns exemplares.

Tamanho: CT máximo estimado de $74 \mathrm{~cm}$; machos maduros a partir de $48 \mathrm{~cm}$ e fêmeas entre 55 e 60 cm de CT; os filhotes nascem com cerca de 26 cm de CT.

Distribuição, Hábitos e Biologia: registrada apenas do Sudeste do Brasil até a Argentina. Encontrada na plataforma continental, associada ao substrato marinho, entre as profundidades de 60 e $195 \mathrm{~m}$. O desenvolvimento embrionário se dá por viviparidade sem placenta, com dois a sete filhotes por ninhada. Presume-se que sua dieta alimentar seja constituída de crustáceos e pequenos peixes ósseos.

Observação: aparentemente tem seu limite norte de distribuição na costa do Estado do Rio de Janeiro.

Mustelus norrisi Springer, 1939 (Fig. 160)

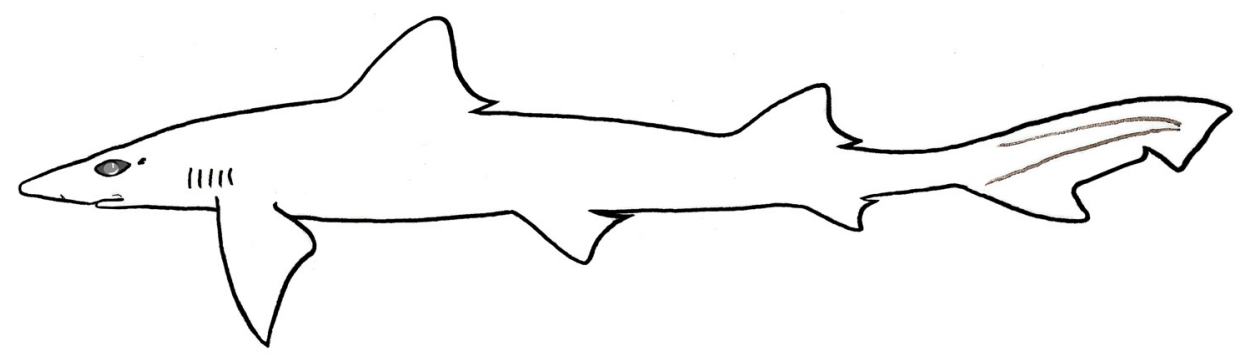


Nomes populares: sebastião, canejo.

Caracteres distintivos: lobo inferior da nadadeira caudal falcado; ápice das nadadeiras peitorais pontiagudo; sulco labial superior maior que o inferior; origem das nadadeiras pélvicas equidistantes entre a origem das nadadeiras peitorais e origem da nadadeira anal; diâmetro horizontal dos olhos equivalente à distância internasal; nadadeiras pélvicas relativamente grandes (proporcionalmente maiores que as de $M$. higmani, porém menores que as de $M$. canis), comprimento de suas margens anteriores correspondendo a mais de 1,5 vezes o comprimento da margem anterior das nadadeiras peitorais. Coloração cinza em todo o corpo, com ventre mais claro.

Tamanho: CT máximo estimado de aproximadamente um metro; machos amadurecem com cerca de $58 \mathrm{~cm}$, e fêmeas, com cerca de $65 \mathrm{~cm}$; ao nascerem os indivíduos medem aproximadamente $30 \mathrm{~cm}$ de CT.

Distribuição, Hábitos e Biologia: distribuição restrita à costa atlântica da América do Sul. Ocorre na Flórida e norte do Golfo do México, até a Venezuela. No Brasil, é encontrada no Nordeste, Sudeste e Sul. Vive sobre a plataforma continental, em águas tropicais até pelo menos $80 \mathrm{~m}$ de profundidade. $\mathrm{O}$ desenvolvimento embrionário se faz por viviparidade placentotrófica, parindo de sete a 17 filhotes por vez. Alimentação constituída de crustáceos (caranguejos e camarões) e pequenos peixes ósseos bentônicos.

Observações: embora a literatura inclua sua distribuição no Sul do Brasil e exclua no Nordeste, aparentemente o que ocorre é exatamente o contrário, pois na costa Sul há muito tempo existem amostragens de tubarões do gênero Mustelus, sem que sua captura fosse notificada. Há registros na costa Nordeste, e o limite sul de sua ocorrência na costa brasileira refere-se a dois exemplares capturados na costa do Rio de Janeiro, medindo $45 \mathrm{~cm}$ de CT (os únicos procedentes do Sudeste até o momento). Seus registros são menos frequentes que os de que $M$. canis e $M$. schmitti.

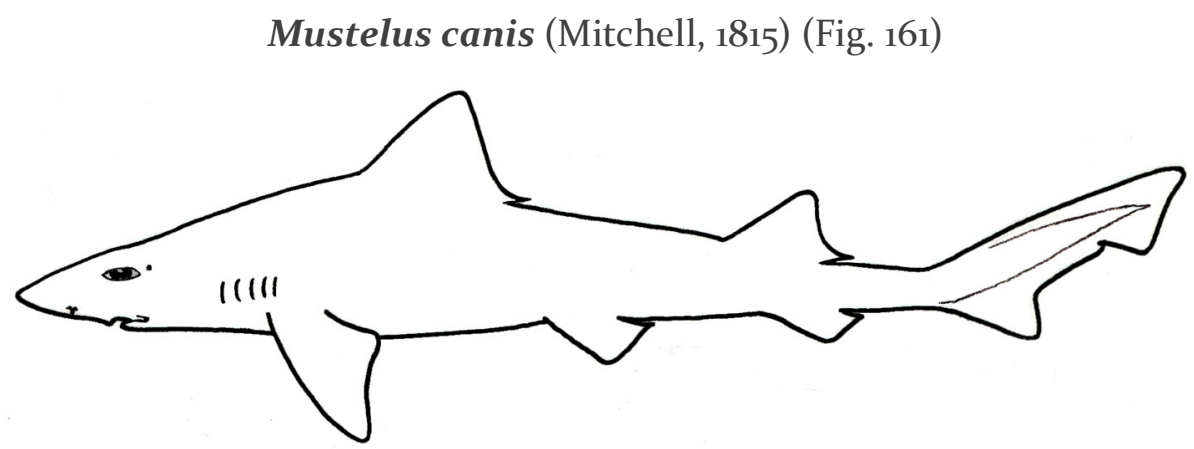

Nomes populares: canejo, sebastião.

Caracteres distintivos: lobo inferior da nadadeira caudal não falcado; ápice das nadadeiras peitorais arredondado; sulco labial superior igual ou menor que o inferior; origem das nadadeiras pélvicas mais próximas da origem da nadadeira anal do que da origem da nadadeira peitoral; diâmetro horizontal do olho equivalente à distância 
internasal; nadadeiras pélvicas relativamente grandes, comprimento de sua margem anterior corresponde à metade do comprimento da margem anterior das nadadeiras peitorais. Coloração castanha acinzentada no dorso e mais clara na região ventral.

Tamanho: CT máximo de 1,5 m; machos amadurecem a partir de $80 \mathrm{~cm}$, e fêmeas a partir de $90 \mathrm{~cm}$ de CT; nasce com cerca de $32 \mathrm{~cm}$ de CT.

Distribuição, Hábitos e Biologia: espécie restrita ao Oceano Atlântico Ocidental, ocorrendo até o norte da Argentina. No Brasil, é encontrada nas regiões Nordeste, Sudeste e Sul. Vive sobre a plataforma continental, desde águas rasas, a pouco mais de $100 \mathrm{~m}$, até cerca de $800 \mathrm{~m}$, embora a maioria das capturas não seja abaixo dos $400 \mathrm{~m}$. Desenvolvimento embrionário se faz por viviparidade placentotrófica, com período de gestação de aproximadamente dez meses, parindo de três a 15 filhotes por vez. Alimenta-se principalmente de crustáceos e peixes ósseos demersais.

\section{Família CARCHARHINIDAE}

Olhos com membranas nictitantes desenvolvidas e móveis; primeira nadadeira dorsal situada anteriormente às nadadeiras pélvicas; presença de sulcos pré-caudais, superior e inferior; habitam os mais diversos ambientes, desde a costa à região oceânica, em regiões estuarinas (podendo, inclusive penetrar em água doce, como Carcharhinus leucas), dentro de baías e regiões insulares, desde águas rasas até grandes profundidades. Inclui numerosas espécies de extrema importância trófica nos ecossistemas marinhos costeiros de águas tropicais e subtropicais, bem como a maioria das espécies potencialmente perigosas ao homem. Do ponto de vista econômico, também representam a maioria dos produtos da pesca de elasmobrânquios, em muitas regiões. A família Carcharhinidae é bem diversificada e numerosa, com 12 gêneros e cerca de 50 espécies no mundo. Na costa do Estado do Rio de Janeiro, está representada por cinco gêneros: Galeocerdo, Prionace, Negaprion, Rhizoprionodon e Carcharhinus.

\section{Chave para Identificação dos Gêneros da Família Carcharhinidae}

1a. Sulco labial superior atingindo a frente dos olhos (Fig. 162, setas); espiráculos presentes; cristas dérmicas laterais no pedúnculo caudal presentes (Fig. 163 seta)

Galeocerdo

1b. Sulco labial nunca atingindo a frente dos olhos (Fig. 164, setas); espiráculos ausentes; cristas dérmicas laterais no pedúnculo caudal ausentes (Fig. 165, seta), exceto em alguns exemplares de Prionace glauca. .2

2a. Primeira nadadeira dorsal posicionada posteriormente, com vertical que passa pelo meio de sua base situada mais próxima da origem das nadadeiras pélvicas do 
que da inserção das nadadeiras peitorais (Fig. 166); coloração azul intensa quando o animal está vivo ou recém morto

Prionace

2b. Primeira nadadeira dorsal posicionada anteriormente, com vertical que passa pelo meio de sua base situada mais próxima da inserção das nadadeiras peitorais do que da origem das nadadeiras pélvicas (Fig. 167); sem coloração azul intensa

3a. Segunda nadadeira dorsal quase do tamanho da primeira, com sua base sendo pelo menos 3/4 da base da primeira nadadeira dorsal (Fig. 168)

Negaprion

3b. Segunda nadadeira dorsal visivelmente menor que a primeira, com sua base sendo menos de 3/4 da base da primeira nadadeira dorsal (Fig. 169).

4a. Sulco labial superior desenvolvido, visível mesmo quando a boca está fechada (Fig. 170, seta); com cristas pré-anais (Fig. 171, seta); origem da segunda nadadeira dorsal sobre o meio da base da nadadeira anal (Fig. 172) (exceto em Carcharhinus porosus, que também apresenta essa característica).

Rhizoprionodon 4b. Sulco labial superior pouco desenvolvido, pouco visível, mesmo quando a boca está aberta (Fig. 173, seta); sem cristas pré-anais (Fig. 174, seta); origem da segunda nadadeira dorsal sobre origem da nadadeira anal (Fig. 175) (exceto em Carcharhinus porosus, que não apresenta essa característica).

.Carcharhinus

\section{Gênero Galeocerdo}

Sulco labial superior muito desenvolvido, estendendo-se até a frente dos olhos; espiráculos presentes; cristas dérmicas laterais visíveis no pedúnculo caudal. Gênero monoespecífico (Galeocerdo cuvier), de distribuição mundial.

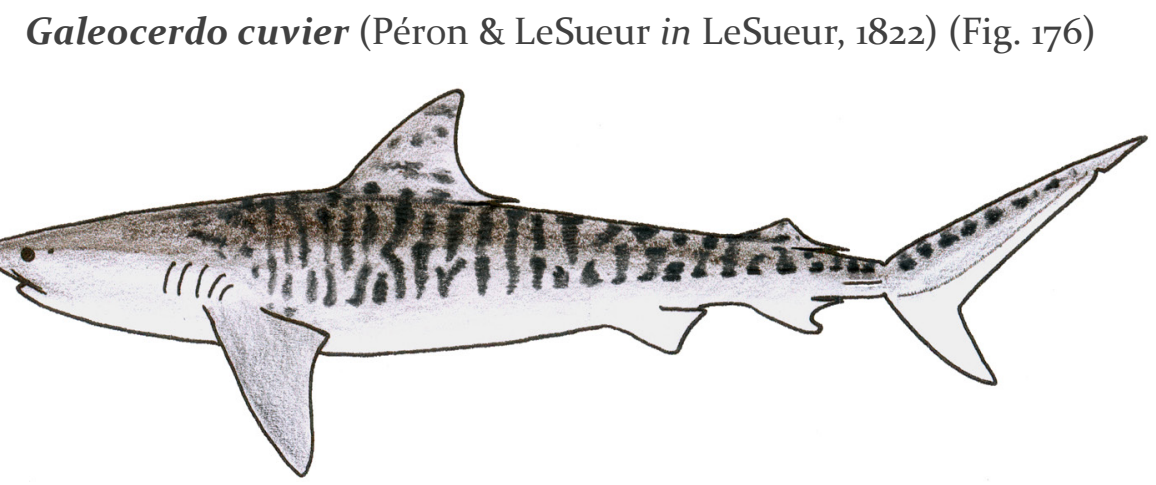

Nomes populares: tintureira, tubarão-tigre, jaguara.

Caracteres distintivos: focinho curto e arredondado, com comprimento pré-oral equivalente à distância internasal, cabendo mais ou menos uma vez nesta distância; dentes iguais em ambas arcadas, fortemente serrilhados, de cúspide curvada, com um profundo entalhe na margem comissural; origem da primeira nadadeira dorsal sobre ou posterior à inserção das nadadeiras peitorais; origem da segunda nadadeira 
dorsal pouco anterior à origem da nadadeira anal; nadadeira anal equivalente em tamanho à segunda nadadeira dorsal, mas com sua margem posterior falcada; pedúnculo caudal com sulcos pré-caudais superior e inferior, e com cristas dérmicas laterais. Coloração dorsal cinza, com pintas e estrias escuras evidentes nos jovens, que tendem a formarem listras nos adultos (animais muito grandes podem perder essas listras); ventre claro.

Tamanho: CT máximo por volta dos seis metros, com um registro de $7,4 \mathrm{~m}$ e outro de nove metros de CT (não confirmados); a maturação nos machos ocorre entre 2,2 e 2,9 m de CT e, nas fêmeas, entre 2,5 e 3,5 m de CT, aproximadamente; nasce com cerca de 50 a $70 \mathrm{~cm}$ de $\mathrm{CT}$.

Distribuição, Hábitos e Biologia: espécie encontrada em todos os oceanos, preferencialmente na região costeira, de águas tropicais até temperadas. Ocasionalmente também é avistada em áreas oceânicas abertas ou ao entorno de ilhas, normalmente a cerca $350 \mathrm{~m}$ de profundidade ou mais. Ocorre em toda a costa brasileira, sendo mais frequente nas regiões Norte e Nordeste. Único Carcharhinidae não placentário, com desenvolvimento embrionário por viviparidade lecitotrófica. A mãe pode parir de dez a 82 filhotes por vez, com período de gestação estimado em mais de um ano. Dieta alimentar bastante diversificada e constituída de grande variedade de organismos, incluindo outros elasmobrânquios, tartarugas e mamíferos marinhos.

Observações: juntamente com o cabeça-chata, Carcharhinus leucas, e o tubarãobranco, Carcharodon carcharias, essa é uma das espécies mais perigosas para o homem, com mais de 145 casos de ataques comprovados no mundo (28 mortes), a maioria nas regiões tropicais. Considerando apenas os casos não provocados, essa espécie é estatisticamente a mais letal, com 32,6\% de mortes (versus 30,1\% por Carcharhinus leucas e 27,1\% por Carcharodon carcharias). Dois acidentes atribuídos a essa espécie ocorreram no Rio de Janeiro, há muitos anos. No primeiro, um banhista foi morto em Copacabana em junho de 1947 (não foi descartada a possibilidade do ataque ter sido causado pelo tubarão-branco, Carcharodon carcharias). Em 1956, do estômago de um grande exemplar capturado em Angra dos Reis, foi retirada a cabeça de uma mulher, sem que as causas reais de sua morte fossem de fato apuradas. Em tempos atuais, a espécie é capturada esporadicamente ao longo de toda a costa, especialmente no norte do Estado. No município do Rio de Janeiro, há registros de exemplares capturados no Pontal da Barra (Recreio dos Bandeirantes) e Arquipélago das Cagarras - RJ, e vendidos no Posto seis, que é uma tradicional colônia de pescadores em Copacabana.

\section{Gênero Prionace}

Caracterizado pela primeira nadadeira dorsal posicionada mais posteriormente, com o meio de sua base situado mais próximo da origem das nadadeiras pélvicas que 
da inserção das nadadeiras peitorais, e pela coloração azul intensa em animais ainda frescos. É um gênero monoespecífico (Prionace glauca), de distribuição mundial.

Prionace glauca (Linnaeus, 1758) (Fig. 177)

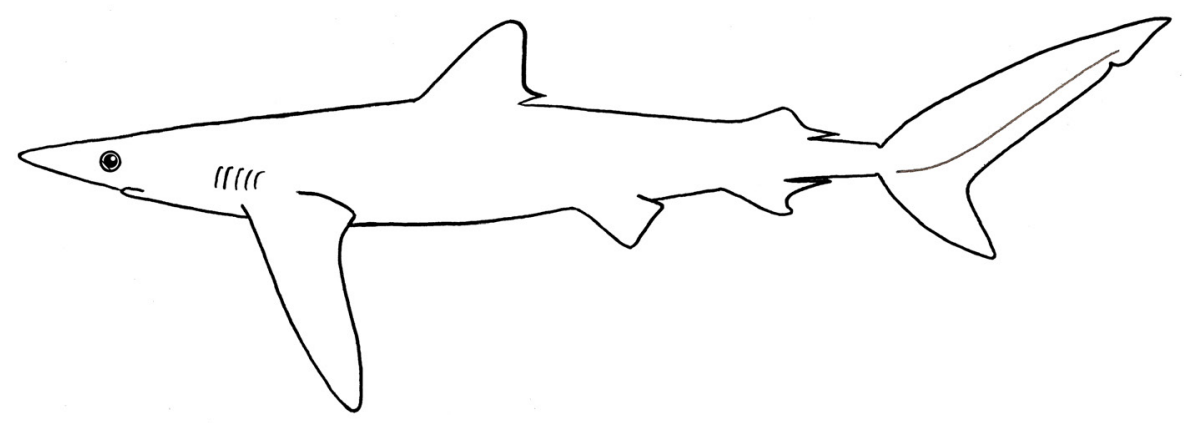

Nomes populares: tubarão-azul, cação-azul, focinhudo, mole-mole.

Caracteres distintivos: focinho longo e afilado, com comprimento pré-oral equivalendo aproximadamente ao dobro da distância internasal; dentes diferentes nas arcadas superior e inferior, os superiores largos, serrilhados e oblíquos, os inferiores afilados e levemente serrilhados; nadadeiras peitorais longas, com comprimento semelhante ao comprimento da cabeça. Coloração azul intensa no dorso; ventre branco.

Tamanho: pode chegar até cerca de 3,8 m de CT; machos maduros entre 1,8 e 2,8 m, e fêmeas, entre 1,9 e 2,2 m de CT; nasce entre 35 e 44 cm de CT.

Distribuição, Hábitos e Biologia: distribuição principalmente oceânica em águas tropicais, subtropicais e temperadas de todos os oceanos. Encontrada normalmente na zona pelágica, atingindo até $150 \mathrm{~m}$ de profundidade. Considerada a espécie de tubarão de grande porte mais abundante nesses ambientes. $\mathrm{O}$ desenvolvimento dos embriões se dá por viviparidade placentária, parindo de quatro a 135 embriões. Alimenta-se de moluscos cefalópodes (lulas), outros invertebrados, pequenos peixes ósseos e, eventualmente, aves marinhas e carcaças de mamíferos marinhos.

Observações: considerado também potencialmente perigoso, responsável por ataques a náufragos em regiões oceânicas. Essa espécie é capturada com frequência nos espinhéis de atum e considerada vulnerável para o município do Rio de Janeiro, de acordo com a lista de fauna ameaçada em extinção (Buckup et al., 200o).

\section{Gênero Negaprion}

As duas nadadeiras dorsais com tamanho aproximadamente igual caracterizam o gênero. Há apenas duas espécies no mundo, e uma delas ocorre no Brasil (Negaprion brevirostris), com registros para o Rio de Janeiro e São Paulo. 


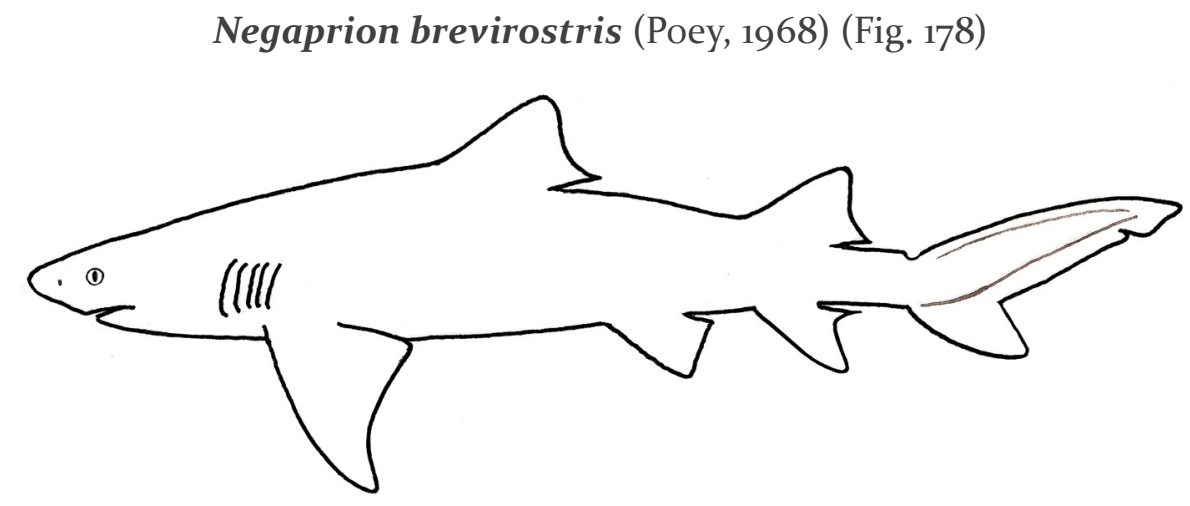

Nomes populares: cação-limão; cabeça-redonda.

Caracteres distintivos: focinho curto e arredondado, com comprimento pré-oral equivalente à distância internasal, cabendo mais ou menos uma vez nessa distância; sulco labial superior rudimentar e inferior ausente; segunda nadadeira dorsal quase tão grande quanto a primeira, com o comprimento de sua base pelo menos 3/4 da base da primeira nadadeira dorsal; origem da nadadeira anal posterior à origem da segunda nadadeira dorsal, com sua margem posterior falcada. Coloração cinza amarelada dorsalmente; mais clara ventralmente.

Tamanho: CT cerca de 3,4 m; machos e fêmeas maduros com aproximadamente 2,2 e 2,4 $\mathrm{m}$ de CT, respectivamente; as crias nascem com cerca de 50 a $60 \mathrm{~cm}$ de CT.

Distribuição, Hábitos e Biologia: distribuição costeira no Atlântico Ocidental e Pacífico Oriental. Demersal ou pelágica, vive mais associada ao substrato, principalmente em águas tropicais, desde regiões rasas (frequentemente em áreas de manguezal) até pelo menos $90 \mathrm{~m}$ de profundidade. Espécie vivípara placentária, produz de quatro a 17 filhotes por vez, após 10-12 meses de gestação. Alimentação constituída por moluscos, crustáceos e peixes ósseos.

Observações: o cação-limão é considerado raro na região Sudeste do Brasil (mais frequente no Norte/Nordeste, sobretudo nas ilhas oceânicas), e também potencialmente perigoso a banhistas por seu grande porte e hábitos costeiros. O registro que se tem notícia para o Rio de Janeiro é uma fêmea de $578 \mathrm{~mm}$ de comprimento, pescado na praia do Una, próximo ao Rio Una, Município de Casimiro de Abreu, no dia 30 de Janeiro de 1982 (material depositado na coleção ictiológica da UERJ).

\section{Gênero Rhizoprionodon}

Seus representantes apresentam como características principais: sulco labial superior bem desenvolvido, evidenciado mesmo com a boca fechada; presença de cristas pré-anais; origem da segunda nadadeira dorsal sobre o meio da base da nadadeira anal (o que também ocorre em Carcharhinus porosus). A maioria dos tubarões desse gênero tem hábitos costeiros em águas relativamente rasas. São os 
mais abundantes dos pequenos tubarões costeiros em muitas partes do mundo. Do total das sete espécies conhecidas, apenas duas delas (Rhizoprionodon lalandii e $R$. porosus) são registradas no Estado do Rio de Janeiro.

\section{Chave para Identificação das Espécies do Gênero Rhizoprionodon}

1a. Extremidade do focinho arredondada; focinho com comprimento pré-oral menor que a largura da boca (Fig. 179, setas); nadadeiras peitorais, quando comprimidas junto às laterais do corpo, atingem o nível do segundo ou terceiro terço da base da primeira nadadeira dorsal (Fig. 18o, seta); segunda nadadeira dorsal com ápice enegrecido (Fig. 180, seta); dorso cinzento, às vezes com pontuações brancas

Rhizoprionodon porosus

1b. Extremidade do focinho pontiaguda; focinho com comprimento pré-oral maior que a largura da boca (Fig. 181, setas); nadadeiras peitorais, quando comprimidas junto as laterais do corpo, atingem o nível do primeiro ou segundo terço da base da primeira nadadeira dorsal (Fig. 182 seta); segunda nadadeira dorsal sem ápice enegrecido (182, seta); dorso bronzeado, com tons esverdeados e sem qualquer pontuação.

Rhizoprionodon lalandii

Rhizoprionodon porosus (Poey, 1861) (Fig. 183)

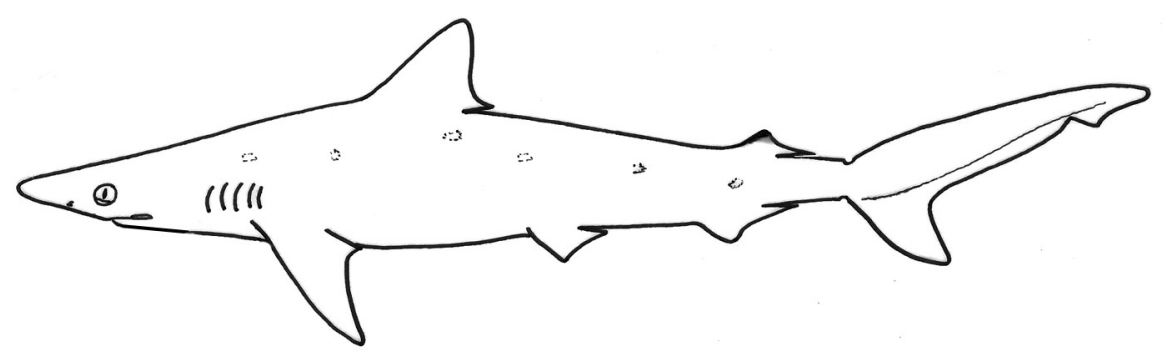

Nomes populares: cação-frango, rabo-seco, pintadinho.

Caracteres distintivos: focinho curto e arredondado, com comprimento préoral menor que a largura da boca; dentes similares em ambas as arcadas, oblíquos, com forte entalhe no canto da boca, por vezes finamente serrilhados (adultos); nadadeiras peitorais, quando comprimidas junto às laterais do corpo, alcançam o nível do segundo ou terceiro terço da base da primeira nadadeira dorsal (Fig. 180). Coloração acinzentada no dorso, com pontos brancos em alguns exemplares adultos; extremidade da segunda nadadeira dorsal enegrecida; ventre claro.

Tamanho: CT máximo de pelo menos 1,2 m; maturação sexual ocorre nos machos entre 76 e 80 cm de CT, e nas fêmeas, entre 81 e 85 cm de CT; nasce entre 31 e 39 cm de CT.

Distribuição, Hábitos e Biologia: tem distribuição restrita à costa atlântica das Américas Central e do Sul, desde a região caribenha até, pelo menos, o Sul do Brasil. 
Pelágica e demersal, vive sobre a plataforma continental, desde águas rasas até cerca de $90 \mathrm{~m}$ de profundidade, com raros registros abaixo de $100 \mathrm{~m}$. A gestação se dá por viviparidade placentária, produzindo de dois a cinco filhotes por parto. A alimentação é constituída por lulas, crustáceos (camarões, por exemplo) e peixes ósseos.

Observações: o ciclo reprodutivo dessa espécie foi estudado na região de Barra de Guaratiba, sul do Estado do Rio de Janeiro. Durante a primavera, há predomínio de capturas de fêmeas recém-fecundadas (são mais abundantes que os machos), e o parto se faz durante o inverno. O período de gestação foi estimado em 12 meses. Considerada vulnerável para o município do Rio de Janeiro, de acordo com a listagem de fauna ameaçada em extinção (Buckup et al., 200o).

Rhizoprionodon lalandii (Müller \& Henle 1839) (Fig. 184)

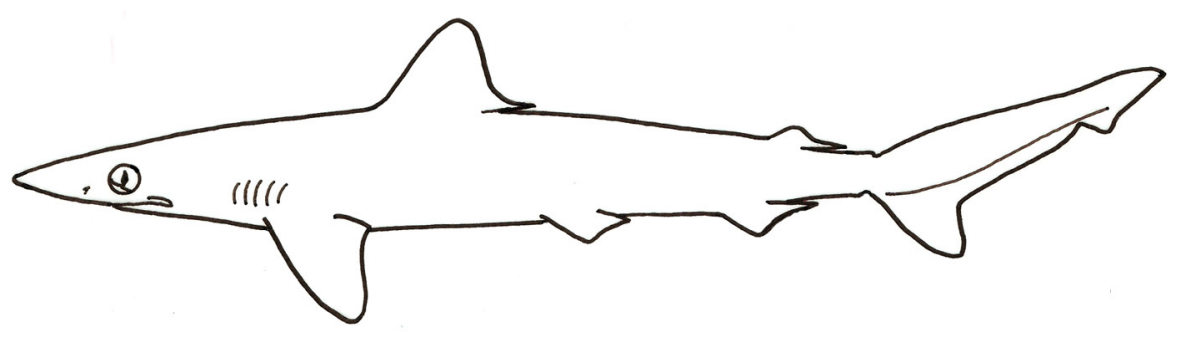

Nome popular: cação-frango.

Caracteres distintivos: focinho longo e afilado, com comprimento pré-oral correspondendo a aproximadamente 1,5 vezes à largura da boca; dentes das arcadas superior e inferior iguais, oblíquos, com forte entalhe no lado comissural e sem serrilhas; nadadeiras peitorais, quando comprimidas junto às laterais do corpo, alcançam o nível do primeiro ou segundo terço da base da primeira nadadeira dorsal (Fig. 182).

Tamanho: CT máximo de $75 \mathrm{~cm}$; a maturação sexual ocorre entre 55 e $60 \mathrm{~cm}$ de CT nos machos e entre 61 e $65 \mathrm{~cm}$ de CT nas fêmeas; nasce com cerca de $33 \mathrm{~cm}$ de CT. Coloração dorsal bronzeada, com tons esverdeados; usualmente a extremidade do prolongamento posterior das nadadeiras dorsais são mais claras, despigmentadas; ventre mais claro.

Distribuição, Hábitos e Biologia: distribuição restrita à costa atlântica das Américas Central e do Sul. Vive sobre a plataforma continental associada ao substrato marinho, podendo chegar a $70 \mathrm{~m}$ de profundidade. Machos sexualmente maduros apresentam acentuado dimorfismo sexual dentário, no qual os dentes são afilados e cilíndricos próximos da sínfise da boca (junção central das arcadas dentárias). Alimentação baseada principalmente em moluscos cefalópodes (lulas), crustáceos (camarões) e peixes ósseos.

Observações: a reprodução dessa espécie foi estudada no Rio de Janeiro e os dados resultantes indicam que a maturação ocorre entre 50 e $60 \mathrm{~cm}$ de CT. Após isso, os animais entram em reprodução contínua, com vitelogênese e gravidez. Fêmeas grávidas aparecem no outono e carregam de dois a cinco embriões em adiantado 
estágio de desenvolvimento, e no inverno ocorre o parto. O período de gestação foi estimado em 12 meses. Esses dados são similares na costa do Estado de São Paulo. Considerada vulnerável para o município do Rio de Janeiro de acordo com a lista de fauna ameaçada em extinção (Buckup et al., 200o).

\section{Gênero Carcharhinus}

Caracteriza-se por apresentar sulco labial superior pouco desenvolvido, não visível quando a boca está fechada; sem cristas pré-anais; origem da segunda nadadeira dorsal sobre a origem da nadadeira anal, exceto em Carcharhinus porosus. Apresenta ampla distribuição mundial, com registros em todos os oceanos, em regiões temperadas e tropicais, em águas costeiras e oceânicas, como visto anteriormente na diagnose da família. Conhecidas 30 espécies no mundo, dez delas ocorrem na costa do Estado do Rio de Janeiro. Compreende um dos mais abundantes grupos de tubarões em número de espécies. Muitas de suas espécies são de difícil identificação.

\section{Chave para Identificação das Espécies do Gênero Carcharhinus}

1a. Nadadeiras peitorais e primeira nadadeira dorsal com ápice notavelmente arredondado; ápice da margem livre da segunda nadadeira dorsal alcançando o sulco pré-caudal superior; adultos com mancha branca nas extremidades das nadadeiras peitorais e na primeira nadadeira dorsal (Fig. 185, setas) Carcharhinus longimanus

1b. Nadadeiras peitorais e primeira nadadeira dorsal com ápice pontiagudo, pouco arredondado; ápice da margem livre da segunda nadadeira dorsal não alcança o sulco pré-caudal superior; adultos sem mancha branca nas extremidades das nadadeiras peitorais e na primeira nadadeira dorsal (Fig. 186, setas).

2

2a. Origem da segunda nadadeira dorsal situada sobre, ou posteriormente ao ponto médio da base da nadadeira anal (Fig. 187).....

Carcharhinus porosus

2b. Origem da segunda nadadeira dorsal situada anteriormente à origem da nadadeira anal (Fig. 188)

\section{.3}

3a. Nadadeiras peitorais com ápice negro em qualquer estágio de desenvolvimento, às vezes não evidente em neonatos de C. brevipinna (Fig. 189).....

3b. Nadadeiras peitorais sem ápice negro em qualquer estágio de desenvolvimento (Fig. 190).....

4a. Primeira fenda branquial até 2,5 vezes maior que o diâmetro horizontal do olho; diâmetro horizontal do olho cabe cinco vezes na distância pré-oral; origem da primeira nadadeira dorsal posicionada sobre uma linha imaginária que passa pela axila da nadadeira peitoral (Fig. 191) 
4b. Primeira fenda branquial cabendo mais que quatro vezes no diâmetro horizontal do olho; diâmetro horizontal do olho cabe de sete a oito vezes na distância préoral; origem da primeira nadadeira dorsal sobre uma linha imaginária que passa pela margem livre (posterior) da nadadeira peitoral (Fig. 192).....Carcharhinus brevipinna 5a. Ponta do focinho com mancha negra (Fig. 193, seta)........Carcharhinus acronotus 5b. Ponta do focinho sem mancha negra (Fig. 194, seta) .................................................6 6a. Dentes superiores próximos da sínfise da boca largos, com formato triangular, sem cúspide destacada da base (Fig. 195, seta).

6b. Dentes superiores próximos da sínfise, estreitos e com cúspide destacada da base (Fig. 196, seta)......

7a. Origem da primeira nadadeira dorsal situada depois da metade da margem interna da nadadeira peitoral, algumas vezes depois do ápice da margem interna dessa nadadeira (Fig. 197).....

Carcharhinus obscurus

7b. Origem da primeira nadadeira dorsal situada antes da margem interna da nadadeira peitoral, algumas vezes antes da axila dessa nadadeira (Fig. 198)................ 8

8a. Com crista dérmica interdorsal (Fig. 199, seta); origem da primeira nadadeira dorsal sobre ou anterior à inserção da base da nadadeira peitoral (Fig. 198); primeira nadadeira dorsal muito alta, com altura correspondendo à metade da distância entre a ponta do focinho e a origem da primeira nadadeira dorsal, caráter nem sempre evidente em exemplares neonatos (Fig. 200, A); altura da primeira nadadeira dorsal maior ou igual à distância entre a margem anterior do olho até a terceira fenda branquial (Fig. 200, B)...

Carcharhinus plumbeus

8b. Sem crista dérmica interdorsal (Fig. 201, seta); origem da primeira nadadeira dorsal posterior à inserção da base da nadadeira peitoral (Fig. 205); primeira nadadeira dorsal baixa, com altura menor que a metade da distância entre a ponta do focinho e a origem da primeira nadadeira dorsal; caráter evidente em exemplares de qualquer tamanho (Fig. 202, A); altura da primeira nadadeira dorsal menor que a distância entre margem anterior do olho até a terceira fenda branquial (Fig. 202, B).

Carcharhinus leucas

9a. Focinho longo e estreito; distância internasal cabendo cerca de duas vezes no comprimento pré-oral (Fig. 203, setas) Carcharhinus signatus

9b. Focinho curto e largo; distância internasal cabendo cerca de uma a 1,5 vezes no comprimento pré-oral (Fig. 204, setas). .10 10a. Origem da primeira nadadeira dorsal posterior à margem livre da nadadeira peitoral (Fig. 205); com cristainterdorsal. Carcharhinus falciformis 1ob. Origem da primeira nadadeira dorsal sobre ou anterior à margem livre da nadadeira peitoral (Fig. 206); . .11 11a. Dentes superiores com bordas grosseiramente serrilhadas (Fig. 207); arcada dentária com 15 a 16 dentes de cada lado da sínfise superior..Carcharhinus brachyurus 11b. Dentes superiores com bordas finamente serrilhadas (Fig. 208); nunca mais de 13 dentes de cada lado da sínfise superior..

Carcharhinus perezi 


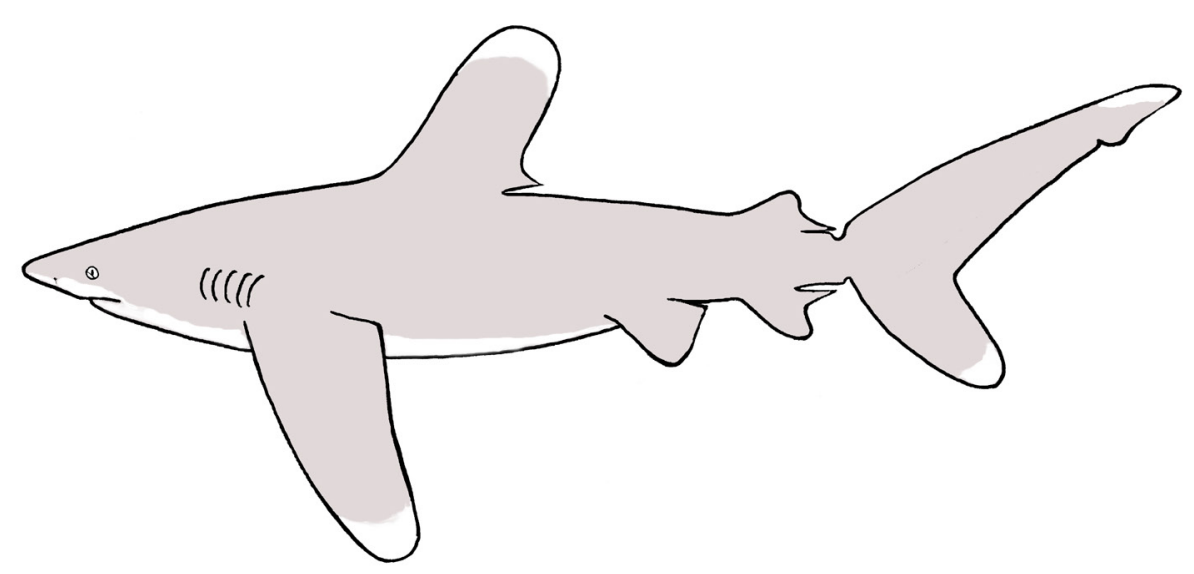

Nomes populares: galha-branca, cação-baía, estrangeiro.

Caracteres distintivos: focinho relativamente curto e arredondado, com comprimento pré-oral correspondendo de uma a 1,1 vezes a distância internasal; ápices das nadadeiras peitorais e primeira nadadeira dorsal notavelmente arredondados; origem da primeira nadadeira dorsal pouco posterior ao ápice das margens internas das nadadeiras peitorais; crista dérmica interdorsal presente. Coloração castanha com tons acinzentados dorsalmente; ventre branco; presença de manchas brancas nas nadadeiras peitorais, primeira nadadeira dorsal, nadadeiras pélvicas e ápice da nadadeira caudal (nos adultos). Indivíduos juvenis com manchas negras nas nadadeiras pélvicas, segunda nadadeira dorsal, nadadeira anal, lobo inferior da nadadeira caudal. Os espécimes imaturos possuem também selas negras na inserção da segunda nadadeira dorsal e na origem do lobo superior da nadadeira caudal (por vezes entre as nadadeiras dorsais também). Esse padrão desaparece com o crescimento.

Tamanho: CT máximo de aproximadamente 3,9 m; machos amadurecem entre 1,75 e 1,98 m de CT e fêmeas, entre 1,8 e $2 \mathrm{~m}$ de CT. Nascem medindo entre 60 e $65 \mathrm{~cm}$ de CT.

Distribuição, Hábitos e Biologia: distribuição cosmopolita. No Brasil, registrada ao longo de toda costa (mais abundante no Nordeste). Vive na zona pelágica em regiões oceânicas, em águas tropicais e temperadas quentes (ocasionalmente chegam à costa). Encontrada até cerca de $150 \mathrm{~m}$ de profundidade. Vivípara placentária, produz de um a 15 filhotes por parto. Alimentação constituída de moluscos cefalópodes, crustáceos, diferentes espécies de peixes ósseos oceânicos, tartarugas e aves marinhas.

Observações: acredita-se que as manchas brancas de suas nadadeiras aparentam, à longa distância, pequenos grupos de peixes, de maneira que esse animal pode se aproximar dissimuladamente de suas presas, até deflagrar o ataque final. Isso explicaria como esses tubarões, sabidamente nadadores lentos, apresentam peixes velozes em seus estômagos. Constitui uma das espécies oceânicas mais abundantes e também potencialmente perigosas, com vários registros de ataques a náufragos. 


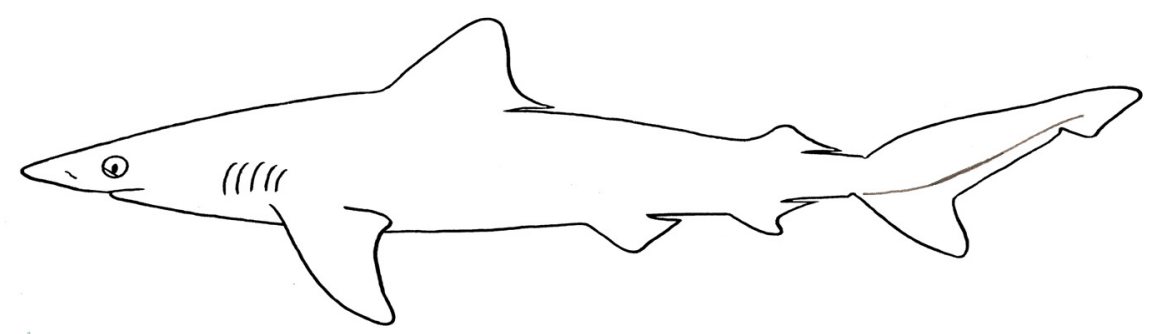

Nomes populares: cação-junteiro, azeiteiro, sucuri-branco.

Caracteres distintivos: origem da segunda nadadeira dorsal sobre ou posterior ao ponto médio da base da nadadeira anal (Fig. 210); focinho relativamente longo e afilado, com comprimento pré-oral correspondendo de 1,2 a 1,8 vezes à distância internasal; origem da primeira nadadeira dorsal pouco anterior ou sobre o ápice das margens internas da nadadeira peitoral; sem crista dérmica interdorsal. Coloração dorsal cinzenta, exibindo tons levemente esverdeados; ventre branco; ápice das nadadeiras peitorais, dorsais e caudal levemente escurecidas.

Tamanho: presumivelmente não ultrapassa 1,5 $\mathrm{m}$ de comprimento total; maturidade sexual nos machos a partir de $71 \mathrm{~cm}$, e em fêmeas, com cerca de $80 \mathrm{~cm}$; nasce entre 31 e $40 \mathrm{~cm}$.

Distribuição, Hábitos e Biologia: distribuição restrita à costa atlântica e pacífica das Américas. No Brasil, ocorre da Ilha de Marajó (Pará) até Cananéia (São Paulo), raramente no Paraná. Encontrada sobre a plataforma continental em águas tropicais. Vive preferencialmente próxima ao fundo lamoso de regiões estuarinas, a profundidades de até $80 \mathrm{~m}$. Vivípara placentária, produz de quatro a onze filhotes por parto. Alimenta-se de crustáceos, pequenos peixes ósseos e, eventualmente, neonatos de tubarões (Rhizoprionodon e Sphyrna).

Observações: é a menor espécie do gênero na costa brasileira. Por apresentar menor porte, muitas vezes pode ser confundida com o cação-frango (Rhizoprionodon spp.). Diferencia-se pela ausência de sulco labial superior e de cristas pré-anais.

Carcharhinus limbatus (Müller \& Henle, 1839) (Fig. 211)

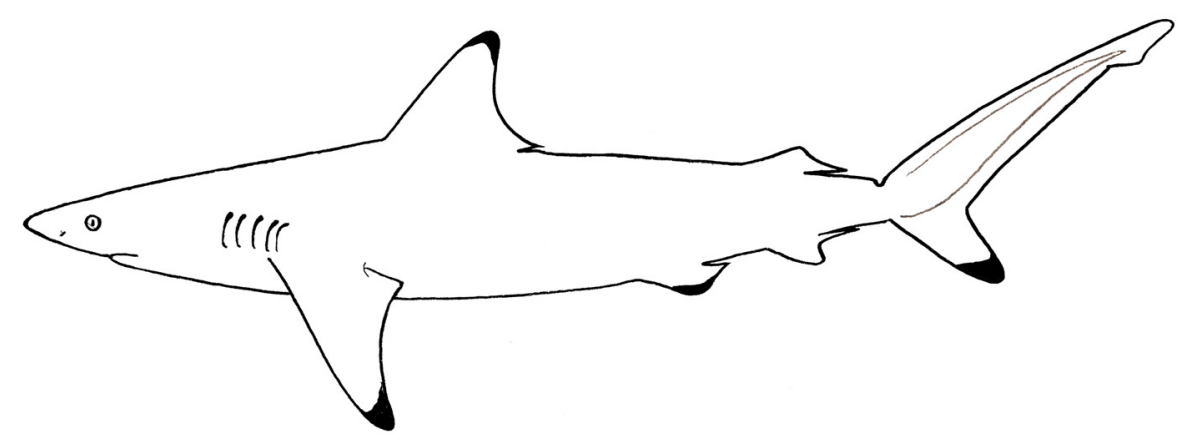


Nomes populares: galha-preta, sucuri, sucuri-de-galha-preta, corta-garoupa, serragaroupa.

Caracteres distintivos: primeira fenda branquial até 2,5 vezes maior que o diâmetro horizontal do olho, o qual cabe cerca de cinco vezes na distância pré-oral; focinho relativamente longo e afilado, com comprimento pré-oral correspondendo de 1,3 a 1,7 vezes a distância internasal; origem da primeira nadadeira dorsal sobre ou um pouco posterior à inserção da nadadeira peitoral; sem crista dérmica interdorsal. Coloração cinza ou castanha dorsalmente; manchas negras presentes no ápice das nadadeiras peitorais, segunda nadadeira dorsal, lobo inferior da nadadeira caudal, margens e lobo superior da primeira nadadeira dorsal.

Tamanho: CT máximo de cerca de 2,5 m; machos amadurecem entre 1,3 e 1,8 m de CT e fêmeas, entre 1,2 e 1,9 m de CT. Nascem medindo entre 38 e 72 cm de CT.

Distribuição, Hábitos e Biologia: distribui-se por todos os oceanos. No Brasil, encontra-se do Nordeste até Cananéia (Estado de São Paulo), e, eventualmente, mais ao sul. Vive na zona pelágica sobre a plataforma continental, em águas tropicais, subtropicais e temperadas. Encontrada até $60 \mathrm{~m}$ de profundidade, ocasionalmente até $80 \mathrm{~m}$. Vivípara placentária, parindo de um a dez filhotes por vez, com período de gestação podendo variar de dez a 12 meses. Alimenta-se de moluscos cefalópodes, crustáceos, diferentes espécies de peixes ósseos (de médio e grande porte), bem como de outros elasmobrânquios.

Observações: espécie potencialmente perigosa, com alguns registros de ataque a mergulhadores no mundo e, supostamente, no Brasil. Possivelmente, foi a espécie que atacou um mergulhador em novembro de 1999 na Baía de Guanabara - RJ, próximo à ponte Rio-Niterói.

Carcharhinus brevipinna (Müller \& Henle, 1839) (Fig. 212)

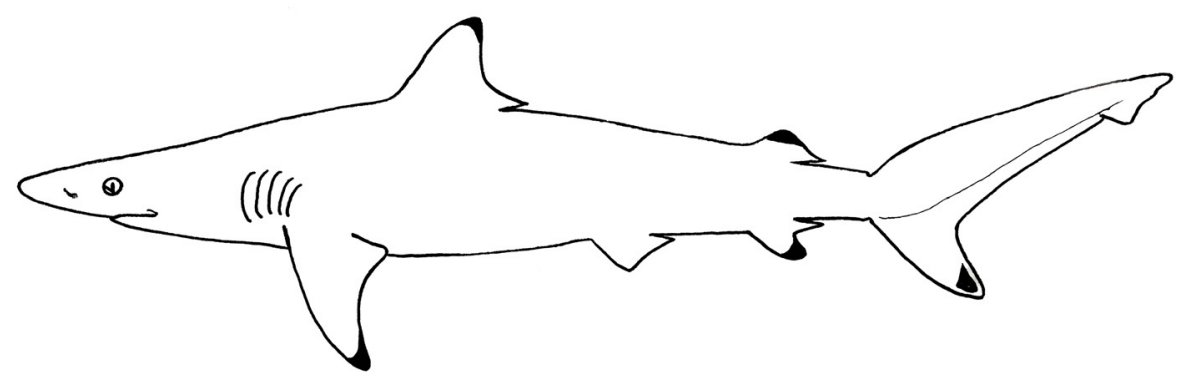

Nomes populares: galha-preta, saquari.

Caracteres distintivos: primeira fenda branquial quatro vezes maior (ou mais) que o diâmetro horizontal do olho; diâmetro horizontal do olho cabendo de sete a oito vezes na distância pré-oral; focinho relativamente longo e pontiagudo, com comprimento pré-oral correspondendo de 1,5 a 1,8 vezes a distância internasal; origem da primeira nadadeira dorsal sobre ou posterior à margem livre da nadadeira peitoral; sem crista dérmica interdorsal. Coloração cinza-bronzeada dorsalmente; espécimes entre 80 cm a um metro de CT apresentam manchas negras nas extremidades da segunda 
nadadeira dorsal, da nadadeira anal e do lobo inferior da nadadeira caudal. Nos exemplares com mais de 1,3 $\mathrm{m}$ de comprimento total, essas manchas estão presentes geralmente em todas as nadadeiras, exceto nas nadadeiras pélvicas. Exemplares recém-nascidos nem sempre têm as manchas negras evidentes.

Tamanho: CT máximo de cerca de 2,8 m; machos maduros entre 1,59 e dois metros e fêmeas, entre 1,7 e dois metros de CT. Nascem medindo de 60 a $75 \mathrm{~cm}$ de CT.

Distribuição, Hábitos e Biologia: distribui-se por todos os oceanos e é comum no Sudeste do Brasil. Vive em águas temperadas e tropicais, sobre a plataforma continental na zona pelágica até pelo menos $75 \mathrm{~m}$ de profundidade. Sabe-se que apresenta um comportamento aéreo, saltando acrobaticamente para fora do espelho d'agua. Vivípara placentária, parindo de três a 15 filhotes. Alimentação constituída principalmente por peixes ósseos.

Observações: é comum encontrar esses tubarões formando grandes cardumes. Em maio de 2005, um cardume de vinte exemplares (pesando entre 110 e $143 \mathrm{~kg}$ e medindo até dois metros) foi capturado por pescadores da Praia de Manguinhos, em BúziosRJ. Os peixes estavam a $200 \mathrm{~m}$ da costa da Ilha da Âncora, onde é rara a presença de turistas e banhistas. No mesmo período, cerca de 300 tubarões dessa espécie caíram na rede de pescadores de Arraial do Cabo - RJ. Os animais encontrados a quase $100 \mathrm{~m}$ da costa mediram, em média, 1,5 $\mathrm{m}$ de comprimento total e pesaram aproximadamente $80 \mathrm{~kg}$. O litoral da Região dos Lagos do Rio de Janeiro está na rota migratória desses tubarões, já que a oferta de alimento costuma ser maior nessa época do ano, em que vários peixes estão em fase de reprodução. Essa espécie é muitas vezes confundida com Carcharhinus limbatus, por ambas possuírem manchas negras nas extremidades das peitorais (razão pela qual são chamadas popularmente de galha-preta) e ausência de crista dérmica. Difere-se pela primeira fenda branquial maior em relação ao diâmetro horizontal do olho, diâmetro horizontal do olho cabendo mais vezes na distância pré-oral e origem da primeira dorsal localizada sobre, ou posteriormente à margem livre da peitoral (ver a chave para identificação da espécie).

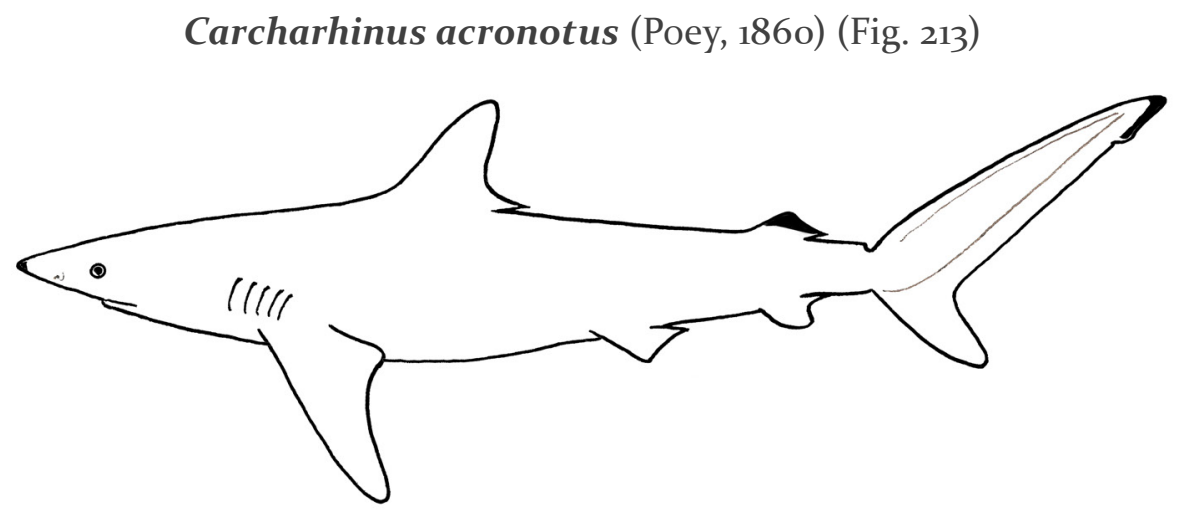

Nomes populares: flamengo, focinho-preto. 
Caracteres distintivos: focinho relativamente longo e arredondado, com comprimento pré-oral correspondendo de 1,4 a 1,7 vezes a distância internasal; origem da primeira nadadeira dorsal localizada sobre o ápice das margens internas das nadadeiras peitorais; segunda nadadeira dorsal de tamanho reduzido, com comprimento de sua base correspondendo a $1 / 3$ da base da primeira nadadeira dorsal; sem crista dérmica interdorsal. Coloração do corpo dorsalmente é cinzenta com tons de castanho claro e bege, podendo apresentar uma macha escura na extremidade da segunda nadadeira dorsal e no lobo superior da nadadeira caudal: exibe uma mancha negra característica na ponta do focinho.

Tamanho: CT máximo estimado em 1,4 m; machos tornam-se maduros com 97 a 1,1 cm de CT, e fêmeas, com cerca de um metro de CT. Nascem com o tamanho variando entre 38 e $50 \mathrm{~cm}$ de CT.

Distribuição, Hábitos e Biologia: distribuição no Oceano Atlântico Ocidental desde a Carolina do Norte (EUA) até, pelo menos, o litoral do Paraná, sul do Brasil. Vive sobre a plataforma continental, alcançando profundidades de até $80 \mathrm{~m}$. Vivípara plancentária, produz de dois a seis filhotes por parto. Alimenta-se de pequenos peixes ósseos e, em menor escala, de invertebrados.

Observações: muito raro no Sudeste e Sul do Brasil.

Carcharhinus obscurus (Le Sueur, 1818) (Fig. 214)

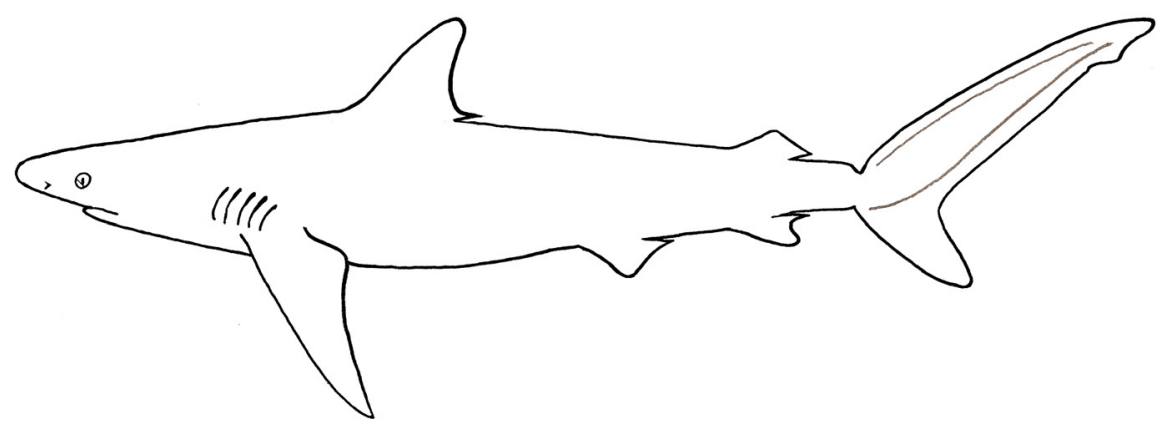

Nomes populares: cação-baía, fidalgo, estrela.

Caracteres distintivos: focinho relativamente curto e arredondado, com comprimento pré-oral correspondendo de um a 1,4 vezes a distância internasal; origem da primeira nadadeira dorsal sobre ou um pouco anterior ao ápice das margens internas das nadadeiras peitorais; crista dérmica interdorsal presente. Coloração cinza ou castanha dorsalmente; ventre branco; os ápices das nadadeiras podem ser mais escurecidos, mas não negros.

Tamanho: uma das maiores espécies de Carcharhinus, alcançando o CT máximo de aproximadamente quatro metros; os indivíduos machos tornam-se maduros a partir de 2,8 m de CT e fêmeas, entre 2,5 e $3 \mathrm{~m}$ de CT. Nascem medindo entre $70 \mathrm{~cm}$ e um metro de CT.

Distribuição, Hábitos e Biologia: distribuição em áreas costeiras e oceânicas do mundo inteiro. Ocorre em toda a costa brasileira. Vive na zona pelágica em águas 
tropicais, subtropicais e temperadas até cerca de $400 \mathrm{~m}$ de profundidade. Reprodução por viviparidade placentária, nascem de três a 14 filhotes por parto, e seu período de gestação varia de sete a oito meses. Alimentação principalmente constituída de peixes ósseos, outros elasmobrânquios e carcaças de mamíferos marinhos.

Observações: esse grande tubarão oceânico e costeiro é ocasionalmente capturado por barcos espinheleiros que operam no Sudeste e Sul do Brasil. Entretanto, sua identificação é extremamente difícil, principalmente por ser confundido com outros grandes Carcharhinus, como C. galapagensis e C. plumbeus.

Carcharhinus plumbeus (Nardo, 1827) (Fig. 215)

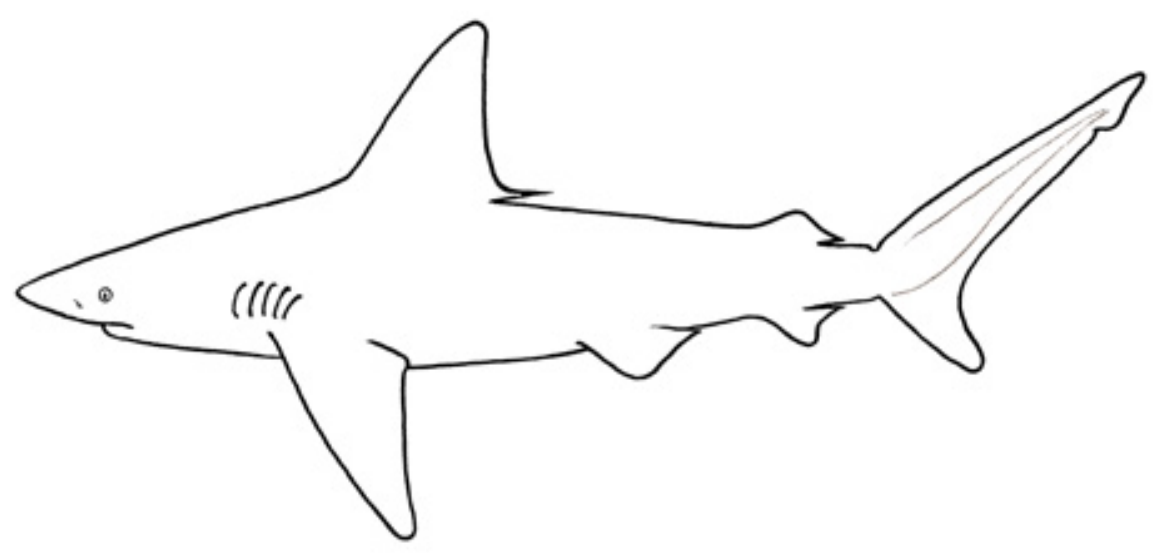

Nomes populares: cação-baía, cação-galhudo, barriga-d'água.

Caracteres distintivos: focinho relativamente curto e arredondado, com comprimento pré-oral correspondendo de o,9 a 1,3 vezes a distância internasal; primeira nadadeira dorsal alta, sua altura igual ou maior que a metade da distância entre a ponta do focinho e esta nadadeira, com sua origem sobre a inserção das nadadeiras peitorais; segunda nadadeira dorsal com comprimento de sua base, contida aproximadamente três vezes na base da primeira nadadeira dorsal; crista dérmica interdorsal presente. Coloração cinza ou castanha no dorso; ventre branco, ocasionalmente com as margens posteriores das nadadeiras mais escurecidas, mas não negras.

Tamanho: atinge cerca de três m de CT; machos tornam-se maduros entre 1,3 e 1,8 $\mathrm{m}$ de CT e fêmeas, entre 1,4 e 1,8 m de CT. Nascem medindo entre 56 e $75 \mathrm{~cm}$ de CT. Distribuição, Hábitos e Biologia: distribui-se em todos os oceanos. No Brasil, ocorre ao longo de toda a costa. Essa espécie é encontrada sobre a plataforma continental em águas tropicais e temperadas, até profundidades de pelo menos 280 m. Vivípara placentária, parindo de um a 14 filhotes, e seu período de gestação varia de oito a 12 meses. Alimentação constituída basicamente de moluscos cefalópodes, crustáceos, pequenos peixes ósseos bentônicos e, mais raramente, presas maiores, como pequenos golfinhos. 
Observações: outro grande Carcharhinus que pode ser confundido com alguns de seus congêneres, como C. galapagensis, $C$. obscurus e $C$. leucas.

Carcharhinus leucas (Müller \& Henle, 1839) (Fig. 216)

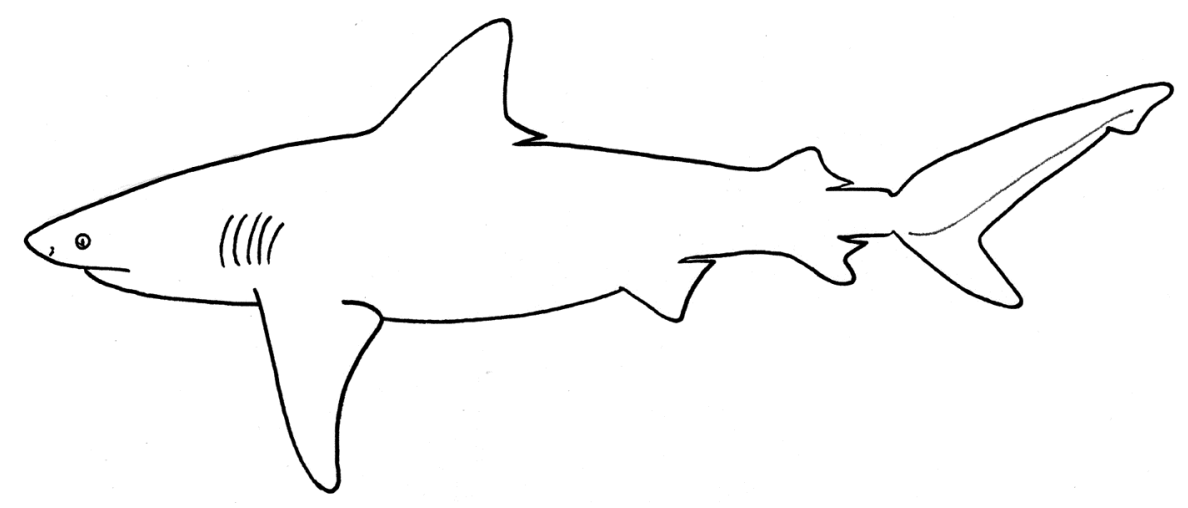

Nome popular: tubarão-cabeça-chata.

Caracteres distintivos: focinho relativamente curto e arredondado, com comprimento pré-oral correspondendo de o,7 a uma vez a distância internasal; origem da primeira nadadeira dorsal sobre ou pouco posterior à inserção das nadadeiras peitorais (Fig. 206); sem crista dérmica interdorsal. Coloração cinza clara ou escura no dorso (às vezes com tons de castanho); mais clara no ventre, com nadadeiras mais escurecidas nas margens (principalmente em juvenis).

Tamanho: estima-se que pode chegar aos 3,4 $\mathrm{m}$ de CT; machos amadurecem entre 1,57 e 2,26 m, e fêmeas, entre 1,8 e 2,3 m de CT. Nascem com o tamanho variando entre 56 e $81 \mathrm{~cm}$ de CT.

Distribuição, Hábitos e Biologia: espécie costeira em todos os oceanos, ocorrendo em águas tropicais a temperadas. Distribui-se desde New York (EUA) até São Paulo (Brasil). Encontrada desde águas rasas (menos de $30 \mathrm{~m}$ de profundidade) a águas mais profundas (com pelo menos $152 \mathrm{~m}$ ). Pode penetrar livremente em água doce, havendo registros de sua jornada em grandes rios e lagos do mundo. Essa espécie é vivípara placentária, nascendo de um a 13 filhotes por parto. Alimenta-se de grande diversidade de organismos, desde invertebrados, peixes ósseos e elasmobrânquios, podendo atacar ainda tartarugas, mamíferos e aves marinhas. Em água doce, já foram registrados ataques contra mamíferos terrestres, como hipopótamos.

Observações: possivelmente a mais perigosa espécie de tubarão a seres humanos, juntamente com o tubarão-tigre (Galeocerdo cuvier). Oficialmente mais de 110 ataques no mundo, com 23 mortes. A maioria dos registros ocorreu em áreas costeiras tropicais, incluindo em grandes rios e lagos. Também é a principal espécie responsável pelos ataques de tubarões ocorridos na Região Metropolitana de Recife, nos últimos 15 anos. Oficialmente nenhum caso comprovado causado por essa espécie no Rio de Janeiro.

Observação: em outubro de 2019, dois filhotes foram capturados no fundo da Baía de Guanabara, em Magé - RJ (confirmado por meio de fotografias). 


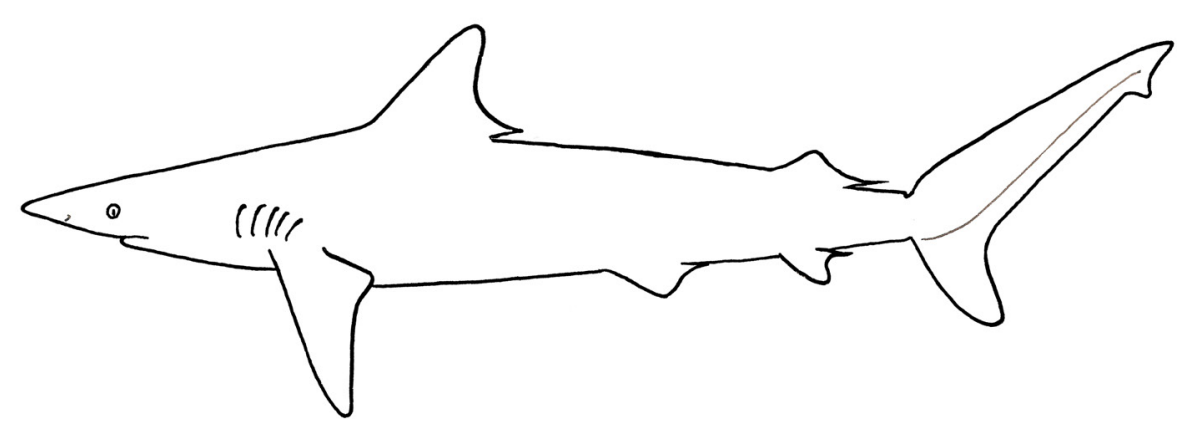

Nome popular: tubarão-azeiteiro, tubarão-toninha

Caracteres distintivos: focinho longo e afilado, com comprimento pré-oral correspondendo de 1,7 a 1,9 vezes a distância internasal; origem da primeira nadadeira dorsal sobre o ápice das margens internas das nadadeiras peitorais; crista dérmica interdorsal presente. Coloração cinza clara ou escura variando em tons castanhos no dorso (por vezes com pequenas manchas enegrecidas espalhadas pelo corpo); ventre mais claro que o dorso.

Tamanho: alcança os 2,8 m de CT; machos amadurecem com cerca de 1,5 m de CT, e fêmeas com cerca de 1,6 m de CT. Nascem com o tamanho aproximado de $60 \mathrm{~cm}$ de CT.

Distribuição, Hábitos e Biologia: distribuição restrita ao Oceando Atlântico Ocidental e Oriental. Encontrada desde águas tropicais a temperadas, podendo ocorrer na região oceânica ou sobre a plataforma continental, em profundidades entre 50 e $100 \mathrm{~m}$. Possui hábitos noturnos. Vivípara placentária, produz de quatro a 16 filhotes por parto. Alimenta-se de moluscos cefalópodes (lulas) e pequenos peixes ósseos.

Observações: pode ser confundida com C. falciformis, mas difere desta, principalmente, pela forma do dente, pelo comprimento do focinho (um pouco mais longo) e pela coloração dos olhos, mais esverdeada.

\section{Carcharhinus falciformis (Müller \& Henle, 1939) (Fig. 218)}

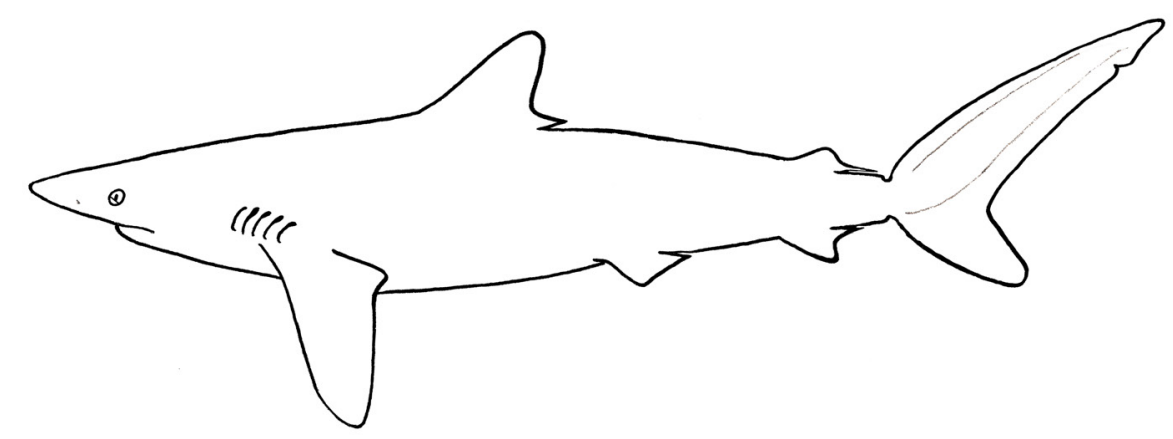

Nomes populares: lombo-preto, cação-baía. 
Caracteres distintivos: focinho relativamente longo e arredondado, com comprimento pré-oral correspondendo de 1,2 a 1,6 vezes a distância internasal; origem da primeira nadadeira dorsal posterior à margem livre da nadadeira peitoral; crista dérmica interdorsal presente. Coloração cinza escura ou castanha escura no dorso; claro no ventre, com ápices das nadadeiras escurecidos (mas não negros).

Tamanho: CT máximo de cerca de 3,3 m; machos maduros entre 1,87 e 2,17 m CT, e fêmeas, entre 2,13 e 2,3 m CT; nasce medindo entre 70 a $87 \mathrm{~cm}$ de CT.

Distribuição, Hábitos e Biologia: distribuição cosmopolita, preferencialmente em águas tropicais na região oceânica, mas podendo ser encontrada também na região costeira, em águas subtropicais e temperadas. É mais comum próxima à superfície, mas pode atingir grandes profundidades (pelo menos $500 \mathrm{~m}$ ). Nascem de dois a 14 filhotes por parto e o período de gestação é estimado em 12 meses. Alimentação constituída de diferentes espécies de peixes ósseos pelágicos e costeiros.

Observações: uma das espécies de tubarões oceânicos mais abundantes. Pode ser confundida com $C$. signatus, mas se difere, principalmente, pela forma do dente, pelo comprimento do focinho (um pouco mais curto) e pela coloração dos olhos, que é mais amarelada.

Carcharhinus brachyurus (Günther, 1870) (Fig. 219)

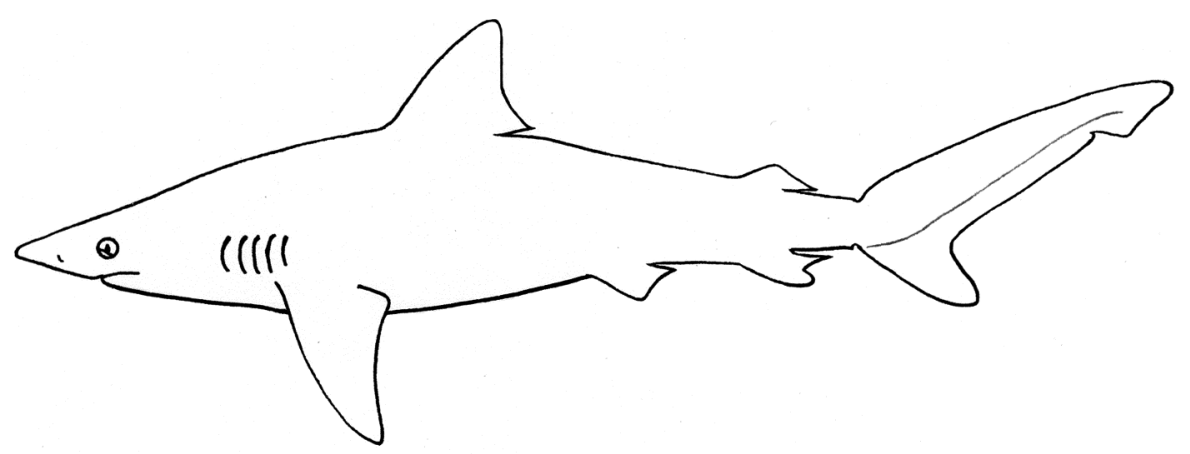

Nome popular: cação-baía.

Caracteres distintivos: focinho relativamente longo e arredondado, com comprimento pré-oral correspondendo de 1,1 a 1,4 vezes a distância internasal; nadadeiras peitorais longas, com comprimento de suas margens anteriores mais de tres vezes o comprimento das margens anteriores das nadadeiras pélvicas; origem da primeira nadadeira dorsal sobre ou anterior à margem livre da nadadeira peitoral; crista dérmica interdorsal geralmente ausente (pode estar presente em alguns exemplares). Coloração cinza-bronzeada dorsalmente; espécimes jovens apresentam manchas escuras na face ventral da nadadeira peitoral, bem como no ápice das nadadeiras dorsais e no lobo superior da nadadeira caudal.

Tamanho: CT máximo de 2,9 m; machos tornam-se maduros entre dois e 2,29 $\mathrm{m}$ de CT e fêmeas, a partir de 2,4 m de CT. Nascem com cerca de 59 a $67 \mathrm{~cm}$ de CT.

Distribuição, Hábitos e Biologia: espécie encontrada em todos os oceanos de águas temperadas a tropicais. No Oceano Atlântico Ocidental, ocorre do Rio de Janeiro até 
a Argentina. Vive na zona pelágica de regiões costeiras e oceânicas, até cerca de $100 \mathrm{~m}$ de profundidade. Nascem de 13 a 20 filhotes por vez. Alimenta-se de grande variedade de peixes ósseos, incluindo também alguns tubarões e raias.

Observações: muito comum nas capturas por espinhéis oceânicos ao largo da costa uruguaia, mas sua abundância populacional aparentemente diminui nas baixas latitudes. O Rio de Janeiro corresponde ao registro mais ao norte no Oceano Atlântico Ocidental. Há relatos de sua ocorrência ao largo do Norte e Nordeste do Brasil. Entretanto esses dados precisam ser confirmados, uma vez que $C$. brachyurus é uma das espécies de Carcharhinus mais difíceis de serem identificadas.

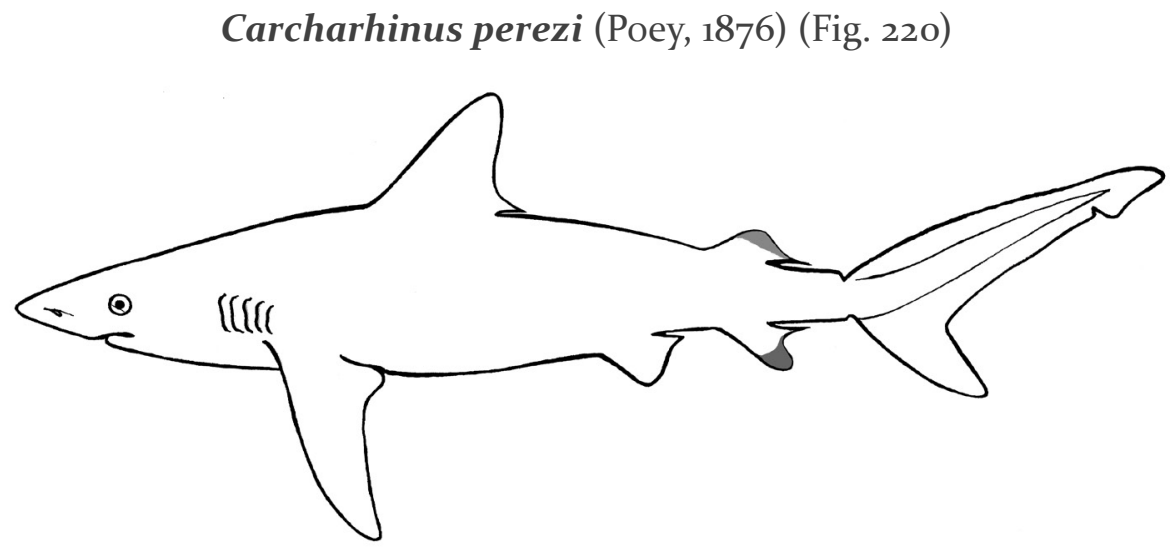

Nome popular: tubarão-caribenho-dos-recifes, tubarão cabeça-de-cesto

Caracteres distintivos: Origem da primeira nadadeira dorsal sobre ou anterior à margem livre da nadadeira peitoral. Focinho curto, arredondado e largo; distância internasal cabendo cerca de um a 1,1 vezes no comprimento pré-oral. Dentes superiores com bordas finamente serrilhadas; nunca mais de 13 dentes de cada lado da sínfise superior. Coloração variando de acindentada a castanho clara dorsalmente, com extremidade das nadadeiras peitorais mais escura. Região ventral clara.

Tamanho: Espécie considerada de grande porte, atingindo três metros de CT. Machos adultos alcançam, 1,7 m de CT. Nascem com cerca de $70 \mathrm{~cm}$ de CT.

Distribuição, Hábitos e Biologia: Amplamente distribuída na plataforma continental no Oceano Atlântico Ocidental, em profundidades entre 15 a 80 metros. Essa espécie está associada aos recifes e ilhas oceânicas. No Brasil é encontrada principalmente no Nordeste. Um embrião a termo capturado no Rio de Janeiro foi observado, sem maiores detalhes (Gadig et al., 1996; Garla et al., 2006). Sua alimentação é principalmente composta por peixes ósseos.

\section{Família SPHYRNIDAE}

Caracterizada pela cabeça expandida lateralmente. Apresenta dois gêneros (Eusphyra e Sphyrna), mas apenas um está presente no Brasil (Sphyrna). 


\section{Gênero Sphyrna}

Das nove espécies distribuídas no mundo, seis são registradas no Brasil e também na costa do Estado do Rio de Janeiro (Sphyrna tiburo, S. tudes, S. media, $S$. zygaena, $S$. mokarran e $S$. lewini). As três primeiras não crescem mais do que $1,5 \mathrm{~m}$ de comprimento, e as demais alcançam mais do que três metros de CT. A identificação entre as espécie é feita, principalmente, com base na morfologia da silhueta da cabeça (Figs. 221 e 223).

\section{Chave para Identificação das Espécies do Gênero Sphyrna}

1a. Contorno anterior da cabeça sem ondulações (Figs. 221 e 235); dentes posteriores molariformes, com cúspide baixa (Fig. 222).

Sphyrna tiburo

1b. Contorno anterior da cabeça com ondulações (levemente esboçadas em $S$. media) (Fig. 223); dentes posteriores não molariformes, com cúspides pontiagudas (Fig. 224)......2 2a. Extremidade do prolongamento posterior da primeira nadadeira dorsal situada sobre ou posterior à origem da nadadeira pélvica; nadadeira anal não falcada (Fig. 225, seta)...3 2b. Extremidade do prolongamento posterior da primeira nadadeira dorsal situada nitidamente anterior à origem da nadadeira pélvica; nadadeira anal falcada (Fig. 226, seta)

3a. Sulco nasal interno presente (Fig. 227, seta A); contorno anterior da cabeça com entalhe mediano presente (Fig. 227, seta B)

Sphyrna tudes 3b. Sulco nasal interno ausente (Fig. 228, seta A); contorno anterior da cabeça com entalhe mediano ausente ou mal definido (Fig. 228, seta B). Sphyrna media 4a. Sem entalhe na região mediana do contorno anterior da cabeça (Fig. 229).....

Sphyrna zygaena

4b. Com entalhe na região mediana do contorno anterior da cabeça (Fig. 230). 5 5a. Ausência de sulco nasal interno; dentes fortemente serrilhados em indivíduos de qualquer tamanho (Fig. 231); comprimento da margem anterior da segunda nadadeira dorsal maior que o comprimento da margem anterior da nadadeira anal (Fig. 232).

Sphyrna mokarran

5b. Presença de sulco nasal interno; dentes lisos, às vezes fracamente serrilhados em indivíduos de grande porte (mais de 1,8 m CT) (Fig. 233); margem anterior da segunda nadadeira dorsal menor que o comprimento da margem anterior da nadadeira anal (Fig. 234)......

Sphyrna lewini 


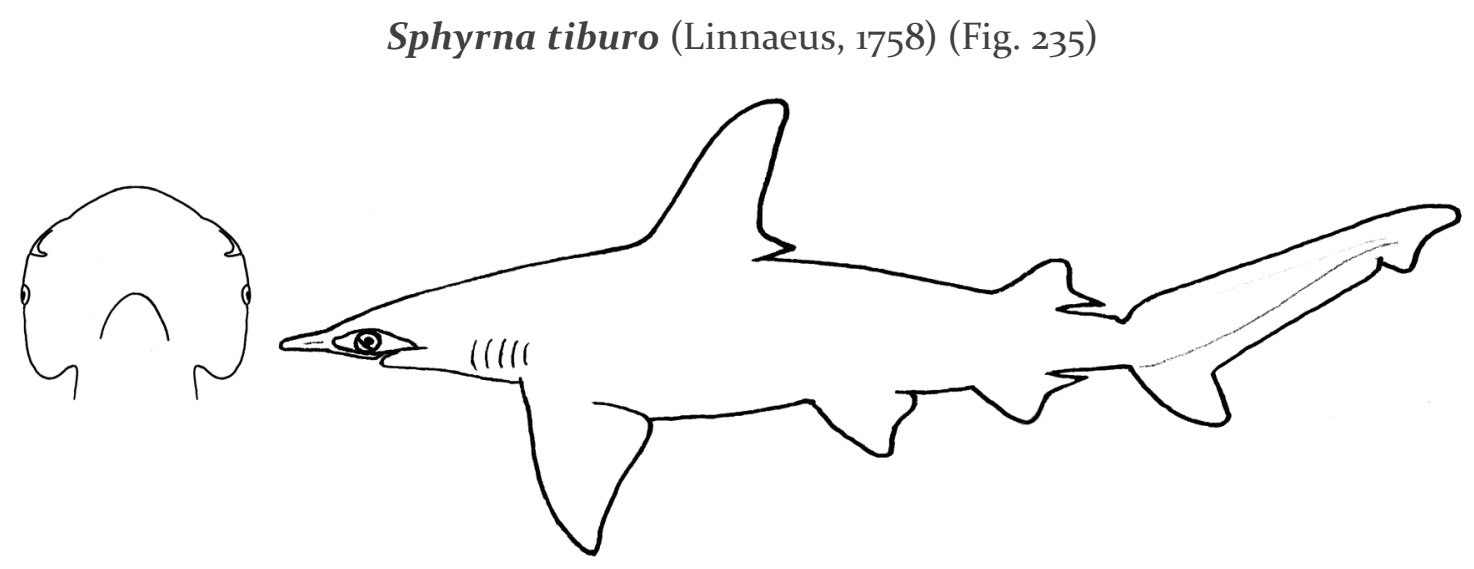

Nomes populares: tubarão-martelo, cação-martelo, pata.

Caracteres distintivos: cabeça sem entalhe em sua região mediana, com contorno anterior circular e com largura correspondendo a cerca de 18 a $22 \%$ do CT do corpo; sulco nasal interno ausente; comprimento pré-oral equivalendo a 2/5 da largura da cabeça; dentes posteriores achatados e molariformes; origem da segunda nadadeira dorsal posterior à origem da nadadeira anal, com comprimento de sua base correspondendo aproximadamente à metade da primeira nadadeira dorsal; nadadeira anal não falcada. Coloração castanha clara no dorso podendo apresentar pequenas manchas negras; mais clara no ventre do que no dorso.

Tamanho: CT máximo registrado de 1,3 m; maturação ocorre entre os 52 e $75 \mathrm{~cm}$ de CT nos machos e entre os 80 e $85 \mathrm{~cm}$ de CT nas fêmeas; comprimento ao nascer varia entre 33 e $37 \mathrm{~cm}$ de CT.

Distribuição, Hábitos e Biologia: distribuição na costa oriental do Oceano Pacífico e costa ocidental do Oceano Atlântico. Encontrada sobre a plataforma continental, principalmente em águas tropicais (menos freqüente em regiões subtropicais e temperadas), entre dez e $25 \mathrm{~m}$ de profundidade, (podendo atingir $80 \mathrm{~m}$ ). A gestação é do tipo vivípara placentária, nascendo de três a 23 filhotes por vez. Alimentação constituída principalmente de moluscos bivalves, crustáceos e pequenos peixes ósseos.

Observações: considerada extinta para o município do Rio de Janeiro, de acordo com a listagem de fauna ameaçada em extinção (Buckup et al., 200o). Sua população foi numerosa no Sudeste do Brasil até, pelo menos, a década de 1970. Exemplares de até $60 \mathrm{~cm}$ de $C T$ podem ser confundidos com $S$. media devido ao formato da cabeça. No entanto, esta se diferencia com o crescimento. 


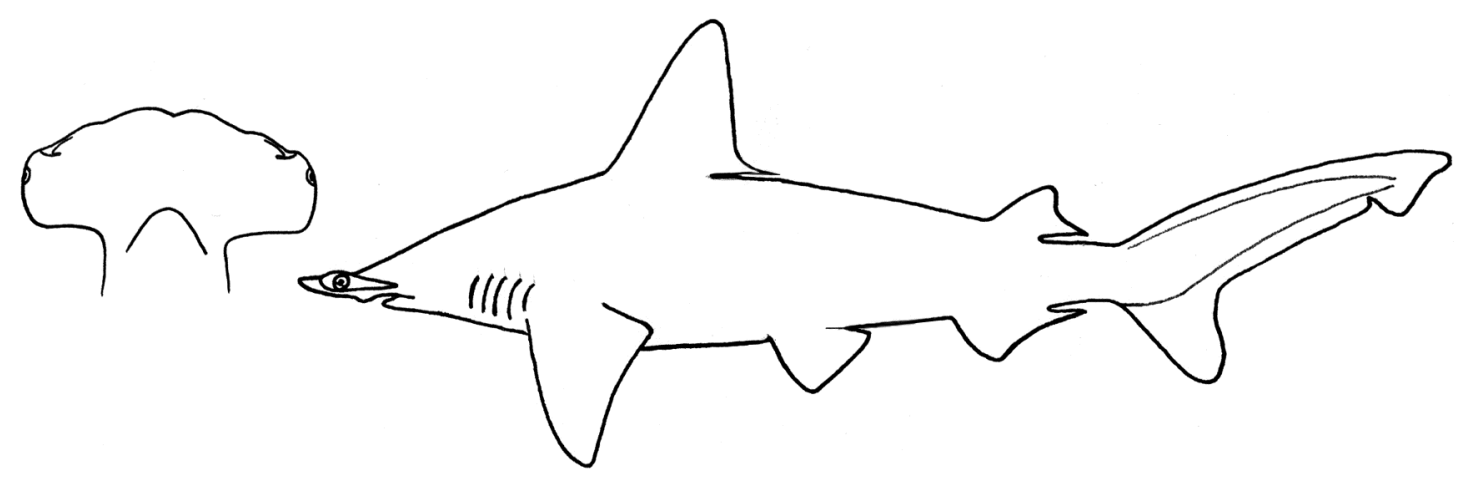

Nomes populares: tubarão-martelo, cação-martelo, chapéu-armado.

Caracteres distintivos: cabeça com entalhe em sua região mediana, com largura correspondendo a cerca de 28 a $32 \%$ do comprimento total do corpo; sulco nasal interno presente; comprimento pré-oral equivalendo a $1 / 3$ da largura da cabeça; origem da segunda nadadeira dorsal sobre o ponto médio da base da nadadeira anal, com comprimento de sua base correspondendo aproximadamente à metade da primeira nadadeira dorsal; nadadeira anal não falcada. Coloração cinza clara no dorso, muitas vezes com tons amarelados dourados; mais clara no ventre do que no dorso.

Tamanho: CT máximo de 1,5 m; maturação ocorre nos machos entre os 85 e $93 \mathrm{~cm}$ de CT, e nas fêmeas, a partir de $97 \mathrm{~cm}$ CT; comprimento ao nascer de aproximadamente $30 \mathrm{~cm}$ de CT.

Distribuição, Hábitos e Biologia: distribui-se principalmente na costa atlântica da América do Sul. Vive sobre a plataforma continental, preferencialmente em águas tropicais, mas pode ser encontrada em águas temperadas. Sua distribuição vertical varia de águas rasas até $80 \mathrm{~m}$ de profundidade. A geração de filhotes se dá por viviparidade placentária, variando de cinco a 19 embriões. Alimentação composta por crustáceos, moluscos e peixes ósseos.

Observações: considerada extinta para o município do Rio de Janeiro, de acordo com a listagem de fauna ameaçada em extinção (Buckup et al., 20oo). Já foi mais abundante no Sudeste do Brasil até, pelo menos, a década de 70. A coloração dourada do corpo é atribuída aos hábitos alimentares, que incluem espécies de peixes e crustáceos de coloração amarelada cuja carne é rica em caroteno. 


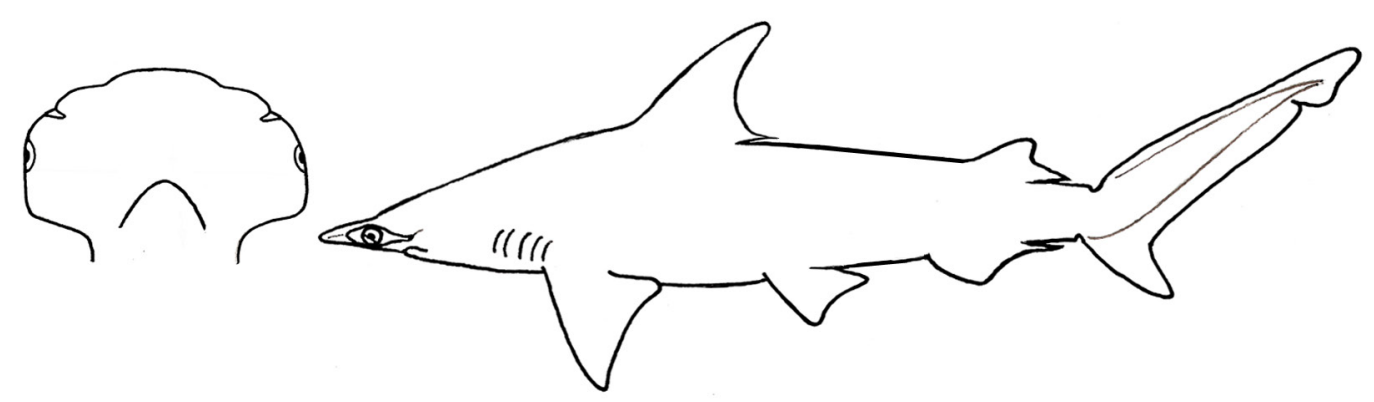

Nomes populares: tubarão-martelo, cação-martelo, pana.

Caracteres distintivos: cabeça sem entalhe em sua região mediana, com largura correspondendo a menos de $23 \%$ do comprimento total do corpo; sulco nasal interno ausente (às vezes levemente esboçado); comprimento pré-oral equivalendo de 1/3 a 2/5 da largura da cabeça; origem da segunda nadadeira dorsal sobre o ponto médio da base da nadadeira anal, com comprimento de sua base correspondendo a pouco menos da metade da primeira nadadeira dorsal; sulcos pré-caudais presentes no pedúnculo caudal; lobo terminal evidente na nadadeira caudal; nadadeira anal não falcada. Coloração entre cinza e castanha-amarelada no dorso; mais clara no ventre do que no dorso.

Tamanho: CT máximo estimado em 1,4 m; nasce com $31 \mathrm{~cm}$ aproximadamente.

Distribuição, Hábitos e Biologia: distribui-se na costa oriental do Oceano Pacífico e costa Ocidental do Atlântico. Encontrada sobre a plataforma continental até cerca de $65 \mathrm{~m}$ de profundidade. Espécie vivípara placentária, com apenas uma fêmea grávida já registrada, carregando 11 embriões. Estima-se que sua dieta alimentar seja constituída de crustáceos e peixes ósseos.

Observações: considerada extinta para o município do Rio de Janeiro, de acordo com a listagem de fauna ameaçada em extinção (Buckup et al., 200o). Já foi mais abundante no Sudeste do Brasil, até a década de 1970. Exemplares de até $60 \mathrm{~cm}$ de CT podem ser confundidos com $S$. tiburo.

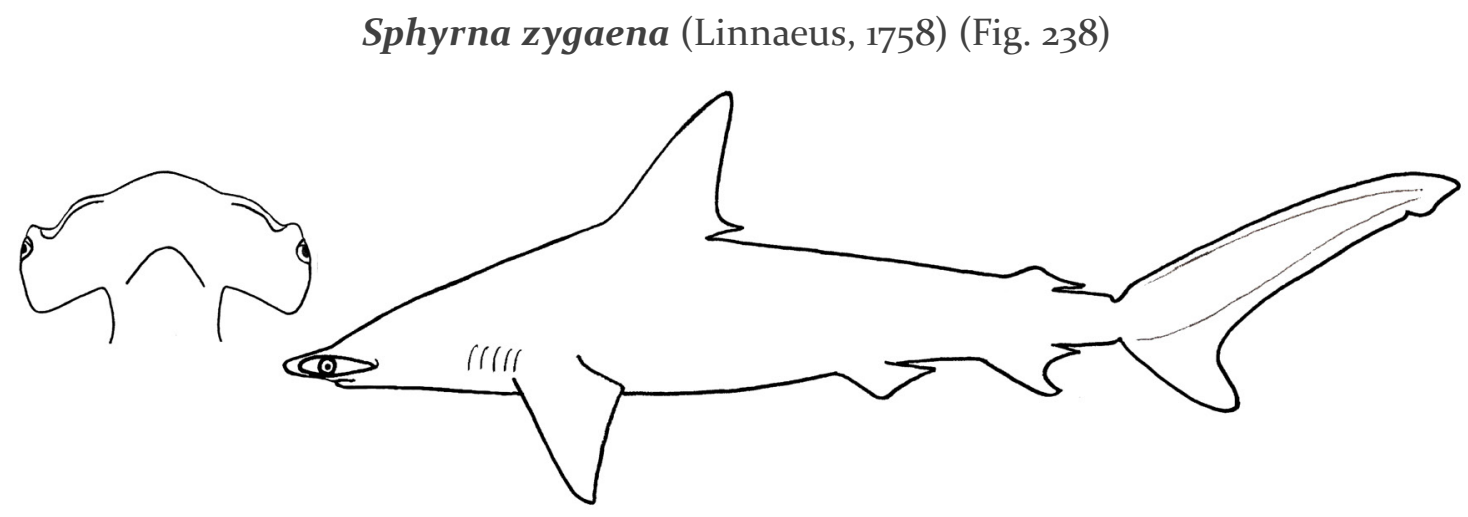

Nomes populares: tubarão-martelo, cação-martelo, cornudo. 
Caracteres distintivos: cabeça sem entalhe em sua região mediana, com largura correspondendo a cerca de 26 a $29 \%$ do comprimento total do corpo; sulco nasal interno presente; comprimento pré-oral correspondendo de $1 / 3$ a $1 / 5$ da largura da cabeça; origem da segunda nadadeira dorsal sobre a origem da nadadeira anal, com comprimento de sua base correspondendo a $1 / 3$ da base da primeira nadadeira dorsal; nadadeira anal falcada. Coloração castanha ou cinza escura no dorso; mais clara no ventre do que no dorso; jovens com manchas escuras na parte ventral das nadadeiras peitorais.

Tamanho: CT máximo de quatro metros; maturação ocorre em machos e fêmeas entre 1,8 e 2,4 m de CT; comprimento ao nascer entre 50 e $60 \mathrm{~cm}$ de CT.

Distribuição, Hábitos e Biologia: distribuição cosmopolita em águas temperadas e tropicais. Encontrada desde a costa à região oceânica, até $15 \mathrm{~m}$ de profundidade. A reprodução se dá por viviparidade placentária, gerando de 29 a 30 embriões por gestação. Alimentação constituída desde invertebrados (moluscos e crustáceos) até peixes ósseos e elasmobrânquios.

Observações: assim como outras espécies de tubarões-martelo de grande porte $(S$. lewini e $S$. mokarran), é tida como potencialmente perigosa. Considerada vulnerável no município do Rio de Janeiro, de acordo com a listagem de fauna ameaçada em extinção (Buckup et al., 200o). Bastante capturada na costa brasileira (porém menos que $S$. lewini), e também no litoral do Rio de Janeiro (principalmente os recémnascidos e jovens).

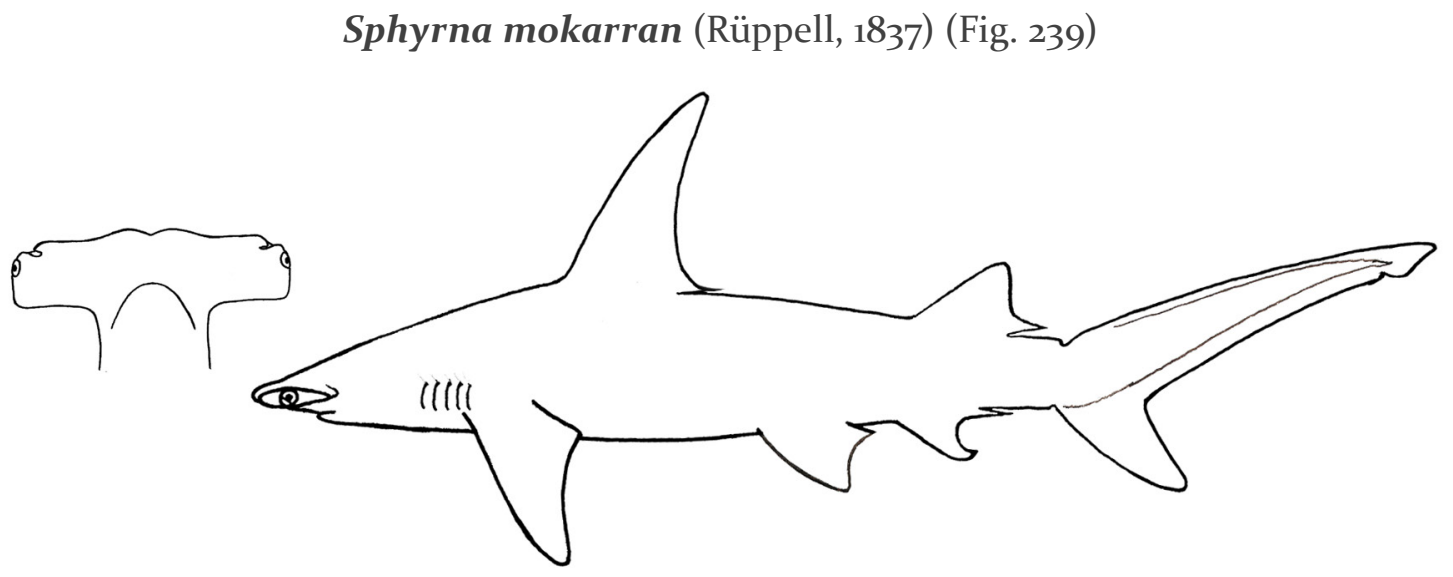

Nomes populares: tubarão-martelo, cação-martelo, panã.

Caracteres distintivos: cabeça com entalhe em sua região mediana, com largura correspondendo a cerca de 23 a $27 \%$ do comprimento total do corpo; sulco nasal interno ausente ou pouco desenvolvido; comprimento pré-oral equivalendo a $1 / 3$ da largura da cabeça; origem da segunda nadadeira dorsal sobre a origem da nadadeira anal, comprimento de sua base correspondendo aproximadamente à metade da primeira nadadeira dorsal; nadadeira anal falcada com manchas escuras na superfície ventral das nadadeiras peitorais. 
Tamanho: CT máximo registrado de 6,1 m; a maturação ocorre entre 2,3 e 2,6 m de CT nos machos, e entre 3,5 e 2,6 m de CT nas fêmeas; o comprimento ao nascer é estimado entre 50 e $70 \mathrm{~cm}$ de CT.

Distribuição, Hábitos e Biologia: distribuição em todos os oceanos, de águas tropicais a temperadas, em regiões costeiras e oceânicas na zona pelágica, até 80 $\mathrm{m}$ de profundidade, aproximadamente. No Brasil, é aparentemente mais comum no Norte e Nordeste. Espécie vivípara placentária, gera de 13 a 42 filhotes por vez, e seu período de gestação varia de sete a 12 meses (de acordo com a região geográfica). Sua dieta é constituída de crustáceos (caranguejos), cefalópodes (lulas), peixes ósseos e mesmo de outros elasmobrânquios, principalmente raias da família Dasyatidae.

Observações: considerada vulnerável para o município do Rio de Janeiro, de acordo com a listagem de fauna ameaçada em extinção (Buckup et al., 200o). É a maior espécie de tubarão-martelo, e potencialmente perigosa pelos mesmos motivos que S. zygaena e S. lewini (grande porte e hábitos costeiros). Possivelmente envolvida em alguns ataques a banhistas, em águas costeiras de regiões tropicais.

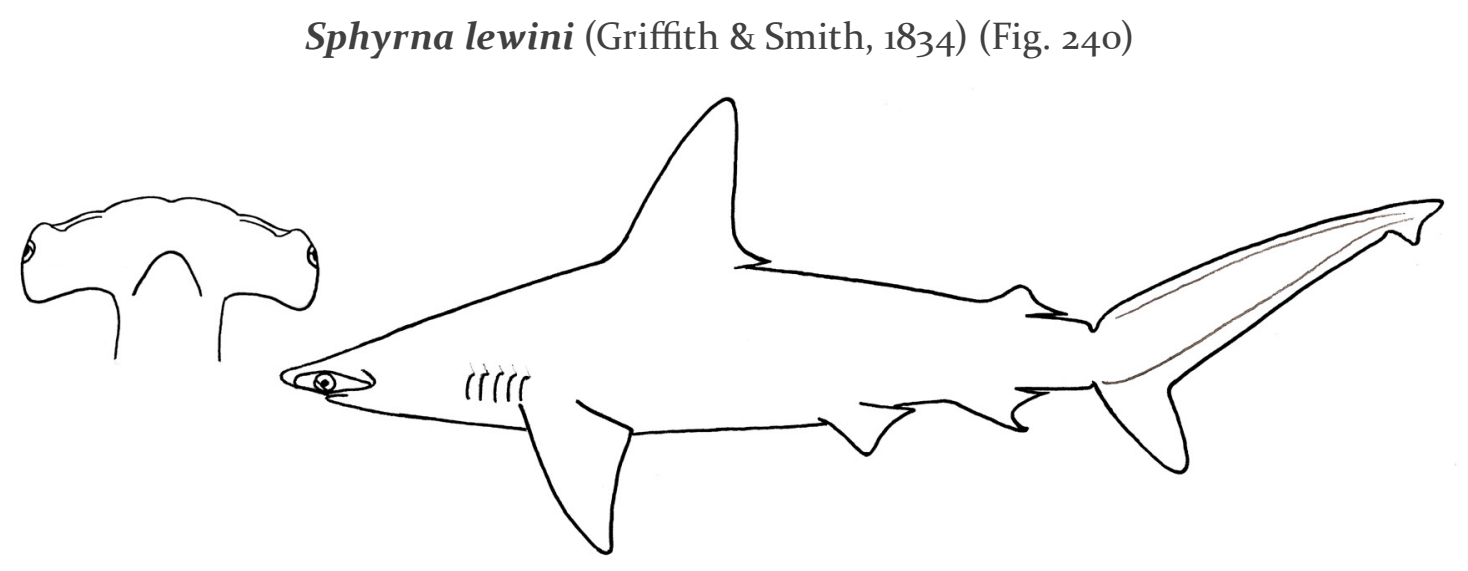

Nomes populares: tubarão-martelo, cação-martelo, panã, cambeva.

Caracteres distintivos: cabeça com entalhe em sua região mediana e com largura correspondendo de 24 a $30 \%$ do comprimento total do corpo; sulco nasal interno presente e bem desenvolvido; comprimento pré-oral equivalendo de $1 / 3$ a 1/5 da largura da cabeça; origem da segunda nadadeira dorsal sobre o ponto médio da base da nadadeira anal, com comprimento de sua base correspondendo a cerca de $1 / 3 \mathrm{da}$ base da primeira nadadeira dorsal; nadadeira anal falcada. Coloração entre cinza e castanha no dorso; mais clara no ventre do que no dorso; jovens com manchas escuras na superfície ventral das nadadeiras peitorais.

Tamanho: CT máximo estimado em 3,5 m; machos amadurecem entre 1,4 e 1,6 m de CT e fêmeas, a partir dos dois metros de CT; nasce entre 45 e $50 \mathrm{~cm}$ de CT.

Distribuição, Hábitos e Biologia: distribuição por todos os oceanos, de águas tropicais a temperadas, normalmente na zona pelágica sobre a plataforma continental. Pode ocorrer até $275 \mathrm{~m}$ de profundidade. A sua reprodução se faz por viviparidade placentária, gerando de 13 a 48 filhotes por vez. O período de gestação 
varia de nove a dez meses. Alimentação composta principalmente por peixes ósseos e ocasionalmente por pequenos elasmobrânquios.

Observações: é a espécie de tubarão-martelo mais abundante do mundo, e potencialmente perigosa devido a seu grande porte e hábitos costeiros em águas rasas. É a espécie mais capturada da costa brasileira. Considerada vulnerável para o município do Rio de Janeiro, de acordo com a listagem de fauna ameaçada em extinção (Buckup et al., 200o).

\section{AS RAIAS DO RIO DE JANEIRO}

\section{Chave para Identificação das Ordens de Raias}

1a. Formato do disco arredondado; órgãos elétricos concentrados na região da base das nadadeiras peitorais, próximo às brânquias, com o formato de feijão (Fig. 241)...

TORPEDINIFORMES

1b. Formato do disco nunca arredondado; órgãos elétricos ausentes (Fig. 242)............2 2a. Parte posterior do corpo (depois da cloaca) musculosa e desenvolvida, com duas nadadeiras dorsais semelhantes (Fig. 243), nadadeira caudal bem destacada; focinho variando desde arredondado (ex. Rhina e Trygonorrhina, que não ocorrem no Brasil) até alongado (Fig. 243, seta C), podendo possuir a forma de serra (Fig. 244, seta).....

RHINOPRISTIFORMES

2b. Parte posterior do corpo (depois da cloaca) estreitando abruptamente (Figs. 245, seta A e 246, seta A); nadadeiras dorsais, quando presentes, variando de uma a duas (Figs. 245, seta B e 246, seta B); nadadeira caudal presente ou não; focinho quando presente não prolongado, nunca possuindo forma de serra 3 3a. Cauda não apresenta forma de chicote (Fig. 245, seta A); ferrão caudal ausente...

RAJIFORMES

3b. Cauda bastanteafilada, em forma de chicote (Fig. 246, seta A); a maioria das espécies com ferrão caudal (Fig. 246, seta C)...... MYLIOBATIFORMES

\section{ORDEM RHINOPRISTIFORMES}

Com base em estudos moleculares, esta ordem foi designada por Last, Serét e Naylor (2016), o que dificulta buscar caracteres morfológicos externos e de fácil identificação em campo. Neste estudo foram incorporadas aos Rhinopristiformes as (então) ordens Pristiformes (peixes-serra) e Rhinobatiformes (raias-viola e afins), englobando as famílias Pristidae, Rhinobatidae, Trygonorhinidae, Rhinidae e Glauscotegidae. As duas últimas não ocorrem no Brasil. 
Nesse grupo a parte posterior do corpo é desenvolvida e alongada, não se destacando muito do disco, e com duas nadadeiras dorsais bem evidentes (de formato morfologicamente semelhante); nadadeira caudal presente.

\section{Família PRISTIDAE}

Raias de grande porte (atingindo até 7,5 m de CT) e de corpo fusiforme. Apresentam focinho extremamente alongado e achatado, com dentes laterais similares a uma serra. Olhos e espiráculos se posicionam no topo da cabeça. Corpo coberto uniformemente por dentículos dérmicos minúsculos, mas tubérculos são ausentes. Possuem duas nadadeiras dorsais; nadadeira caudal desenvolvida, com ou sem lobo inferior definido. Nadadeiras peitorais curtas, fusionadas à parte posterior da cabeça (em algumas espécies essa característica não é tão evidente), sem atingir a boca. Estas nadadeiras terminam anteriormente ao início das nadadeiras pélvicas. Nadadeiras pélvicas com um lobo simples e moderadamente expandido. Os peixesserra distribuem-se circunglobalmente em águas costeiras, estuários, bocas de rios e águas doces de regiões tropicais e subtropicais. Alguns exemplares foram capturados a $1.340 \mathrm{~km}$ de distância da boca do Rio Amazonas. Preferem tanto substratos arenosos quanto lamosos, dificilmente habitando profundidades maiores que dez m. Frequentemente são capturados por redes ou arrastões em regiões tropicais; sua carne é utilizada para consumo humano, e os dentes das serras, para ornamentação. A superexploração aliada à degradação ambiental conduziu ao declínio da maioria das populações de peixe-serra, e hoje esses peixes são severamente ameaçados de extinção. Os dentes rostrais dos embriões são cobertos por uma membrana, e a serra é flexível, prevenindo a ocorrência de ferimentos na mãe durante o processo do parto. Apesar de os dentes laterais se desenvolverem ao longo da vida dessas raias, não são repostos quando perdidos. As serras funcionam como potente mecanismo de defesa ou servem para capturar suas presas. Para isso, o peixe-serra vasculha a lama e fazendo movimentos laterais dentro do cardume a ser predado. Neste caso, os peixes que ficam presos nos dentes rostrais são retirados quando as raias raspam a serra contra o fundo. No mundo há apenas uma família conhecida, Pristidae, com dois gêneros e sete espécies, mas possivelmente existem outras por descrever.

São conhecidos dois gêneros (Anoxypristis e Pristis) e cinco espécies no mundo, das quais duas delas são encontradas no Brasil (P. pectinata e $P$. pristis).

\section{Gênero Pristis}

As características da família são suficientes para identificação do gênero. No gênero Anoxypristis, sem ocorrência no Atlântico, os dentes da serra não chegam até a sua base (perto da cabeça) e, além disso, o lobo inferior da nadadeira caudal 
é desenvolvido, com comprimento maior do que a metade do comprimento do lobo superior. Já no gênero Pristis, os dentes da serra chegam até a base (perto da cabeça), e o lobo inferior da nadadeira caudal é menos desenvolvido, com comprimento menor do que a metade do comprimento do lobo superior. São conhecidas cerca de seis espécies, porém ainda há a necessidade de revisão taxonômica desse grupo.

\section{Chave para Identificação das Espécies do Gênero Pristis}

1a. Nadadeira caudal sem lobo inferior definido (Fig. 247, seta); origem da primeira nadadeira dorsal na linha de origem da nadadeira pélvica (Fig. 247); rostro (serra) com mais de 23 pares de dentes laterais

Pristis pectinata

1b. Nadadeira caudal com lobo inferior definido (248, seta); origem da primeira nadadeira dorsal anterior à origem da nadadeira pélvica; (Fig. 248); rostro (serra) com até 20 pares de dentes laterais.

Pristis pristis

Pristis pectinata Latham, 1794 (Fig. 249)

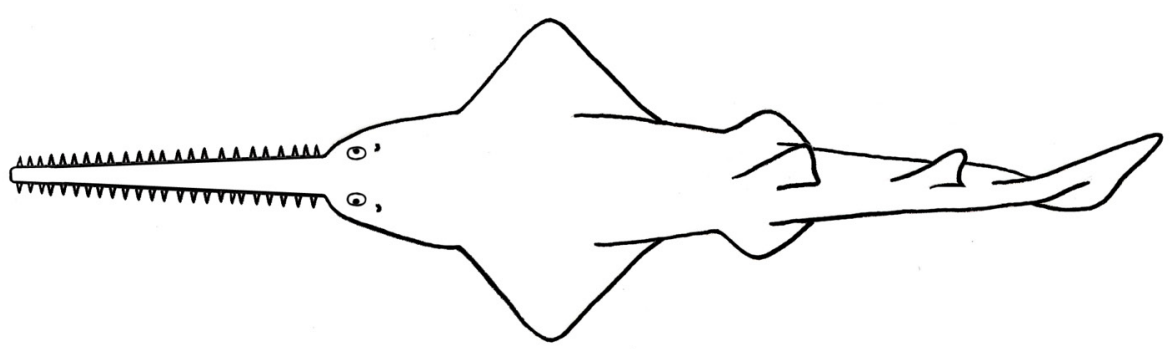

Nomes populares: peixe-serra, espadarte.

Caracteres distintivos: possui, no mínimo, 23 pares de dentes laterais no rostro (serra); cauda sem lobo inferior definido. Coloração do dorso castanha acinzentada a castanha escura; superfície ventral branca a branca acinzentada.

Tamanho: atinge 5,5 $\mathrm{m}$ de CT máximo; rostro serrilhado chega a medir mais de $1 / 4$ do comprimento total. As fêmeas atingem a maturidade sexual com 4,6 m de comprimento; os filhotes nascem com cerca de $60 \mathrm{~cm}$ de CT.

Distribuição, Hábitos e Biologia: espécie registrada desde a Carolina do Norte e Bermudas até o sul da Flórida, expandindo em direção sul através do Golfo do México, Bahamas, costa do Caribe na América Central, e do norte da América do Sul até o norte da Argentina. No Brasil atualmente só é encontrada na região Norte. Trata-se de espécie bentônica que vive ao longo da costa, estuários, lagoas, especialmente em fundos lamosos. Podem penetrar em água doce; seus representantes já foram encontrados em grandes rios como Amazonas e Mississipi. A espécie é vivípara lecitotrófica, produzindo de 15 a 20 embriões por gestação. Alimenta-se de pequenos invertebrados bentônicos e peixes ósseos. 
Observações: espécie considerada extinta para a costa do Rio de Janeiro. Seu limite sul de distribuição foi reduzido, e hoje sua ocorrência no Sudeste e Sul do Brasil é remota.

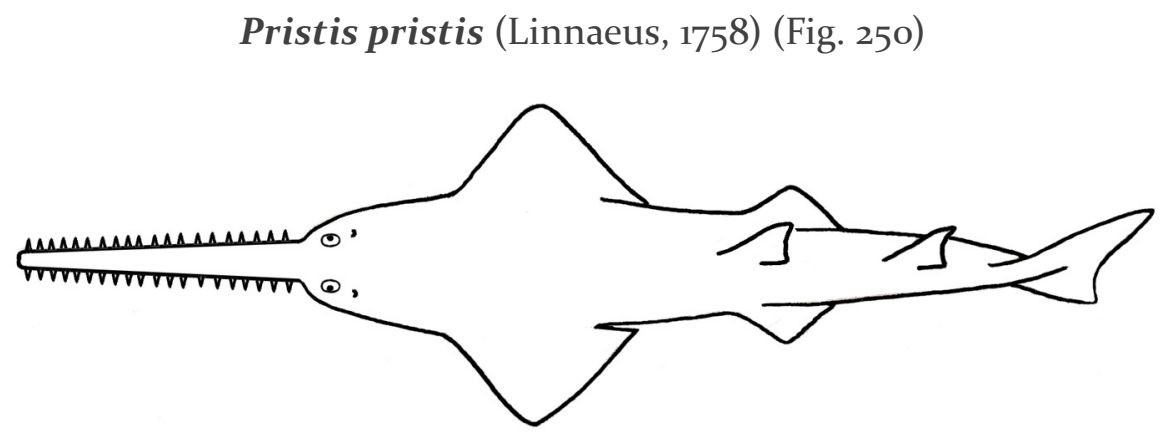

Nomes populares: peixe-serra, espadarte.

Caracteres distintivos: possui até 20 pares de dentes laterais na serra; cauda com lobo inferior bem definido. Coloração da superfície dorsal castanha acinzentada a castanha escura; superfície ventral branca a branca acinzentada.

Tamanho: pode atingir um comprimento de até cerca de 7,5 $\mathrm{m}$ de CT; machos e fêmeas amadurecem entre 2,4 e $3 \mathrm{~m}$ de CT, e os filhotes nascem medindo cerca de 6 o a $76 \mathrm{~cm}$ de CT.

Distribuição, Hábitos e Biologia: registrada desde a Carolina do Norte e Bermuda até sul da Flórida, passando pelo Golfo do México, Bahamas, costa do Caribe na América Central, e norte da América do Sul até São Paulo (Brasil). No Brasil é encontrado no Norte. Também se encontra no Oceano Pacífico Oriental Tropical e no Oceano Atlântico Oriental. Vive em regiões costeiras, estuarinas, lagunares ou de água doce. Quando comparado a P. pectinata, $P$. pristis é provavelmente mais restrito a águas rasas nas vizinhanças imediatas do litoral, lagoas parcialmente fechadas e ambientes semelhantes. Penetra em água salobra e doce, e tende a entrar em grandes rios mais do que $P$. pectinata. Espécie vivípara lecitotrófica, produz de um a 13 filhotes que nascem depois de uma gestação de aproximadamente dez meses. Alimenta-se de pequenos invertebrados bentônicos e peixes ósseos.

Observações: essa espécie é frequentemente identificada como Pristis perotteti e está criticamente ameaçada de extinção (possivelmente já extinta) na costa do Rio de Janeiro. Na casa de um pescador na região de Guaratiba foi encontrada uma serra, identificada como pertencendo a essa espécie. Deve ter sido capturada nos anos 1990, próximo à Barra de Guaratiba (Buckup et al., 2000). Seu limite sul de distribuição foi reduzido, e hoje sua ocorrência no Sudeste e Sul do Brasil é remota.

\section{Família RHINOBATIDAE}

Apresentam primeira nadadeira dorsal originando-se mais próxima à margem posterior das nadadeiras pélvicas do que da extremidade da cauda (Fig. 243, A e B); 
presença de cartilagem rostral que se estende até a extremidade do focinho (Fig. 243, C); focinho sempre em ponta; narinas totalmente separadas da boca; narinas oblíquas em relação ao plano mediano; espiráculos grandes (maiores que o olho). A moldura anterior do espiráculo é bem próxima à órbita (Fig. 251).

A família Rhinobatidae possui três gêneros: Acroteriobatus, Rhinobatos e Pseudobatos. Apenas este último ocorre no Brasil, com duas espécies catalogadas (provavelmente haja uma terceira espécie). Duas espécies são encontradas na costa do Estado do Rio de Janeiro.

\section{Gênero Pseudobatos}

Possuem duas projeções ou cristas dérmicas na margem posterior do espiráculo (Fig. 251); ângulo da extremidade do focinho cerca de $50^{\circ}$. São conhecidas até o presente oito espécies no mundo, porém ainda há necessidade de revisões taxonômicas regionais, principalmente no Oceano Atlântico Sul Ocidental. No Brasil ocorrem Pseudobatos horkelii e P. percellens. A presença de $P$. lentiginosus ainda não foi comprovada, principalmente pela sua inexistência em coleções científicas do Brasil. Esta espécie, até o presente, não ocorre no Brasil.

$\mathrm{O}$ gênero Pseudobatos necessita de uma revisão taxonômica quanto às espécies ocorrentes no Oceano Atlântico Ocidental. Provavelmente um novo arranjo taxonômico deva acontecer. A chave apresentada aqui é considerada provisória.

\section{Chave para Identificação das Espécies do Gênero Pseudobatos}

1a. Com ou sem pontuações ou manchas claras simétricas no dorso (Fig. 252, setas); comprimento da órbita cabe entre 1,4 a 2,6 vezes na distância internasal; fontanela anterior visível na região do focinho; margem anterior da fontanela ocorrendo na metade do comprimento do focinho; largura da boca cabe menos de três vezes na distância pré-oral Pseudobatos percellens 1b. Sem pontuações ou manchas claras simétricas no dorso (coloração uniforme Fig. 253); comprimento da órbita cabe entre 1,10 a 1,5 vezes na distância internasal; fontanela anterior visível na região do focinho; margem anterior da fontanela ocorrendo antes da metade comprimento do focinho; largura da boca cabe mais de três vezes na distância pré-oral.

Pseudobatos horkelii 


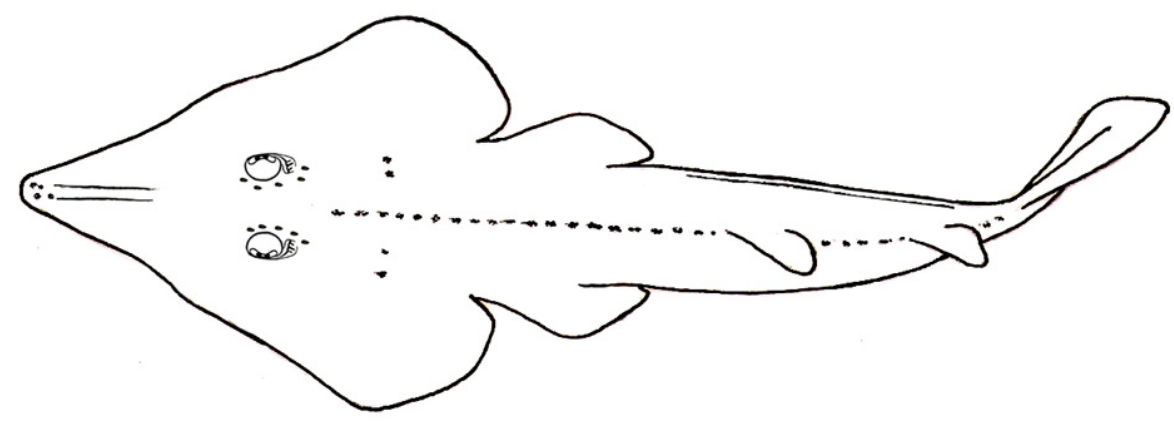

Nomes populares: raia-viola, cação-viola.

Caracteres distintivos: tubérculos em fileira mediana no dorso pouco numerosos (menos de 30) e bem definidos, sendo facilmente contáveis; apresenta fileira de tubérculos entre as nadadeiras dorsais, dois tubérculos de cada lado da cintura escapular (ombro), paralelos à fileira mediana; tubérculos circum-orbitais presentes. Coloração da superfície dorsal cinza oliva ou castanha (chocolate), sem pontuações esbranquiçadas simétricas no dorso; superfície ventral esbranquiçada, exceto pela ponta do focinho que possui uma mancha escura oval destacada. Quando em vida, o rostro é praticamente transparente.

Tamanho: CT máximo de 1,35 m; os machos amadurecem com cerca de $75 \mathrm{~cm}$ de CT, e fêmeas, com cerca de $90 \mathrm{~cm}$ de CT. Nascem medindo entre 22 e $29 \mathrm{~cm}$ de comprimento.

Distribuição, Hábitos e Biologia: distribui-se da Paraíba (Brasil) até a Argentina, com registros duvidosos para o Caribe e também para as Índias Ocidentais. É bentônica, habitando águas costeiras. Vive em profundidades superiores a $20 \mathrm{~m}$ durante a maior parte do ano, porém se aproxima da costa durante a primavera e o verão em busca de águas mais quentes para se reproduzir. Espécie vivípara lecitotrófica, parindo de três a 12 embriões. Alimenta-se de crustáceos, cefalópodos e pequenos peixes.

Observações: estudos recentes indicam drástico declínio de seu estoque no sul do país (95\% em dez anos), indicando que essa espécie está criticamente ameaçada nessa região. Aparentemente mais abundante no sul do Brasil.

Pseudobatos percellens (Walbaum, 1792) (Fig. 255)

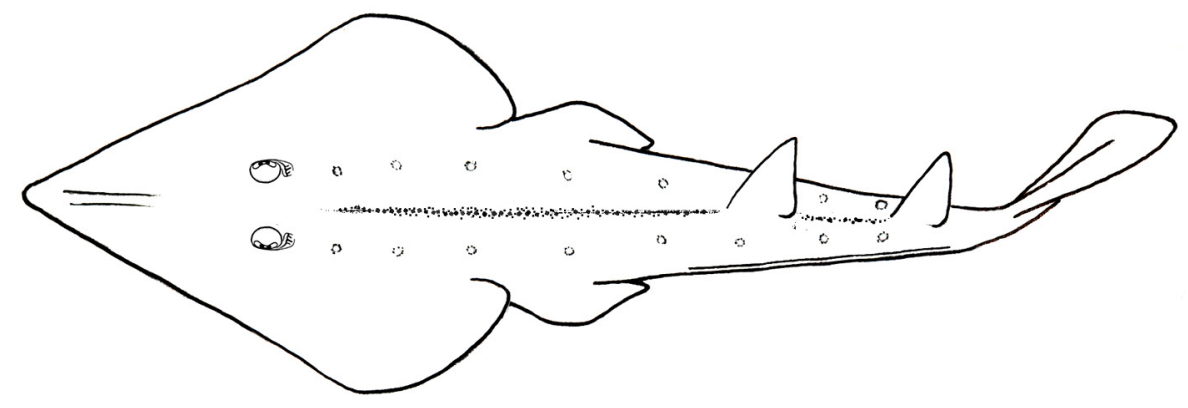


Nomes populares: raia-viola, cação-viola.

Caracteres distintivos: tubérculos numerosos (mais de 70) em fileira mediana no dorso, alguns se sobrepõem aos outros e por isso são de difícil contagem; presença de um a dois tubérculos de cada lado da cintura escapular (ombro); vários tubérculos circundando as órbitas e atrás dos espiráculos. Coloração dorsal castanha clara ou escura uniforme, muitas vezes com pequenas pontuações claras simétricas, principalmente no disco; nesta região do corpo podem exibir manchas escuras transversais pouco evidentes; ventre amarelado. Não possuem mancha escura na extremidade do focinho.

Tamanho: pode atingir pouco mais de um metro de CT; machos amadurecem com cerca de $44 \mathrm{~cm}$, e fêmeas, entre 46 e $50 \mathrm{~cm}$ de CT. Nascem medindo entre 14 e $17 \mathrm{~cm}$ de comprimento.

Distribuição, Hábitos e Biologia: distribuem-se do Panamá, Jamaica, Antilhas e costa norte da América do Sul ao norte da Argentina. Hábitos bentônicos em águas costeiras, atingindo profundidades de até $110 \mathrm{~m}$ aproximadamente. Vivípara lecitotrófica, produz até cinco filhotes por parto. Alimentação constituída de invertebrados e, em menor escala, pequenos peixes ósseos bentônicos.

Observações: Pseudobatos lentiginosus é bastante similar a essa espécie e possui a cartilagem do focinho expandida em forma de espátula, além de manchas espalhadas aleatoriamente no corpo, que são menores e mais numerosas do que em $P$. percellens.

\section{Família TRYGONORHINIDAE}

São raias de porte médio atingindo cerca de 1,5 $\mathrm{m}$ de CT. Focinho variando desde alongado e pontiagudo até curto e rombo. Presença ou ausência de uma crista dérmica na margem posterior do espiráculo (Fig. 256). Presença de uma fileira de tubérculos ao longo da região mediana do dorso. Lobo ventral da nadadeira caudal pouco evidente. Nadadeiras dorsais desenvolvidas, semelhantes em formato e tamanho.

Três gêneros são conhecidos: Aptychotrema, Trygonorrhina e Zapteryx. Os dois primeiros ocorrem na Austrália. As três espécies de Zapteryx ocorrem nas Américas. Zapteryx exasperata (Jordan \& Gilbert 1880) é registrada principalmente da Califórnia (Estados Unidos da América) até o norte do México, no Oceano Pacífico. A espécie Zapteryx xyster Jordan \& Evermann 1896, também do Oceano Pacífico, ocorre do México até o Peru. A única espécie desse gênero que ocorre no Oceano Atlântico é Zapteryx brevirostris (Müller \& Henle, 1841), do Sudeste do Brasil até Argentina.

\section{Gênero Zapteryx}

Caracterizado por possuir apenas uma crista dérmica na margem posterior do espiráculo (Fig. 256) e ângulo da ponta do focinho podendo variar de $85^{\circ}$ a $90^{\circ}$. 


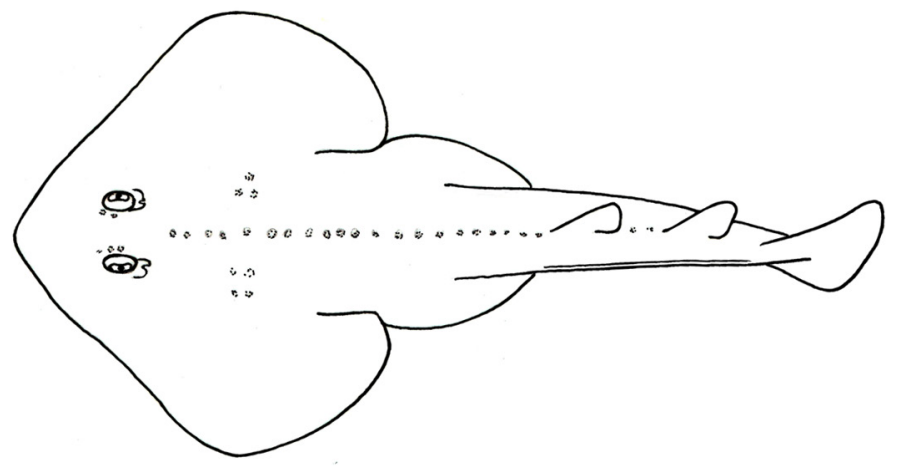

Nomes populares: raia-viola-de-focinho-curto.

Caracteres distintivos: Adicionalmente à fileira bem destacada de tubérculos medianos, apresenta tubérculos esparsamente distribuídos em forma de cones na superfície dorsal e na região escapular; nadadeiras dorsais com margens posteriores maiores que suas bases de implantação. Coloração dorsal castanha, ocasionalmente com leves tons violáceos; ventralmente é esbranquiçada, exceto na borda posterior das nadadeiras peitorais, em que há uma mancha irregular mais escura. Machos adultos apresentam coloração alaranjada na parte ventral do rostro; jovens com barras mais escuras irregulares sobre disco e cauda.

Tamanho: os maiores exemplares têm cerca de $66 \mathrm{~cm}$ de CT; a maturidade sexual ocorre com $42 \mathrm{~cm}$ e 43,7 cm de CT para fêmeas e machos, respectivamente; tamanho ao nascer cerca de 13 a $16 \mathrm{~cm}$ de comprimento.

Distribuição, Hábitos e Biologia: distribui-se desde o Sudeste do Brasil até Mar Del Plata (Argentina). É frequente na costa do Estado do Rio de Janeiro, encontrada em águas costeiras até $60 \mathrm{~m}$ de profundidade. Espécie vivípara lecitotrófica, nascem de dois a oito embriões por parto. Alimenta-se de crustáceos (caranguejos, camarões, anfípodas e isópodas), poliquetas, anfioxos e, ocasionalmente, peixes ósseos.

Observações: no Rio de Janeiro seu estoque não sofre tanta exploração por pesca dirigida, apesar de ser capturada em pescarias artesanais e industriais. Embora não comercializada em grande escala, sua carne é consumida por populações de baixa renda que circula nas colônias de pesca e nos locais de desembarque pesqueiro. $\mathrm{O}$ recente aumento no número de aquários de grande porte no Sudeste e Sul do Brasil incentivou o aumento na captura de exemplares desta espécie, com a finalidade de manutenção em cativeiro, o que pode representar futura ameaça às suas populações.

\section{ORDEM TORPEDINIFORMES}

Seus representantes se caracterizam pela presença de órgãos elétricos (derivados dos músculos branquiais) de contorno com formato de feijão, visíveis na região dorsal e ventral do disco (Figs. 258 e 260); a parte anterior do focinho é 
arredondada ou quase reta; presença de duas nadadeiras dorsais (exceto na família Narkidae, que não ocorre no Brasil); nadadeiras dorsais moderadamente largas e arredondadas; focinho arredondado ou truncado; olhos pequenos, funcionais na maioria das espécies, sendo, porém, rudimentares ou mesmo totalmente cobertos pela pele em algumas espécies; espiráculos localizados próximos aos olhos ou separados por um espaço estreito; margens dos espiráculos lisas ou ornamentadas por papilas ou botões; narinas moderadamente grandes, próximas entre si e da boca; narina com abas nasais formando uma cortina nasal e com amplos sulcos nasorais; corpo espesso e deprimido, sem dentículos; tubérculos ausentes. Podem ser encontrados no Oceano Índico, Mar Mediterrâneo, África (Oceano Oriental), como também no Atlântico Ocidental. Essa ordem possui quatro famílias, 13 gêneros e cerca de 54 espécies. No Brasil ocorrem duas famílias, cinco gêneros e, pelo menos, seis espécies. As duas famílias (Torpedinidae e Narcinidae), cada qual com um gênero e uma espécie, já foram registradas na costa do Estado do Rio de Janeiro.

\section{Chave para Identificação das Famílias da Ordem Torpediniformes}

1a. Margem anterior do disco reta (Fig. 258, seta); primeira nadadeira dorsal maior que a segunda (Fig. 259, setas); origem da primeira nadadeira dorsal anterior à axila da nadadeira pélvica (Fig. 259).

Torpedinidae

1b. Margem anterior do disco convexa (Fig. 26o, seta); primeira nadadeira dorsal do mesmo tamanho que a segunda (Fig. 261, setas); origem da primeira nadadeira dorsal no mesmo nível ou posterior à axila da nadadeira pélvica (Fig. 261). Narcinidae

\section{Família TORPEDINIDAE}

Caracteriza-se pela margem anterior do disco reta; primeira nadadeira dorsal maior que a segunda; altura da segunda nadadeira dorsal contida 1,5 a duas vezes na altura da primeira; nadadeira caudal alta, com altura três vezes maior que a distância entre os espiráculos; origem da primeira nadadeira dorsal anterior à axila da nadadeira pélvica. Essa família é representada no mundo pelos gêneros Torpedo (dez espécies) e Tetronarce (oito espécies). No Brasil ocorre a espécie (Tetronarce puelcha) registrada no na costa do Estado do Rio de Janeiro. É possível que ocorra no Brasil a espécie Tetronarce occidentalis, faltando, porém, confirmação.

\section{Gênero Tetronarce}

Tetronarce difere de Torpedo por possuir as margens do espiráculo lisas (Torpedo possui papilas ou botões na margem do espiráculo). Raias de porte médio, 
com até 1,8 m de CT, que vivem em regiões tropicais até temperadas. Essas raias apresentam distribuição batimétrica ampla, ocorrendo preferencialmente em águas rasas, até cerca de $600 \mathrm{~m}$ de profundidade, no talude continental. Na costa do Estado do Rio de Janeiro há apenas a espécie Tetronarce puelcha, que representa o primeiro registro de ocorrência do gênero no Estado.

Tetronarce puelcha (Lahille, 1926) (Fig. 262)

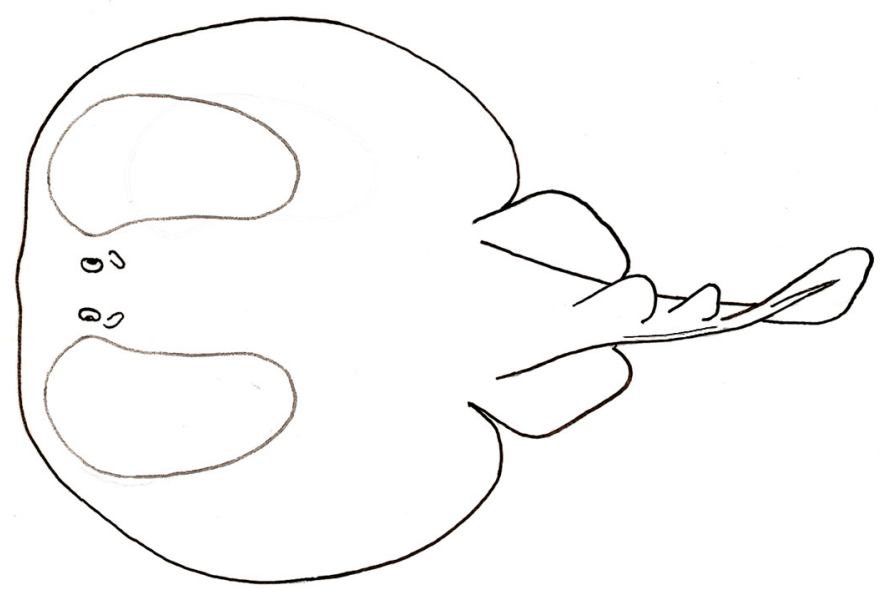

Nome popular: raia-elétrica.

Caracteres distintivos: disco mais largo do que longo; nadadeira caudal em formato subtriangular; pequena crista lateral (na verdade dobras da pele) em cada lado do pedúnculo caudal; distância da extremidade da cauda ao centro da cloaca consideravelmente menor do que a distância da cloaca ao focinho; narinas transversas ou levemente oblíquas em relação ao eixo médio do corpo, posicionadas mais próximas da boca do que da extremidade do focinho, e maiores do que o espaço entre eles; cortina nasal subquadrangular, consideravelmente mais larga do que longa, encobrindo as extremidades externas da abertura nasal, até a arcada superior; boca amplamente protrátil (não verificável em exemplares fixados, pois ficam rijos). Coloração castanha escura uniforme no dorso e clara no ventre; exemplares de pequeno porte com margens do disco enegrecidas.

Tamanho: essa espécie pode atingir 1,5 m de CT.

Distribuição, Hábitos e Biologia: no Brasil tem registros pontuais para a costa dos Estados do Rio de Janeiro, Santa Catarina e Rio Grande do Sul. Muitos padrões biológicos são desconhecidos, mas certamente é vivípara lecitotrófica como os demais Torpediniformes. Sua alimentação também deve ser baseada em invertebrados e pequenos peixes bentônicos. Possivelmente utiliza seus órgãos elétricos para atordoar pequenas presas e para defesa.

Observações: Exemplares coletados no Norte e Nordeste necessitam ter sua identificação ainda confirmada. Possivelmente pertencem à espécie Tetronarce occidentalis (Storer, 1843). 


\section{Família NARCINIDAE}

Margem anterior do disco convexa, arredondada; primeira nadadeira dorsal de tamanho similar ao da segunda; altura da segunda nadadeira dorsal contida uma vez na altura da primeira; nadadeira caudal baixa, com altura duas vezes menor que a distância entre os espiráculos; origem da primeira nadadeira dorsal no mesmo nível ou posterior à axila da nadadeira pélvica. São conhecidos quatro gêneros (todos ocorrendo no Brasil): Benthobatis, Diplobatis, Discopyge e Narcine, sendo que apenas o último tem representantes na costa do Estado do Rio de Janeiro, com uma espécie. O gênero Benthobatis pode ocorrer em águas profundas ao largo do Rio de Janeiro, enquanto Discopyge é mais restrita ao sul. Diplobatis foi registrada na região Norte do Brasil.

\section{Gênero Narcine}

As características da família são suficientes para distinguir o gênero. As raias pertencentes a esse gênero se caracterizam por possuir margem anterior do disco arredondada. São conhecidas pelo menos 18 espécies no mundo. No Brasil existem duas espécies: Narcine bancrofti (Griffith \& Smith, 1834), N. brasiliensis (Olfers, 1831). A primeira ocorre no Nordeste, a segunda, do Nordeste ao Sul brasileiro (além de águas uruguaias e argentinas).

Narcine brasiliensis (Olfers, 1831) (Fig. 263)

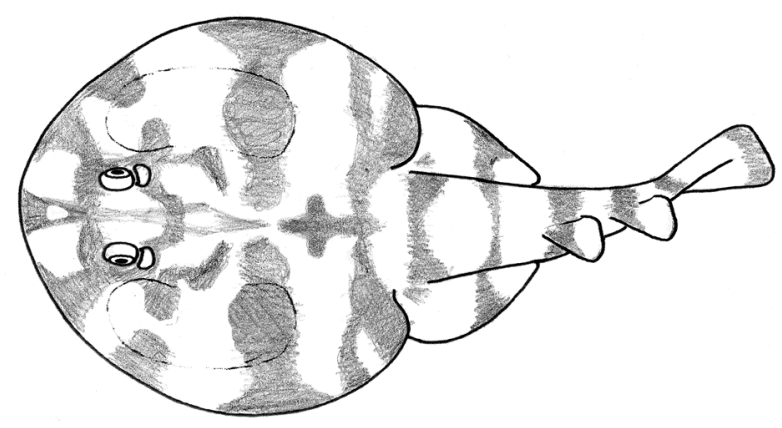

Nomes populares: raia-elétrica, treme-treme.

Caracteres distintivos: focinho em frente aos olhos rígido ao toque; margens dos espiráculos sem papilas ou botões; origem da primeira dorsal sobre ou levemente posterior às bases das pélvicas; espiráculos situados bem atrás dos olhos ou separados por um pequeno espaço, cujo comprimento equivale a aproximadamente $1 / 3$ da distância entre os espiráculos; cortina nasal mais larga do que longa, estendendose à boca. Coloração dorsal predominantemente uniforme, marrom a cinzenta, e normalmente com faixas transversais ou alongadas escuras sobre o disco e região 
caudal. Geralmente esse padrão de coloração é mais evidente em exemplares menores; ventre claro, amarelado, podendo exibir manchas escuras na parte posterior ou lateral do disco.

Tamanho: o maior espécime registrado mediu $49 \mathrm{~cm}$ de CT; dados sobre tamanho da primeira maturidade são escassos, mas possivelmente machos amadurecem com cerca de $25 \mathrm{~cm}$, e fêmeas, com $30 \mathrm{~cm}$ de CT; nasce com cerca de nove a $12 \mathrm{~cm}$ de CT. Distribuição, Hábitos e Biologia: ao longo da costa brasileira, há registros nos estados da Paraíba, do Espírito Santo, Rio de Janeiro, São Paulo (Ubatuba e Cananéia) e Paraná, até o Rio Grande do Sul. Habita águas de até $20 \mathrm{~m}$ de profundidade, em geral sobre fundos de lama. Vivípara lecitotrófica, o número de embriões pode variar de quatro a 15. Alimenta-se de pequenos invertebrados. É capaz de produzir uma corrente elétrica entre 14 e 37 volts.

\section{ORDEM RAJIFORMES}

Caracterizam-se pela cauda moderadamente delgada, visivelmente distinta do disco; dentes numerosos e pequenos, em bandas ao longo das arcadas, podendo ser obtusos nas fêmeas e/ou pontudos nos machos (diferenciando assim machos de fêmeas, em várias espécies dessa ordem de raias); normalmente há duas nadadeiras dorsais, pouco desenvolvidas, próximas entre si e distantes da cauda (em poucas espécies, uma ou nenhuma nadadeira dorsal); nadadeiras pélvicas comumente bilobadas ou raramente com um único lobo lateral. Distribuem-se amplamente em todos os oceanos, do Ártico ao Antártico, desdeáguas rasas costeiras até profundidades abissais (3.00o $\mathrm{m})$; são menos abundantes sobre a plataforma continental, sobre a plataforma de ilhas, em latitudes tropicais, e raras nas proximidades de recifes de corais. As espécies são predominantemente marinhas, mas algumas podem habitar águas salobras. Vivem junto ao substrato. Todas as espécies são ovíparas, produzindo cápsula ovígera membranosa, alongada-retangular, com prolongamento filiforme em cada ângulo, como se fosse uma gavinha. Sua função é a fixação no substrato. Há pesca comercial dessas raias em várias partes do mundo. É um grupo numeroso e complexo taxonomicamente.

Essa ordem é composta por quatro famílias: Rajidae (15 a 16 gêneros), Arhynchobatidae (13 gêneros), Gurgesieliidae (três gêneros) e Anacanthobatidae (cinco gêneros). As três primeiras ocorrem na costa do Estado do Rio de Janeiro. No mundo são catalogadas, até o presente, 296 espécies.

A distinção e caracterização das famílias com base na morfologia externa é muito difícil, devido ao grau de semelhança entre muitos dos seus representantes. Os caracteres mais utilizados para definir as famílias são baseados na morfologia do esqueleto (ex. componentes dos órgãos copuladores, estruturas das cinturas peitorais, topografia craniana e arranjo dos arcos branquiais). 
NOTA: A chave de identificação aqui apresentada para identificar as famílias da ordem Rajiformes não é definitiva. Porém, seguindo os caracteres dos gêneros de cada família, consegue-se chegar a uma fácil identificação até espécie, na região geográfica em questão.

\section{Chave para Identificação das Famílias da Ordem Rajiformes}

1a) Região caudal cabendo de 1,5 a duas vezes no comprimento do corpo (Fig. 264)... Gurgesiellidae

1b) Região caudal cabendo menos de 1,5 a duas vezes no comprimento do corpo (Fig. 265)

2a) Focinho sempre rígido, pela presença de uma cartilagem rostral que pode ser observada por transparência ou toque (Fig. 266, seta), em todos os representantes; tubérculos geralmente desenvolvidos na superfície superior do disco; região caudal portando de um a cinco fileiras de aguilhões bem desenvolvidos, individualizados, ou então muitos aguilhões diminutos, dispostos desorganizadamente, dando à essa região um aspecto uniformemente áspero ao tato

Rajidae

2b) Focinho flexível, em função da ausência de uma cartilagem rostral; observada por transparência ou toque (Fig. 267, seta) (em Psammobatis e Sympterygia), ou focinho podendo ser rígido e suportado por uma cartilagem rostral observada por transparência ou tato (em Bathyraja, Atlantoraja e Rioraja); aguilhões geralmente não desenvolvidos na superfície do disco (exceto em algumas espécies de Psammobatis); aguilhões caudais podem estar ausentes ou presentes: geralmente uma única fileira de aguilhões (até o número máximo de cinco em Psammobatis) Arhynchobatidae

\section{Família GURGESIELLIDAE}

Os caracteres da família são os mesmos do gênero. A família é representada por três gêneros: Fenestraja, Gurgesiella e Cruriraja. Os dois últimos ocorrem no Brasil.

\section{Gênero Gurgesiella}

Caracteriza-se pela nadadeira caudal cabendo cerca de 1,5 a duas no comprimento do corpo; disco mais largo do que comprido; superfície dorsal podendo apresentar tanto pontuações escuras como coloração de fundo clara e uniforme, coberta de diminutas espínulas; região dorsal da cauda com aguilhões pouco 
desenvolvidos; ausência de nadadeiras dorsais (Gurgesiella atlantica) ou presença de uma única nadadeira dorsal (Gurgesiella dorsalifera); região caudal com duas ou mais fileiras de espínulas; região ventral clara, ausência (G. atlantica) ou presença (G. dorsalifera) de poros mucosos negros; clásperes muito longos e estreitos. Das três espécies do mundo, duas ocorrem no Brasil, e uma (Gurgesiella dorsalifera), também na costa do Estado do Rio de Janeiro.

Gurgesiella dorsalifera McEachran \& Compagno, 1980 (Fig. 268)

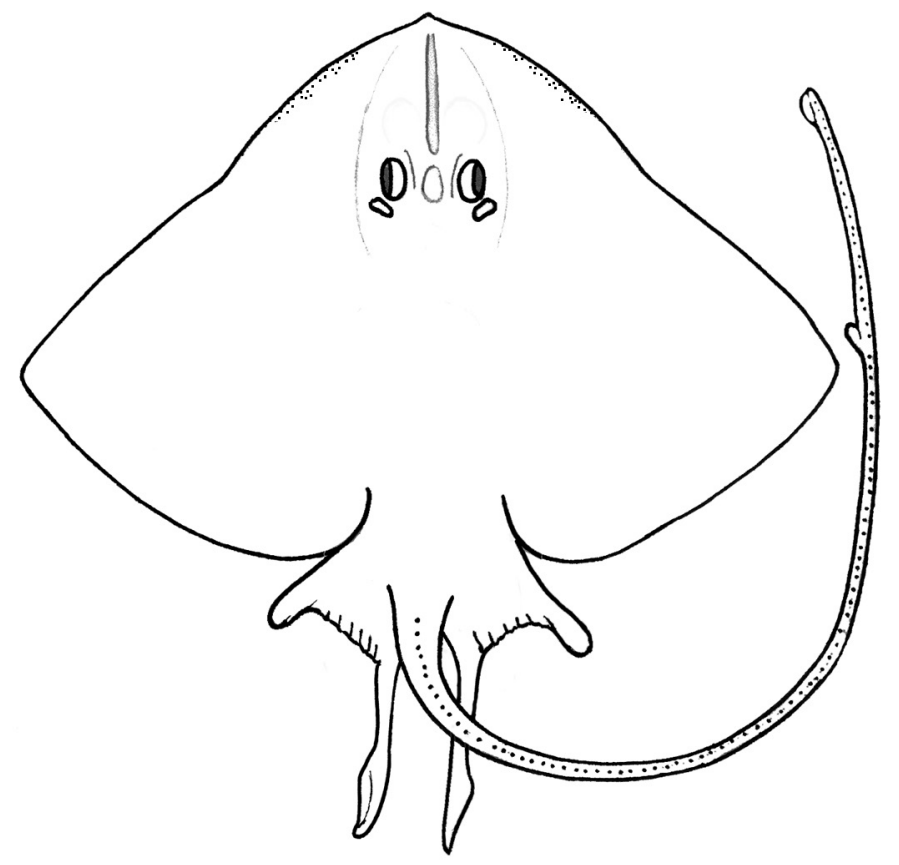

Nome popular: raia-emplastro-de-fundo.

Caracteres distintivos: uma nadadeira dorsal sempre presente e bastante separada da nadadeira caudal; disco rombóide, cabendo cerca de 1,5 vezes no comprimento total; região caudal delgada; cortina nasal lobulada, superfície dorsal do disco áspera devido à presença de espínulas muito diminutas; um maior acúmulo de espínulas mais desenvolvidas é encontrado na região nucal, escapular e médio dorsal do disco; cauda com duas fileiras irregulares de aguilhões diminutos e cônicos; machos com aguilhões malares e cerca de três fileiras de aguilhões alares (num total de 16 a 19 aguilhões). Machos e fêmeas com a superfície ventral do disco lisa. Coloração da superfície dorsal clara ou com manchas escuras arredondadas; os poros sensoriais na superfície dorsal do disco são enegrecidos.

Tamanho: atingem cerca de $30 \mathrm{~cm}$ de LD, e a maturidade sexual de ambos os sexos ocorre em torno de $20 \mathrm{~cm}$; tamanho ao nascer não é conhecido.

Distribuição, Hábitos e Biologia: limitada ao sul do Oceano Atlântico Ocidental, desde o Estado da Bahia até o Estado do Rio Grande do Sul. Ocorre com mais frequência no talude continental, entre profundidades de 470 a $800 \mathrm{~m}$; apresentam também os registros de profundidade de 10-50om; encontrada a temperaturas de 
fundo variando de $4,99^{\circ} \mathrm{C}$ a $8,10^{\circ} \mathrm{C}$. O número de cápsulas ovígeras depositados é desconhecido. Alimenta-se de crustáceos (copépodas, decápodas e misidáceos) e teleósteos.

\section{Família RAJIDAE}

Os caracteres da família são os mesmos dos gêneros. A família é representada por quatro gêneros: Dipturus, Malacoraja, Amblyraja e Rajella. Seus representantes habitam águas profundas, portanto de difícil coleta.

\section{Chave para Identificação dos Gêneros da Família Rajidae}

1a) Focinho proporcionalmente alongado (Fig. 271): comprimento pré-oral cabendo duas ou mais vezes na largura da boca (Fig. 269).....

Dipturus

1b) Focinho proporcionalmente mais curto: comprimento pré-oral cabendo menos de duas vezes na largura da boca (Fig. 270).

. .2

2a) Disco em forma de coração (Fig. 274); região caudal com várias fileiras de aguilhões espalhados desorganizadamente; diminutos aguilhões bem próximos uns dos outros dão à cauda um aspecto uniformemente áspero ao tato (Fig. 274).............Malacoraja 2b) Disco subangular (Figs. 272 e 273); região caudal com uma a cinco fileiras de aguilhões (Figs. 272 e 273)..................................................................................................

3a) Região caudal com três a cinco fileiras de aguilhões na cauda (Fig. 272 - A), aguilhão sem sulco, com base oval ou arredondada (Fig. 272 - B).

Rajella 3b) Região caudal com uma fileira de aguilhões (Fig. 273 - A); pequenos aguilhões com sulcos e com base radiada dispostos na cauda dos adultos (Fig. 273 - B)......Amblyraja

\section{Gênero Dipturus}

É representado por raias de médio a grande porte (atingindo cerca de 2,1 m de $\mathrm{CT}$ ), focinho proporcionalmente longo e rígido (duas ou mais vezes maior que a largura da boca); a pele lisa ou com poucos aguilhões; arranjo triangular de aguilhões na superfície dorsal da região nucal e escapular do disco ausentes ou presentes. Quando presentes estão associados à presença de fileira de aguilhões médio-dorsais; e apresentam de uma a cinco fileiras de aguilhões médio-caudais. Essas raias são encontradas em áreas afastadas da costa, com mais frequência no talude continental. Sua distribuição vertical inclui profundidades de 25 a 1.150 m. São raias de difícil identificação por sua morfologia externa muito conservativa. São conhecidas cerca de 48 espécies, algumas duvidosas e outras tantas ainda por descrever. Para o Brasil 
são assinaladas pelo menos cinco espécies, mas esse grupo, em águas brasileiras, ainda deve ser revisto cuidadosamente.

Dipturus mennii Gomes \& Paragó, 2001 (Fig. 271)

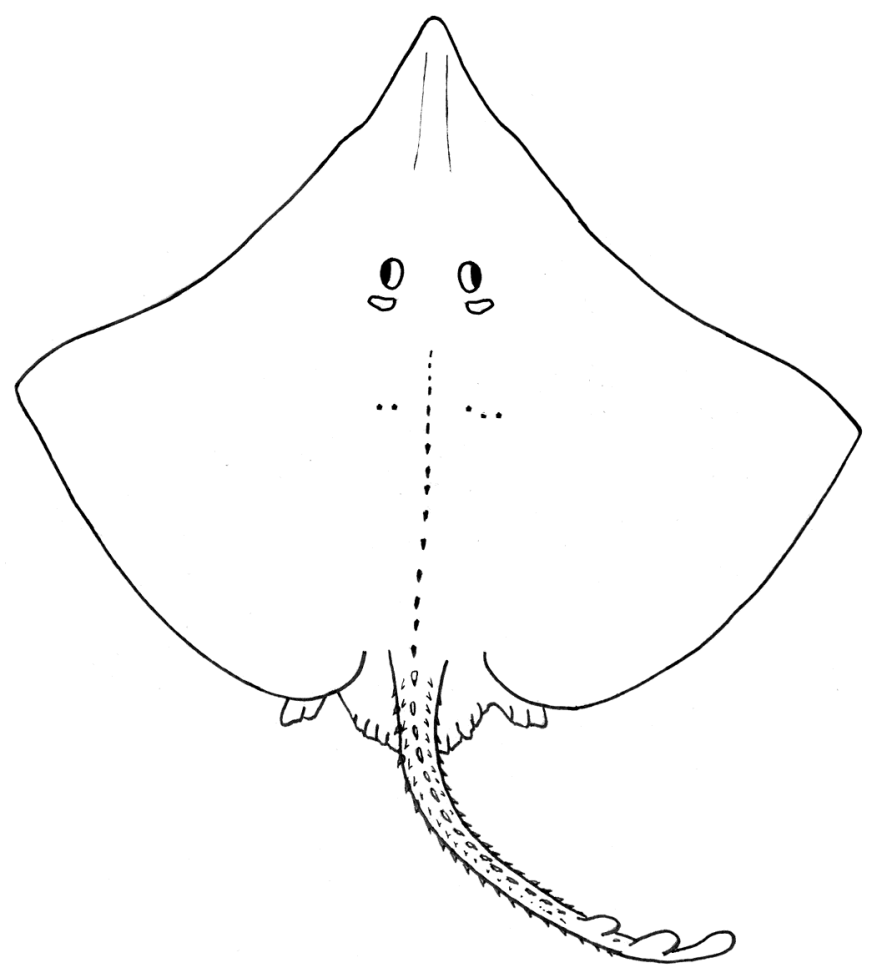

Nome popular: raia-emplastro-bicuda.

Caracteres distintivos: presença de diminutos dentículos espalhados na região interorbital; fileira contínua de aguilhões nucais, médio caudais e caudais; a série mediana de aguilhões médio dorsais, aguilhões nucais, escapulares e escapulares medianos formam um arranjo triangular de aguilhões. Extremidades dorsal e ventral do focinho ásperas, com vários dentículos diminutos; região ventral lisa, com poucos dentículos na região interbranquial. Coloração dorsal e ventral uniformemente castanha, com extremidade ventral das nadadeiras peitorais mais claras.

Tamanho: é uma espécie de grande porte, que pode alcançar pouco mais de 1,6 m de CT e um metro de LD, sem dados sobre tamanho de maturidade e nascimento.

Distribuição, Hábitos e Biologia: registrada desde a fronteira dos Estados do Rio de Janeiro e de São Paulo, até o sul do Rio Grande do Sul. Habita águas da borda da plataforma continental e do talude, entre $133 \mathrm{~m}$ (localidade-tipo) até $513 \mathrm{~m}$ de profundidade.

Observações: essa espécie há muito vem sendo erroneamente identificada como Dipturus trachyderma (Krefft \& Stehmann 1975) devido à aspereza da pele, principalmente na região interorbital. $D$. mennii difere de $D$. trachyderma pela espinulação. Em D. mennii ocorre uma fileira de aguilhões confluentes desde a nuca 
até a origem da primeira nadadeira dorsal (aguilhões somente na região caudal em D. trachyderma). Na série orbital, $D$. mennii possui quatro aguilhões ânteroorbitais, dois a três inter-orbitais e nenhum pós-orbital ( $D$. trachyderma apresenta respectivamente dois aguilhões ântero-orbitais, um interorbital e um pós-orbital). Os machos adultos de $D$. menni possuem três fileiras de aguilhões alares (D. trachyderma tem quatro fileiras). A superfície dorsal dos clásperes é lisa em $D$. mennii (áspera em D. trachyderma).

\section{Gênero Rajella}

Externamente, os representantes do gênero Rajella apresentam clásperes curtos e delgados; disco corporal arredondado de forma rombóide e nadadeiras peitorais arredondadas; focinho truncado e extremamente curto; o comprimento do focinho é nitidamente menor do que o do disco. Dorsalmente, o disco e a cauda são guarnecidos com espínulas e aguilhões. Os agrupamentos de aguilhões nucais, supraescapulares e escapulares freqüentemente formam um arranjo triangular de aguilhões nucaisescapulares. Apresenta ainda aguilhões circum-orbitais, uma fileira de aguilhões médio-dorsais seguidos dos aguilhões médio-caudais e, lateralmente, fileiras de aguilhões látero-caudais dispostos irregularmente. Aguilhões inter-dorsais estão geralmente ausentes. Superfície dorsal escura com manchas e pontuações irregulares, sendo a superfície ventral preponderantemente clara, podendo ser escura. $O$ gênero Rajella é conhecido por 18 espécies e possivelmente algumas outras por descrever. Distribuição conhecida na África do Sul, norte do Oceano Índico, Oceano Pacífico Oriental e todo o Oceano Atlântico Ocidental; encontradas no talude continental até $2.000 \mathrm{~m}$ de profundidade. No Brasil há pelo menos três espécies: $R$. fuliginea (Bigelow \& Schroeder 1954)., R. purpuriventralis (Bigelow \& Schroeder 1962), ambas com identificação incerta e $R$. sadowskii, sendo esta última registrada na costa do Estado do Rio de Janeiro. 


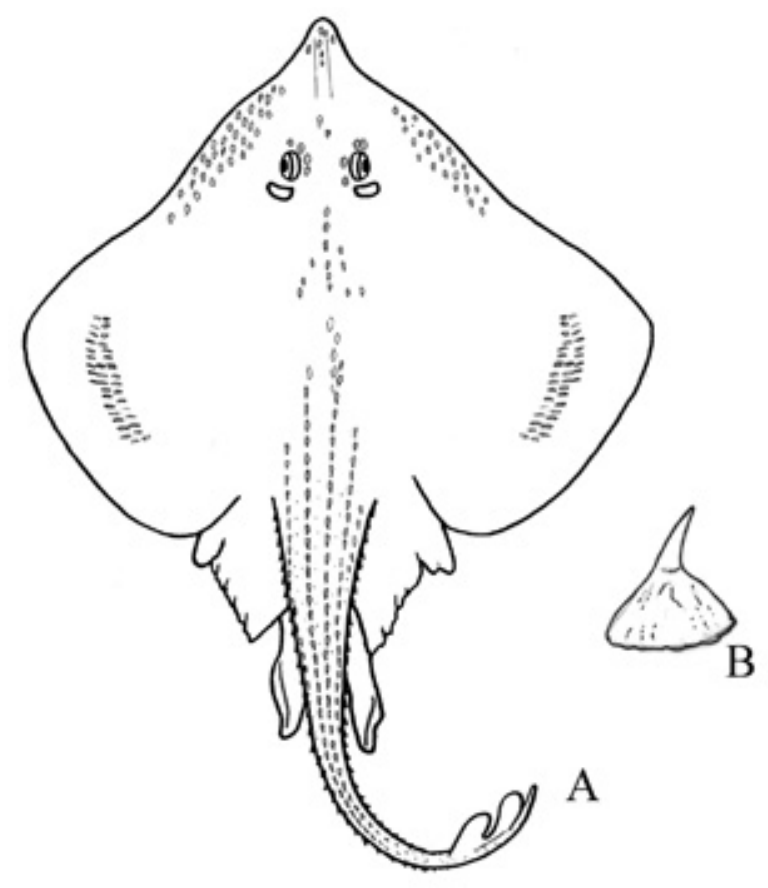

Nome popular: raia-emplastro-cinzenta.

Caracteres distintivos: o formato do disco é arredondado nos jovens, e triangular nos adultos. Nadadeiras dorsais muito próximas, fusionadas nas bases e localizadas na extremidade da cauda. Superfície dorsal intensamente recoberta por espínulas (em juvenis), se tornando levemente recoberta por espínulas (em adultos), com a superfície ventral do corpo lisa. A série mediana de aguilhões mediodorsais, aguilhões nucais, escapulares e escapulares medianos formam um arranjo triangular de aguilhões, com base arredondada ou oval. A disposição dos aguilhões é a seguinte: de um a três pré-orbitais, de um a dois pós-orbitais, de dois a quatro nucais, de um a dois supra-escapulares e um escapular de cada lado.

Coloração: superfície ventral do disco mais escura do que a dorsal (juvenis). Exemplares recém capturados apresentam dorso violeta acinzentado com uma pontuação negra nas peitorais, com nadadeiras dorsais e caudal enegrecidas.

Tamanho: O maior macho registrado mediu 54,2 cm de LD e o menor 22,7 cm de LD. A menor fêmea mediu 15,2 cm (embrião) e a maior 62,9 cm de LD.

Distribuição, Hábitos e Biologia: encontrada em águas brasileiras, entre o Estado do Rio de Janeiro e do Rio Grande do Sul, no talude continental (80o e 1360 $\mathrm{m}$ de profundidade), com temperaturas entre $3^{\circ} \mathrm{C}$ e $5^{\circ} \mathrm{C}$. Recentemente também foi registrada no Chile. No Rio de Janeiro, essa espécie foi capturada a $800 \mathrm{~m}$ de profundidade, próximo a Cabo Frio ( $22^{\circ} 30^{\prime} \mathrm{S}, 40^{\circ} 7^{\prime} \mathrm{W}$ ) e $1360 \mathrm{~m}$ na Bacia de Campos. Sua Biologia é desconhecida, mas a reprodução é ovípara. Produzem cápsulas ovígeras marrom-oliva, com textura estriada longitudinalmente. Alimenta-se, possivelmente, de pequenos invertebrados bentônicos. No Estado do Rio de Janeiro foi capturada em fundos com fauna de corais, gorgônias e esponjas tubulares. 


\section{Gênero Amblyraja}

Cerca de dez espécies conhecidas que habitam águas profundas. Região caudal munida de uma fileira de aguilhões com sulcos e com base radiada. A coloração é geralmente escura.

Amblyraja frerichsi (Krefft, 1968) (Fig. 273)

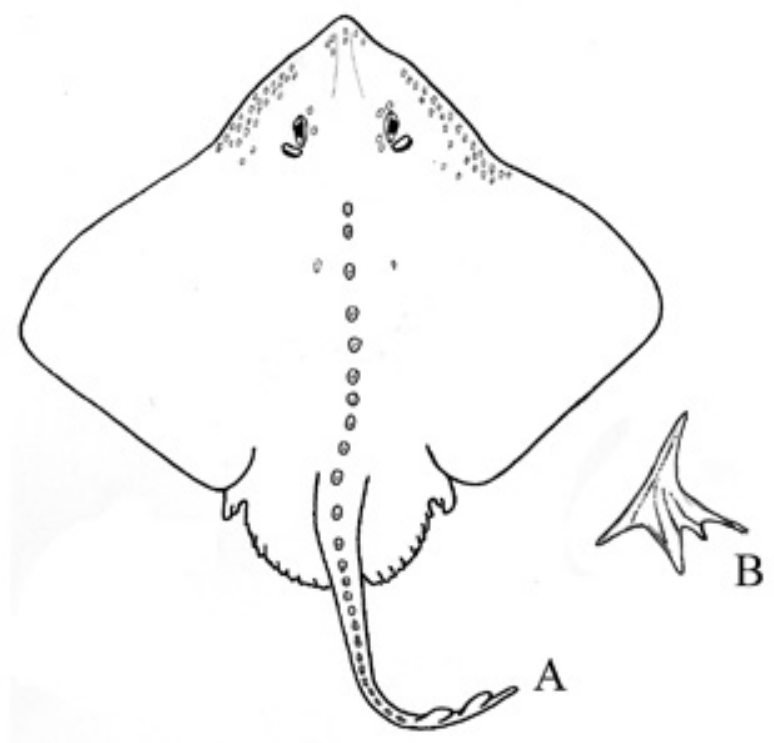

Nome popular: desconhecido

Caracteres distintivos: focinho de aspecto rômbico, com nadadeiras peitorais destacando-se do disco e com extremidades arredondadas. A série mediana de aguilhões mediodorsais, nucais, escapulares e escapulares medianos formam um arranjo triangular de aguilhões. A série mediana de aguilhões mediodorsais varia de 12 a 26, terminando na frente da primeira nadadeira dorsal. Os aguilhões possuem sulcos e base radiada. Tanto nos indivíduos juvenis quanto nos adultos, a superfície dorsal do disco é coberta com fortes aguilhões, principalmente no ápice do focinho e nas margens anteriores das nadadeiras peitorais. Nadadeira caudal presente. A cloaca se localiza mais próxima da cauda do que da ponta focinho nas fêmeas adultas. Nos juvenis, a cloaca está mais próxima da ponta do focinho. Coloração cinza escura ou marrom escuro na superfície dorsal e ventral. Entretanto, as áreas próximas às narinas, boca e cloaca são esbranquiçadas.

Tamanho: Alcançam até $910 \mathrm{~mm}$ de CT; juvenis mediram de 330 a $516 \mathrm{~mm}$ de CT. Nascem em torno de $220 \mathrm{~mm}$ de CT de comprimento.

Distribuição, Hábitos e Biologia: três exemplares dessa espécie foram capturados, (uma fêmea, um macho adulto e um juvenil). Foram obtidos através de arrasto de captura do camarão, a uma profundidade de 700 a $800 \mathrm{~m}$, no talude inferior da plataforma continental brasileira, entre Cabo Frio (RJ) até Ilha de São Sebastião (Ilha Bela, SP) próximo à coordenada $24^{\circ}$ oı'S, entre outubro e novembro de 2004 . O outro 
exemplar (juvenil) foi coletado na fronteira com o Uruguai, $33^{\circ} 50^{\prime} \mathrm{S}$, entre 600 e 1.000 $\mathrm{m}$ de profundidade, dentro de armadilha para a captura do caranguejo-vermelho Chaceon notialis Manning \& Holthuis, 1989 (Família Geryonidae).

Observações: no presente estudo registramos a primeira ocorrência de Amblyraja frerichsi (Krefft, 1968) em águas brasileiras (antes só conhecida em águas chilenas, argentinas e uruguaias). Trata-se de uma espécie rara com poucos indivíduos conhecidos. Esses exemplares estão depositados nas coleções ictiológicas da UERJ e do MZUSP.

\section{Gênero Malacoraja}

O gênero é definido por não apresentar qualquer aguilhão sobre a cauda ou disco, na região posterior à cintura peitoral. A cauda, com exceção de uma estreita banda longitudinal, é igualmente ornamentada com espínulas delicadas. O focinho é curto e levemente achatado. As espécies conhecidas habitam desde águas rasas, aos $50 \mathrm{~m}$, até águas profundas, ultrapassando $2.000 \mathrm{~m}$ de profundidade. Existem quatro espécies no mundo, sendo uma delas (Malacoraja obscura), a única representante no Brasil, registrada também na costa do Estado do Rio de Janeiro.

Malacoraja obscura Carvalho, Gomes \& Gadig 2005 (Fig. 274)

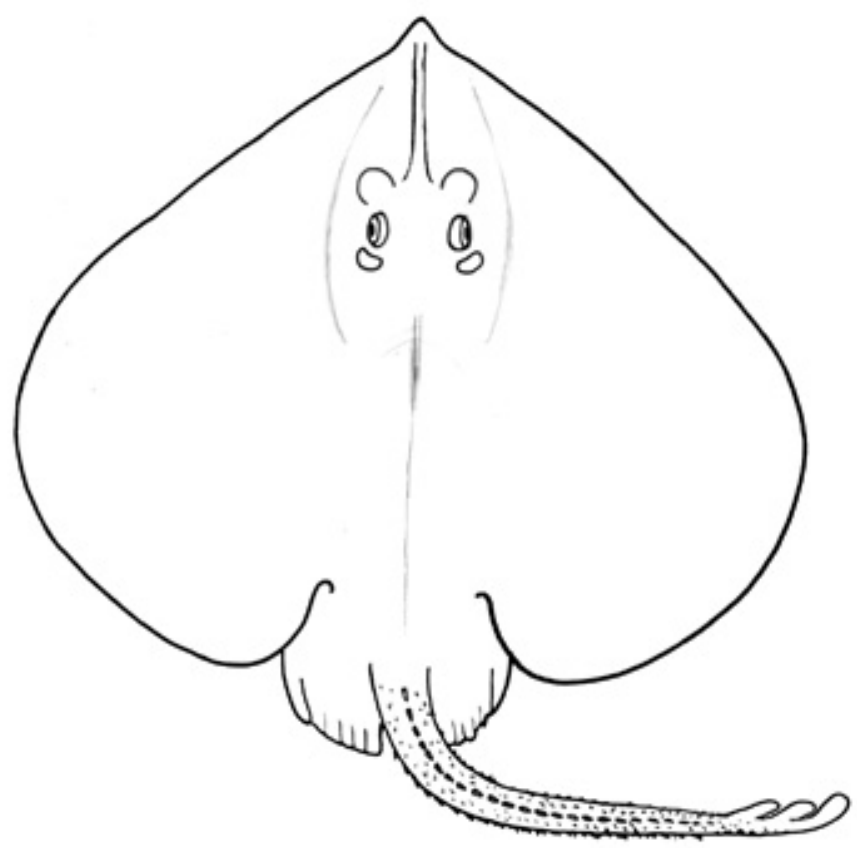

Nome popular: raia-emplastro-escura.

Caracteres distintivos: apresenta uma fileira irregular de espinhos ao longo da superfície dorsal mediana da cauda que é persistente em espécimes maiores, o 
restante da cauda com diminutas espínulas, iguais em tamanho; superfície ventral lisa; ausência de espinhos escapulares em indivíduos maiores, região desprovida de dentículos pequenos na base ventral da cauda (estendendo somente até a margem distal da nadadeira pélvica). Coloração dorsal do disco e das pélvicas com muitas manchas brancas pequenas e desbotadas; manchas esbranquiçadas circulares, aproximadamente do diâmetro da pupila da raia, espalhados pelo dorso; a coloração ventral do disco uniformemente castanho escuro.

Tamanho: o maior exemplar conhecido é uma fêmea de $68 \mathrm{~cm}$ de CT que, de acordo com o tamanho das outras espécies de Malacoraja, pode ser considerado um exemplar adulto. O menor exemplar capturado dessa espécie é um macho, medindo 25,1 cm de CT. Um indivíduo macho de $51 \mathrm{~cm}$ ainda é juvenil, uma vez que os clásperes não estão desenvolvidos.

Distribuição, Hábitos e Biologia: proveniente do talude continental do Sudeste brasileiro dos Estados do Espírito Santo e Rio de Janeiro, em profundidades de 811 a 1,105 m. A espécie é conhecida apenas pelo material-tipo. A biologia dessas raias é desconhecida, mas aspectos reprodutivos possivelmente se assemelham aos demais Rajidae, com reprodução por oviparidade. Possivelmente se alimenta de invertebrados bentônicos.

Observações: essa espécie, descrita no Brasil, corresponde ao primeiro registro de ocorrência do gênero Malacoraja no Atlântico Sul ocidental e, consequentemente, para águas brasileiras.

\section{Família ARHYNCHOBATIDAE}

A família é representada por cinco gêneros: Psammobatis, Sympterygia, Rioraja, Atlantoraja e Bathyraja. Exceto Bathyraja cujos representantes habitam águas profundas do talude continental e zonas abissais, os outros representantes da família são encontrados em águas rasas da plataforma continental.

\section{Chave para Identificação dos Gêneros da Família Arhynchobatidae}

1a) Ponta do focinho flexível, cartilagem rostral não observada por transparência ou tato 2

1b) Ponta do focinho rígida, suportada pela cartilagem rostral desenvolvida, que pode ser observada por transparência ou tato.

2a) Extremidade do focinho com filamento delgado e flexível (Fig. 275, seta A); presença de um arranjo triangular de aguilhões na superfície dorsal da região nucal e escapular do disco (Fig. 275, seta B); região caudal com três a cinco fileiras longitudinais de aguilhões; margem posterior das nadadeiras pélvicas profundamente entalhadas (Fig. 275, seta C)

Psammobatis 
2b) Extremidade do focinho sem filamento delgado e flexível (Fig. 276, seta A); ausência de um arranjo triangular de aguilhões na superfície dorsal da região nucal e escapular do disco (Fig. 276, seta B); região caudal com uma única fileira longitudinal de aguilhões; margem posterior das nadadeiras pélvicas sem entalhe (Fig. 276, seta C) Sympterygia

3a) Presença de mancha negra no ápice ventral do focinho (Fig. 277, seta A); nadadeira caudal ausente ou rudimentar; aba nasal quadrangular, narina falciforme (Fig. 277, seta B); superfície ventral do disco de cor clara Rioraja 3b) Ausência de mancha negra no ápice ventral do focinho (Fig. 278, seta A); nadadeira caudal presente; aba nasal arredondada; narina arredondada (Fig. 278, seta B); superfície ventral do disco escura

4a) Superfície dorsal do disco de coloração variada (nunca uniformemente escura), apresentando um par de ocelos ou inúmeras pontuações escuras; superfície ventral do disco escurecida sobre a região das fendas branquiais e narinas

Atlantoraja

4b. Superfície dorsal do disco uniformemente escura (variando do castanho escuro a negro); superfície ventral do disco uniformemente escura

Bathyraja

\section{Gênero Atlantoraja}

Esse gênero apresenta de dois a três aguilhões inter-dorsais e região ventral do disco escura nos adultos, com um grande número de poros de muco de coloração escura e de formato alongado. A coloração da superfície dorsal do disco é variada (mas nunca uniformemente escura), podendo apresentar um par de ocelos ou pontuações escuras; vente claro, sem mancha negra na extremidade do focinho e com pontuações negras associadas aos poros sensoriais. Superfície dorsal varia desde lisa até áspera. As raias do gênero Atlantoraja possuem hábitos costeiros e de talude, desde águas relativamente rasas até cerca de 500 metros de profundidade. As três espécies conhecidas A. platana, A. cyclophora e A. castelnaui são restritas ao Atlântico Sul ocidental, desde a costa do Estado do Rio de Janeiro até a Argentina.

\section{Chave para Identificação das Espécies do Gênero Atlantoraja}

1a. Ocelos dorsais ausentes no centro da nadadeira peitoral (Fig. 279, seta); superfície dorsal do corpo com pontuações arredondadas escuras distribuídas de forma regular; adultos com a superfície dorsal do corpo extremamente áspera

Atlantoraja castelnaui

1b. Ocelos dorsais presentes no centro da nadadeira peitoral (Fig. 28o, seta); superfície dorsal do corpo sem pontuações arredondadas distribuídas de forma regular; adultos 
com a superfície dorsal lisa, com espínulas eventualmente encontradas na região interorbital

2a. Ocelo dorsal escuro com centro claro, bem definido com dois anéis concêntricos, que podem ser incompletos (Fig. 281, seta)

Atlantoraja cyclophora

2b. Ocelo dorsal com uma ou duas manchas escuras arredondadas, pouco distintas ou ausente nos adultos (Fig. 282, seta).

Atlantoraja platana

\section{Atlantoraja castelnaui (Ribeiro, 1907) (Fig. 283)}

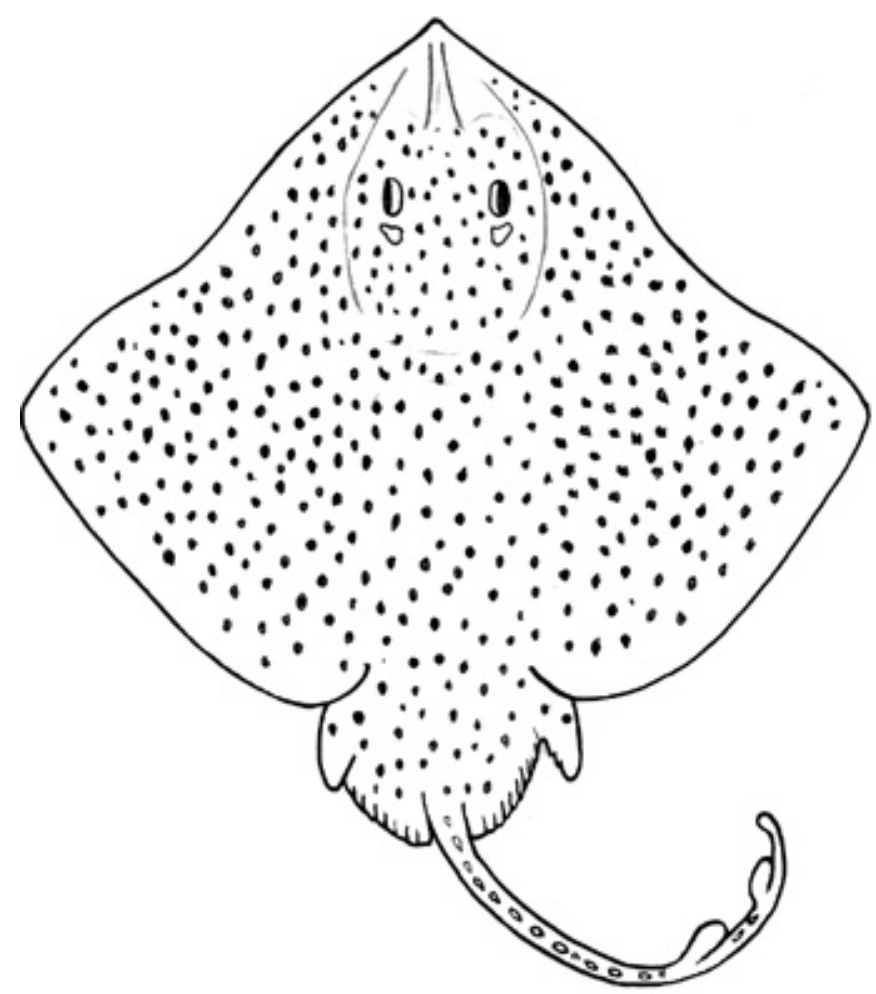

Nomes populares: raia-chita, raia-emplastro.

Caracteres distintivos: os juvenis apresentam superfície dorsal do corpo lisa, sem dentículos dérmicos; subadultos e adultos adquirem, com o crescimento, dentículos que tornam a superfície dorsal áspera. Nos indivíduos subadultos, o dorso tornase áspero até a região caudal. Sobre a região médio-dorsal da cauda, em juvenis e subadultos, foram observados 13 a 22 aguilhões e dois a três aguilhões inter-dorsais. Nadadeira caudal pode ser vestigial em formas juvenis, ou ausente nos recém-natos. Coloração dorsal do disco é escura ou parda, coberta por numerosas pontuações negras pequenas e quase circulares, distribuídas regularmente (em certos casos simetricamente); nos recém-nascidos, algumas pontuações se apresentam coalescidas, formando o desenho de três maculas no dorso do disco. Em indivíduos maiores, o contorno dessas máculas vai desaparecendo, enquanto as pontuações negras permanecem simetricamente distribuídas. Nos subadultos e adultos esta simetria desaparece; as pontuações são distribuídas de forma regular. Nos juvenis, seis a sete selas escuras são localizadas na cauda. 
Tamanho: atinge até 1,4 $\mathrm{m}$ de CT, com machos amadurecendo entre 90 e $95 \mathrm{~cm}$, e fêmeas entre 1,1 e 1,15 $\mathrm{m}$ de CT.

Distribuição, Hábitos e Biologia: a espécie ocorre na costa do Estado do Rio de Janeiro à Argentina, sobre a plataforma continental, desde dez até $500 \mathrm{~m}$. Jovens e fêmeas têm preferência por águas mais costeiras. Os peixes ósseos constituem os principais itens da dieta dessa espécie.

Observações: um registro na costa do Estado do Espírito Santo (mais ao norte de sua área conhecida de distribuição), não foi confirmado. Talvez a espécie menos conhecida do gênero, sob o ponto de vista biológico.

\section{Atlantoraja platana (Günther, 1880) (Fig. 284)}

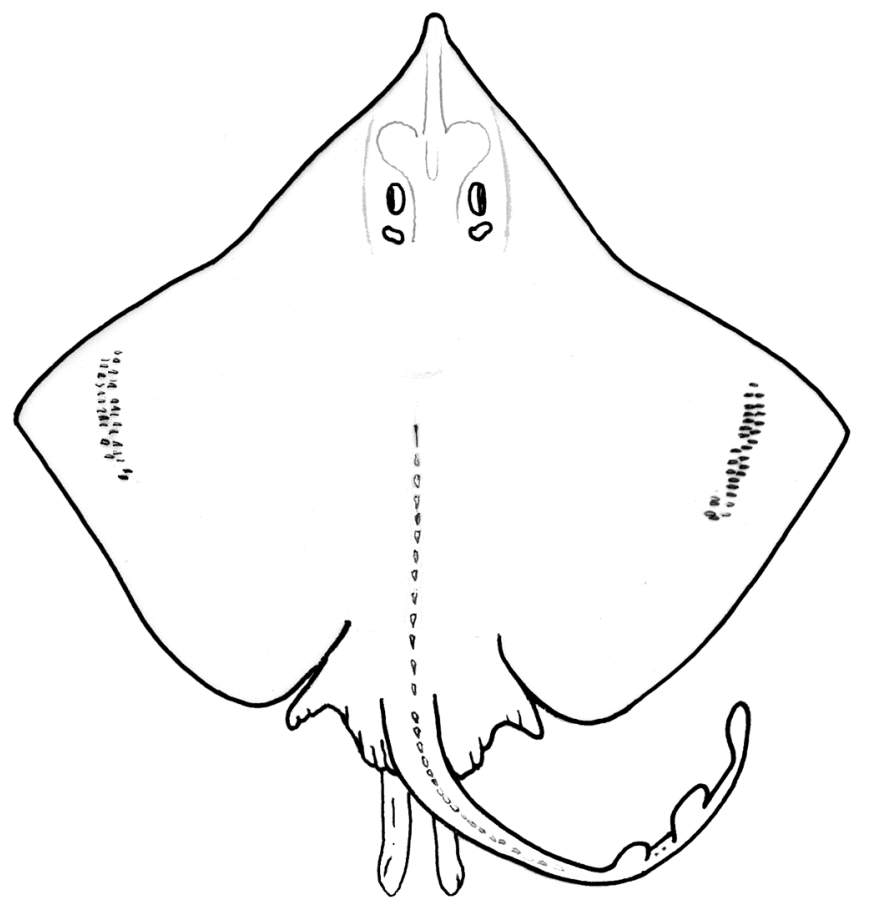

Nome popular: raia-emplastro.

Caracteres distintivos: disco sem aguilhões; presença de espínulas desenvolvidas na região interorbital em adultos; pedúnculo caudal concentra a maior parte da distribuição de aguilhões; uma única fileira de 11 a 13 aguilhões médio-caudais e de dois a três aguilhões interdorsais. Coloração dorsal castanha e ventral com fundo escuro e aberturas de muco de cor negra no ventre; ocelo dorsal com uma ou duas manchas escuras arredondadas pouco distintas nos jovens. Nos adultos essas manchas tornam-se quase imperceptíveis. Nos jovens, a região caudal possui de seis a sete selas que desaparecem nos adultos.

Tamanho: cresce até cerca de um m de CT; maturação sexual em machos com cerca de $62 \mathrm{~cm}$ de comprimento, e em fêmeas, cerca de $75 \mathrm{~cm}$ de CT.

Distribuição, Hábitos e Biologia: ocorre do Rio de Janeiro até o sul de Mar del Plata (Argentina), em profundidades de dez a $300 \mathrm{~m}$, com a maioria dos registros até 
cerca de 100 m (é a espécie de Atlantoraja que habita águas menos profundas). Dieta composta de moluscos (cefalópodes e lulas), crustáceos (camarões) e peixes ósseos.

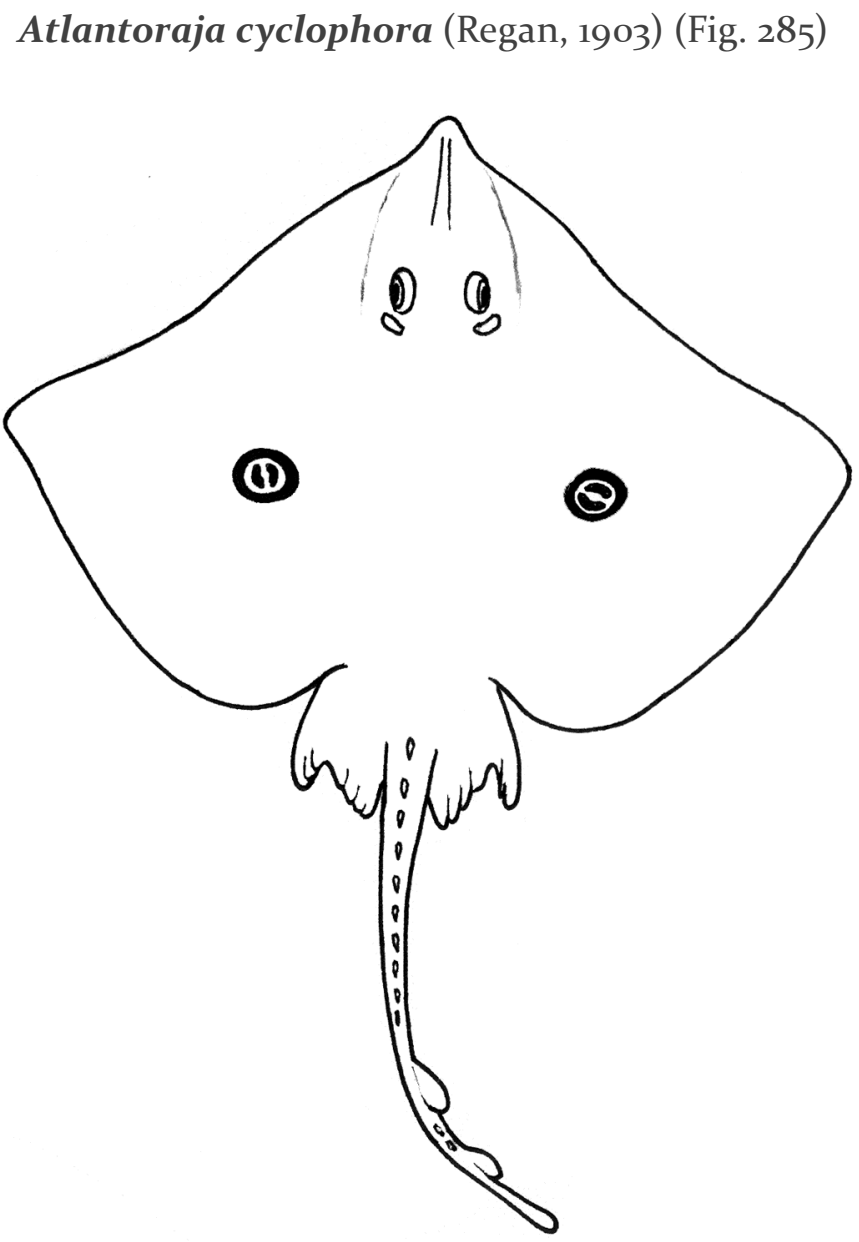

Nomes populares: raia-santa; raia-emplastro.

Caracteres distintivos: ocelo dorsal com centro claro, bem definido, com um ou dois anéis escuros concêntricos. Esses anéis são diagnósticos, porém não chegam a formar um padrão, já que ocorrem variações individuais. Nos juvenis, existem seis a sete selas escuras ao longo do pedúnculo caudal. Existe uma única fileira de dez a 15 aguilhões médio-caudais e dois a três aguilhões inter-dorsais.

Tamanho: atinge até $61 \mathrm{~cm}$ de comprimento total; machos maduros com cerca de 49 $\mathrm{cm}$ e fêmeas medindo $50 \mathrm{~cm}$.

Distribuição, Hábitos e Biologia: ocorre do Rio de Janeiro até sul de Mar del Plata, Argentina; encontrada entre 26 e $500 \mathrm{~m}$ de profundidade (é a espécie do gênero que atinge águas mais profundas). A maior concentração populacional de $A$. cyclophora no sul do Brasil ocorre em profundidades abaixo de $50 \mathrm{~m}$. A dieta principal é composta de crustáceos. 


\section{Gênero Rioraja}

É caracterizado por apresentar aba nasal falcada; nadadeira caudal ausente; geralmente um aguilhão interdorsal. Superfície ventral do disco clara, com poucas pontuações negras; ápice do focinho, na região ventral, com uma mancha negra. Rioraja é um gênero monotípico, representado por Rioraja agassizi, espécie do Oceano Atlântico Sul ocidental, desde o Rio de Janeiro até a Argentina.

Rioraja agassizi (Müller \& Henle, 1841) (Fig. 286)

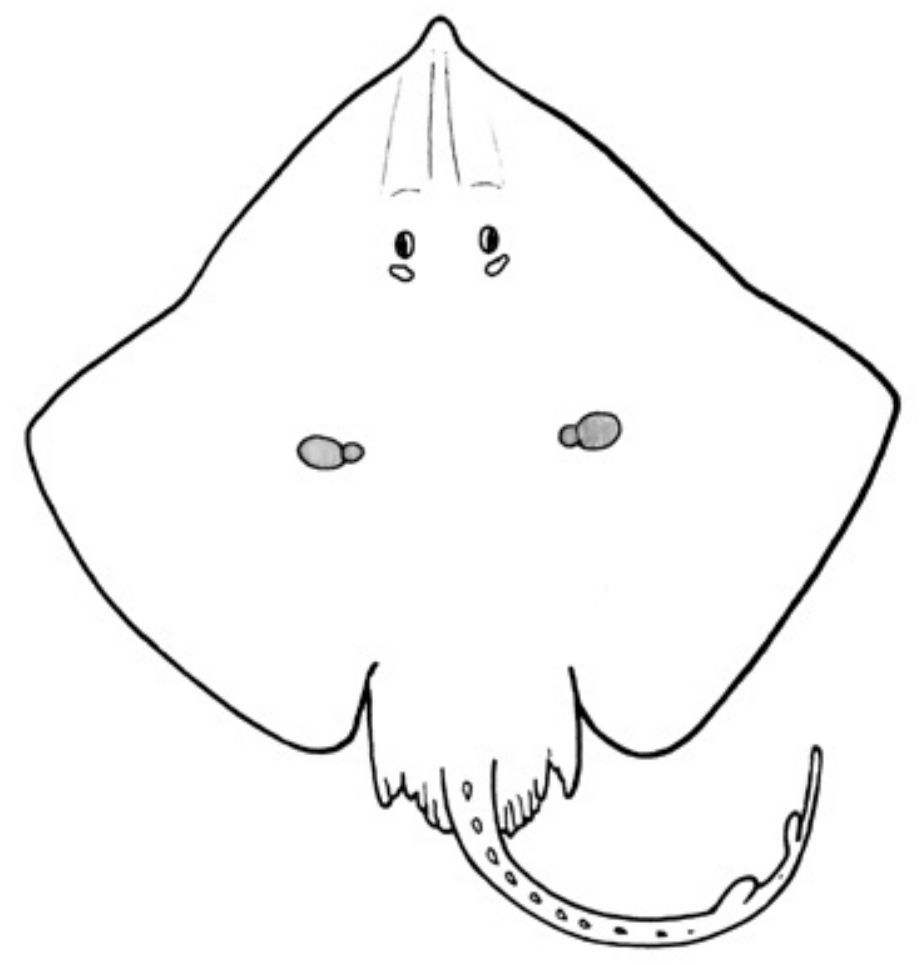

Nome popular: raia-santa.

Caracteres distintivos: caracteriza-se pela cortina nasal com formato quadrangular, extremidade ventral do focinho com uma mancha negra, a aba nasal falcada ou pontiaguda. Superfície dorsal do disco lisa, sem dentículos dérmicos e com uma fileira de aguilhões médio-caudais; um aguilhão interdorsal; nos exemplares juvenis, os aguilhões médio-caudais estão restritos ao pedúnculo caudal, variando de nove a 12. Nos adultos, a variação dos aguilhões médio-caudais é de nove a 13 . Coloração geralmente é castanha clara dorsalmente e esbranquiçada ventralmente; foram encontrados alguns exemplares com uma série de ocelos brancos e simétricos dorsalmente; coloração ventral predominantemente clara, sendo que exemplares com cerca de dez cm não apresentam pontuações negras; a região caudal nos juvenis apresenta de sete a oito selas escuras, dependendo da fusão das últimas selas.

Tamanho: tamanho máximo em torno de $50 \mathrm{~cm}$ de comprimento, com de maturidade iniciando por volta dos $40 \mathrm{~cm}$, para ambos os sexos. 
Distribuição, Hábitos e Biologia: essa espécie é endêmica das águas litorâneas do sul do Oceano Atlântico Ocidental, ocorrendo no Brasil (plataformas Sul e Sudeste), Uruguai e norte da Argentina. Tem preferência por águas temperadas. São costeiras, habitando a plataforma continental; distribuição batimétrica inferior a 120 $m$ de profundidade. O dimorfismo sexual fica evidenciado em indivíduos machos, pela alteração da morfologia da cabeça, boca e dentes, assim como na presença de aguilhões alares. O número de aguilhões caudais é maior nas fêmeas (23) do que nos machos (19). Dieta composta de crustáceos, poliquetas e pequenos peixes ósseos. Essa espécie é aproveitada no desembarque pesqueiro, mas somente os exemplares de maior porte; os menores são normalmente descartados.

Observações: a citação de um exemplar de Rioraja agassizi no arquipélago de Fernando de Noronha representaria o registro mais ao norte da espécie. A identificação da espécie foi confirmada, mas a procedência é duvidosa. Este exemplar encontrase no Museu Nacional de História Natural de Paris. Possivelmente é a espécie de Rajidae mais conhecida sob o ponto de vista biológico, na plataforma do Sudeste e Sul do Brasil.

\section{Gênero Psammobatis}

Caracteriza-se por possuir focinho flexível (não sustentado por cartilagem rostral, o que pode ser observado por transparência), e sua extremidade exibe um filamento curto, delgado e flexível; a região caudal tem várias séries de aguilhões; e a margem posterior da nadadeira pélvica é profundamente entalhada, evidenciando seu caráter bilobado. Das oito espécies conhecidas, quatro ocorrem no Brasil e três no litoral do Rio de Janeiro.

\section{Chave para Identificação das Espécies do Gênero Psammobatis}

1a. Coloração dorsal com pontuações escuras fusionadas ou não, formando padrão reticulado; fêmeas com espínulas no lobo posterior das nadadeiras pélvicas (Fig. 287, seta).

Psammobatis lentiginosa

1b. Coloração dorsal sem pontuações escuras fusionadas nem padrão reticulado; fêmeas sem espínulas no lobo posterior das nadadeiras pélvicas (Fig. 288, seta).........2 2a. Com um aguilhão médio-peitoral (Fig. 289, seta A); fileiras de aguilhões médiodorsais contínuas às fileiras de aguilhões caudais (Fig. 289, seta B); com aguilhões na margem do sulco espermático do clásper (Fig. 289, seta C); sulco espermático posicionado dorsalmente no clásper (Fig. 289, seta C); com manchas circulares ou semicirculares circundadas por bordas escuras, menores ou iguais ao diâmetro horizontal do olho, na superfície dorsal do disco; sem pontuações escuras ou agrupamentos de pontos escuros simétricos na região mediana das nadadeiras 
peitorais; sem pontuações esbranquiçadas distribuídas aleatoriamente na superfície dorsal

Psammobatis extenta

2b. Sem aguilhão médio-peitoral (Fig. 290, seta A); fileiras de aguilhões médio-dorsais interrompidas (Fig. 290, seta B); sem aguilhões na margem do sulco espermático do clásper (Fig. 290, seta C); sulco espermático posicionado lateralmente no clásper (Fig. 290, seta C); sem manchas circulares ou semicirculares circundadas por bordas escuras menores ou iguais ao diâmetro horizontal do olho, na superfície dorsal do disco; com pontuações escuras ou agrupamentos de pontos escuros simétricos na região mediana das nadadeiras peitorais; com pontuações esbranquiçadas distribuídas aleatoriamente na superfície dorsal.

Psammobatis rutrum

\section{Psammobatis extenta (Garman, 1913) (Fig. 291)}

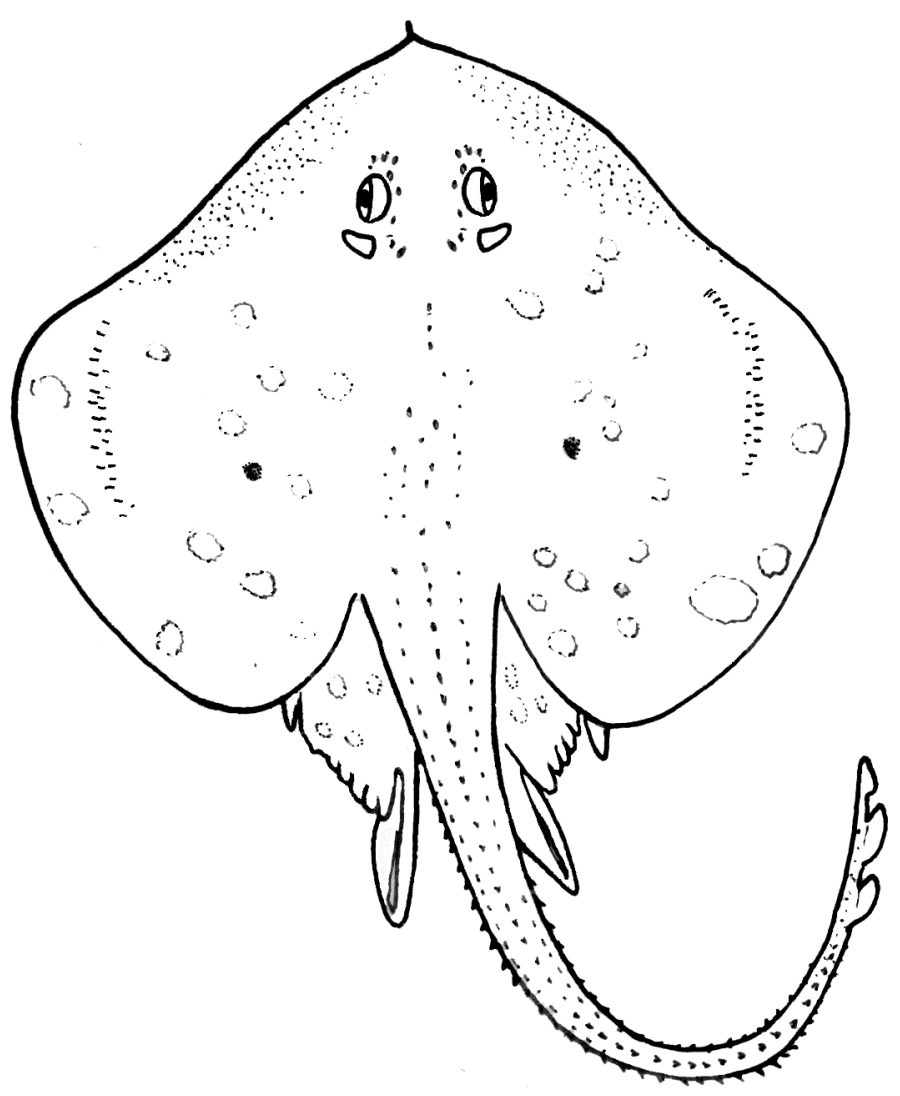

Nome popular: raia-emplastro-mirim.

Caracteres distintivos: com aguilhão médio-peitoral; espinulação médio-dorsal contínua com os aguilhões nucais e escapulares; presença de aguilhões no clásper; sulco espermático em posição dorsal; cauda com três fileiras principais de aguilhões mesclados com aguilhões menores, dispersos aleatoriamente. A coloração padrão é castanha clara ou escura; apresentam muitas manchas mais claras menores, ou iguais, ao diâmetro horizontal do olho, geralmente contornadas por pontos minúsculos. Esses contornos pontuados podem ser completos ou não. Em neonatos estas manchas podem estar ausentes. 
Tamanho: atingem cerca de $31 \mathrm{~cm}$ de CT, com machos maduros em torno de $26 \mathrm{~cm}$ e fêmeas com aproximadamente $25 \mathrm{~cm}$ de CT.

Distribuição, Hábitos e Biologia: sul do Atlântico Ocidental, abrangendo as costa dos Estados do Rio de Janeiro até o Rio Grande do sul, no Brasil, e também Uruguai e norte da Argentina. Assim como as outras espécies do gênero, Psammobatis extenta frequenta águas rasas da plataforma continental. Habitam fundos arenosos, lodosos ou com fragmentos de conchas, em profundidades de 36 a $160 \mathrm{~m}$. Alimentação constituída por pequenos invertebrados bentônicos.

Observações: a espécie Psammobatis extenta é bastante similar e facilmente confundida com Psammobatis rutrum. As fêmeas impõem maiores dificuldades para identificação, uma vez que a distinção das espécies é mais fácil pela observação da morfologia externa dos clásperes. Psammobatis extenta apresenta aguilhões no clásper, e também sulco espermático dorsal ao clasper (em Psammobatis rutrum aguilhoes estão ausentes, e o sulco espermático é lateral ao clasper). A coloração dorsal, devido à grande variabilidade intraespecífica, não é um bom atributo diferencial. A presença do aguilhão médio-peitoral é o caráter diferencial de mais fácil observação, e também com certa consistência para a separação dessas duas espécies (sendo exclusivo de Psammobatis extenta).

\section{Psammobatis lentiginosa McEachran, 1983 (Fig. 292)}

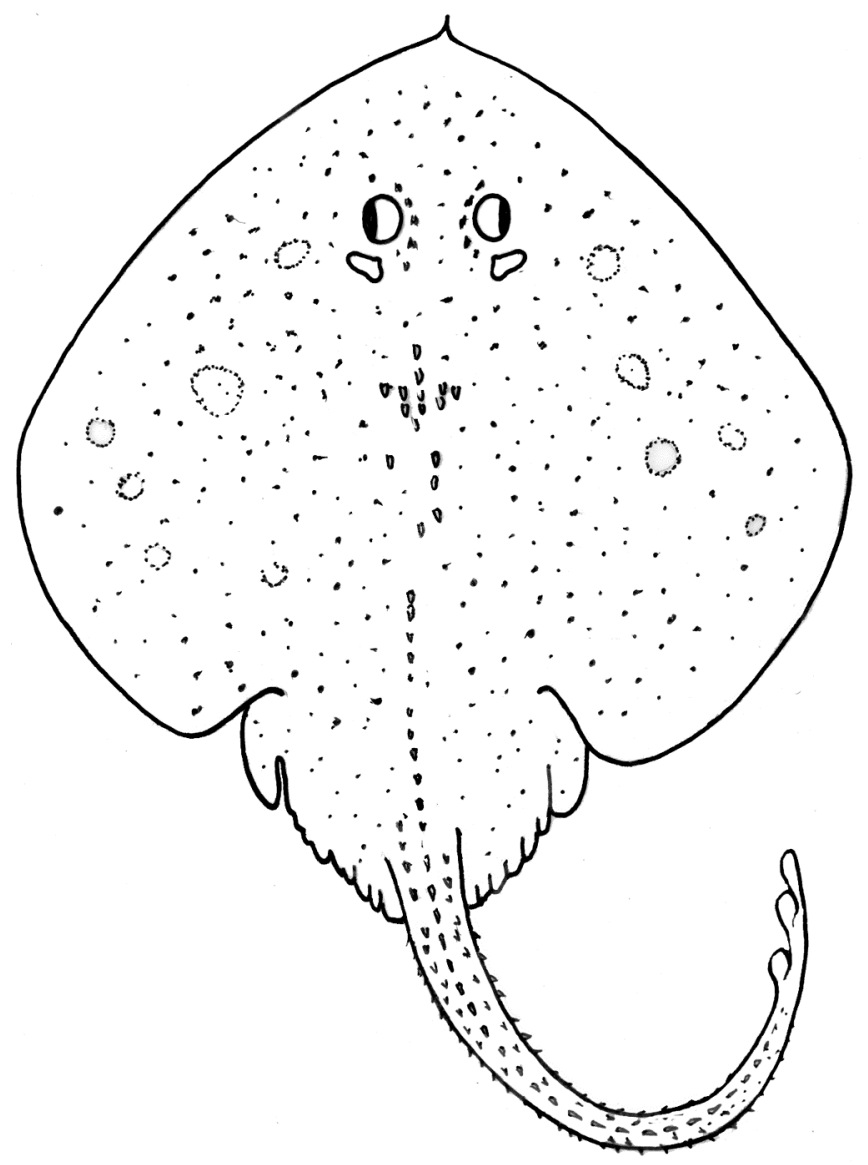


Nome popular: raia-emplasto-mirim.

Caracteres distintivos: caracteriza-se pela redução ou ausência de espinulação na face dorsal do disco, com o tegumento se mostrando liso. Ocorrem aguilhões rostrais, malares, escapulares, supra-escapulares, médio-dorsais e médio-caudais. Nas fêmeas os aguilhões posteriores da pélvica formam aglomerados. Coloração predominantemente castanha escura com pontos negros dispostos aleatoriamente. Os juvenis apresentam manchas circulares com um arranjo espaçado. Com o crescimento, os pontos negros se tornam predominantes e se unem formando um padrão reticulado.

Tamanho: cresce até cerca de $45 \mathrm{~cm}$ de CT; o tamanho da maturidade sexual em ambos os sexos não é bem conhecido; o menor exemplar conhecido mediu $12 \mathrm{~cm}$ de CT ,e este pode ser o tamanho ao nascer.

Distribuição, Hábitos e Biologia: Brasil (Rio de Janeiro ao Rio Grande do Sul), Uruguai eArgentina. Ocorre em fundos de areia elodo entre 30 e $170 \mathrm{~m}$ de profundidade e aparentemente em até cerca de $60 \mathrm{~m}$ mais ao sul. Alimenta-se principalmente de crustáceos e possivelmente outros pequenos invertebrados bentônicos.

Observações: a área de distribuição dessa espécie é intensamente utilizada pela atividade pesqueira, de forma que o risco de afetar negativamente o tamanho de sua população é, no momento, difícil de mensurar. Vale ressaltar que outras espécies de Psammobatis também ocorrem na área, e é provável que, além desta, outras tenham suas populações diminuídas pela frota industrial de arrasto.

Psammobatis rutrum Jordan 1891 (Fig. 293)

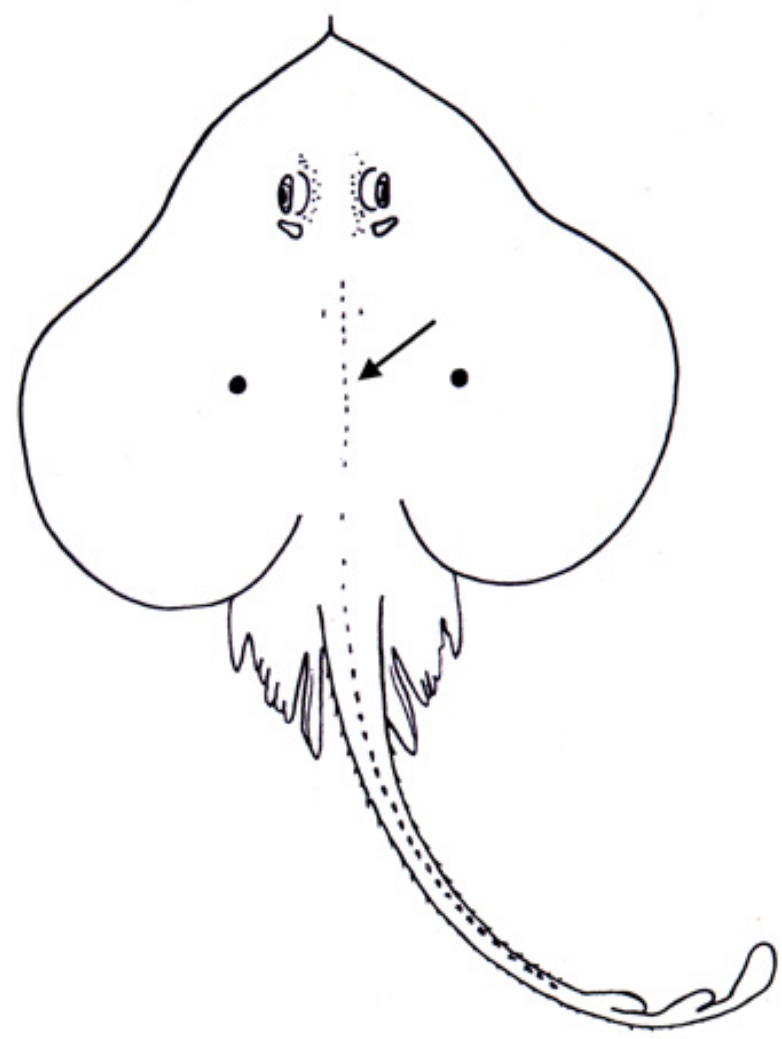


Nome popular: raia-emplastro mirim.

Caracteres distintivos: apresenta um padrão de espinulação bastante característico. O arranjo de aguilhões sofre uma interrupção logo após a região escapular, mas continua (volta a aparecer) posteriormente, em direção à cauda. Coloração dorsal basicamente castanha, podendo variar de escura a clara; uma mancha redonda negra no meio de cada nadadeira peitoral; pontuações esbranquiçadas espalhadas aleatoriamente.

Tamanho: crescem até cerca de $31 \mathrm{~cm}$ de CT; sem dados precisos sobre tamanho de maturidade e ao nascer.

Distribuição, Hábitos e Biologia: ocorre principalmente no Sul do Brasil, Uruguai e norte da Argentina. O registro mais ao norte dessa espécie é o Estado do Espírito Santo. Vive tanto em fundos rochosos como de areia, lama e cascalho, normalmente em profundidades variando de 37 a $100 \mathrm{~m}$. Alimentação constituída de pequenos invertebrados bentônicos.

Observações: os aguilhões rostrais e malares são menos numerosos e mais dispersos nessa espécie do que em Psammobatis extenta. A nadadeira caudal, embora mais desenvolvida do que em Psammobatis extenta, é menor do que a segunda nadadeira dorsal. A distância entre a segunda nadadeira dorsal e a nadadeira caudal é maior em Psammobatis rutrum do que em Psammobatis extenta.

\section{Gênero Sympterygia}

Apresenta ponta do focinho flexível, não sendo a cartilagem rostral observada por transparência. Existe uma única série de aguilhões médio-caudais desenvolvidos; a margem das nadadeiras pélvicas se mostra ligeiramente côncava, com seus lobos não proeminentes. A superfície ventral do disco é clara e a dorsal relativamente áspera em algumas áreas. Distribuição batimétrica para este gênero de 50 até cerca de $700 \mathrm{~m}$, mas também alcançando até $1.500 \mathrm{~m}$.

Ocorrem em ambiente costeiro e estuarino. No quesito alimentação, as dietas das espécies ocorrentes no Rio de Janeiro são similares, tendo sido registrados anelídeos (poliquetas), moluscos (gastrópodes, bivalves, cefalópodes), crustáceos (estomatópodes, misidáceos, tanaidáceos, anfípodas, isópodas, dendobranquiatas, calianassídeos, anomuras, braquiúras), teleósteos e elasmobrânquios. São conhecidas quatro espécies, todas presentes apenas na América do Sul. No Brasil, ocorrem duas espécies (S. bonapartii e S.acuta), ambas no Sudeste e Sul, incluindo a costa do Estado do Rio de Janeiro. 


\section{Chave para Identificação das Espécies do Gênero Sympterygia}

1a. Focinho curto, largura da boca cabendo de 1,5 a duas vezes no comprimento préoral; área dorsal do focinho com coloração escura; aguilhões rostrais desenvolvidos nos adultos (Fig. 294, seta); até três fileiras de aguilhões alares nos machos maduros; aguilhões médio-dorsais ausentes ou, se presentes, não contínuos com os aguilhões médio-caudais (Fig. 294).....

Sympterygia bonapartii

1b. Focinho longo, largura da boca cabendo de 2,5 a três vezes no comprimento pré-oral; área dorsal do focinho com coloração clara; aguilhões rostrais ausentes ou rudimentares nos adultos; até nove fileiras de aguilhões alares nos machos maduros; aguilhões médio-dorsais presentes e contínuos com os aguilhões médio-caudais (Fig. 295, seta).

Sympterygia acuta

\section{Sympterygia bonapartii Müller \& Henle, 1841 (Fig. 296)}

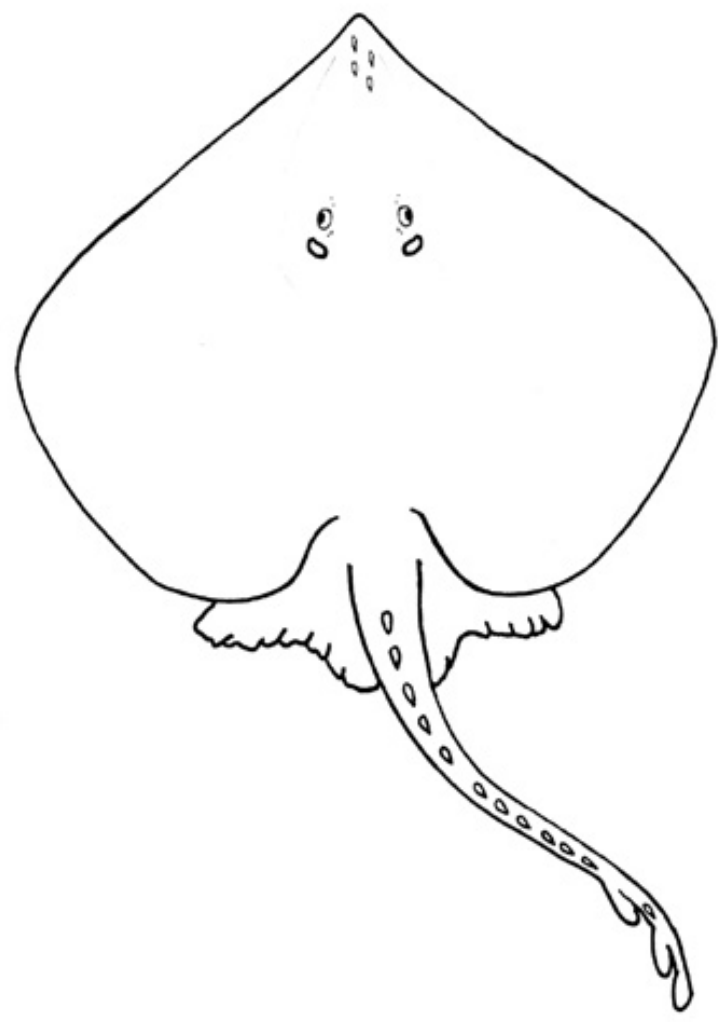

Nome popular: raia-emplastro.

Caracteres distintivos: focinho relativamente curto, variando de $13 \%$ a $15 \%$ do comprimento total; largura da boca cabe de 1,5 a duas vezes no comprimento pré-oral; a margem anterior da nadadeira dorsal é praticamente reta (raramente apresentando uma ondulação suave); presença de um par de aguilhões pré-orbitais e um par de aguilhões pós-orbitais; aguilhões rostrais sempre presentes; fileiras de aguilhões médio-dorsais são incompletas ou inexistentes; até três fileiras de aguilhões alares 
presentes nos machos maduros. O número de dentes de Sympterygia bonapartii varia de 32 a 48, havendo menos dentes nos jovens. Coloração: área dorsal do focinho escura nos adultos. Nos jovens são observadas manchas brancas irregulares sobre a cauda, além de máculas claras e escuras no dorso. Nos exemplares adultos, a região dorsal é castanha escura com manchas negras; a região ventral é esbranquiçada (na maioria dos indivíduos) ou acinzentada; a região ventral da cauda é castanha escura. Tamanho: pode crescer até cerca de $85 \mathrm{~cm}$ de CT; machos amadurecem com aproximadamente $63 \mathrm{~cm}$, e fêmeas, com cerca de $65 \mathrm{~cm}$ de CT; tamanho ao nascer de aproximadamente entre oito e $14 \mathrm{~cm}$ de comprimento, ambos os dados obtidos através da observação da eclosão de cápsulas ovígeras mantidas em laboratório.

Distribuição, Hábitos e Biologia: ocorre do Sudeste ao Sul do Brasil e norte de Buenos Aires, Argentina. Embora tipicamente marinha, foi registrada em água doce. No Brasil, essa espécie é mais abundante em águas rasas, com profundidades inferiores a $50 \mathrm{~m}$, havendo, porém, registros em maiores profundidades também. Alimentação constituída de invertebrados bentônicos e ocasionalmente pequenos peixes ósseos.

Observações: a população dessa espécie aparentemente declinou nos últimos anos em função da pescaria de arrasto industrial.

\section{Sympterygia acuta Garman, 1877 (Fig. 297)}

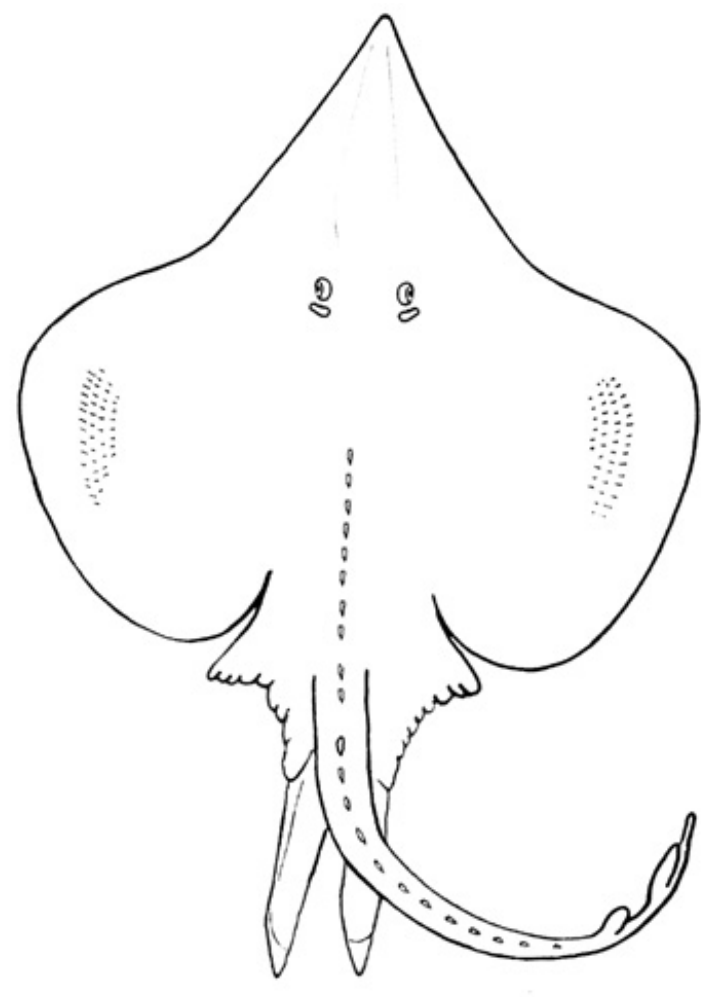

Nome popular: raia-emplastro.

Caracteres distintivos: focinho longo, largura da boca contida de 2,5 a 3,0 vezes no comprimento pré-oral; área dorsal do focinho apresenta coloração clara; aguilhões 
rostrais ausentes ou rudimentares nos adultos; até nove fileiras de aguilhões alares nos machos maduros; aguilhões médio-dorsais presentes e contínuos aos aguilhões médio-caudais. O número de dentes varia de 38 a 54, com menos dentes nos indivíduos jovens. Coloração dorsal castanho uniforme.

Tamanho: cresce até cerca de $65 \mathrm{~cm}$ de CT (a maioria atinge por volta de $50 \mathrm{~cm}$ ); chegam à maturidade sexual com $45 \mathrm{~cm}$ (machos), e $48 \mathrm{~cm}$ (fêmeas) de CT, embora estes dados não sejam precisos porque foram baseados em poucos animais estudados. Distribuição, Hábitos e Biologia: é endêmica do sul das costas argentinas (lado Atlântico) até o Sul do Brasil, ocorrendo também da costa do Estado do Rio de Janeiro a Montevidéu, Uruguai. Mostra-se fortemente associada ao substrato, e não efetua movimentos migratórios. Habita águas de até $40 \mathrm{~m}$ de profundidade, mas há alguns registos em áreas mais profundas (até $180 \mathrm{~m}$, ocasionalmente). A postura e a eclosão dos ovos ocorrem em profundidades inferiores a dez $\mathrm{m}$, o que proporciona ao embrião temperatura adequada para o desenvolvimento. Os machos, quando atingem o comprimento da maturação sexual, não possuem necessariamente mixopterígios funcionais, embora os testículos estejam prontos. Alimentação constituída de invertebrados bentônicos, principalmente crustáceos. Costuma escavar o fundo quando se alimenta, tendo também o hábito de se enterrar no substrato, utilizando as nadadeiras peitorais ou o focinho para escavar o fundo.

Observações: Os caracteres mais utilizados para a identificação das espécies são baseados principalmente na coloração e espinulação.

\section{Gênero Bathyraja}

As principais características diagnósticas do gênero são baseadas em atributos internos (como crânio e clásperes). Algumas espécies apresentam aguilhões apenas na região médio-caudal. A superfície ventral do disco varia de castanho escuro a preta, a ponta do focinho é flexível, a cartilagem rostral não é observada por transparência. Não há arranjo triangular de aguilhões na superfície dorsal da região nucal e escapular do disco. A superfície dorsal do disco é lisa. Ápice do focinho sem espinulação. Nadadeira caudal ausente e nadadeiras dorsais pouco desenvolvidas. Alcançam grande porte, geralmente maiores de $1,5 \mathrm{~m}$ de comprimento total. São mais abundantes em águas temperadas, com grande diversidade no Pacífico Norte, sul do Oceano Atlântico Ocidental e Antártica. Esse gênero apresenta a mais ampla distribuição e riqueza de espécies dentre todos os gêneros conhecidos de raias. Seus representantes são característicos do talude continental e zonas abissais adjacentes, embora, ocasionalmente, possam ser capturados na plataforma continental limítrofe. A maioria das espécies ocorre em profundidades inferiores a 1,00o m, mas algumas podem ultrapassar 2,80o m. O gênero Bathyraja inclui 46 espécies, pelo menos uma delas no Brasil, registrada também na costa do Estado do Rio de Janeiro. 


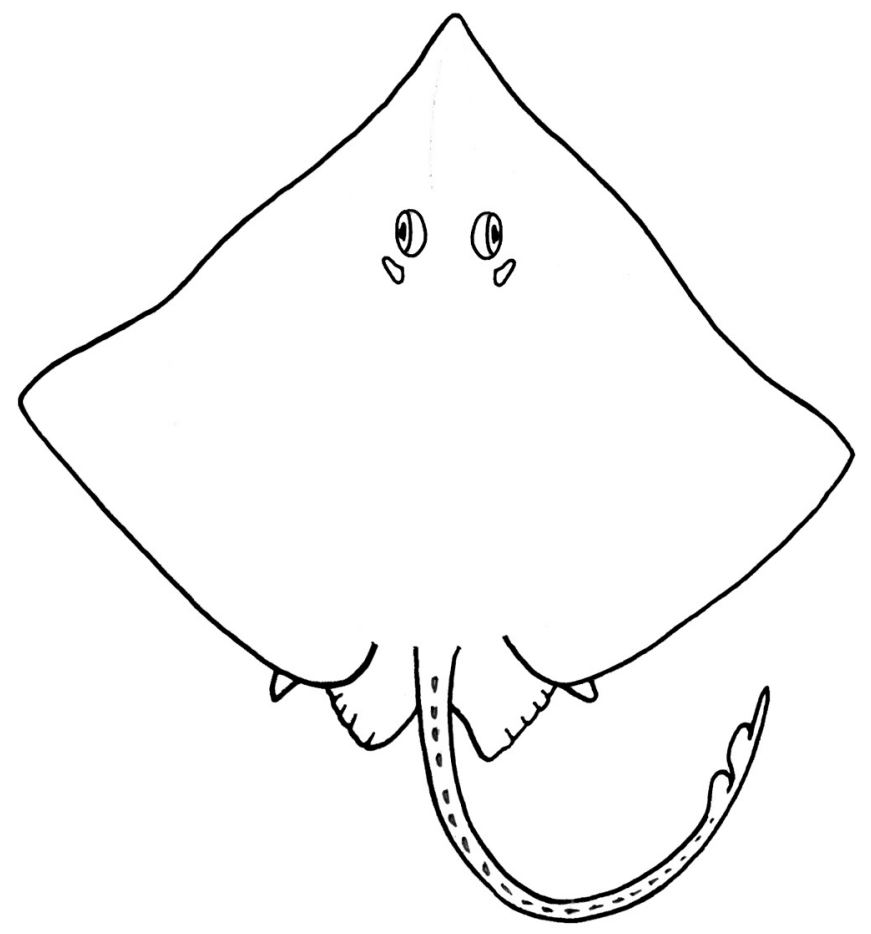

Nome popular: desconhecido.

Caracteres distintivos: aguilhões nucais, escapulares, supra-escapulares e médiodorsais ausentes; presença de uma fileira de aguilhões médio-caudais; um aguilhão interdorsal. Focinho curto, correspondendo a pouco mais de $10 \%$ do comprimento total; face inferior do disco escura, exceto a região da boca, em volta da abertura anal e ápice dos lobos anteriores das nadadeiras pélvicas. Manchas claras são observadas próximas ao focinho, nas fendas branquiais e adjacências, ao redor da boca, no ventre, ao redor da abertura anal, no ápice das pélvicas e base da nadadeira caudal.

Distribuição, Hábitos e Biologia: distribuição restrita ao Oceano Atlântico Sul ocidental e Pacífico Sul oriental (Chile). Poucos exemplares foram coletados, em grandes profundidades, entre 800 e 3,00o m. O exemplar do Brasil foi capturado entre 2.370 e $2.380 \mathrm{~m}$ de profundidade. Biologia desconhecida. Reprodução possivelmente ovípara como outros Rajidae. Alimentação possivelmente constituída de pequenos peixes e invertebrados bentônicos.

Observações: trata-se de uma espécie bastante rara, conhecida até o presente por apenas seis exemplares. Consequentemente sua biologia é pouco conhecida. O exemplar brasileiro, possivelmente por ser recém-nascido, é inteiramente claro tanto dorsal quanto ventralmente. Trata-se de uma fêmea de $24,6 \mathrm{~cm}$ de comprimento total, capturada nas coordenadas de $23^{\circ} \mathrm{O} 4^{\prime} \mathrm{S}, 40^{\circ} 19^{\prime} \mathrm{W}$ (costa do Estado do Rio de Janeiro). 


\section{Ordem MYLIOBATIFORMES}

Os representantes dessa ordem possuem as nadadeiras peitorais bem expandidas lateralmente, formando um disco largo. Todos os Myliobatiformes exibem a parte posterior do corpo (região caudal) pouco desenvolvida, alongada e em forma de chicote, sem terminar em nadadeira caudal (exceto os representantes da família Urotrygonidae, que tem uma pequena nadadeira caudal, mas esta família não é registrada na costa do Estado do Rio de Janeiro). Algumas vezes possuem uma única nadadeira dorsal na base do filamento caudal, e a maioria das espécies porta um ferrão serrilhado na base ou região mediana da cauda em chicote. Nessa ordem, encontram-se as maiores raias quanto à $\mathrm{LD}$, podendo variar de um a sete metros. A maioria habitante de águas costeiras de regiões tropicais até temperadas, e uma família (Potamotrygonidae) que vive restrita à água doce. Os Myliobatiformes (ou raias de ferrão) formam um grupo diverso e numeroso, com dez famílias, cerca de 23 gêneros e mais de 190 espécies. No Brasil, há representantes de sete famílias: Potamotrygonidae, Urotrygonidae, Dasyatidae, Gymnuridae, Myliobatidae, Rhinopteridae e Mobulidae; 13 gêneros e cerca de 45 espécies. Dessas, Urotrygonidae e Potamotrygonidae são praticamente restritas à água doce, habitando as grandes bacias sul-americanas (uma espécie de Potamotrygonidae, Styracura schmardae, ocorre no Brasil, em ambientes de água salgada). Na costa do Estado do Rio de Janeiro os Myliobatiformes são representados por cinco famílias, oito gêneros e 17 espécies.

\section{Chave para Identificação das Famílias da Ordem Myliobatiformes}

1a. Sem nadadeira dorsal sobre a base da cauda (Fig. 299, seta) .2

1b. Com uma nadadeira dorsal sobre a base da cauda (Fig. 300, seta)............................3 2a. Largura do disco muito maior do que o comprimento do corpo, mesmo incluindo o chicote caudal (Fig. 301). Gymnuridae 2b. Largura do disco igual ou menor do que o comprimento do corpo, incluindo o chicote caudal (Fig. 302). Dasyatidae

3a. Com ou sem ferrão serrilhado na base da cauda; cabeça com duas projeções anteriores laterais, dando aspecto de chifre (Fig. 303, seta).

Mobulidae

3b. Com ferrão serrilhado na base da cauda, cabeça terminando em ponta ou com um entalhe mediano frontal, mas nunca com duas projeções anteriores laterais similares a um chifre (Fig. 304, seta).

4a. Cabeça com entalhe profundo na região mediana anterior (Fig. 305, seta), não terminando em ponta mais arredondada .... Rhinopteridae 4b. Cabeça sem entalhe profundo na região mediana anterior e termina em ponta, mais arredondada e mais aguda (Fig. 306, seta).

5a) Uma única série de dentes em ambas as arcadas dentárias (Fig. 307, seta) 
5b) De uma a sete séries de dentes em ambas as arcadas dentárias (Fig. 308, seta)...

Myliobatidae

\section{Família GYMNURIDAE}

Corpo bem achatado dorso-ventralmente, com cabeça, tronco e nadadeiras peitorais expandidas formando o disco romboidal; largura do disco cabendo no mínimo 1,5 vezes no comprimento do corpo; cauda bastante delgada, porém reduzida (marcadamente menor que a LD) e distintamente demarcada do disco; nadadeiras peitorais contínuas ao longo das laterais da cabeça, sem formar lobos carnosos subrostrais ou projeções cefálicas laterais como chifres; olhos e espiráculos no topo da cabeça; algumas espécies possuem tentáculos (pequenas projeções carnosas) espiraculares; focinho obtuso. As cortinas nasais se expandem lateralmente e são contínuas na frente da boca, a qual tem abertura arqueada. Os dentes são pequenos, com uma única cúspide, e dispostos em bandas. Sem nadadeiras dorsais e caudais. Com ou sem ferrões serrilhados na base da cauda, que possui dobras longitudinais na sua superfície dorsal e/ou ventral. A maioria das espécies tem pele lisa, sem dentículos dérmicos, mas podem apresentar número variado de tubérculos em alguns indivíduos. São cosmopolitas em águas tropicais e temperadas; geralmente se encontram em substrato arenoso ou lamoso em águas rasas costeiras, incluindo estuários e desembocaduras de rios. São frequentemente capturadas por redes-dearrasto-de-fundo. Essa família é representada por um gênero e cerca de 13 espécies conhecidas no mundo (Yokota et al., 2016, Yokota \& Carvalho, 2017).

\section{Gênero Gymnura}

As características diagnósticas da família são suficientes para distinguir esse gênero. São conhecidas cerca de 13 espécies no mundo, três delas no Brasil (G. altavela, G. lessae e G. micrura), e duas ocorrendo na costa do Estado do Rio de Janeiro.

\section{Chave para Identificação das Espécies do Gênero Gymnura}

1a. Com tentáculo na margem posterior do espiráculo (Fig. 309, seta A); com um ou mais ferrões serrilhados na cauda (Fig. 309, seta B) Gymnura altavela 1b. Sem tentáculo na margem posterior do espiráculo (Fig. 310, seta A); sem ferrões serrilhados na cauda (Fig. 310, seta B).

Gymnura micrura 


\section{Gymnura altavela (Linnaeus, 1758) (Fig. 311)}

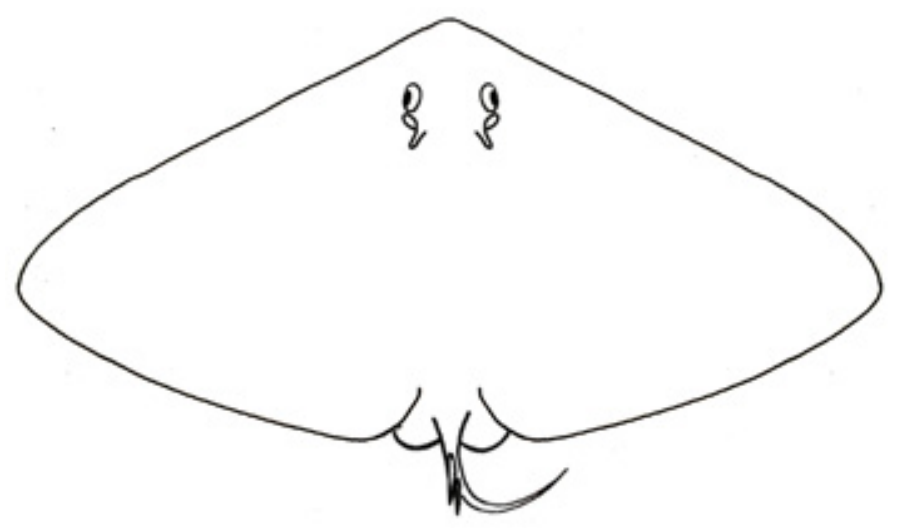

Nomes populares: raia-borboleta, raia-mariposa, paraty.

Caracteres distintivos: difere de Gymnura micrura por apresentar um ou mais ferrões na cauda e margem posterior do espiráculo com apêndice em forma de tentáculos. Coloração do dorso castanha escura a clara com pequenos pontos ou manchas pequenas, mais escuras ou claras, irregularmente espalhadas no disco; ventre claro, tendendo ao bege.

Tamanho: atinge cerca de dois $\mathrm{m}$ de $\mathrm{LD}$, com registros duvidosos de exemplares de até quatro metros; maturidade sexual dos machos com cerca de $80 \mathrm{~cm}$ de LD, sem dados precisos para as fêmeas; tamanho ao nascer cerca de 25 a $30 \mathrm{~cm}$ de LD.

Distribuição, Hábitos e Biologia: distribuição esparsa ao longo do Oceano Atlântico ocidental, desde Massachusetts até o norte da Argentina. Registrada também no Oceano Atlântico oriental. Bentônica, em águas rasas de até $55 \mathrm{~m}$ de profundidade, com registros raros até $100 \mathrm{~m}$. Adultos aparentemente se reproduzem em águas muito rasas e depois se afastam para águas mais profundas. Esta espécie é vivípara lecitotrófica, com suporte nutricional dos fetos também através de trofonemata. Geram de dois a seis embriões por vez. Alimenta-se de moluscos bivalves e crustáceos. Observação: capturada frequentemente com arrastos de praia, principalmente no Norte e Nordeste do Brasil.

Gymnura micrura (Bloch \& Schneider, 1801) (Fig. 312)

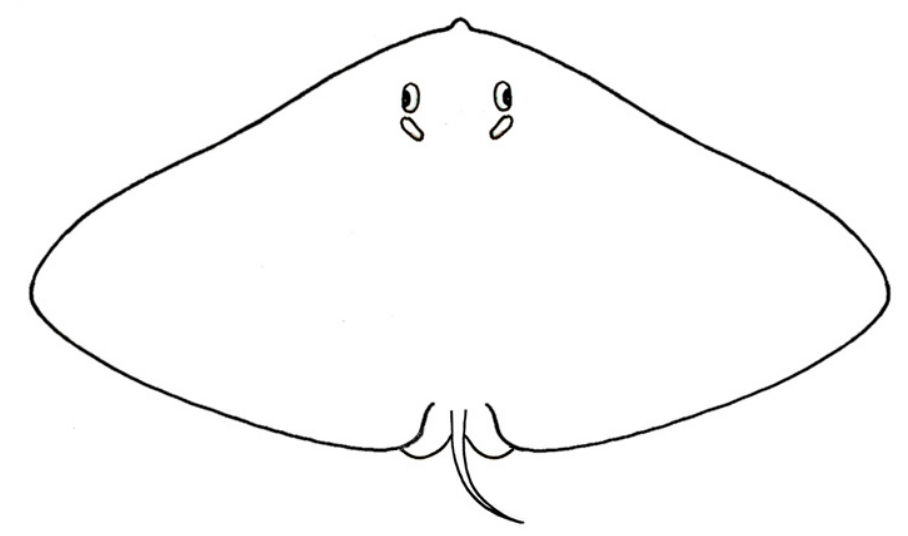


Nome popular: raia-borboleta, paraty.

Caracteres distintivos: difere-se de G. altavela por conta da ausência de ferrão na cauda e pela ausência de apêndice em forma de tentáculo na margem posterior do espiráculo. Coloração do dorso acinzentada, castanha, olivácea clara ou arroxeada, com padrões de manchas de cores claras ou escuras na cauda; ventre esbranquiçado com moldura externa do disco cinza.

Tamanho: um pouco menor do que a espécie anterior, com LD entre $90 \mathrm{~cm}$ e 1,2 $\mathrm{m}$; machos e fêmeas atingem a maturidade sexual por volta de 42 e $50 \mathrm{~cm}$ de LD respectivamente; recém-nascidos medem de 16 a $22 \mathrm{~cm}$ de largura.

Distribuição, Hábitos e Biologia: registrada de Cheasapeake Bay (EUA) ao Rio de Janeiro; comum no Golfo do México, mas não ocorre nas Pequenas e Grandes Antilhas. Registros de G. micrura nos oceanos Atlântico Oriental, Índico e Pacífico provavelmente se referem à outra(s) espécie(s). É bentônica em águas costeiras de substrato arenoso, mas também ocorre em estuários. Como em Gymnura altavela, nessa espécie os adultos aparentemente se reproduzem em águas muito rasas e depois se dirigem para áreas mais fundas. Espécie vivípara lecitotrófica, com suporte nutricional dos fetos também por trofonemata. Pode gerar de um a oito embriões por vez (na maioria das vezes, entre três e cinco). Alimenta-se preferencialmente de crustáceos, moluscos com conchas e de peixes.

\section{Família DASYATIDAE}

Raias de tamanho moderado a grande, com LD desde $30 \mathrm{~cm}$ até mais de dois metros. Formato do disco circular, trapezoidal ou em diamante (Figs. 313 a 322). Medida da LD igual ou menor do que o CT. Superfície dorsal do disco e da cauda lisa (Fig. 318, seta A) ou com faixas de dentículos dérmicos diminutos, conferindo um aspecto de lixa (Fig. 318, seta B) e/ou com uma linha mediana de tubérculos lanceolados (Fig. 318, setas C e D). A presença desses dentículos pode depender da espécie ou, intraespecificamente, da maturidade do indivíduo. Margem anterior das nadadeiras peitorais retas ou arqueadas. Focinho obtuso, arredondado ou um tanto pontiagudo, às vezes com uma pequena protuberância sobressaindo ao contorno anterior do disco. Olhos e espiráculos no topo da cabeça. Assoalho da boca com papilas orais; dentição pavimentosa com dentes planos em fêmeas e juvenis, e com uma ou mais cúspides em machos adultos no período reprodutivo. Cauda visivelmente filamentosa e diferenciada do disco, formando um chicote, com ou sem uma dobra dorsal e ventral (ou somente uma delas). Ou então, com uma crista rudimentar, somente na área dorsal do chicote. Não há nadadeiras dorsais ou nadadeira caudal. Presença de ferrão serrilhado no filamento caudal, próximo à base da cauda. Essas raias ocorrem principalmente na região costeira de águas tropicais até temperadasquentes, ocasionalmente também em água doce. Algumas poucas espécies podem habitar águas profundas (em torno de $1000 \mathrm{~m}$ ). São predominantemente bentônicas e 
permanecem por longos períodos parcialmente enterradas em substrato. A exceção, Pteroplatytrygon violacea, é epipelágica, nadando ativamente em oceanos abertos e ao longo das margens de plataformas continentais e insulares. Muitos acidentes com raias envolvem essa família. Podem causar ferimentos extremamente dolorosos por conta de seus ferrões caudais. Acidentes de maior gravidade, envolvendo morte, são extremamente raros, pois são invariavelmente animais dóceis e tímidos que evitam o homem. São conhecidos 19 gêneros e cerca de 89 espécies no mundo. Cinco gêneros, sete ou oito espécies são encontrados no Brasil, onde quatro gêneros (Dasyatis, Bathytoshia, Hypanus e Pteroplatytrygon) e cinco espécies ocorrem no Rio de Janeiro.

A chave de identificação para os gêneros desta família é útil apenas para os representantes desta região.

\section{Chave para Identificação dos Gêneros da Família Dasyatidae}

1a) Margem anterior do disco convexa a reta (Fig. 313, seta); adultos com coloração ventral escura uniforme.

1b) Margem anterior do disco subangular (Fig. 314, seta); adultos com coloração ventral clara. .2

2a) Face ventral do disco com uma marca em baixo relevo em forma de "W" abaixo do quinto par de fendas branquiais (Fig. 315, seta); aba caudal dorsal presente, crista caudal dorsal ausente

Dasyatis

2b) Face ventral do disco sem marca em baixo relevo em forma de "W" abaixo do quinto par de fendas branquiais (Fig. 316); aba caudal dorsal ausente, presença de crista dorsal caudal, mais nítida nos adultos.

3a) Com tubérculos distribuídos aleatoriamente na face dorsal do disco e na lateral da cauda (Fig. 317, seta) em exemplares a partir de $40 \mathrm{~cm}$ de largura do disco; exemplares maiores podem exibir uma fileira de tubérculos medianos dorsais, cônicos-achatados, desde a região nucal até a base do chicote dorsal; geralmente a região dorsal do disco possui riscos semelhantes a cicatrizes; ausência de tubérculos organizados em uma fileira mediana dorsal, em forma de ponta de lança, desde a região nucal até a origem do ferrão

Bathytoshia

3b) Sem tubérculos distribuídos aleatoriamente na face dorsal do disco e na lateral da cauda (Fig. 318, seta A); região dorsal do disco sem riscos semelhantes a cicatrizes; presença de tubérculos organizados em uma fileira mediana dorsal, em forma de ponta de lança (Fig. 318, seta C), desde a região nucal até a origem do ferrão (Fig. 318, seta $\mathrm{C}$ e D)

Hypanus 


\section{Gênero Dasyatis}

Margem anterior do disco subangular, com extremidade do focinho formando o ápice do ângulo. A coloração ventral do disco é predominantemente clara, mas algumas espécies exibem manchas escuras. Conhecidas cinco espécies no mundo, e uma no Brasil que ocorre na costa do Estado do Rio de Janeiro (Dasyatis hypostigma).

Dasyatis hypostigma Santos \& Carvalho, 2004 (Fig. 319)

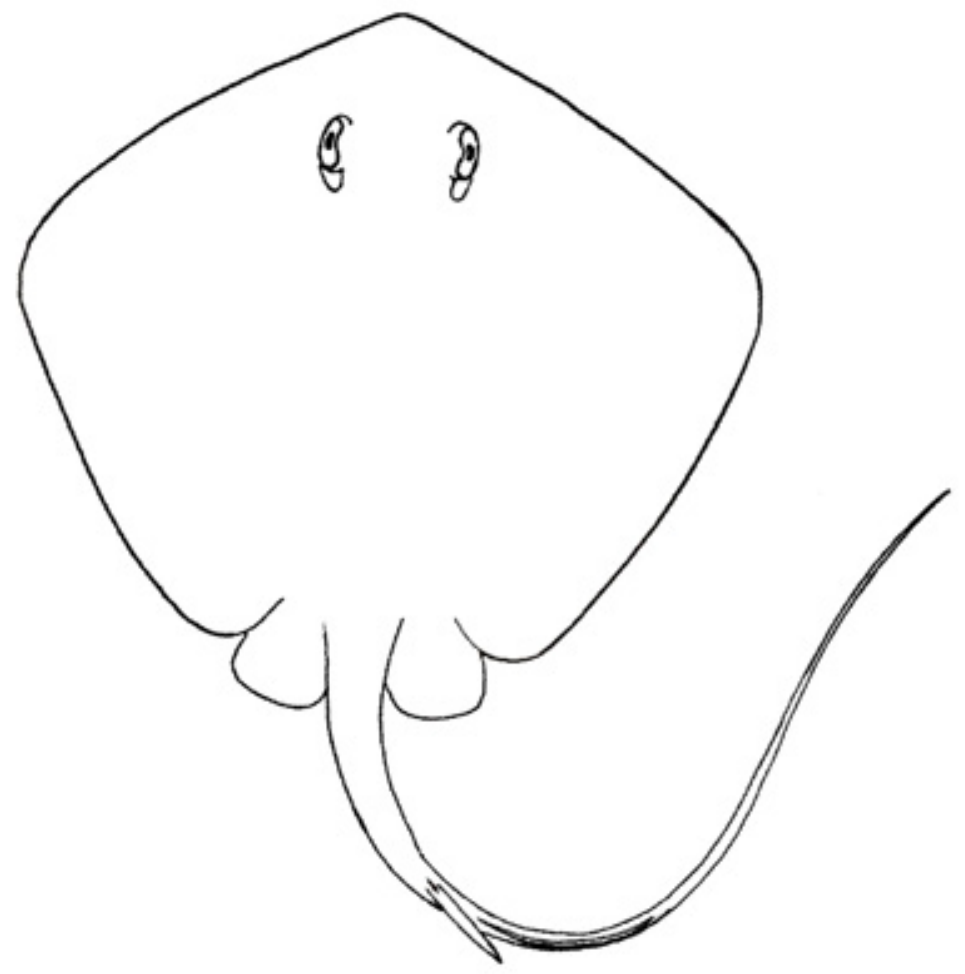

Nomes populares: raia-manteiga, raia mijona-lisa.

Caracteres distintivos: apresenta sulco sinuoso e raso na parte ventral do disco em forma de "W" (Fig. 315); ponta do focinho não se projetando muito além da margem anterior do disco (ausência de protuberância no focinho); abas caudais dorsal e ventral mais ou menos da mesma altura, sendo que a aba ventral é bem mais longa que a dorsal; corpo inteiramente liso nos indivíduos até $30 \mathrm{~cm}$ de LD; após este tamanho alguns exemplares maduros podem apresentar pequeninos dentículos dérmicos espaçados na superfície dorsal do corpo e na base do chicote caudal, perceptíveis ao tato. Coloração dorsal castanha, castanha-oliva ou castanha amarelada, ocasionalmente com nuances azuladas dispersas. Quando em vida, as margens do disco são delineadas por uma fina linha de cor azul brilhante. Superfície ventral do disco esbranquiçada, podendo apresentar manchas escuras e esparsas na região branquial; dobras caudais pretas em espécimes vivos ou recém-capturados.

Tamanho: cresce até cerca de $58 \mathrm{~cm}$ de LD. Machos amadurecem com cerca de 30 $\mathrm{cm}$, e nas fêmeas este dado não é bem conhecido, mas possivelmente com mais do 
que $30 \mathrm{~cm}$ de largura; tamanho ao nascer estimado entre dez e $12 \mathrm{~cm} \mathrm{LD}$, com base num único exemplar que carregava embriões ainda não completamente formados, medindo entre 5,5 e 5,6 cm de LD, mas existem dados de exemplares examinados em coleções científicas, que mediam entre 7,5 e 11,5 cm de LD (supostamente embriões também).

Distribuição, Hábitos e Biologia: distribui-se do Estado do Espírito Santo ao Estado do Rio Grande do Sul, mas provavelmente ocorre até Mar Del Plata (Argentina). Preferem águas costeiras rasas de até $80 \mathrm{~m}$ de profundidade, podendo ocorrer em regiões estuarinas. Espécie vivípara lecitotrófica, com suporte nutricional também por trofonemata. Geralmente dão a luz a dois embriões por fêmea. A alimentação é constituída, principalmente, de poliquetas e crustáceos.

\section{Gênero Bathystoshia}

Os indivíduos juvenis e subadultos são inteiramente lisos, sem dentículos dérmicos sobre o corpo. Conforme o crescimento, surgem tubérculos distribuídos aleatoriamente, na face dorsal do disco e na lateral da cauda.

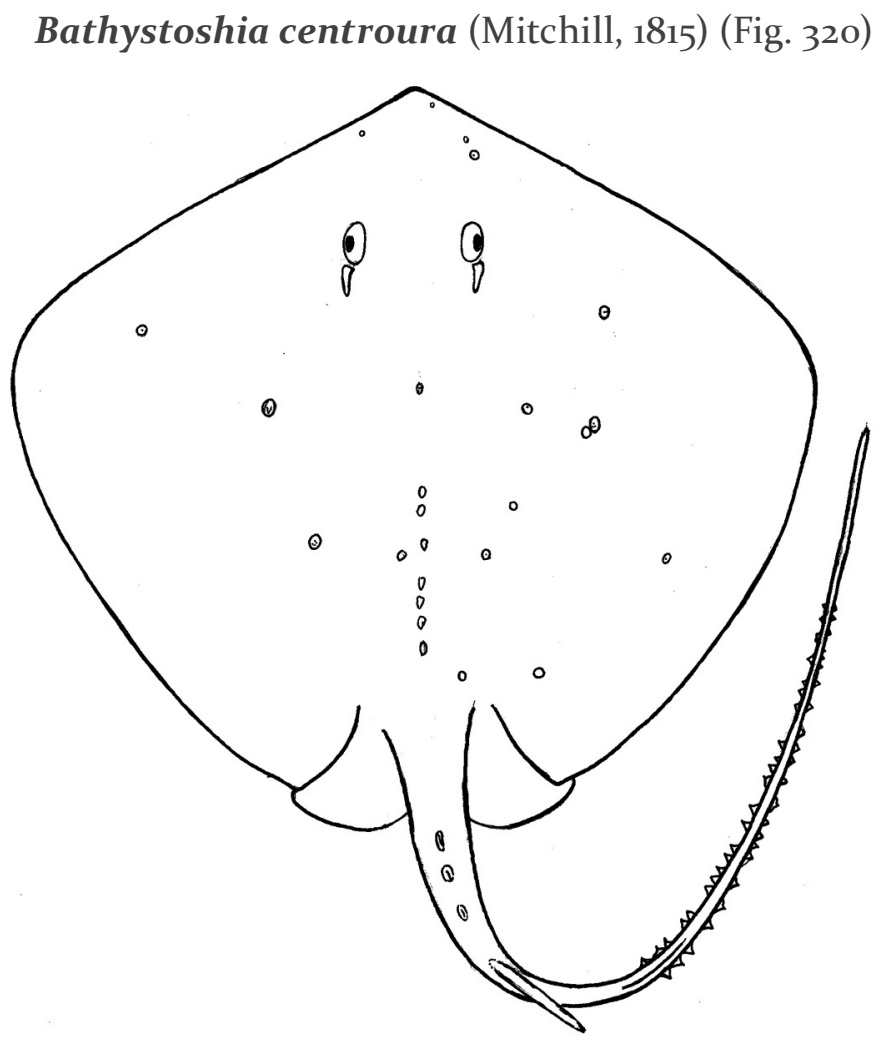

Nomes populares: raia-prego, raia-manteiga.

Caracteres distintivos: disco em formato de diamante; ponta do focinho não sobressaindo do contorno anterior do disco; extremidade lateral das nadadeiras 
pélvicas arredondadas; distribuição da espinulação do tronco ausente (juvenis), ou apresentando tubérculos (adultos a partir de cerca de $40 \mathrm{~cm}$ da largura do disco) sobre o disco e na cauda (Fig. 317). Com o crescimento do exemplar os tubérculos tornam-se cada vez mais desenvolvidos, podendo se fusionar formando pesadas placas protetoras. Há registros fotográficos de exemplares maiores de um metro de $\mathrm{LD}$, em que é visível uma fileira mediana dorsal de tubérculos, começando na nuca e chegando à base do chicote caudal. Entretanto outros exemplares do mesmo tamanho não mostram essa característica, o que pode sugerir que existam espécies diferentes de Bathystoshia.

Apenas a dobra caudal ventral está presente no chicote caudal. A coloração dorsal do corpo uniformemente castanha escura a oliva; ventre claro. Um caráter que não se pode determinar como "coloração", mas como uma observação quase constante nesses animais, é a superfície dorsal do disco apresentando rabiscos, como se estivesse arranhada. Talvez isso possa ser explicado pela delicadeza do tegumento dessas raias, que deve sofrer arranhões resultantes de qualquer atrito no meio em que vivem.

Tamanho: é a maior espécie de Dasyatidae do Atlântico ocidental, podendo medir até 2,6 $\mathrm{m}$ de $\mathrm{LD}$; a maturidade sexual se dá entre 1,3 e 1,5 $\mathrm{m}$ de LD nos machos, e entre 1,4 e 1,6 m nas fêmeas.

Distribuição, Hábitos e Biologia: registrada desde Georges Bank e Cape Cod até sul da Flórida, Estados Unidos, norte e nordeste do Golfo do México, Bahamas, Nordeste do Brasil à Argentina (também registrada no Oceano Atlântico Oriental e no Mar Mediterrâneo, mas talvez sejam espécies diferentes). É bentônica, ocorrendo ao longo de plataforma continental, a até $91 \mathrm{~m}$ de profundidade, raramente aos 274 m. Vivípara lecitotrófica, com suporte nutricional adicional por trofonemata, parindo de dois a quatro embriões por vez. Dieta constituída basicamente de poliquetas, moluscos cefalópodes, crustáceos e peixes ósseos pequenos.

\section{Gênero Hypanus}

Focinho curto, com comprimento pré-oral menor que $25 \%$ no comprimento do disco.

Observações: até recentemente a espécie Dasyatis sayi (atualmente reconhecida taxonomicamente como Hypanus sayi) era registrada para a costa brasileira e confundida com Dasyatis hypostigma. Difere principalmente pela presença do sulco em forma de "W" na face mediana ventral do disco (D. hypostigma). Hypanus sayi aparentemente é restrita ao Atlântico Norte ocidental e possivelmente ocorre no norte e nordeste Brasil, faltando confirmação. Estudos taxonômicos mais cuidadosos na costa Norte e Nordeste poderão fornecer informações que auxiliem no entendimento do limite norte de distribuição de $D$. hypostigma e limite sul de distribuição de $H$. sayi. Duas espécies ocorrem na região, H. americanus e H. guttatus. 


\section{Chave para Identificação das Espécies do Gênero Hypanus}

1a) Focinho curto, comprimento pré-oral menor que $25 \%$ do comprimento do disco (Fig. 321) Hypanus americanus 2b) Focinho longo, comprimento pré-oral igual ou maior que $25 \%$ do comprimento do disco (Fig. 322). Hypanus guttatus

Hypanus americanus (Hildebrand and Schroeder, 1928) (Fig. 323)

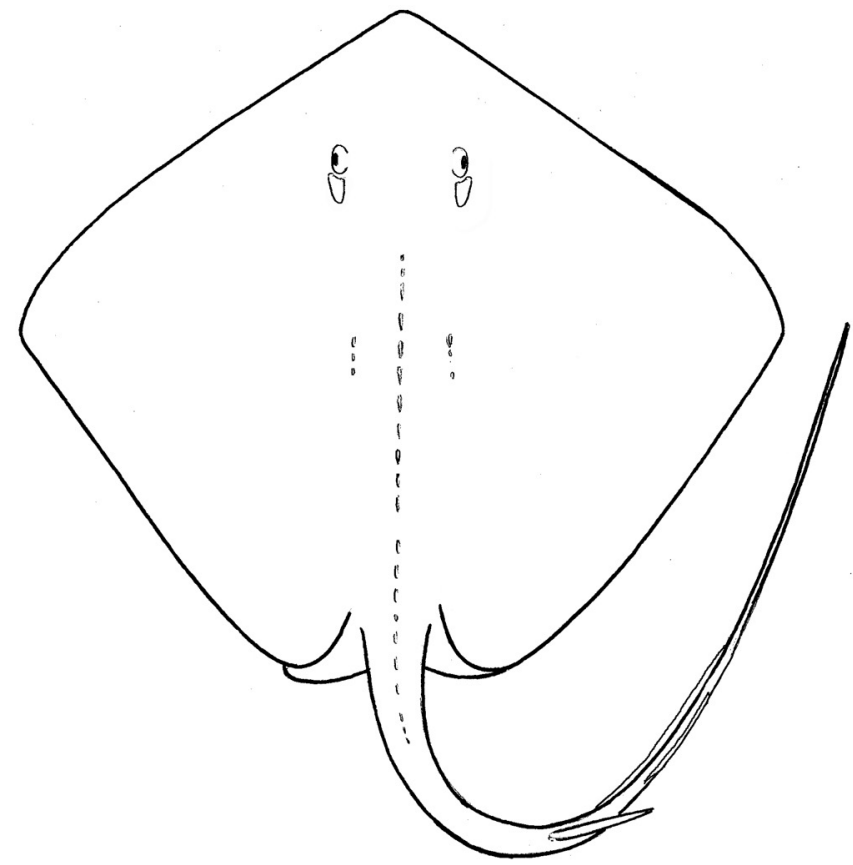

Nomes populares: raia-manteiga com espinho; raia-prego.

Caracteres distintivos: disco em formato de diamante; ponta do focinho não sobressaindo do contorno anterior do disco; extremidade lateral das nadadeiras pélvicas arredondadas; linha mediana do tronco com uma fileira de tubérculos (Fig. 318, seta C); pequena fileira longitudinal de tubérculos escapulares em cada lado da linha mediana (Fig. 318, seta E). Crista dorsal e uma dobra caudal ventral presentes no chicote caudal. Fileira mediana de tubérculos lanceolados irregulares (juvenis e indivíduos menores) ou regulares (adultos) alinhados desde a região nucal até a base da cauda, podendo prosseguir por ela (Fig. 318, setas C e D). Coloração dorsal do disco castanha clara, cinza ou oliva, variando de acordo com o substrato; ventralmente branca com margens cinza ou castanhas; dobras dérmicas na cauda escuras.

Tamanho: cresce até cerca de 1,5 $\mathrm{m}$ de LD; machos maduros com cerca de $50 \mathrm{~cm}$ de LD. Nos machos e nas fêmeas a maturidade se dá com cerca de 75 a $80 \mathrm{~cm}$; tamanho ao nascer em torno de 17 a $34 \mathrm{~cm}$ de LD.

Distribuição, Hábitos e Biologia: encontra-se desde New Jersey a Flórida, Estados Unidos, passando pelo Golfo do México, Bahamas, Pequenas e Grandes Antilhas, beirando a costa norte da América do Sul até o Sudeste brasileiro. Habita águas 
rasas, enterrando-se em substrato arenoso (raramente em fundos lamosos), em profundidades de até $60 \mathrm{~m}$. Nadadora ativa, migrando nos meses de verão de águas superficiais para latitudes mais elevadas. Encontra-se em águas de temperatura entre $15,4^{\circ} \mathrm{C}$ e $30,3^{\circ} \mathrm{C}$, geralmente em altas salinidades $(28,5-36,2)$, porém ocasionalmente ingressa em estuários e água doce. Espécie vivípara lecitotrófica, com suporte nutricional por trofonemata, parindo de dois a dez embriões a cada gestação. Alimenta-se principalmente moluscos bivalves, anelídeos, crustáceos (camarões e caranguejos) e pequenos peixes ósseos.

Observações: no Brasil a sua ocorrência tem sido mais reportada nas ilhas oceânicas do Nordeste (Fernando de Noronha e Atol das Rocas), onde é frequentemente encontrada por mergulhadores. Pode ocasionar lesões consideráveis em função do ferrão caudal desenvolvido, mas dada a sua relutância ao contato com humanos, a possibilidade de acidentes graves é baixa.

Hypanus guttatus (Bloch \& Schneider, 1801) (Fig. 324)

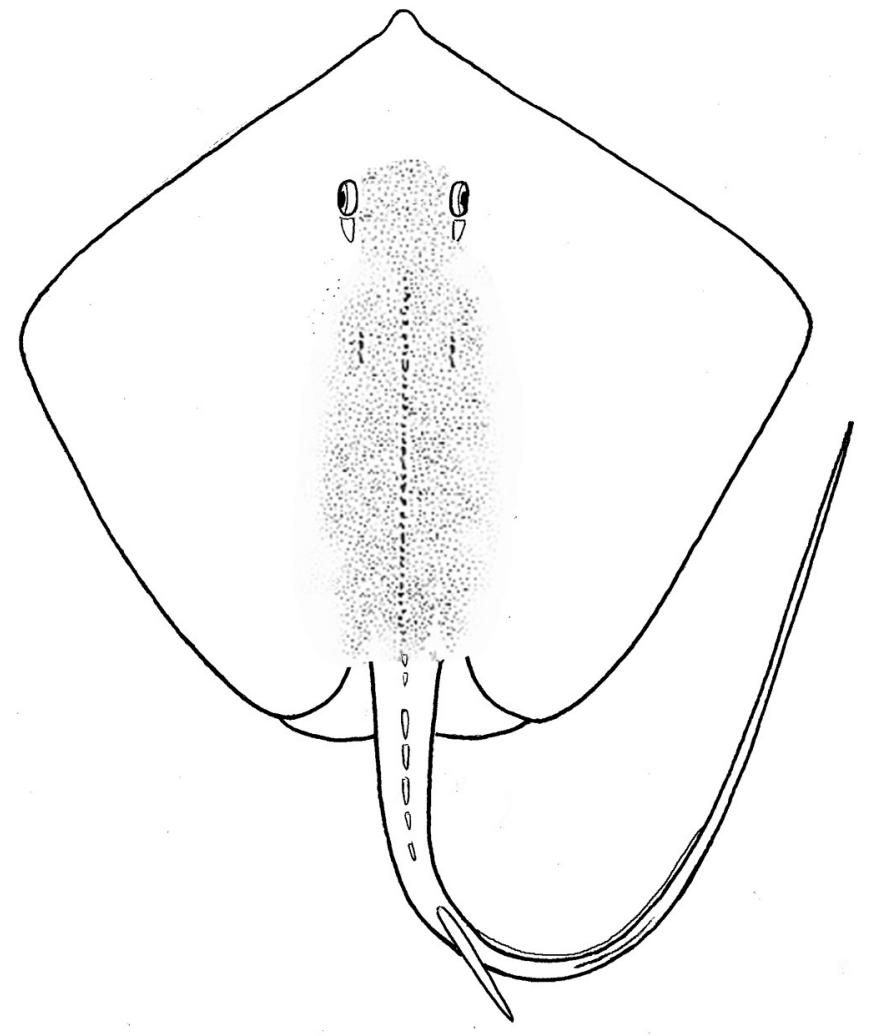

Nomes populares: raia-lixa, raia-branca; raia-bico-de-remo.

Caracteres distintivos: disco em forma de diamante; ponta do focinho pronunciada, com protuberância sobressaindo ao contorno anterior do disco; extremidade das nadadeiras pélvicas arredondada; espinulação do dorso com uma fileira mediana de tubérculos lanceolados (Fig. 318, seta C), e com uma larga faixa áspera, longitudinal de pequeninos tubérculos no dorso (Fig. 318, seta B) (daí o nome popular de raialixa); tubérculos escapulares presentes (Fig. 318, seta E); cauda com crista dorsal 
e dobra ventral. Coloração do dorso cinza, castanha ou oliva, podendo apresentar pontuações escuras; coloração do ventre branca a amarelada; crista e dobra caudais escuras.

Tamanho: pode medir até dois $\mathrm{m}$ de LD; machos maduros com cerca de 40 a $50 \mathrm{~cm}$ de LD e, supostamente, a partir de $75 \mathrm{~cm}$ em fêmeas; nascem medindo cerca de 15 a $20 \mathrm{~cm}$ de LD.

Distribuição, Hábitos e Biologia: espalhada pelo sul do Golfo do México, Antilhas, norte da América do Sul até sul do Brasil (pelo menos até o Estado do Paraná). Habita águas rasas, tropicais e subtropicais, até cerca de $35 \mathrm{~m}$ de profundidade. Vivípara lecitotrófica, com suporte nutricional por trofonemata, parindo até seis embriões, embora com poucos dados a esse respeito. Possui dieta preferencial por crustáceos, incluindo também outros grupos como poliquetas e moluscos.

Observações: a maioria dos levantamentos faunísticos realizados no Norte e Nordeste inclui essa espécie, sugerindo ser mais abundante naquelas áreas. A presença de um ferrão caudal desenvolvido, aliado ao tamanho considerável atingido pela espécie, coloca essa raia como potencialmente perigosa para mergulhadores e pescadores, mas apenas se for molestada.

\section{Gênero Pteroplatytrygon}

Como principais características, seus representantes possuem margem anterior do disco convexa a reta, coloração escura tanto dorsal quanto ventralmente e tronco muito alto. Há apenas uma espécie: Pteroplatytrygon violacea.

Pteroplatytrygon violacea (Bonaparte, 1832) (Fig. 325)

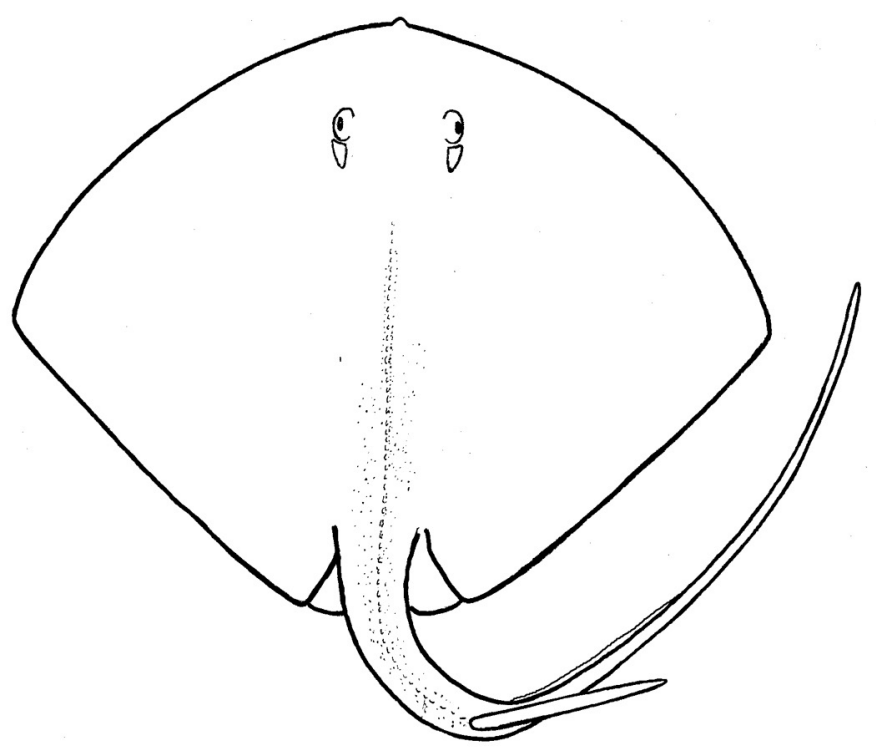

Nomes populares: raia-preta, raia-roxa, raia-pelágica. 
Caracteres distintivos: formato do disco trapezoidal; região anterior do focinho amplamente curva (arqueada), com um pequeno lobo apical pouco pronunciado; extremidade da nadadeira pélvica arredondada; apresenta linha mediana de tubérculos no tronco a partir de cerca de $30 \mathrm{~cm}$ de largura do disco; são verificados dentículos dispersos distribuídos aleatoriamente no dorso do disco, mas que não chegam a formar uma faixa semelhante a uma lixa, como em Hypanus guttatus. Linha de poucos (um a cinco) tubérculos na região escapular estão presentes (Fig. 318, seta E); apenas uma dobra ventral na caudal. A coloração da superfície dorsal do disco é uniformemente castanha escura, quase negra, com tons violáceos ou azulados; ventre escuro; os neonatos são caracteristicamente mais claros, no dorso e ventre.

Tamanho: cresce até cerca de $80 \mathrm{~cm}$ de $\mathrm{LD}$, com registros de animais com um metro de LD em cativeiro; maturidade sexual nos machos ocorre com cerca de 35 a $40 \mathrm{~cm}$ de LD e nas fêmeas, com cerca de 40 a 50 cm; tamanho ao nascer estimado de 15 a 25 cm de LD (esses dados são oriundos de animais em cativeiro).

Distribuição, Hábitos e Biologia: distribuição conhecida e esparsa nos oceanos do mundo inteiro. Essa raia se desloca com agilidade na coluna d'água, com hábitos usualmente oceânicos. Espécie epipelágica, encontrada ao largo de plataformas continentais e insulares. Ocasionalmente exemplares são coletados em pequenas profundidades, em áreas costeiras. Vivípara lecitotrófica, com suporte nutricional por trofonemata, produz de quatro a nove neonatos, depois de uma gestação estimada em quatro meses; tais dados também oriundos de animais em cativeiro. Alimentação consiste em celenterados (medusas), moluscos (lulas), crustáceos e pequenos peixes ósseos.

Observações: freqüentemente é capturada por espinhéis oceânicos ao largo de toda a costa brasileira, sendo normalmente descartada como produto da pesca.

\section{Família MOBULIDAE}

Representada por um gênero e 11 espécies, as raias dessa família são conhecidas popularmente como “jamantas”, chegando até sete metros de LD. Possuem projeções cefálicas pares anteriormente à cabeça, dando o aspecto de chifres (Fig. 326). Essa é uma das características mais marcantes e diagnósticas da família. A cabeça, tronco e nadadeiras peitorais são bastante largas, formando um disco romboidal, de extremidades pontiagudas, que é mais largo do que comprido. Cauda filamentosa curta ou longa, destacada do disco e dotada de uma nadadeira dorsal em sua base; ferrões serrilhados presentes ou ausentes. Boca reta e transversal, de posição subterminal ou terminal. Dentes pequenos e arranjados em várias séries, localizada em uma ou em ambas as arcadas. Pele lisa ou um pouco áspera, com alguns espinhos ou pequenos tubérculos. Vivem em águas tropicais de todos os oceanos, sobre plataformas continentais e insulares. São raias pelágicas e altamente migratórias. 
Alimentam-se de organismos zooplanctônicos e de cardumes de pequenos peixes. São vivíparas aplacentárias, de baixíssima fecundidade, gerando um filhote por parto. Estão entre os elasmobrânquios mais vulneráveis à mortalidade por ação antrópica, especialmente pela atividade da pesca. Mundialmente, algumas espécies se mostram importantes para o ecoturismo.

Eram conhecidos dois gêneros (Manta e Mobula). Muitos pesquisadores, intrigados com as limitações na classificação taxonômica destes gêneros, decidiram por investigar a possibilidade dessas espécies constituírem um mesmo gênero. Estudos de analise molecular em DNA mitocondrial demonstraram que há uma significativa relação de parentesco entre as espécies desse grupo. Finalmente, as espécies de Manta foram incluídas no gênero Mobula, continuando na família Mobulidae. Devido ao seu grande porte, poucos exemplares são depositados em coleções, dificultando as comparações dos indivíduos adultos.

Cinco espécies conhecidas no Rio de Janeiro: $M$. birostris, $M$. hypostoma, $M$. mobular, M. tarapacana e M. thurstoni.

\section{Gênero Mobula}

Boca bastante larga terminal ou subterminal com placa de dentes presente em ambas as arcadas ou apenas na arcada inferior; cabeça larga, bem desenvolvida, com lobos cefálicos proeminentes. Olhos e espiráculos posicionados lateralmente. Cauda em forma de chicote, variando desde longa até relativamente curta, sempre menor que a largura do disco. Possuem apenas uma nadadeira dorsal, e o ferrão pode estar presente.

\section{Chave para Identificação das Espécies do Gênero Mobula}

1a) Boca terminal inferior (Fig. 326); placa de dentes somente na arcada inferior.

Mobula birostris

1b) Boca subterminal inferior (Fig. 327); placa de dentes presente em ambas as arcadas

2

2a) Ferrão caudal ausente; disco estreito, sua largura correspondendo a menos de duas vezes o seu comprimento; cauda sem uma fileira de dentículos brancos de cada lado; nadadeira dorsal sem ápice branco

2b) Ferrão caudal presente; disco largo, correspondendo a duas vezes o seu comprimento; cauda com uma fileira de dentículos brancos de cada lado; nadadeira dorsal com ápice branco Mobula mobular

3a) Placas dentárias ocupam cerca de 69 a 70\% da largura da boca; placas filtradoras branquiais completamente fusionadas (Fig. 328). Mobula tarapacana 
3b) Placas dentárias ocupam menos de $65 \%$ ou mais de $72 \%$ da largura da boca; placas filtradoras branquiais completamente separadas (Fig. 329).

4a) Placas dentárias ocupam cerca de 50-65\% da largura da boca; base da cauda lateralmente comprimida; margem anterior da nadadeira peitoral reta ou levemente convexa (Fig. 330, setas).

Mobula hypostoma

4b) Placas dentárias ocupam de $72 \%$ a $76 \%$ da largura da boca; base da cauda dorsalmente comprimida; margem anterior da nadadeira peitoral levemente cavada próxima do seu ápice (Fig. 331, setas).

Mobula thurstoni

Mobula birostris (Walbaum, 1792) (Fig. 332)

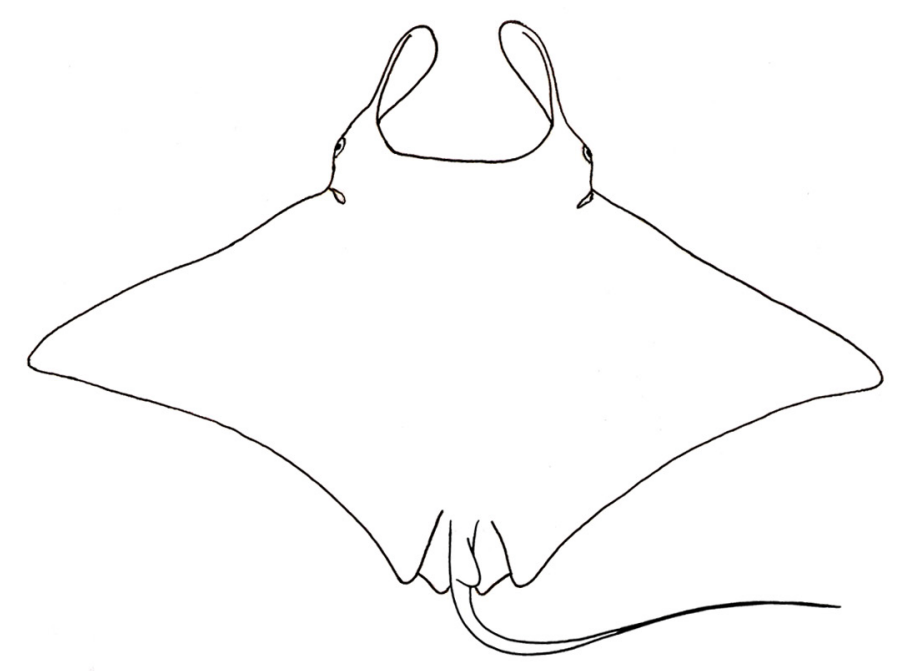

Nomes populares: manta, raia-jamanta.

Caracteres distintivos: coloração dorsal predominantemente escura, mas podendo variar de castanha avermelhada a preta, com pequenas pintas ou manchas presentes ocasionalmente; eventualmente manchas claras nucais de aspectos variados; parte ventral do corpo branca, podendo apresentar manchas cinzas e, ocasionalmente o ventre é predominantemente negro, com mancha branca na área branquial. Tamanho: a maior de todas as raias em envergadura, podendo atingir sete metros de LD, embora haja um registro de nove metros não confirmado; a maturidade em machos se dá entre 3,6 e 3, 8 m de LD e, em fêmeas, entre 3,8 e quatro metros; tamanho ao nascer estimado entre 1,1 e 1,3 $\mathrm{m}$ de LD.

Distribuição, Hábitos e Biologia: distribuição aparentemente mundial (se for considerado que representantes de algumas outras regiões sejam, na verdade, espécies diferentes). Ocorre no Oceano Atlântico ocidental, desde a Nova Inglaterra (nordeste dos EUA) até, pelo menos, o Sul do Brasil. Nadadora pelágica ativa, preferencialmente sobre a plataforma continental e ao redor de ilhas oceânicas, com ocasionais registros em áreas oceânicas abertas. Vivípara lecitotrófica, com suporte nutricional por trofonemata, dá a luz a apenas um filhote a cada gestação. A alimentação é constituída de organismos zooplanctônicos e peixes muito pequenos. Essa raia é conhecida por formar agrupamentos de numerosos indivíduos em regiões recifais 
durante o período de reprodução dos corais e de alta concentração de plâncton; a captura do alimento acontece através de golpes com sua enorme cavidade bucal, ingerindo grandes quantidades de água e filtrando os organismos em suas placas branquiais modificadas.

Observações: Mobula birostris apresenta comportamento dócil e curioso perante o homem, revelando, inclusive, alguma sociabilidade; são comuns os casos de mergulhadores nadando lado a lado ou mesmo cavalgando essas raias. Espécie muito procurada por operadoras de mergulho turístico em numerosas localidades do mundo; no Brasil o melhor ponto de mergulho para observação desta espécie é o Parque Estadual Marinho da Laje de Santos (SP), onde podem ser vistas principalmente no inverno. Registros do encontro desses animais ao largo de algumas ilhas do Rio de Janeiro podem se referir a essa espécie.

\section{Mobula mobular (Bonnaterre, 1788) (Fig. 333)}

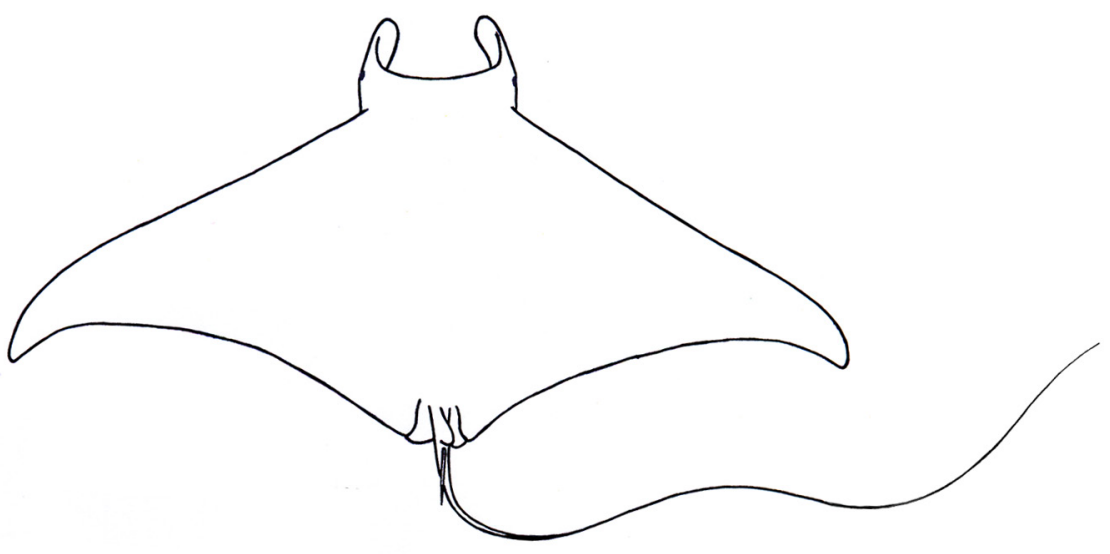

Nomes populares: raia-jamanta, raia-boca-de-gaveta.

Caracteres distintivos: possui disco muito largo (LD correspondente a duas vezes o CD); cauda longa, seu comprimento igual ou maior que a largura do disco, com ferrão e com uma fileira de dentículos brancos em cada lado; espiráculos elípticos e situados dorsalmente em relação ao plano de origem das nadadeiras peitorais; placas dentárias superior e inferior com comprimentos semelhantes (aproximadamente 75\% e $76 \%$ da largura da boca, respectivamente); dentes pequenos com cúspide pouco destacadas; lobos terminais das placas branquiais filtradoras lanceolados e separados entre si. Coloração azulada escura no dorso; exemplares pequenos com um par de manchas claras simétricas em forma de crescente na região dorsal próximas da cabeça, padrão que tende a ficar menos evidente ou desaparecer em adultos; nadadeira dorsal com ápice branco; superfície ventral uniformemente branca em exemplares pequenos, mas com o crescimento normalmente aparecem manchas escuras acinzentadas.

Tamanho: largura máxima do disco cerca de 3,1 m; maturidade sexual nos machos se dá com cerca de 1,9 a 2,1 m de LD e nas fêmeas, supostamente, a partir de 2,6 a 2,7 $\mathrm{m}$; nascem com cerca de 85 a $92 \mathrm{~cm}$ de LD. 
Distribuição, Hábitos e Biologia: encontra-se nos oceanos Pacífico oriental, IndoPacífico, Atlântico ocidental e oriental. Ocorre em áreas oceânicas e costeiras em menor abundância. No Brasil, registros pontuais confirmados para o Nordeste, Sudeste e Sul. Vivípara lecitotrófica, com suporte nutricional por trofonemata, parindo apenas um filhote a cada gestação. Dentre as raias-manta, parece ser a mais solitária, pois quase nunca é encontrada em cardumes. Acredita-se que sua ocorrência também esteja associada a áreas ricas em plâncton. Como todos os Mobulidae, alimenta-se de organismos zooplanctônicos e eventualmente de peixes muito pequenos.

Observações: até recentemente essa espécie não era conhecida como habitante do Oceano Atlântico ocidental, mas possivelmente isso se deve ao fato de que, a exemplo do que ocorre com outras espécies do gênero, sua identificação não era feita de forma adequada em estudos pretéritos. Anteriormente essa espécie era conhecida como Mobula japanica.

Mobula tarapacana (Philippi, 1893) (Fig. 334)

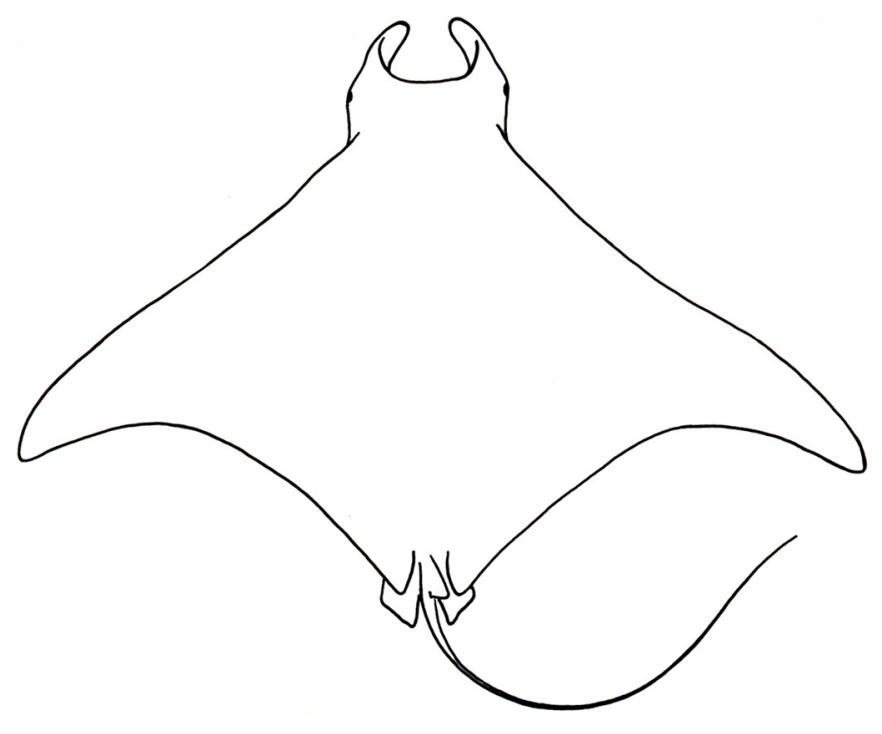

Nomes populares: raia-jamanta, raia-boca-de-gaveta.

Caracteres distintivos: disco menos largo e mais longo, com a LD correspondendo a menos do que duas vezes o seu CD; cauda sem ferrão, relativamente curta (seu comprimento é bem menor do que a largura do disco) e sem uma fileira de dentículos brancos em cada lado; espiráculos elípticos e situados dorsalmente em relação ao plano em que se situa a origem das nadadeiras peitorais; placas dentárias com 69\%$70 \%$ da largura da boca; placas filtradoras dos arcos branquiais completamente fusionadas; dentes pequenos sem cúspides destacadas, com coroa hexagonal em vista dorsal; lobos terminais das placas filtradoras dos arcos branquiais são lanceolados e fundidos entre si. Coloração dorsal escura de tonalidade cinza olivácea; nadadeira dorsal sem mancha branca no seu ápice; superfície ventral do corpo clara, branca, 
com margem posterior da nadadeira peitoral cinza-claro. Normalmente com mancha mais escura próxima das axilas de cada nadadeira peitoral.

Tamanho: cresce até cerca de 3,3 m de LD; maturidade sexual dos machos em torno de 2,3 e 2,5 m, e nas fêmeas se dá entre 2,7 e 2,8 m de LD; nasce com aproximadamente um a $1,3 \mathrm{~m}$ de LD.

Distribuição, Hábitos e Biologia: encontra-se em área costeiras e oceânicas de todo o mundo, principalmente nas zonas tropicais e subtropicais. Ocorre no Oceano Atlântico ocidental, com registros para Venezuela, Golfo do México e Brasil (Norte e Nordeste em ilhas e bancos oceânicos; Arquipélago de Fernando de Noronha; no Banco Rodger próximo ao Arquipélago de Abrolhos - BA; no Arquipélago de São Pedro e São Paulo - PE; na Laje de Santos - SP; na plataforma continental paulista, que é o limite sul de sua distribuição). Vivípara lecitotrófica, com suporte nutricional por trofonemata, parindo apenas um filhote a cada gestação. Pode ser encontrada solitariamente ou em agrupamentos de dezenas de exemplares, que se reúnem em áreas ricas em organismos zooplanctônicos.

Observações: até recentemente essa espécie não era conhecida como habitante do Oceano Atlântico Sul ocidental, mas possivelmente isso se deve ao fato de que, a exemplo do que ocorre com outras espécies do gênero, sua identificação não era feita de forma adequada em estudos anteriores. Erroneamente, foi identificada como Mobula hypostoma ou Manta birostris em alguns estudos prévios (White et al., 2018). Assim como Mobula mobular, deve ocorrer ao longo de toda a costa brasileira, porém associada a acidentes geográficos emersos e oceanográficos como Arquipélago de São Pedro e São Paulo no Nordeste, ou bancos oceânicos no Nordeste, ou Laje de Santos - São Paulo, no Sudeste do Brasil.

Mobula hypostoma (Bancroft, 1831) (Fig. 335)

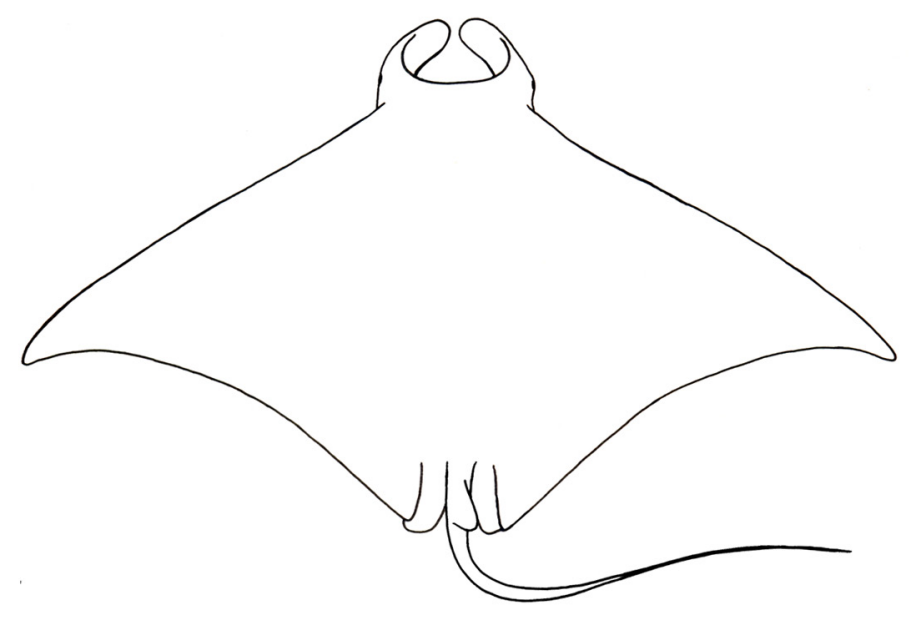

Nomes populares: raia-jamanta, jamanta-mirim, raia-boca-de-gaveta.

Caracteres distintivos: disco largo e relativamente curto, com o CD correspondendo a cerca da metade da LD; sem ferrão caudal; cauda relativamente curta, menor do 
que a LD, e comprimida lateralmente; placas dentárias ocupam menos de 50\%-65\% da largura da boca; possui dimorfismo sexual dentário bastante evidente. Coloração dorsal escura azulada ou esverdeada, sem qualquer mancha mais clara retangular na cabeça; nadadeira dorsal sem mancha branca no seu ápice; ventre claro, em tons creme ou branco, podendo exibir margens mais escurecidas nas margens das nadadeiras peitorais.

Tamanho: maturação de machos e fêmeas aos 1,14 m e 1,11 m de LD respectivamente; filhotes nascem com $55 \mathrm{~cm}$ de LD.

Distribuição, Hábitos e Biologia: regular em águas costeiras do Oceano Atlântico Ocidental tropical e subtropical, incluindo Rhode Island e North Carolina (EUA), Golfo do México, Mar do Caribe, costa da América do Sul até Mar del Plata (Argentina). É pelágica em águas costeiras. Vivípara lecitotrófica, com suporte adicional por trofonemata, parindo apenas um filhote a cada gestação. Pode ser encontrada solitariamente ou grupos de dezenas de indivíduos, que normalmente se agregam em áreas ricas em plâncton. Sua alimentação é constituída principalmente de organismos do zooplâncton e, eventualmente, de pequenos peixes.

Observações: seus registros no Atlântico Oriental são possivelmente erros de identificação, e corresponderiam a Mobula rochebrunei, porém este nome caiu em desuso, sendo um sinônimo de $M$. hypostoma. Vários registros de M. hypostoma ao longo da costa brasileira referem-se, na verdade, a $M$. mobular, $M$. tarapacana e $M$. thrustoni, o que dificulta o conhecimento sobre a área de distribuição dessas espécies no litoral brasileiro.

Mobula thurstoni (Lloyd, 1908) (Fig. 336)

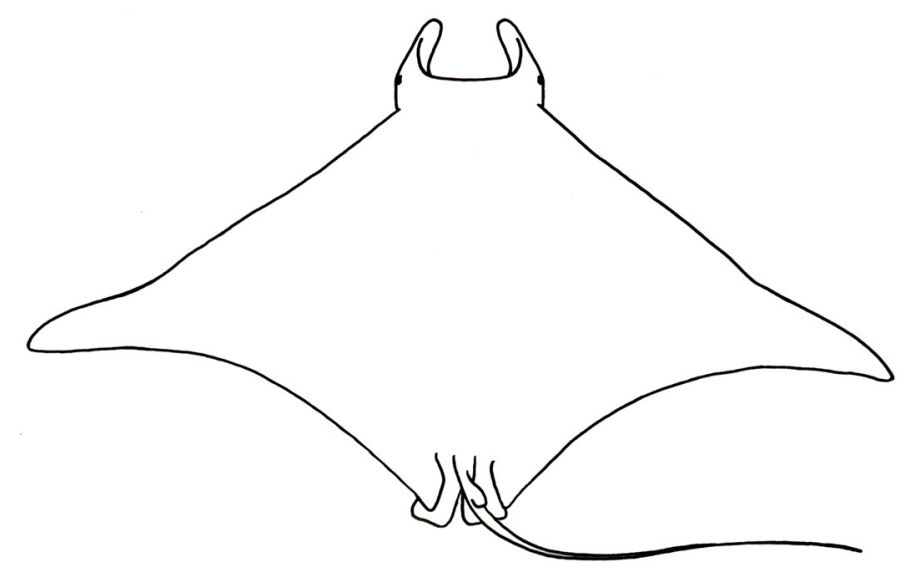

Nomes populares: raia-jamanta; raia-boca-de-gaveta.

Caracteres distintivos: disco largo e curto, sendo que seu CD corresponde a cerca da metade da LD; cauda relativamente curta, menor do que a LD, sem ferrão serrilhado em sua base; presença de mancha branca no canto da margem anterior das nadadeiras peitorais próxima ao ápice; base da cauda deprimida dorsalmente; margem anterior das peitorais côncavas perto da sua extremidade; espiráculo 
subcircular, localizado ventralmente ao plano da origem das nadadeiras peitorais; placas dentárias ocupam de $72 \%$ a $76 \%$ da largura da boca. Coloração azulada escura na superfície dorsal, com manchas roxas; área retangular cinza clara na região nucal; apresenta uma área subtriangular estreita bronzeada ao longo da margem anterior das nadadeiras peitorais, extremidade da nadadeira dorsal com mancha branca; superfície ventral do disco branca, usualmente com margens das peitorais escuras em exemplares menores.

Tamanho: LD máxima conhecida cerca de 1,9 m; machos maduros entre 1,3 e 1,5 m, e fêmeas, supostamente a partir de 1,5 m de LD; filhotes nascem medindo entre $65 \mathrm{e}$ $85 \mathrm{~cm}$ de LD.

Distribuição, Hábitos e Biologia: provavelmente se distribui circunglobalmente. Espécie de hábito costeiro e oceânico, de áreas tropicais até subtropicais. Sua ocorrência e distribuição no Sudeste brasileiro está associada à penetração de águas ricas em plâncton na faixa costeira durante o verão. Nesse período, exemplares adultos são avistados nessa área até o inverno, quando se afastam da costa. Vivípara lecitotrófica, com suporte nutricional por trofonemata, parindo apenas um filhote a cada gestação. Vive solitária ou em grupos de dezenas de indivíduos, principalmente em áreas ricas de seu principal alimento, organismos do zooplâncton e eventualmente pequenos peixes.

Observações: à exemplo do que foi constatado para as outras espécies do gênero Mobula, trabalhos anteriores cometeram alguns equívocos na identificação desses animais, resultando em um quadro de conhecimento inadequado sobre a composição da fauna brasileira.

\section{Família RHINOPTERIDAE}

Raias de tamanho moderado a grande; LD de até dois metros; disco em formato de losango ou romboidal; visivelmente mais largo que comprido. Cabeça destacada do contorno da nadadeira peitoral e com profundo entalhe na extremidade mediana anterior (Fig. 305-seta e Fig. 339). Olhos e espiráculos na lateral da cabeça. Boca aproximadamente transversa; papilas ausentes no chão da boca. Lobo anterior das narinas expandido posteriormente formando as cortinas nasais, com margem posterior franjeada. Nadadeiras peitorais falciformes, originando-se na parte dorsal da cabeça, posterior às órbitas, e com extremidades agudas. Uma nadadeira dorsal pequena localizada na base da cauda; cauda filamentosa, bem destacada do disco e acompanhada de um ferrão (raramente mais do que isso) retroserrilhado localizado imediatamente após a nadadeira dorsal. Pele toda lisa ou áspera, com dentículos na superfície dorsal e na linha mediana do corpo. Seus representantes habitam plataformas continentais e insulares tropicais e temperadas em todo o mundo. Nadam ativamente e são capazes de migrar por longas distâncias. Ocasionalmente, observam-se na superfície e saltando fora d'água, porém geralmente nadam próximo 
ao fundo em pequenos grupos. Podem formar agregações gigantescas de centenas ou milhares de indivíduos. Foram vistos cardumes sendo atacados por orcas (Orcinus orca) próximos às praias da Zona Sul do Estado do Rio de Janeiro.

Grupo de morfologia externa muito similar e, consequentemente, identificação bastante difícil. É representado apenas por uma família e um gênero em todo o mundo (Rhinoptera), com oito espécies. No Brasil ocorrem duas espécies, ambas registradas no Estado do Rio de Janeiro.

\section{Gênero Rhinoptera}

A descrição da família é suficiente para identificação do único gênero conhecido: dentes pavimentosos constituídos de placas lisas dispostas em seis a dez séries; aquelas pertencentes à coluna mediana são maiores. Das espécies, oito conhecidas, e duas foram registradas no Brasil (Rhinoptera bonasus e Rhinoptera brasiliensis), ambas na costa do Estado do Rio de Janeiro.

\section{Chave para Identificação das Espécies do Gênero Rhinoptera}

1a. Normalmente sete fileiras de dentes superiores e inferiores (ocasionalmente seis ou oito); a fileira central é mais larga que as duas fileiras paralelas adjacentes (cerca de duas vezes mais larga) (Fig. 337)

Rhinoptera bonasus

1b. Normalmente nove fileiras de dentes superiores e inferiores (ocasionalmente oito ou dez); fileira central de largura similar ou pouco maior que as duas fileiras paralelas adjacentes (menos de duas vezes mais larga) (Fig. 338)

Rhinoptera brasiliensis

Rhinoptera bonasus (Mitchill, 1815) (Fig. 339)

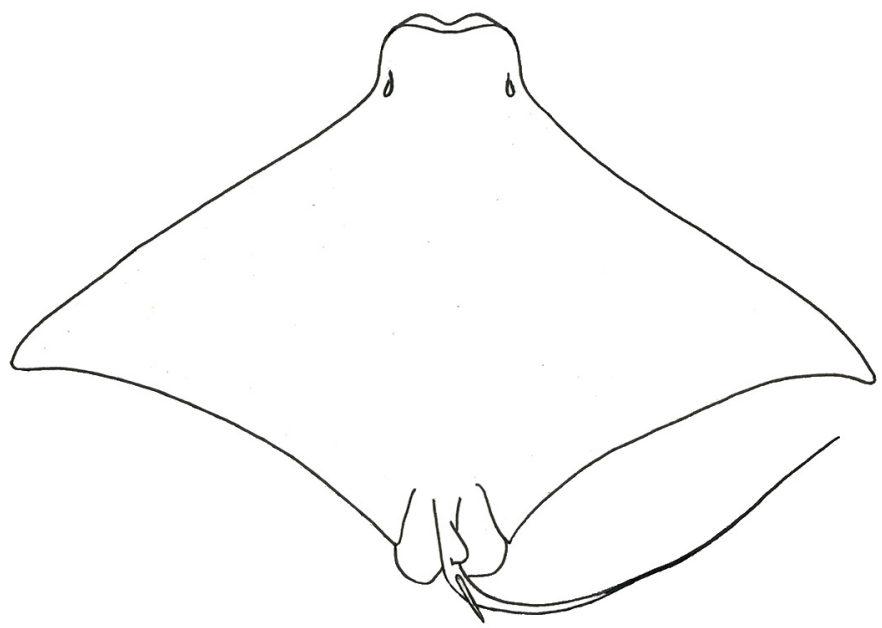

Nomes populares: ticonha, raia-manteiga. 
Caracteres distintivos: difícil a separação dessa espécie de sua congênere, $R$. brasiliensis, com utilização de outras características que não o número e largura relativa das placas dentárias. De uma forma geral, essa espécie pode também ser identificada observando-se a morfologia geral do entalhe mediano dos lobos cefálicos, que é relativamente mais profundo e cada ápice do lobo é mais agudo, alongando-se além da reta vertical que passa no nível da ponta da cabeça; a parte cefálica anterior dorsal tem um entalhe mediano relativamente mais raso e de angulação mais aberta; distância interorbital corresponde de $21,8 \%$ a $29,7 \%$ da LD e a distância internasal de $5,8 \%$ a $7,1 \%$ da LD. Dorsalmente a coloração do disco é castanha uniforme, e a superfície ventral varia de branca a amarelada.

Tamanho: cresce até cerca de 1,1 m de LD; maturidade sexual nos machos entre 70 a $80 \mathrm{~cm}$ de LD, e entre 65 e $90 \mathrm{~cm}$ nas fêmeas; nascem medindo entre 30 e $40 \mathrm{~cm}$ de LD.

Distribuição, Hábitos e Biologia: distribui-se pelo Oceano Atlântico ocidental; registros do sul da Nova Inglaterra ao norte da Argentina, incluindo Golfo do México e Cuba até, pelo menos o Estado do Paraná. São raias costeiras, de hábitos bentônicos e pelágicos. Há registros de grandes cardumes, possivelmente em rota migratória, observados em águas mais afastadas da costa. Vivípara lecitotrófica, com suporte nutricional por trofonemata, parindo um filhote a cada gestação (embora haja registro de até seis embriões em uma fêmea). Alimenta-se de moluscos de concha dura e de crustáceos, que são esmagados pela dentição pavimentosa.

Observações: durante muito tempo essa espécie foi considerada a única no Oceano Atlântico ocidental, de modo que muitas informações da costa brasileira devem se referir, na verdade, a $R$. brasiliensis. Milhares de exemplares capturados em redesde-arrasto-de-praia no Estado do Rio Grande do Sul na década de 1980 e referidos como essa espécie tratavam-se, na verdade, de $R$. brasiliensis. Essa confusão causou alguns problemas para o entendimento de vários aspectos da biologia e distribuição de Rhinoptera no Oceano Atlântico Sul ocidental. Parece ser menos comum no Sudeste e Sul do que sua congênere. As capturas de Rhinoptera ao longo da costa Norte e Nordeste devem ser analisadas com mais atenção, de modo a identificar corretamente a espécie, e conhecer a extensão da área de distribuição de $R$. bonasus no Oceano Atlântico Sul ocidental. 


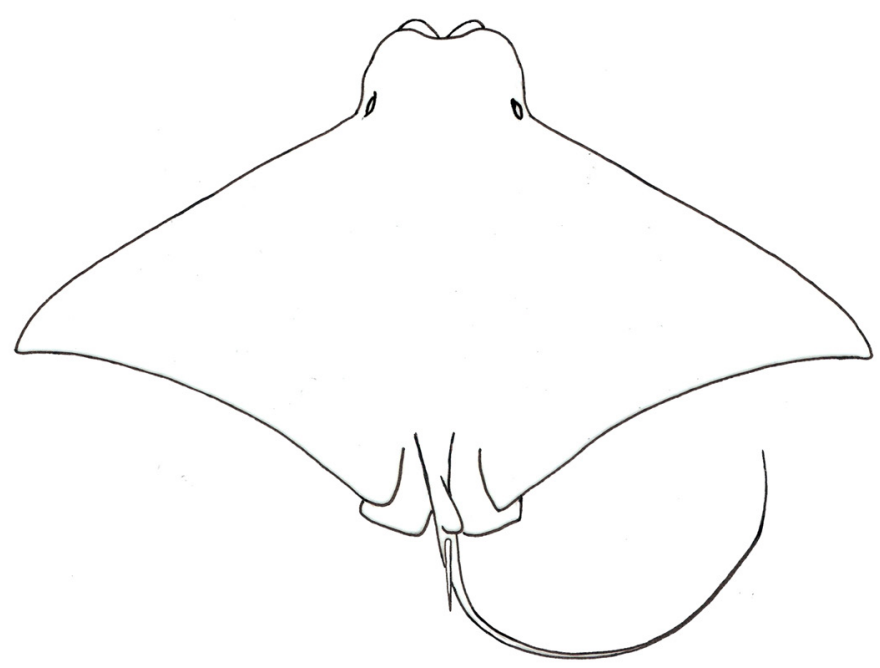

Nomes populares: ticonha, raia-manteiga.

Caracteres distintivos: Como foi descrito para $R$. bonasus, a diferenciação primária entre essas espécies se faz basicamente através da morfologia das placas dentárias. De uma forma geral, essa espécie pode ser identificada observando-se também a morfologia geral do entalhe mediano dos lobos cefálicos, que é relativamente mais raso e cada ápice do lobo é menos agudo, não se alongando além da reta vertical que passa no nível da ponta da cabeça; a parte cefálica anterior dorsal tem um entalhe mediano relativamente mais profundo e de angulação mais fechada; a distância interorbital corresponde de $15,7 \%$ a 17,8\% da largura do disco e a distância internasal de $8 \%$ a $8,5 \%$ da LD. Coloração muito semelhante à da espécie anterior, com superfície dorsal uniformemente castanha e ventral amarelada ou branca; ventralmente, as margens do disco podem ser mais escuras.

Tamanho: cresce até cerca de 1,1 $\mathrm{m}$ de LD; dados sobre o tamanho da maturidade sexual não são conhecidos, mas supostamente similar a $R$. bonasus.

Distribuição, Hábitos e Biologia: ocorre no Oceano Atlântico ocidental, registrada na Carolina do Norte, sudoeste do Golfo do México, costa caribenha da Colômbia e Oceano Atlântico Sul ocidental brasileiro. Costeira, tanto bentônica como pelágica, com registro de grandes agregações migratórias ao largo da costa. No Sul do Brasil faz migrações de verão para áreas costeiras. Essa espécie é vivípara lecitotrófica, com suporte nutricional por trofonemata, parindo um filhote a cada gestação. Alimentase de moluscos de concha dura e crustáceos.

Observações: durante muito tempo essa espécie foi considerada inválida e apenas $R$. bonasus era aceita como a única no Oceano Atlântico ocidental, de modo que as informações para a costa brasileira, e que se referem $R$. brasiliensis, aparecem sob o nome de $R$. bonasus. Tal fato causou alguns problemas para o entendimento de vários aspectos da biologia e distribuição de Rhinoptera no Atlântico Sul ocidental. 


\section{Família MYLIOBATIDAE}

Raias de tamanho moderado a grande, com LD atingindo até cerca de três metros. Cabeça destacada do disco e terminando em lobo carnoso frontal único, curto ou moderadamente longo, mais ou menos pontiagudo, resultante ou não da convergência da margem anterior de cada nadadeira peitoral. Olhos e espiráculos na lateral da cabeça. Boca reta a levemente arqueada com a presença de várias papilas. Dentes pavimentosos arranjados de uma até sete séries. Cortinas nasais bem desenvolvidas, com margem posterior livre sobrepondo-se à boca. Tronco e nadadeiras peitorais largamente expandidas, de extremidades angulosas, compondo um disco de formato romboidal. Cauda filamentosa, distintamente demarcada do disco, com uma pequena nadadeira dorsal em sua base e com um ou mais ferrões retro-serrilhados. Olhos e espiráculos na lateral da cabeça. Superfície dorsal lisa ou com tubérculos em torno das órbitas, ao longo do dorso e, às vezes, também na cauda. Superfície ventral lisa. São raias de regiões tropicais ou temperadas do mundo inteiro. Normalmente associadas às regiões costeiras ou plataformas insulares de áreas oceânicas. Nadam através de movimentos oscilatórios verticais das nadadeiras peitorais. Algumas espécies podem realizar migrações de longas distâncias. Constantemente, são observadas nadando próximas à superfície e, ocasionalmente, saltam completamente fora d'água. Entretanto geralmente nadam em grupos próximos ao fundo. No mundo são conhecidos dois gêneros: Aetomylaeus (com sete espécies) e Myliobatis (com 11 espécies). No Brasil, ocorre apenas o gênero Myliobatis e três espécies: $M$. freminvillei, $M$. goodei e $M$. ridens; as duas primeiras ocorrem na costa do Estado do Rio de Janeiro.

\section{Gênero Myliobatis}

Caracterizam-se por apresentar mais de uma série (normalmente sete) de dentes em cada arcada dentária; os dentes das séries medianas são bem mais largos que os das fileiras adjacentes.

\section{Chave para Identificação das Espécies do Gênero Myliobatis}

1a. Distância da margem posterior das nadadeiras pélvicas até a origem da nadadeira dorsal é aproximadamente igual ao comprimento da base da nadadeira dorsal (Fig. 341); machos maduros com tubérculos sobre cada órbita (Fig. 342)

Myliobatis freminvillei

1b. Distância da margem posterior das nadadeiras pélvicas até a origem da nadadeira dorsal é de duas a três vezes maior do que o comprimento da base da nadadeira 
dorsal (Fig. 343); machos maduros sem tubérculos sobre cada órbita (Fig. 344).

Myliobatis goodei

Myliobatis freminvillei Lesueur, 1824 (Fig. 345)

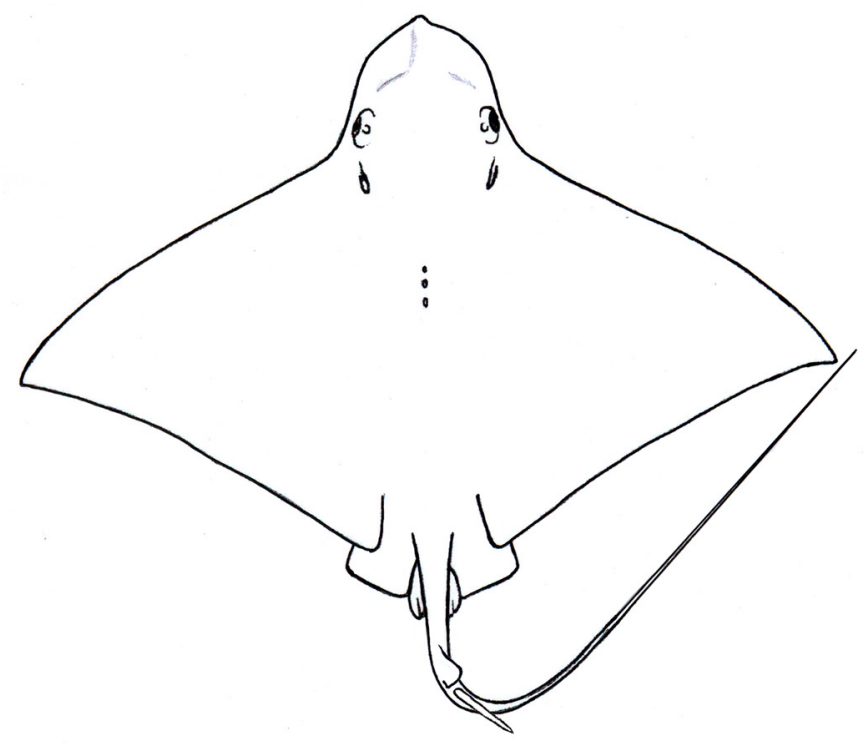

Nome popular: raia-sapo.

Caracteres distintivos: focinho relativamente mais longo que em M. goodei; distância pré-orbital inferior de sete a 10\% da LD; distância entre o último par de fendas branquiais é relativamente menor, correspondendo de o,9 a 1,2 vezes da distância internasal e de o,7 a uma vez da largura da boca; adultos com tubérculos em fileira mediana na região escapular; Nos machos adultos, acrescenta-se um tubérculo em cima de cada órbita. Coloração do dorso: superfície dorsal castanha acinzentada, avermelhada ou escura, podendo apresentar manchas esbranquiçadas e, geralmente, menores que o diâmetro dos olhos; superfície ventral branca; nadadeira dorsal ocasionalmente mais clara; parte posterior da cauda castanha a preta.

Tamanho: LD máxima de cerca de $85 \mathrm{~cm}$; maturação de machos a partir de $45 \mathrm{~cm}$, e fêmeas a partir de $58 \mathrm{~cm}$ de LD; recém-nascidos medem entre 22 a $23 \mathrm{~cm}$ de LD.

Distribuição, Hábitos e Biologia: ocorre desde Cape Cod (EUA) ao sul do Brasil, Uruguai e norte da Argentina; também presente no Golfo do México, porém ausente nas Antilhas e Bahamas. Encontrada com maior frequência em águas costeiras até 100 $\mathrm{m}$ de profundidade. Efetua longos deslocamentos migratórios. Essa espécie é vivípara lecitotrófica, com presença de trofonemata como suporte adicional de nutrientes. Produz uma média de três a quatro embriões por gestação. Alimenta-se de moluscos (bivalves e gastrópodes) e crustáceos (lagostas e caranguejos), triturados por sua dentição pavimentosa.

Observações: Os aspectos morfológicos e morfométricos do crânio, bem como a dentição e parâmetros reprodutivos de M. freminvillei do Sudeste e Sul do Brasil diferem consideravelmente de exemplares do Oceano Atlântico Norte ocidental, o 
que sugere o fato de que se trate de uma espécie ainda não descrita. Mais abundante no período de inverno no Sul do Brasil.

Myliobatis goodei Garman, 1885 (Fig. 346)

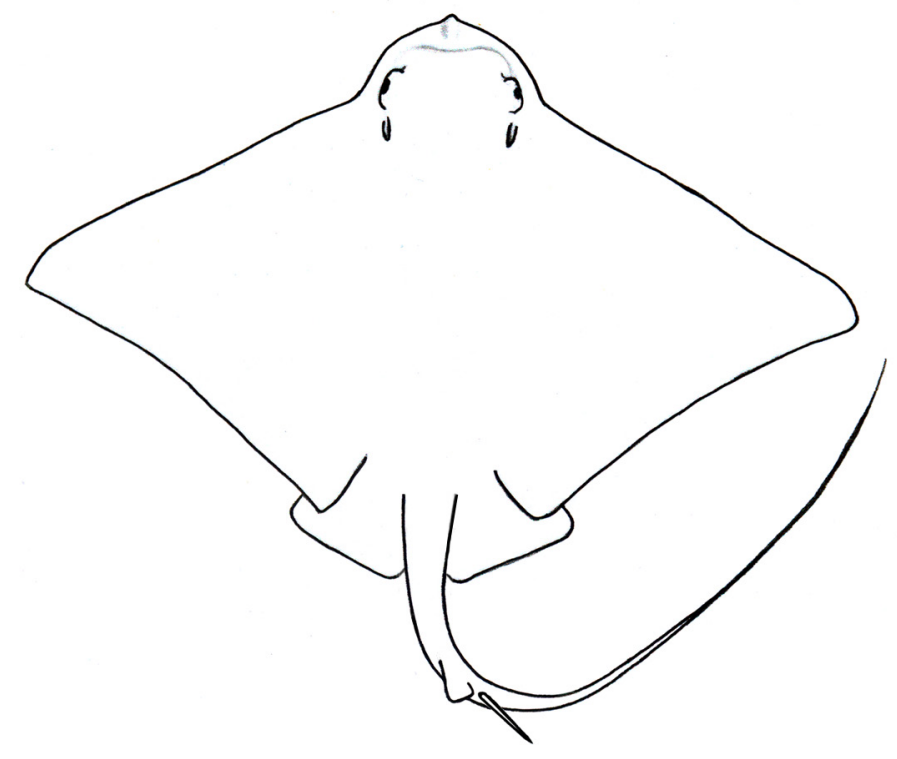

Nome popular: raia-sapo.

Caracteres distintivos: focinho relativamente mais curto que em $M$. freminvillei; distância pré-orbital inferior a $7 \%$ da LD; distância entre o último par de fendas branquiais é relativamente maior nessa espécie, correspondendo de 1,4 a 1,6 vezes a distância internasal e de 1,1 a 1,6 vezes a largura da boca; adultos sem tubérculos em fileira mediana na região escapular ou mesmo sobre os olhos em exemplares de qualquer tamanho. Coloração dorsal castanha chocolate a castanha acinzentada; ventre branco com margens externas do disco escuras.

Tamanho: LD máxima do disco de cerca de um metro; maturidade sexual nos machos a partir de $45 \mathrm{~cm}$ e nas fêmeas com cerca de $70 \mathrm{~cm}$ de LD; tamanho ao nascer em torno de 20 a $23 \mathrm{~cm}$ de LD.

Distribuição, Hábitos e Biologia: registrada desde Carolina do Norte ao sul da Flórida (EUA), Caribe na América Central, e do norte do Brasil ao norte da Argentina. Hábitos bentônicos a epipelágicos em águas costeiras até cerca de $100 \mathrm{~m}$ de profundidade na maioria das vezes. Efetua deslocamentos migratórios em grupos numerosos. Vivípara lecitotrófica, com suporte adicional de trofonemata, produz de quatro a seis embriões por gestação. A alimentação consiste em crustáceos e moluscos bivalves, triturados por ação de sua dentição pavimentosa. Essas raias são mais abundantes nos períodos de verão e inverno no sul do Brasil.

Observações: a citação de Myliobatis aquila (espécie da Europa) para o litoral do sudeste e sul do Brasil é um equívoco, e possivelmente se refere a Myliobatis goodei. 


\section{Família AETOBATIDAE}

São raias de grande porte alcançando até três metros de largura do disco, alguns indivíduos pesando cerca de 300 quilos. O corpo é bastante semelhante aos representantes da família Myliobatidae (outrora pertencentes a esta família). Possuem o focinho pronunciado e com nadadeiras peitorais desenvolvidas e pontiagudas em suas extremidades. Uma única série de dentes em ambas as arcadas é composta por várias fileiras dentárias. Há um espinho serrilhado na base da cauda em formato de chicote. A cortina nasal Tem um entalhe em sua porção mediana. São raias pelágicas, habitando mares tropicais e subtropicais. São vivíparas, podendo dar a luz a até dez filhotes. As cinco ou seis espécies conhecidas pertencem ao único gênero, Aetobatus. No Brasil apenas a espécies Aetobatus narinari é conhecida.

\section{Gênero Aetobatus}

Caracteriza-se por uma única série de dentes em cada arcada dentária e por apresentar a superfície dorsal cinza, cinza oliva ou castanha com manchas esbranquiçadas, amareladas ou azuladas, variando em tamanho e formato (redondas, elípticas ou anelares). Possui apenas uma espécie no Brasil (incluindo o Rio de Janeiro), Aetobatus narinari, conhecida como "raia-chita", possivelmente pelas manchas semelhantes ao felino guepardo ou chita (Acinonyx jubatus).

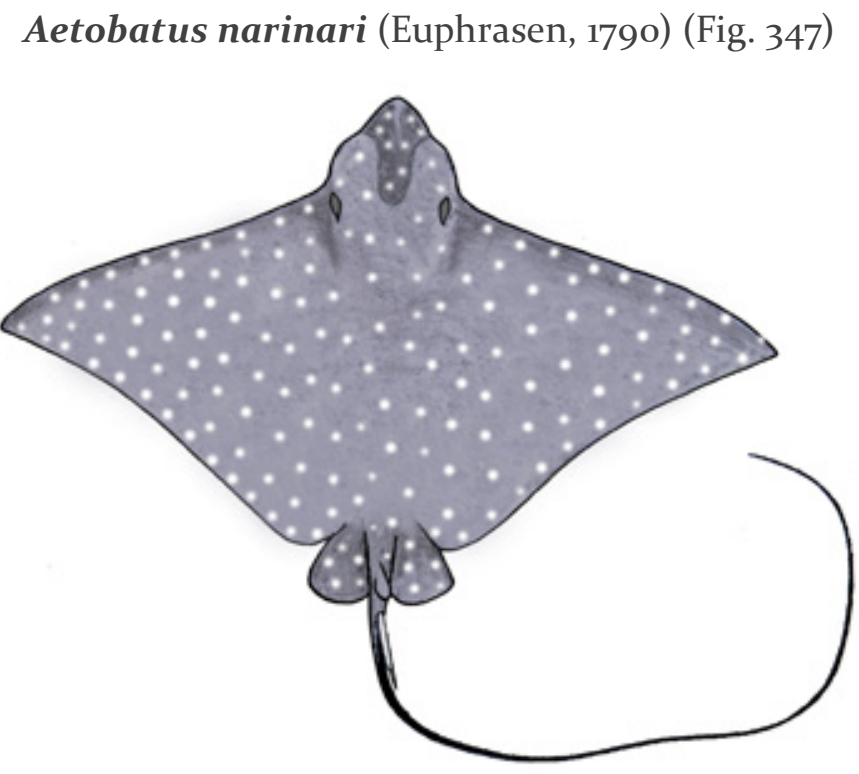

Nomes populares: raia-chita, raia-pintada.

Caracteres distintivos: disco largo, e curto, com comprimento do disco pouco menor do que metade da sua largura. Nadadeiras peitorais com extremidades angulares e margem posterior côncava. Cabeça destacada e elevada do disco, com a ponta do 
focinho terminando em lobo carnoso, levemente arredondado e moderadamente curto, e que não é contínuo com as margens anteriores das nadadeiras peitorais. Boca ventral, como lobo nasal em forma de "V" invertido. Dentes achatados e dispostos em única fileira, os superiores mais retos e os inferiores em forma de "V", não tão pronunciado. Cauda afilada e muito longa, seu comprimento (se não estiver danificada) corresponde de 2,5 a três vezes a LD. Coloração dorsal característica, com fundo castanho ou oliváceo escuro, recoberto uniformemente por numerosas pintas brancas ou outras mais fracas azuladas nas bordas das nadadeiras; bordas das nadadeiras peitorais e pélvicas, bem como a cauda, são mais escuras; coloração ventral branca.

Tamanho: LD máxima de cerca de $3,3 \mathrm{~m}$; com a longa cauda esticada, grandes exemplares podem alcançar quase nove metros de comprimento (incluída a longa cauda esticada); maturidade sexual nos machos a partir de aproximadamente $80 \mathrm{~cm}$ até $1,1 \mathrm{~m}$, e tais dados não são precisos para fêmeas. Nascem com cerca de 17 a $39 \mathrm{~cm}$ de largura de disco.

Distribuição, Hábitos e Biologia: conhecida no mundo inteiro, principalmente em águas tropicais e subtropicais. No Oceano Atlântico ocidental é conhecida desde a Carolina do Norte (EUA) até o Sul do Brasil. Apesar do modo de vida mais pelágico, essas grandes nadadoras comumente fazem incursões junto ao fundo, buscando alimentos. Chegam a dar saltos fora d'água. Pode ser encontrada solitariamente ou em grupos de dezenas de indivíduos. Essa espécie é vivípara lecitotrófica, com suporte nutricional também por trofonemata. Dão a luz a até quatro embriões por vez. A alimentação é constituída de pequenos invertebrados bentônicos, sobretudo moluscos bivalves, que são esmagados com as placas dentárias dessas raias. Também se alimentam de crustáceos e pequenos peixes. Para a captura do alimento, esses peixes revolvem o substrato com auxílio de seu lobo cefálico carnoso.

Observações: apesar de sua distribuição global, há variações nos padrões de coloração, morfológicos, biológicos e mesmo de fauna parasitária do intestino, que sugerem um complexo de, pelo menos, quatro espécies.

\section{AS QUIMERAS DO RIO DE JANEIRO}

Para a costa do Estado do Rio de Janeiro, apenas quatro espécies de quimeras são registradas até o momento: Callorhinchus callorhychus (Callorhynchidae), Hydrolagus alberti, Hydrolagus matallanasi (Chimaeridae) e Rhinochimaera atlantica (Rhinochimaeridae). No Brasil, além dessas espécies supracitadas, existe o registro de Hariotta raleighama (Rhinochimaeridae) na região Sul. Possivelmente mais espécies devam ser inventariadas e acrescentadas à ictiofauna marinha brasileira.

\section{Chave para a identificação das famílias (gêneros e espécies) da subclasse}




\section{Holocephali}

1a. Focinho alongado e pontiagudo

Rhinochimaeridae (Rhinochimaera atlantica) (Fig. 348)

1b. Focinho curto, rômbico ou cônico.

2a. Focinho com probóscide; nadadeira anal presente; nadadeira caudal heterocerca epicerca (com o lobo superior mais desenvolvido que o lobo inferior); macho com clasper não bifurcado.......Callorhynchidae (Callorhinchus callorhynchus) (Fig. 349) 2b. Focinho sem probóscide; nadadeira anal ausente; nadadeira caudal reta, terminando em um filamento; macho com clasper bifurcado

.Chimaeridae (Hydrolagus) (Figs.350 e 351)

\section{Chave para a identificação das espécies do gênero Hydrolagus}

1a- Corpo com coloração escura nas regiões dorsal e ventral e nadadeiras; margem da segunda nadadeira dorsal reta.

Hydrolagus alberti (Fig. 350)

2b- Corpo com coloração irregular, com reticulações e manchas claras; superfície ventral do corpo e nadadeiras esbranquiçadas; margem da segunda nadadeira dorsal ondulada.

Hydrolagus matallanasi (Fig. 351)

Rhinochimaera atlantica Holt \& Buyrne, 1909 (Fig. 348)

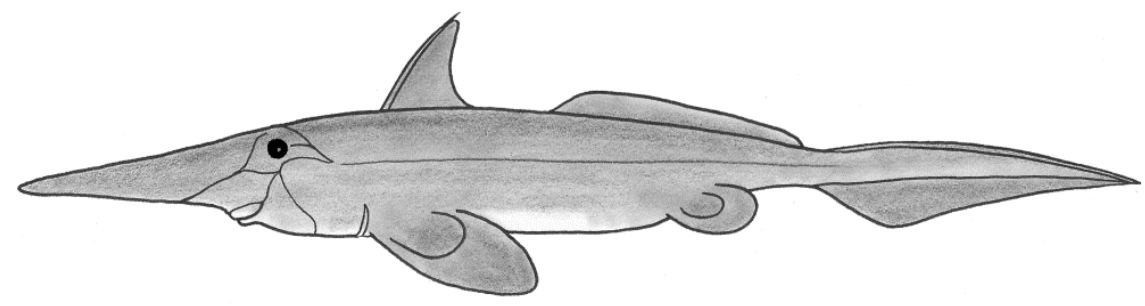

Nomes populares: quimera focinhuda.

Caracteres distintivos: Focinho alongado e comprimido; região caudal afilando, terminando em um filamento. Nadadeiras peitorais e pélvicas largas. Coloração acinzentada ou marrom, geralmente com o ventre claro ou esbranquiçado.

Tamanho: Atinge o comprimento total de 1,5 metros, e o comprimento do corpo, sem o filamento caudal, $65 \mathrm{~cm}$.

Distribuição, Hábitos e Biologia: Até então, essa espécie era registrada para o Golfo do México, Suriname e Guiana Francesa. Recentemente sua presença foi registrada para a Bacia de Campos, RJ, sendo então a primeira ocorrência dessa espécie para o Brasil.

Provavelmente se alimenta de pequenos invertebrados. São encontrados em profundidades entre 400 e 1800 metros. 


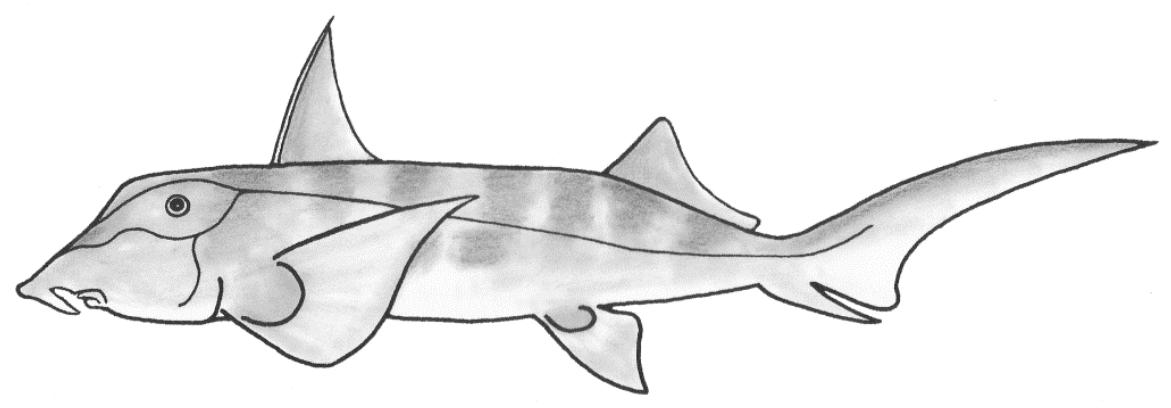

Nomes populares: peixe-elefante

Caracteres distintivos: Focinho com probóscide localizada na frente da boca; nadadeira anal desenvolvida, inclinada para trás e pontiaguda, quase encostando na nadadeira caudal; nadadeira caudal com o lobo superior longo e terminando em ponta; macho com clasper não bifurcado.

Tamanho: machos podem ultrapassar $85 \mathrm{~cm}$ de comprimento total e as fêmeas ultrapassam um metro de comprimento.

Distribuição, Hábitos e Biologia: Essa espécie se distribui entre a costa do Estado do Rio de Janeiro até a costa do Estado do Rio Grande do Sul (Brasil), Uruguai, Argentina, Chile e Peru. Vivem em águas cujos substratos podem ser rochosos, arenosos e de lama. Alimentação básica de moluscos bivalvos e gastrópodes, e também poliquetas. Fazem migrações para águas mais rasas na primavera e outono, voltando para águas mais profundas no inverno. Espécie não rara no Rio de Janeiro, com indivíduos capturados em redes de espera e comercializados. Em geral habitam águas costeiras até 200 metros, embora existam registros em profundidades de 600 metros.

As fêmeas ficam sexualmente maduras com 46,6 cm de comprimento précaudal e os machos amadurecem a partir de 42,5 cm. Com 45,5 cm de comprimento pré-anal os machos são adultos.

Hydrolagus alberti Bigelow \& Schroeder, 1951 (Fig. 350)

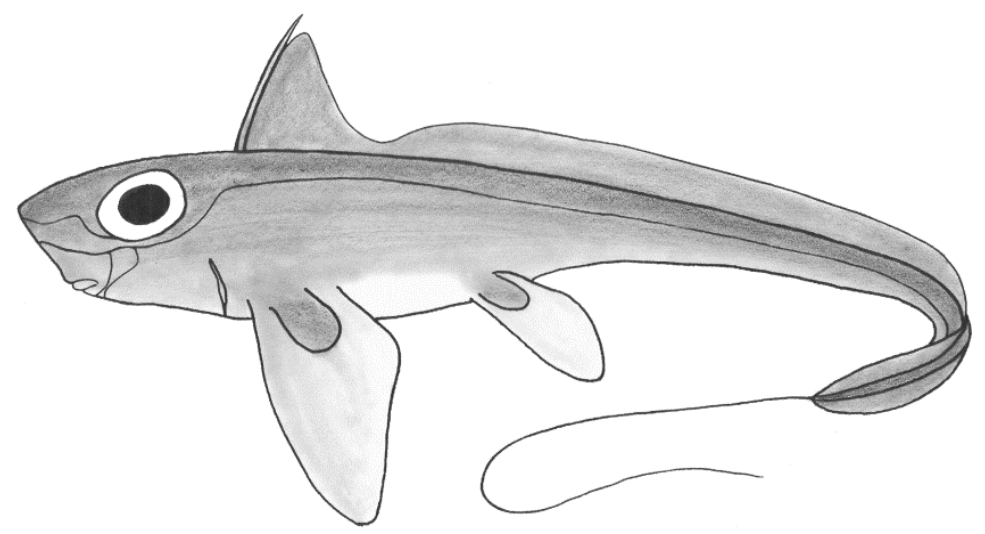


Nomes populares: quimera marrom

Caracteres distintivos: Corpo afilado da cabeça ao tronco, e uma cauda semelhante a um chicote, com um filamento terminal longo. Segunda nadadeira dorsal alongada com margem distal reta (não ondulada como em $H$. matallanasi). Coloração marrom escura uniforme dorsalmente e, ventralmente, incluindo bases das peitorais; nadadeira anal ausente. Clásperes bifurcados.

\section{Hydrolagus matallanasi Soto \& Vooren, 2004 (Fig. 351)}

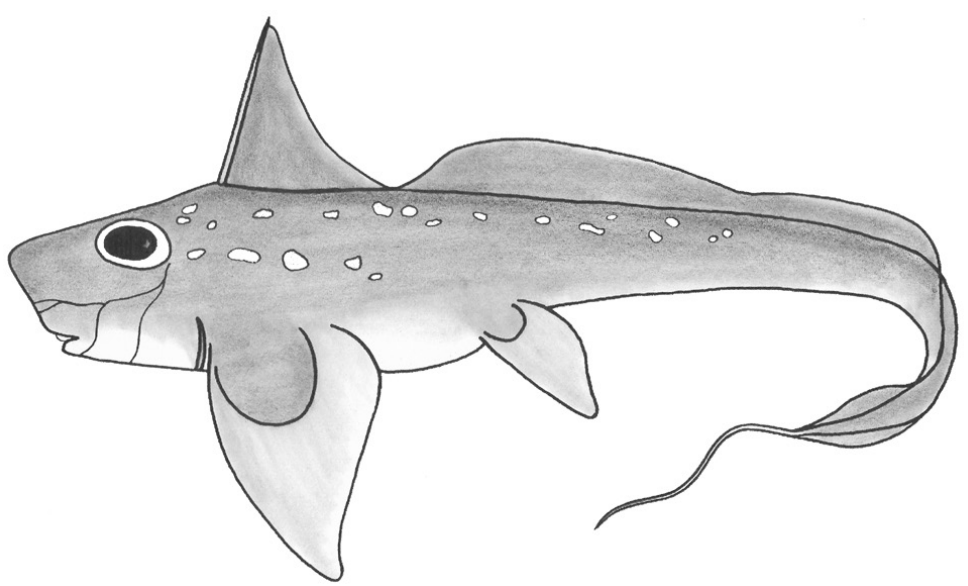

Nomes populares: quimera-malhada

Caracteres distintivos: Corpo afilando da região anterior para a posterior, terminando em uma cauda semelhante a um chicote, com filamento terminal longo; segunda nadadeira dorsal com margem distal ondulada (e não reta como em $H$. alberti). Coloração marrom irregular, com reticulações e manchas no corpo; superfície ventral esbranquiçada, incluindo as bases das peitorais; margem proximal da segunda nadadeira dorsal esbranquiçada; nadadeira peitoral longa, sua ponta estendendo-se para além da margem posterior da base da nadadeira pélvica; nadadeira anal ausente; clásperes bifurcados; dentes em forma de placas exibindo a coloração amarelada e cinza.

Tamanho: O tamanho obtido é baseado no comprimento pré caudal (da ponta do focinho até a abertura urogenital). Isso se justifica porque essa quimera é muito rara, havendo apenas 21 exemplares conhecidos até então. Como a cauda termina em um filamento que muitas vezes pode estar danificado, a medida pré-caudal acaba sendo a mais confiável. Os machos variam em tamanho de 234 a $302 \mathrm{~mm}$ de comprimento pré-caudal e as fêmeas, de 268 a $378 \mathrm{~mm}$.

Distribuição, Hábitos e Biologia: Observando os clasperes, os machos já são maduros em torno de 296 a $302 \mathrm{~mm}$ de comprimento pré caudal. Não se conhece com que tamanho as fêmeas se tornam maduras e nem o tamanho ao nascer.

Esta espécie tem sua distribuição registrada entre as costas dos Estados do Rio de Janeiro e de Santa Catarina, habitando águas profundas entre 416 a 736 metros de profundidade. 
Observações: $\mathrm{O}$ aparecimento dessa espécie no Rio de Janeiro deve ser devido à corrente do Brasil, que favorece o deslocamento de organismos antitropicais para essa região (Moreira Jr et al., 1993). O Rio de Janeiro é o registro mais ao norte da espécie.

Tamanho: alcançam até um metro de comprimento total.

Distribuição, Hábitos e Biologia: Pouco se conhece sobre a biologia dessa espécie. Provavelmente, como a maioria das quimeras, se alimenta de invertebrados bentônicos.

\section{AGRADECIMENTOS}

Os autores são gratos às seguintes pessoas que colaboraram de forma direta ou indireta na preparação deste trabalho:

Acácio R. G. Tomás, Carmen Wongtshowski, Carlo M. da Cunha, Carolus M. Vooren, Cláudio L. Sampaio, Daniel Figueroa, Diego Vaz, Dione Seripierri, Everaldo L. Queiroz (in memorian), Fábio Hazin, Fábio S. Motta, Gabriela Sonkajärvi, George Burgess, Geremy Cliff, Getúlio Rincón Filho, Gustavo Nunan (in memorian), Harold L. Pratt Jr., João Pedro Barreiros, John McEachran, John Stevens, José Lima de Figueiredo, José V. Andreata, Karla Soares, Laura Paesch, Leonard Compagno, Luis Lucifora, Manasi S. Rebouças, Manoel A. Furtado Neto (in memorian), Manoel Mateus Gonzales, Marcelo R. Carvalho, Marcelo Vianna, Márcia Aguieiras, Matthias Stehmman, Maurício Almeida, Nelson Dreux (in memorian), Patrícia Charvet-Almeida, Patrícia Oddone, Paulo M.M. Brito, Paulo Oliveira, Paulo Schwingel, Peter Last, Rafael C. Namora, Ricardo S. Rosa, Roberto C. Menni, Rosangela Lessa, Sarah Viana Lisher, Sebastião Medeiros (in memorian), Teodoro Vaske Júnior e Valéria Gallo.

\section{BIBLIOGRAFIA SUGERIDA}

AGUIAR, A. A.; GALLO, V. \& VALENTIN, J. L. 2004. Using the size independent discriminant analysis to distinguish the species of Myliobatis Cuvier (Batoidea: Myliobatidae) from Brazil. Zootaxa, 464: 1-7.

ALECRIM-SANTOS, C. A.; ANDREATTA, J. V. \& GOMES, U. L. 1988. Sobre a ocorrência de Rhincodon typus SMITH, 1829 (Elasmobranchii, Rhincodontidae) em águas brasileiras e aspectos de sua taxonomia. Acta Biologica Leopoldensia, v. 10, n. 2, p. $175-182$. 
ANDRADE, A. C.; SILVA-JÚNIOR, L. C. \& VIANNA, M. 2008. Reproductive biology and population variables of the Brazilian sharpnose shark Rhizoprionodon lalandii (Müller \& Henle, 1839) captured in coastal waters of south-eastern Brazil. Journal of Fish Biology, 72: 473-484.

BARBOSA, F. S. \& GOMES, U. L. 1998. Morfologia juvenil de quatro espécies do gênero Raja (Linnaeus, 1758) das regiões sudeste e sul do Brasil (Chondrichthyes, Rajidae). Biociências, Porto Alegre, v. 6, n. 2, p. 125-146.

BASS, A. J. D'AUBREY \& KISTNASAMY, N. 1976. Sharks os the east coast of southern Africa. VI. The families Oxynotidae, Squalidae, Dalatiidae and Echinorhinidae. $S$. African Assoc. for Mar. Biol. Res. Invest. Rep. 45., 1-103.

BATISTA, V. S. 1987. Desenvolvimento sexual de Zapteryx brevirostris (Müller \& Henle, 1841), no litoral do Rio de Janeiro, Brasil. Revista Brasileira de Biologia, v. 47, n. 3: 301-307.

BATISTA, V. S. 1987. Length-weight relationship of the little guitarfish, Zapteryx brevirostris (Chondrichthyes, Rhinobatidae), from Itaipu Inlet, Rio de Janeiro, Brazil. Copeia, v. 3: 787-789.

BATISTA, V. S. 1992. Aspectos quantitativos da fecundidade e do desenvolvimento embrionário da raia Zapteryx brevirostris (Müller \& Henle, 1841) (Pisces, Rhinobatidae) da Enseada de Itaipu, Niterói, Rio de Janeiro. Revista Brasileira de Biologia, v. 51, n. 3: 495-501.

BIGELOW, H. B. \& SCHROEDER, W. C. 1948. Sharks. In: Fishes of the Western North Atlantic. Sears Foundation for Marine Research, v. 1, n.1: 59-576.

BIGELOW, H. B. \& SCHOREDER, W. C. 1953. Sawfishes, guitarfishes, skates and rays, and chimaeroids. In: Fishes of the western North Atlantic, Part 2, Sears Foundation for Marine Reseach. 1, n. 2: 1-588.

BIGELOW, H. B. \& SCHROEDER, W. C. 1957. A study of the sharks of the suborder Squaloidea. Bulletin of the Museum of Comparative Zoology 117:1-150.

BONFIL, R. 1994. Overview of world elasmobranch fisheries. FAO Fisheries Technical Report, v. 341: 1-119.

BUCKUP, P. A.; NUNAN, G.; GOMES, U. L; COSTA, W. J. E. M. \& GADIG, O. B. F. 20oo. Peixes. In: Espécies Ameaçadas de Extinção no Município do Rio de Janeiro. Flora e Fauna. Secretaria da Cidade do Rio de Janeiro. Secretaria Municipal de Meio Ambiente. 68 pp. 
CARRIER, J. C.; MUSICK, J. A. \& HEITHAUS, M. R. (editors). 2004. Biology of sharks and their relatives. CRC Press. London. 596 pp.

CARVAlHO-FILHO, A. 1999. Peixes: costa brasileira. São Paulo, Editora Melro, 320 pp.

CARVALHO, M.R. ; LOBODA, T.S. \& SILVA, J.P.C.B. 2016. A new subfamily Styracurinae and new genus, Styracura, for Himantura schmardae (Werner, 1904) and Himantura pacifica (Beebe \& Tee Vanm 1941) (Chondrichthyes, Myliobatiformes). Zootaxa 4175 (3):201-221.

CARVALHO, M.R. 1999. A systematic revision of the electric ray genus Narcine Henle, 1834 (Chondrichthyes: Torpediniformes: Narcinidae), and the higher-level phylogenetic relationships of the orders of elasmobranch fishes (Chondrichthyes). Unpubl. PhD thesis, City University of New York. 726 p.

CARVAlHO, M. R. \& FIGUEIREDO, J. L. 1994. Psammobatis extenta (Garman, 1913): A senior synonym of Psammobatis glansdissimilis McEachran, 1983 (Chondrichthyes, Rajidae). Copeia, v. 1994: 1029-1033.

CARVALHO, M. R.; GOMES, U. L. \& GADIG, O. B. F. 2005. Description of a new species of skate of the genus Malacoraja Stehmann, 1970: the first species from the southwestern Atlantic Ocean, with notes on generic monophyly and composition (Chondrichthyes: Rajidae). Neotropical Ichthyology, 3(2):239-258.

CAVALCANTI, M.J.; GALLO-DA-SILVA, V. \& AFONSO, A. F. 1997. Identificação de Rhinoptera bonasus (Mitchill, 1815) e R. brasiliensis Müller \& Henle, 1841 (Chondrichthyes, Myliobatiformes, Rhinopteridae) pela análise de funções discriminantes. Acta Biologica Leopoldensia, v. 19, n. 2: 205-215.

CAVALCANTI, M. J.; GOMES, U. L. \& TOMÁS, A. R. G. 1996. Discriminação morfológica entre Rhizoprionodon porosus (Poey, 1861) e Rhizoprionodon lalandii (Valenciennes, 1839) (Elasmobranchii, Carcharhiniformes, Carcharhinidae): um estudo multivariado. Acta Biologica Leopoldensia, v. 18, n. 2: 103-118.

CHIERICHETTI, M.A.; SCENNA, L.B.; DI GIACOMO, E.E.; ONDANZA, P.M.; FIGUEROA, D.E. \& MIGLIORANCA, K. 2017. Reproductive biology of the cockfish Callorhinchus callorhynchus (Chondrichthyes, Callorhynchidae) in coastal Waters of the northern Argentinean Sea. Neotropical Ichthyology 15(2):1-7.

COMPAGNO, L. J. V. 1984a. FAO Species Catalogue. Sharks of the World. An Annotated and Illustrated Catalogue of Shark Species Known to Date. Part 1. Hexanchiformes to Lamniformes. FAO Fisheries Synopsis, v. 4, n. 125: 1-249. 
COMPAGNO, L. J. V. 1984b. FAO Species Catalogue. Sharks of the World. An annotated and illustrated catalogue of shark species known to date. Part 2. Carcharhiniformes. FAO Fisheries Synopsis, v. 4, n. 125: 251-655.

COMPAGNO, L. J. V. 2001. Sharks of the world. An annotated and illustrated catalogue of shark species known to date. Volume 2. Bullhead, mackerel and carpet sharks (Heterodontiformes, Lamniformes and Orectolobiformes). FAO Species Catalogue for Fishery Purposes, v. 1, n. 2: 269 pp.

COMPAGNO, L. J. V. 2002. Sharks. In: Carpenter, K. (Ed.) The living marine resources on the western North Atlantic. FAO Species Identification Guide for Fishery Purposes and American Society of Ichthyologists and Herpetologists, Special Publication, 5:358505.

COMPAGNO, L.J.V. 2003. Sharks (pp 357-505). In: Carpenter, K.E. The living marine resources of the Western Central Atlantic Vol.1, 599p.

COMPAGNO, L. J. V.; DANDO, M. \& FOWLER, S. 2005. Sharks of the World. Princeton University Press, Princeton. 368 pp.

DI DARIO, F.; PETRY, A.C.; MINCARONE, M.M.; PEREIRA, M.M.S.; SANTOS, R.M, 2011. New records of coastal fishes in the northern Rio de Janeiro State, Brazil with comments on the geography of the south-western Atlantic Ocean, Journal of Fish Biology 79(2):546-555.

DIDIER, D.A. 1995. Phylogenetic systematics of extant chimaeroid fishes (Holocephali, Chimaeroidei). American Museum Novitates (3119): 1-86.

DIDIER, D.A. 2004. Phylogeny and classification of extant Holocephali. In. J.C. Carrier; J.A. Musick and M.R. Heithaus (Eds). Biology of Sharks and Their Relatives. Chapter 4: 115-135, CRC Press, 595 p.

FARIA, V. V. 1998. Estrutura da comunidade de Elasmobrânquios em um Recife Artificial no litoral Norte do estado do Rio de Janeiro. Rio de Janeiro. Monografia de Conclusão do Curso de Ciências Biológicas, Universidade Estadual do Norte Fluminense. 96 pp.

FARIA, V. V. 2001. Biologia reprodutiva de Mustelus higmani Springer E Lowe, 1963 (Elasmobranchii, Triakidae) na Enseada de Manguinhos, litoral norte do Estado do Rio de Janeiro. Dissertação de Mestrado, Universidade Estadual Norte Fluminense. 66 p.

FERREIRA, B. P. 1988. Ciclo reprodutivo de Rhizoprionodon lalandii (Valenciennes) e $R$. porosus (Poey) (Selachii, Carcharhinidae) na região de Barra de Guaratiba, RJ. Anais da Academia Brasileira de Ciências, v. 6o, n. 1: 91- 101. 
FIGUEIREDO, J. L. 1977. Manual de Peixes Marinhos do Sudeste do Brasil. I. Introdução. Cações, Raias e Quimeras. Museu de Zoologia, Universidade de São Paulo. 104 pp.

FOWLER, S. L.; REED, T. M. \& DIPPER, F. A. (Eds.) 2002. Elasmobranch biodiversity, conservation and management. Proccedings of the International Seminar and Workshop, Sabah, Malaysia, July 1997. IUCN SSC Shark Specialist Group. IUCN, Gland, Switzerland and Cambridge. 258 pp.

FOWLER, S. L.; CAVANAGH, R. D.; CAMHI, M.; BURGESS, G. H.; CAILLIET, G. M.; FORDHAM, S. V.; SIMPFENDORFER, C. A. \& MUSICK, J. A. (Eds.) 2005. Sharks, rays and chimaeras: the status of the chondrichthyan fishes. Status Survey. IUCN SSC Shark a Group. IUCN, Gland, Switzerland and Cambridge. 461 pp.

GADIG, O. B. F. 2001. Tubarões da Costa Brasileira. Tese de Doutorado, Instituto de Biociências, Unesp, Rio Claro. 343 pp.

GADIG, O. B. F \& SAMPAIO, C.L., 2002. Ocorrência de Mobula japanica no Atlântico Ocidental e Mobula tarapacana em águas brasileiras com comentários sobre a diversidade de raias manta (Chondrichthyes, Mobulidae) no Brasil. Arq, Ciên. Mar. Fortaleza, 35: 36-37.

GADIG, O. B. F. \& ROSA, R. S. 1996. Occurrence and distribution of the white shark, Carcharodon carcharias, in Brazilian waters. In: KLIMLEY, P. A., AINLEY, D. G. (eds.) Biology of White Shark. San Diego, Academic Press: 347-350.

GARRICK, J. A. F. 196o. Studies on New Zealand Elasmobranchii. Part XII, The species of Squalus from New Zealand and Australia; and a general account and key to the New Zealand Squaloidea. Transactions of Royal Society of New Zealand. Vol.88, part 3: 519-557.

GARRICK, J. A. F. 1982. Sharks of the genus Carcharhinus. NOAA Technical Report, NMFS, v. 445: 1-194.

GILBERT, C. R. 1967. A revision of the hammerhead sharks (Family Sphyrnidae). Proceedings of the U. S. National Museum, v. 119, n. 3539: 1-88.

GOMES, U.L. 2002. Revisão taxonômica da família Rajidae no Brasil (Chondrichthyes, Elasmobranchii, Rajiformes). Tese. Universidade Federal do Rio de Janeiro - Museu Nacional, 288 p. 231 figs.

GOMES, U. L. \& PARAGÓ, C. L. D. 2001. Espécie nova de Rajídeo (Chondrichthyes, Rajiformes) do Atlântico sul ocidental. Boletim do Museu Nacional, Rio de Janeiro, v. 448: 1-10. 
GOMES, U. L. \& PARAGÓ, C. L. D. 2005. A utilização da distribuição dos poros de canais de muco e da coloração ventral como caracteres taxonômicos em Riorajini (Chondrichthyes, Batoidea, Rajidae). Biociências, Porto Alegre, v. 13, n. 1: 55-62.

GOMES, U. L. \& PICADO, S. S. 2001. Distribution of the species of Dipturus Rafinesque (Rajidae, Rajinae, Rajini) off Brazil and first record of the Caribbean skate D. teevani (Bigelow \& Schroeder) in the Western South Atlantic. Revista Brasileira de Zoologia, Curitiba, v. 18, n. 1: 171-185.

GOMES, U. L. \& TOMÁS, A. R. G. 1991. Dimorfismo sexual secundário no cação Scyliorhinus haeckelli Ribeiro, 1907 (Elasmobranchii, Scyliorhinidae). Anais da Academia Brasileira de Ciências, v. 63, n. 2:193-200.

GOMES, U. L.; LIMA, M. C.; PARAGÓ, C. L D. \& QUINTANS, A. P. 1997. Catálogo das coleções ictiológicas do Departamento de Biologia Animal e Vegetal. Instituto de Biologia. Universidade do Estado do Rio de Janeiro. 185 pp.

GOMES, U. L.; SIGNORI, C. N. \& GADIG, O. B. F. 2006. Report on the smallfin catshark Apristurus parvipinnis Springer \& Heemstra (Chondrichthyes, Scyliorhinidae) in Western South Atlantic with notes on its taxonomy. Pan American Journal of Aquatic Sciences, v. 1, n. 2: 99-103.

GRACE, M. A., M. H. DOOSEY, J. S. S. DENTON, G. J. P. NAYLOR, H. L. BART JR. AND J. G. MAISEY 2019. A new Western North Atlantic Ocean kitefin shark (Squaliformes: Dalatiidae) from the Gulf of Mexico. Zootaxa 4619 (no. 1): 109-120.

HAMLETT, W. C. 1999. (editor). Sharks, Skates, and Rays: the Biology of Elasmobranch Fishes. Johns Hopkins University Press, Baltimore. 515 pp.

HAMLETT, W. C. 2005. (editor) Reproductive biology and phylogeny ofChondrichthyes. Science Publishers. Plymouth. 562 pp.

HEEMSTRA, P. C. 1997. A review of the smooth-hound sharks (genus Mustelus, family Triakidae) of the western Atlantic ocean, with descriptions of two new species and a new subspecies. Bulletin of Marine Sciences, v. 6o, n. 3: 894-928.

HENNEMANN, R. M. 2001. Sharks E Rays. Elasmobranch Guide of the World. IKAN, Frankfurt. $304 \mathrm{pp}$.

HONEBRINK, R.; BUCH, R.; GALPIN, P. \& BURGESS, H. 2011. First documented attack on live human by a cookiecutter attack (Squaliformes, Dalatiidae, Isistius sp.). Pacific Science, vol. 65 (3): 365-374. 
HUMAN, A. B., OWEN, E. P., COMPAGNO, L. J. V. \& HARLEY, E. H. 20o6. Testing morphologically based phylogenetic theories within the cartilaginous fishes with molecular data, with special reference to the catshark family (Chondrichthyes, Scyliorhinidae) and the interrelationships within them. Molecular Phylogenetics and Evolution 39: 384-391.

JONES, E. 1971. Isistius brasiliensis, a squaloid shark, the probable cause of crater wounds in fishes and cetaceans. Fish. Bull., v. 69, n. 4, p. 791-798.

JOUNG, S. J.; CHEN, C. T.; CLARK, E.; UCHIDA, S. \& HUANG, Y. P. 1996. The whale shark, Rhincodon typus, is a livebearer: 300 embryos found in one "megamamma" supreme. Environmental Biology of Fishes, v. 46: 219-223.

LAST, P. R. \& STEVENS, J. D. 1994. Sharks and Rays of Australia. Australia, CSIRO Division of Fisheries. 513 pp.

LAST, P. R., SÉRET, G. J. P. NAYLOR \& MANJAJI-MATSUMOTO B. M. 2016 a. A revised classification of the family Dasyatidae (Chondrichthyes: Myliobatiformes) based on new morphological and molecular insights. Zootaxa 4139 (3):345-368.

LAST, P. R., SÉRET, B. \& NAYLOR, G. J. P. 2016 b. A new species of guitarfish, Rhinobatos borneensis sp. nov. with a redefinition of the family-level classification in the order Rhinopristiformes (Chondrichthyes: Batoidea). Zootaxa 4117 (4): 451-475.

LAST, P. R. , WHITE, W.T., M. R. CARVALHO, B. SÉRET, M. F. W.\& NAYLOR, G.J.P. 2016 c Rays of the world. CSIRO Publishing.790 p.

LEBRUN,P. 2001. Requins, Raies et autres chondrichthyes fossils. Tome I. diversité, anatomie, classification et phylogenèse et autres chondrichthyes. Mineraux E Fossiles. Hors-série 12, 113p.

LESSA, R. P. T. 1988. Premières observations sur la biologie reproductive de Rhizoprionodon lalandei (Valenciennes, 1839) (Pisces, Carcharhinidae) de la côte nord du Brésil - Maranhão. Revista Brasileira de Biologia, v. 48, n. 4: 721-730.

LESSA, R. P. T. 1997. Sinopse dos estudos sobre elasmobrânquios da costa do Maranhão. Boletim do Laboratório de Hidrobiologia, São Luís, v.10: 19-36.

LESSA, R. P. T.; PAGLERANI, R. \& SANTANA, F. M. 1999. Biology and morphometry of the oceanic whitetip shark, Carcharhinus longimanus (Carcharhinidae), off NorthEastern Brazil. Cybium, v. 23, n. 4: 353-368. 
LESSA, R. P.; SANTANA, F. M.; RINCÓN, G.; GADIG, O. B. F.; EL-DEIR, A. C. 1999. Biodiversidade de elasmobrânquios do Brasil. Recife, PRONABIO, $125 \mathrm{pp}$.

LEVY, J. A. \& CONCEIÇÃO, M. B. 1989. Biochemical evidences for two sibling species of genus Myliobatis (Chondrichthyes: Myliobatidae) in South Brazil. Comparative Biochemistry Physiology, v. 94B, n. 4: 687-69o.

LIMA, L. M.; RENNÓ, B. \& SICILIANO, S. 2009. Gigante dos mares em areias fluminenses. Ciência Hoje, vol.44, no 263: 56-57.

MAGLIOCCA, A. 1987. Glossário de Oceanografia. Editora da Universidade de São Paulo. 355 pp.

MARQUES, A. R. 1999. O gênero Squalus no Brasil: caracterização do grupo megalops e determinação do status taxonômico das formas brasileiras. Rio de Janeiro. Dissertação de Mestrado em Zoologia, Museu Nacional, Universidade Federal do Rio de Janeiro. $117 \mathrm{pp}$.

MARSHALL, A. D., COMPAGNO, L. J.V. \& BENNETT, MICHAEL B. 2009. Redescription of genus Manta with resurrection of Manta alfredi (Krefft, 1968) (Chondrichthyes; Myliobatoidei; Mobulidae). Zootaxa 2301: 1-28.

MATSUURA, Y. 1986. Contribuição ao estudo da estrutura oceanográfica da região sudeste entre Cabo Frio (RJ) e Cabo de Santa Marta Grande (SC). Ciência e Cultura, São Paulo, v. 38, n. 8:1439-1450.

MAZZOLENI, R. C. \& SCHWINGEL, P. R. 1999. Elasmobranch species landed in Itajaí Harbor, Southern Brazil. Notas Técnicas Facimar, v. 3: 111-118.

McEACHRAN, J. D. 1983. Results of the research cruises of FRV "Walther Herwig" to South America. LXI. Revision of the South American skate genus Psammobatis Günther, 1870. (Elasmobranchii: Rajiformes, Rajidae). Archives Fischereiwissenschaft Bundesforschungsanstalt für Fischerie, v. 34:23-80.

McEACHRAN, J. D. \& COMPAGNO, L. J. V. 1980. Results of the research cruises of FRV "Walter Herwig" to South America. LVI: A new species of skate from the Southwestern Atlantic, Gurgesiella dorsalifera sp. nov. (Chondrichthyes, Rajoidei). Archives Fischereiwissenschaft Bundesforschungsanstalt für Fischerie, v. 31:1-14.

McEACHRAN, J. D. \& DUNN, K. A. 1998. Phylogenetic analysis of skates, a morphologically conservative clade of Elasmobranchs (Chondrichthyes, Rajidae). Copeia, v. 2: 271-290. 
McEACHRAN, J. D. \& CARVALHO, M. R. 2002. Batoids. In: Carpenter, K. (Ed.) The living marine resources of the western North Atlantic. FAO Species Identification Guide for Fishery Purposes and American Society of Ichthyologists and Herpetologists, Special Publication, 5: 508-589.

MENEZES, N. A.; BUCKUP, P. A.; FIGUEIREDO, J. L. \& MOURA, R. L. (Eds). 2003. Catálogo das Espécies de Peixes Marinhos do Brasil. Museu de Zoologia, Universidade de São Paulo. 197 pp.

MENNI, R. \& STEHMANN, M. 200o. Distribution, environment and biology of batoid fishes off Argentina, Uruguay and Brazil. A review. Revista do Museu Argentino de Ciencias Naturales, v. 2, n. 1: 69-109.

MINCARONE, M. M.; MARTINS,A. S.; COSTA, P. A. S.; BRAGA, A. C. \& HAIMOVIC, M. 2017. Peixes marinhos da bacia de Campos: uma revisão da Diversidade. Comunidades Demersais Bioconstrutores.Cap. 8: 189-216.

MIRANDA RIBEIRO, A. M. 1907. Fauna Braziliense. Peixes (Desmobrânchios). Archivos Museu Nacional, v. 14: 137-171.

MIRANDA RIBEIRO, A. M. 1923. Fauna Braziliense. Peixes (Vol. II, $1^{\underline{a}}$ Parte). Fasc. 1. Rio de Janeiro, Imprensa Nacional: 1-52.

MOREIRA-JÚNIOR, W.; GOMES, U. L. \& MARQUES, A. R. 1993. Registro do "tubarão-de-sete-guelras" Heptranchias perlo (Bonaterre, 1788) e do "peixe-elefante" Callorhynchus callorhynchus (Linnaeus, 1758) (Pisces, Chondrichthyes) no litoral do Rio de Janeiro, Brasil. Acta Biologica Leopoldensia, v.15, n. 1:145-150.

MOTTA, F. S.; GADIG, O. B. F.; NAMORA, R. C. \& BRAGA, F. M. S. 2005. Size and sex compositions, length-weight relationship, and occurrence of the Brazilian sharpnose shark, Rhizoprionodon lalandii, caught by artisanal fishery from southeastern Brazil. Fisheries Research, v. 74: 116-126.

NAKAYA, K. \& SATO, K. 1999. Species grouping within the genus Apristurus (Elasmobranchii: Scyliorhinidae). Proceedings of the Fifth Indo-Pacific Fish Conference, Nouméa. Paris, Société Française d'Ichtyologie: 307-320.

NAYLOR, G. J. P., CAIRA, J. N., JENSEN, K., ROSANA, K. A. M., STRAUBE, N. \& LAKNER, C. 2012. Elasmobranch phylogeny: a mitochondrial estimate based on 595 species, p. 31-56. In: The Biology of sharks and their relatives. J.C. Carrier, J.A. Musick and M.R. Heith (eds). CRC Press, Boca Ratón, Florida. 
NOTARBARTOLO-DI-SCIARA, G. 1987. A revisionary study of the genus Mobula Rafinesque, 1810 (Chondrichthyes: Mobulidae) with the description of a new species. Zoological Journal of the Linnean Society, v. 97: 1-91.

NUNAN, G. W. 1992. Composition, species distribution and zoographical affinities of the Brazilian reef-fish fauna. PhD Thesis, University of Newcastle, United Kingdon, $584 \mathrm{p}$.

ODDONE, M. C. \& VOOREN, C. M. 2005. Reproductive biology of Atlantoraja cyclophora (Regan, 1903) (Elasmobranchii: Rajidae) off southern Brazil. ICES Journal of Marine Sciences, v. 62: 1095-1103.

ODDONE, M. C.; AMORIM, A. F.; MANCINI, P. L.; NORBIS, W. \& VELASCO, G. 2007. The reproductive biology and cycle of Rioraja agassizi (Müller and Henle, 1841) (Chondrichthyes: Rajidae) in southeastern Brazil, SW Atlantic Ocean. Scientia Marina, v. 71, n. 3: 593-604.

PARAGÓ, C. L. D. P. 2001. Contribuição à taxonomia do gênero Psammobatis (Günther, 1870) (Chondrichthyes, Rajidae). Caracterização das espécies do Subgrupo 1 de McEachran (1983), com base em padrões de coloração e espinulação. Dissertação de Mestrado, Museu Nacional, Universidade Federal do Rio de Janeiro. 52 pp.

PETEAN, F. F. 2014. Taxonomic review and comparative morphology of the species of the genus Isistius Gill,1864 (Chondrichthyes: Squaliformes: Dalatiidae). Dissertação, Instituto de Biociências, Universidade de São Paulo, xx + 258 p.

QUEIRÓZ, E. L. 1986. Estudo comparativo de alimentação de Sympterygia acuta Garman, 1877 e S. bonapartei Müller \& Henle, 1841 (Pisces, Rajiformes) com relação a: distribuição, abundância, morfologia e reprodução, nas águas litorâneas do Rio Grande do Sul. Dissertação de Mestrado, Fundação Universidade do Rio Grande. 326 pp.

RANDALL, J. E. Review of the biology of the tiger shark (Galeocerdo cuvier). Australian Journal of Marine and Freshwater Research, v. 43: 21- 31.

RIBEIRO, L.; RODRIGUES, G. \& NUNAN, G. 2006. First record of a pregnant female of Dasyatis hypostigma, with description of the embryos. Environmental Biology of Fishes, v. 75: 219-221.

RIBEIRO, P. M. 1961. Catálogo dos Peixes do Museu Nacional. VII. Elasmobrânquios. Publicações Avulsas do Museu Nacional, v.15:1-8. 
RIBEIRO, P. M. 1968. Apontamentos Ictiológicos. V. Heptranchias perlo. Boletim do Museu Nacional, Zoologia, v. 264: 1-5.

ROSA, R. S. \& MENEZES, N. A. 1996. Relação preliminar das espécies de peixes (Pisces, Elasmobranchii, Actinopterygii), ameaçadas no Brasil. Revista Brasileira de Zoologia, v. 13, n. 3: 647-667.

ROSAS, F. C. W.; CAPISTRANO, L. C.; DI BENEDITO, A. P. \& RAMOS, R. Hydrurga leptonyx recovered from the stomach of a tiger shark captured off the Rio de Janeiro coast, Brazil. Mammalia, v. 56, n. 1: 153-154.

ROUX, C. 1979. Campagne de la calypso au large des côtes Atlantiques de l'Amérique du Sud (1960-1961). Poissons Chondrichthyens du Plateau Continental Brésilien et du Rio de La Plata. Annales de l'Institut Oceanographique, v. 55: 11-30.

SADOWSKY, V. 1965. The hammerhead sharks of the littoral zone of São Paulo, Brazil, with the description of a new species. Bulletin of Marine Sciences, v.15, n. 1:1-12.

SADOWSKY, V.; AMORIM, A. F. \& ARFELLI, C. A. 1985. Record of unusual number of dwarf shark, Squaliolus laticaudus, off the South Coast of Brazil. Boletim do Instituto de Pesca, v. 12, n. 4: 45-50.

SANTOS. H. R. S. 2007. Revisão taxonômica das espécies viventes de dasyatidae (chondrichthyes, myliobatiformes) do atlântico ocidental. Tese (doutorado em Ciências Biológicas - Zoologia) - Universidade Federal do Rio de Janeiro, Museu Nacional, Programa de Pós-graduação em Zoologia, 2007. xi, 299.

SANTOS, H. R. S. \& CARVALHO, M. R. 2004. Description of a new species of whiptail stingray from the southwestern Atlantic ocean (Chondrichthyes, Myliobatiformes, Dasyatidae). Boletim do Museu Nacional, v. 516. 24 pp.

SIQUEIRA, A. E. \& SANT'ANNA, V. B. 2007. Data on the pelagic stingray, Pteroplatytrygon violacea (Bonaparte, 1832) (Myliobatiformes, Dasyatidae) caught in the Rio de Janeiro coast. Brazilian Journal of Oceanography, v. 55, n. 4:323-325.

SOARES, K. D. A, GADIG, O. B. F. \& GOMES, U. L. 2015 Scyliorhinus ugoi, a new species of catshark from Brazil (Chondrichthyes: Carcharhiniformes: Scyliorhinidae). Zootaxa, 3937 (2): 347-361.

SOARES, K. D. A., GOMES, U. L. \& CARVALHO, M. R. 2016. Taxonomic review of catsharks of the Scyliorhinus haeckelii group, with the description of a new species (Chondrichthyes: Carcharhiniformes: Scyliorhinidae) Zootaxa, 4066 (25): 501-534. 
SOARES, K. D.; CARVALHO, M. R., SCHWINGEL, P. R. \& GADIG, O. B. F. 2019. A new species of Parmaturus (Chondrichthyes: Carcharhiniformes: Scyliorhinidae) from Brazil, Southwestern Atlantic Copeia 107 (2):314-322.

SOTO, J. M. R. \& COSTA, P. A. S. 2010. New data on Rajella sadowskii (Chondrichthyes: Rajidae) from the deep south-western Atlantic. Marine Records: 1-8.

SPRINGER, S. 1966. A review of Western Atlantic cat sharks, Scyliorhinidae, with descriptions of a new genus and five new species. Fishery Bulletin, v. 65, n. 3: 581-624.

SPRINGER, S. 1979. A revision of the catsharks, Family Scyliorhinidae. NOAA Technical Report, NMFS, v. 422: 1-97.

SPRINGER, V. G. \& GOLD, J. P. 1989. Sharks in Question. Smithsonian Institution Press, Washington. $187 \mathrm{pp}$.

STEHMANN, M. F. W. 2002. Proposal of a maturity stages scale for oviparous and viviparous cartilaginous fish (Pisces, Chondrichthyes). Archive of Fishery and Marine Research, 50; 23-48.

STEVENS, J. D., BONFIL, R., DULVY, N. K. \& WALKER, P. A. 2000. The effects of fishing on sharks, rays, and chimaeras (chondrichthyans), and the implications for marine ecosystems. ICES Journal of Marine Science, v. 57: 476-494.

STONE, N. R. \& SHIMADA, K. 2019. Skeletal anatomy of big-eyed sand tiger shark wordpis noronhai (Lamniformes: Osontaspididae), and its implication for lamniform phylogeny, taxonomy and conservation biology. Copeia 107(4): 632-652.

TOMÁS, A. R. G. 1985. Interrelações de fatores ambientais com a ocorrência de elasmobrânquios (Pisces, Chondrichthyes) na pesca de Barra de Guaratiba, Rio de Janeiro. Monografia de Bacharelado em Oceanografia, Universidade do Estado do Rio de Janeiro. $40 \mathrm{pp}$.

TOMÁS, A. R. G. \& GOMES, U. L. 1989. Observações sobre a presença de Cetorhinus maximus (Gunnerus, 1765) (Elasmobranchii, Cetorhinidae) no sudeste e no sul do Brasil. Boletim do Instituto de Pesca, v. 16, n. 1: 111-116.

TOMÁS, A. R. G. \& TUTUI, S. L. S. 1996. Identificação de carcaças de cações e raias da pesca comercial no sudeste do Brasil. Anais da Academia Brasileira de Ciências, v. 68, n. $4: 583-591$. 
TUBINO, R. A.; MONTEIRO-NETO, C.; MORAES, L. E. S. \& PAES, E. T. 2007. Artisanal fisheries production in the coastal zone of Itaipu, Niterói, RJ, Brazil. Brazilian Journal of Oceanography, 55(3):187-197.

VALENTIN, J. L.; ANDRÉ, D. L. \& JACOB, S. A. 1987. Hydrobiology in the Cabo Frio (Brazil) upwelling: two dimensional structure and variability during a wind circle. Continental Shelf Research, v. 7: 77-88.

VASKE JÚNIOR, T. \& RINCÓN FILHO, G. 1998. Conteúdo estomacal dos tubarões azul (Prionace glauca) e anequim (Isurus oxyrinchus) em águas oceânicas no Sul do Brasil. Revista Brasileira de Biologia, v. 58, n. 3: 445-452.

VAZ, D. B. 2015. Revisão taxonômica e morfológica do gênero Centroscymnus Barboza du Bocage \& Britto-Capello, 1864, com comentários no arranjo genérico da família Somniosidae (Chondrichthyes: Squaliformes). Dissertação, Instituto de Biociências, Universidade de Sâo Paulo. xxi+570 p.

VAZ, D. B. \& CARVALHO, M R. , 2013. Morphological and taxonomic revision of species of Squatina from the Southwestern Atlantic Ocean (Chondrichthyes: Squatiniformes: Squatinidae). Zootaxa (3695): $81 \mathrm{pp}$.

VAZ, D. B. \& CARVALHO M. R., 2018. New Species of Squatina (Squatiniformes: Squatinidae) from Brazil, with comments on the taxonomy of Angel Sharks from the Central and Northwestern Atlantic. Copeia 106, (1): 144-16o.

VIANA, S. T. F., CARVALHO. M. R. \& GOMES, U. L. 2016. Taxonomy and morphology of species of the genus Squalus Linnaeus, 1758 from the Southwestern Atlantic Ocean (Chondrichthyes: Squaliformes: Squalidae). Zootaxa 4133 (1): 1-89.

VOOREN, C. M. \& da SILVA, K. G. 1991. On the taxonomy of the angel sharks from southern Brazil, with the description of Squatina occulta sp. n. Revista Brasileira de Biologia, v. 51, n. 3: 589-602.

VOOREN, C. M. \& KLIPPEL, S. (Eds.) 2005. Ações para a Conservação de tubarões e raias no sul do Brasil. Igarapé, Porto Alegre: 261 pp.

WEIGMANN, S., STEHMANN, M. F. W. \& THIES, R., 2014, Rajella paucispinosa n.sp. a new deep-water skate (Elasmobranchii, Rajidae) from the western Indian Ocean off South Mozambique, and a revised generic diagnosis. Zootaxa 3847 (3): 359-387.

WEIGMANN, S. 2016. Annotated checklist of the living sharks, batoids and chimaeras (Chondrichthyes) of the world, with a focus on biogeographical diversity. Journ. Fish, Biol. 88: 837-1037. 
WHITE, W. T., 2014. A revised generic arrangement for the eagle ray family Myliobatidae, with definitions for the valid genera. Zootaxa 386o(2):149-166.

White, W. T., CORRIGAN, S., YANG, L., HENDERSON, A. C., BAZINET, A. L., SWOFFORD D. L. \& NAYLOR, G. J. P., 2018. Phylogeny of the manta and devil rays (Chondrichthyes: Mobulidae), with an updated taxonomic arrangement for the family. Zoological Journal of the Linnean Society, 182, 50-75. With 8 figures.

WHITE, W. T. \& NAYLOR, G. J. P, 2016. Resurrection of the family Aetobatidae (Myliobatiformes) for the pelagic eagle rays, genus Aetobatus. Zootaxa 4139(3): 435438.

WOURMS, J. P. 1977. Reproduction and development in Chondrichthyan fishes. American Zoologist, v. 17, n. 2:379-41.

YOKOTA, L.; WHITE, W. T. \& CARVALHO, M. R. 2016. Butterfly rays, Family Gymnuridae.Chapter 24, pp 510-521. In: Rays of the World (Last, P.R.;White, W.T.; Carvalho, M.R.; Serét, B.; Stehmann, M.F.W. \& Naylor, G.J.P. (eds). CSIRO Publishing, Cornell University Press, 790 p.

YOKOTA, L. \& CARVALHO, M. R. 2017. Taxonomic and morphological revision of butterfly rays of the Gymnura micrura (Bloch \& Schneider, 1861) species complex with the description of two new species (Myliobatiformes, Gymnuridae). Zootaxa 4332 (1) $1-74$. 


\section{Prancha I}
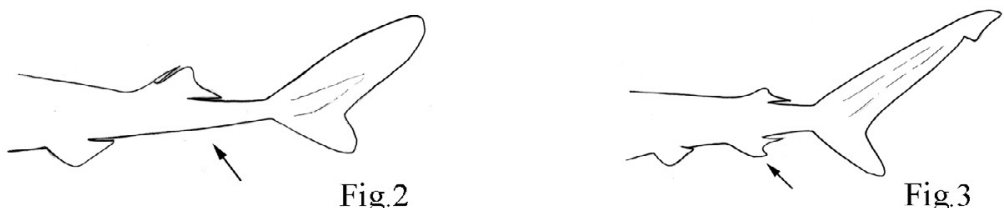

Fig. 3

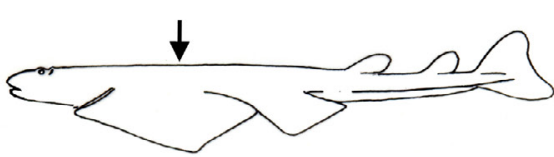

Fig. 4

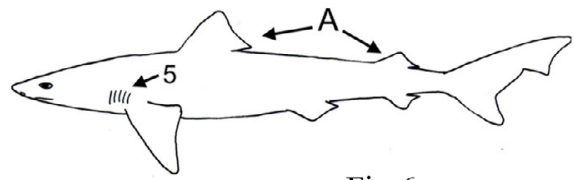

Fig.6

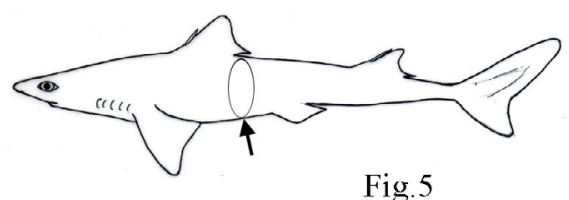

Fig. 5

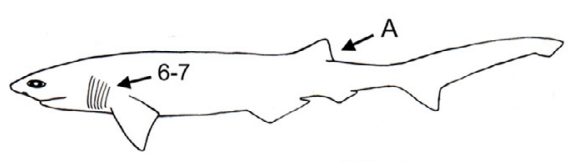

Fig. 7
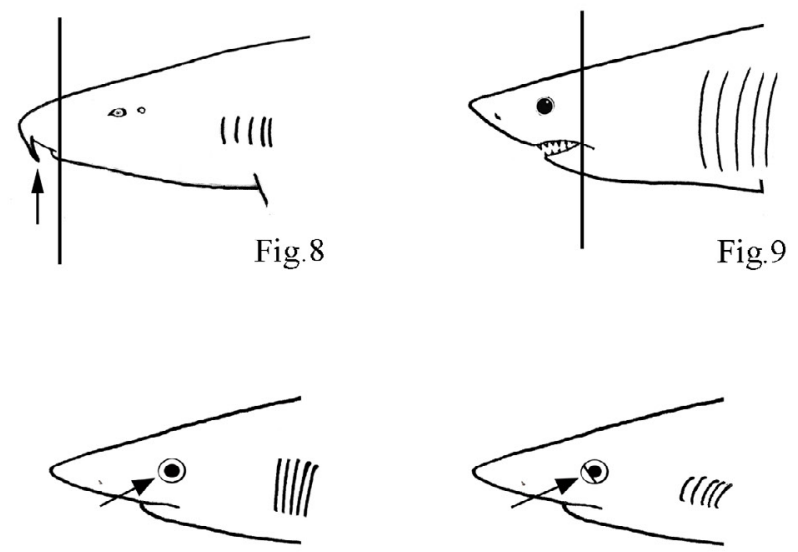

Fig. 10

Fig. 11

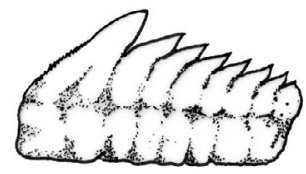

Fig. 12 


\section{Prancha II}

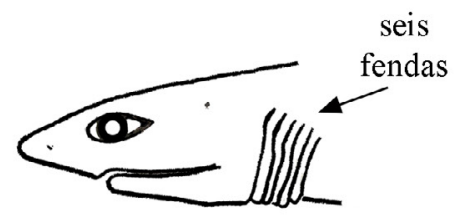

Fig. 13

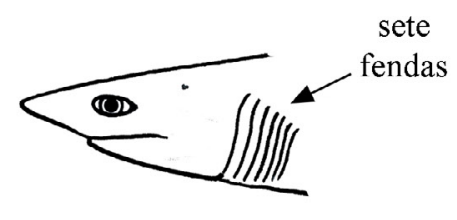

Fig. 14
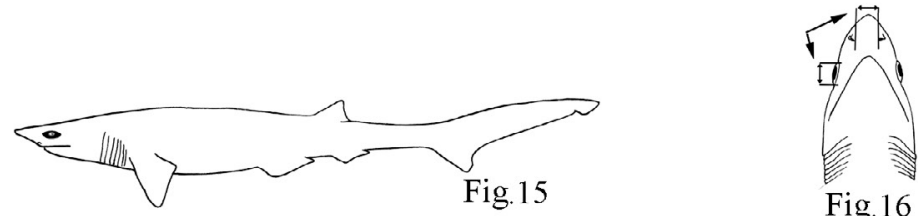

Fig. 16
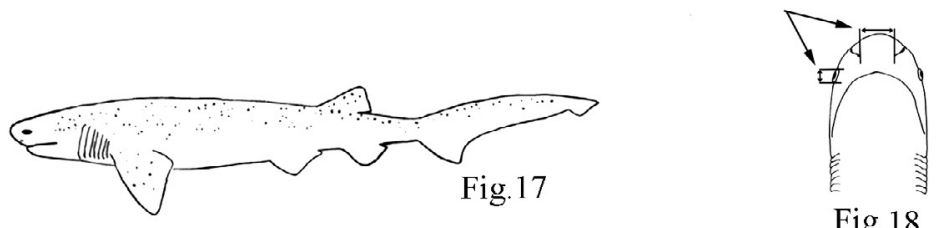

Fig. 18

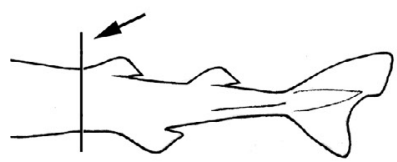

Fig. 23

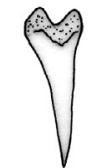

Fig. 25

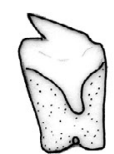

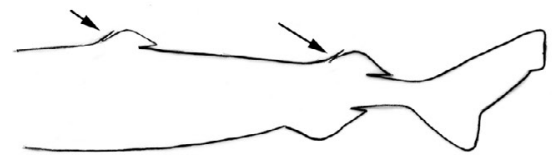

Fig. 26

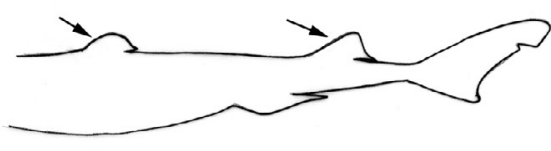

Fig. 27 
Prancha III
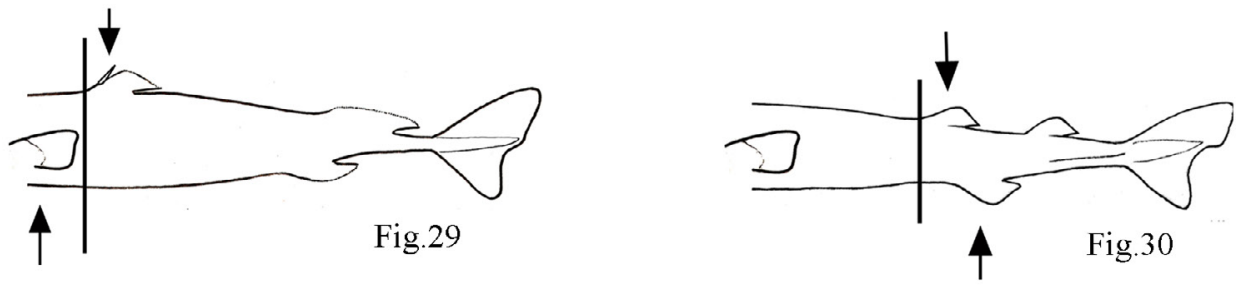

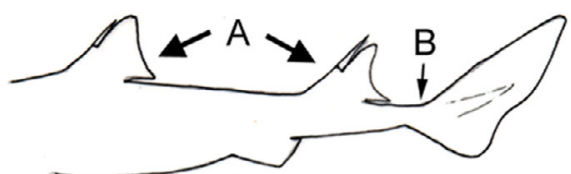

Fig. 33
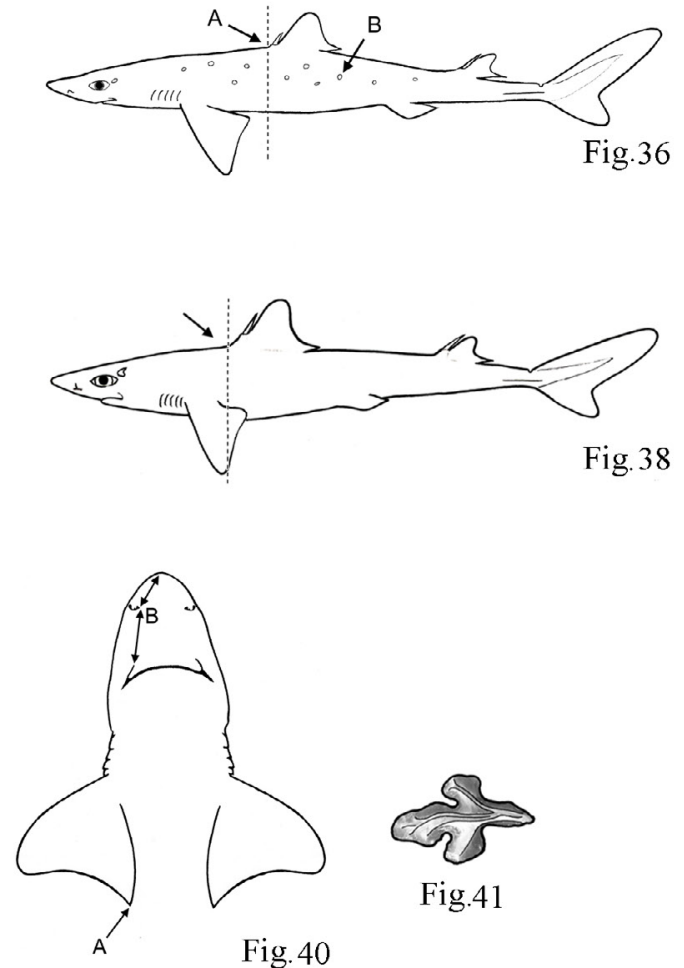

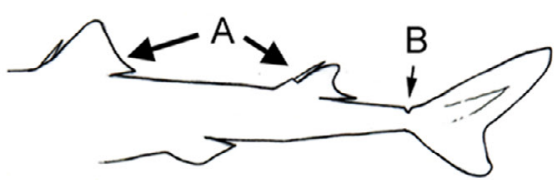

Fig.34
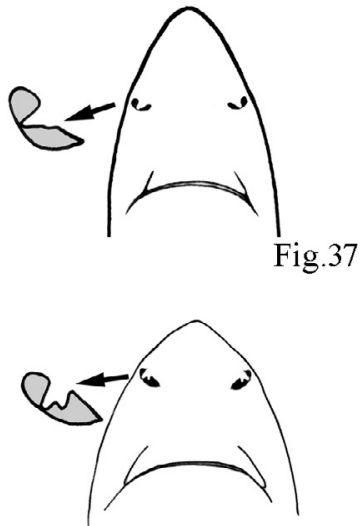

Fig. 39

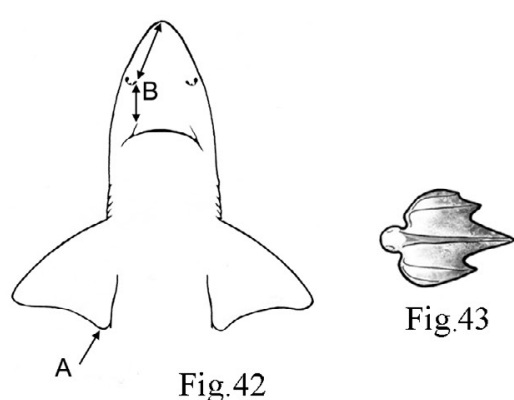




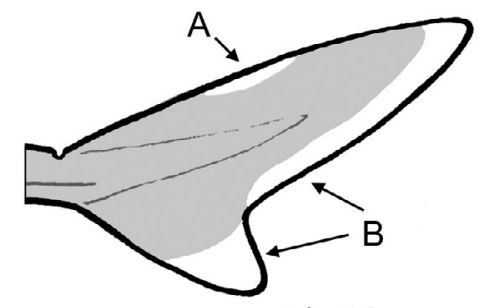

Fig. 46
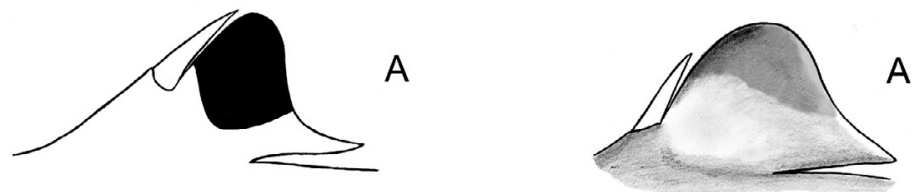

Fig.47

Fig. 48
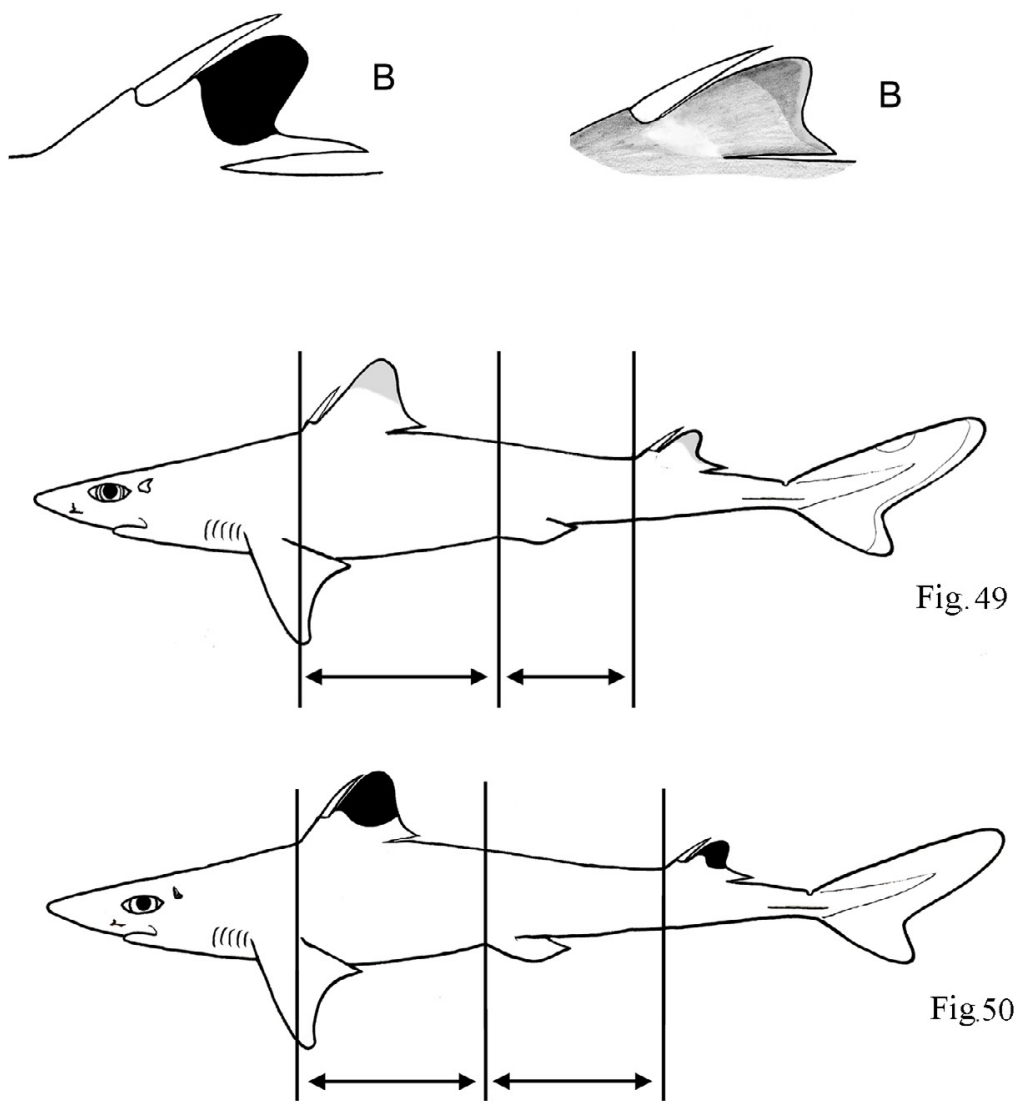


\section{Prancha V}

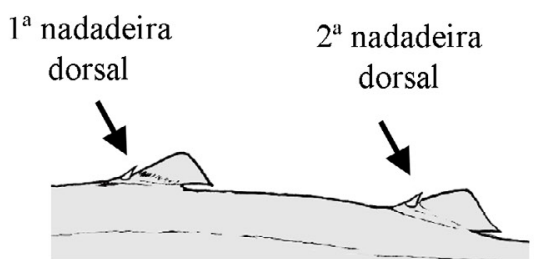

Fig. 52

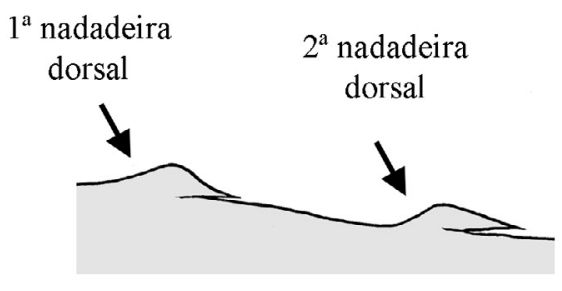

Fig. 53

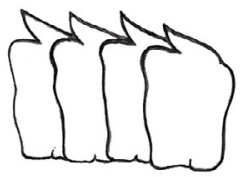

Fig.56

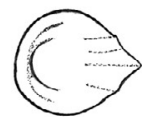

Fig. 57

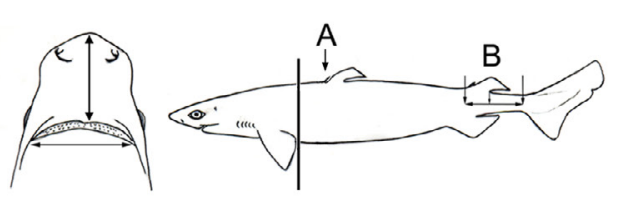

Fig. 58

Fig.59

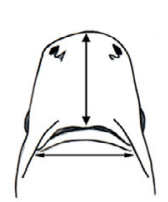

Fig.60

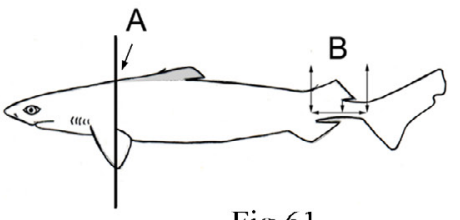

Fig. 61
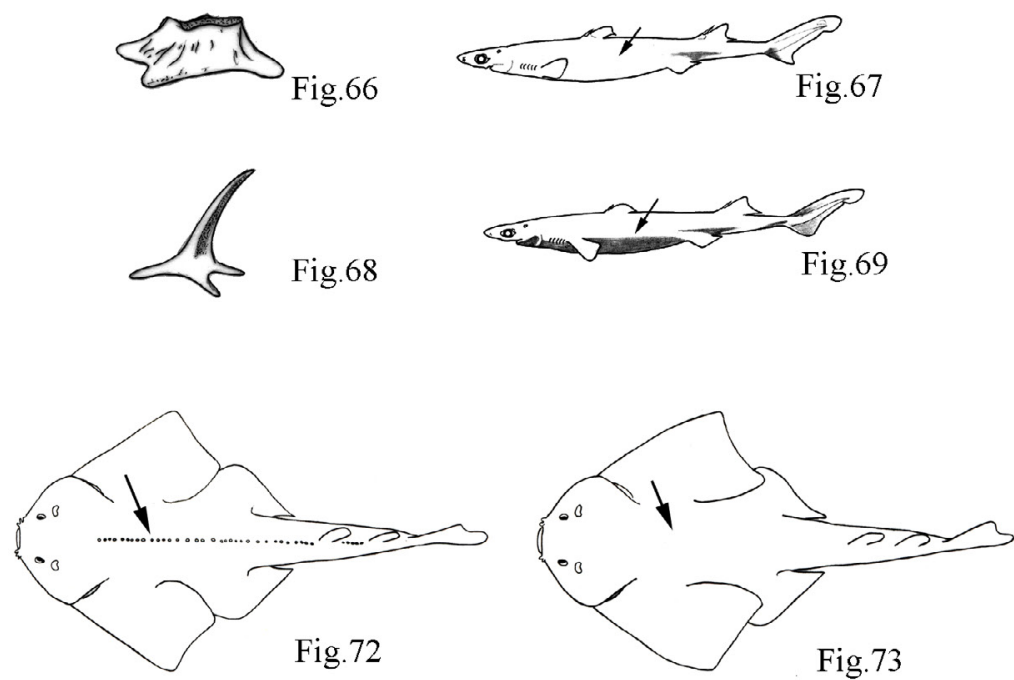

Revista Nordestina de Biologia | ISSN: 2236-1480 


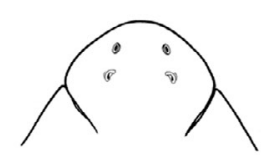

Fig. 74

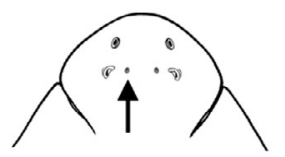

Fig. 75

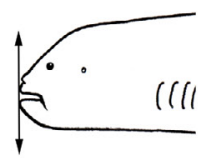

Fig. 79

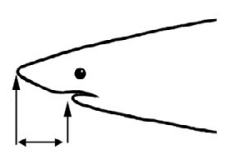

Fig. 80
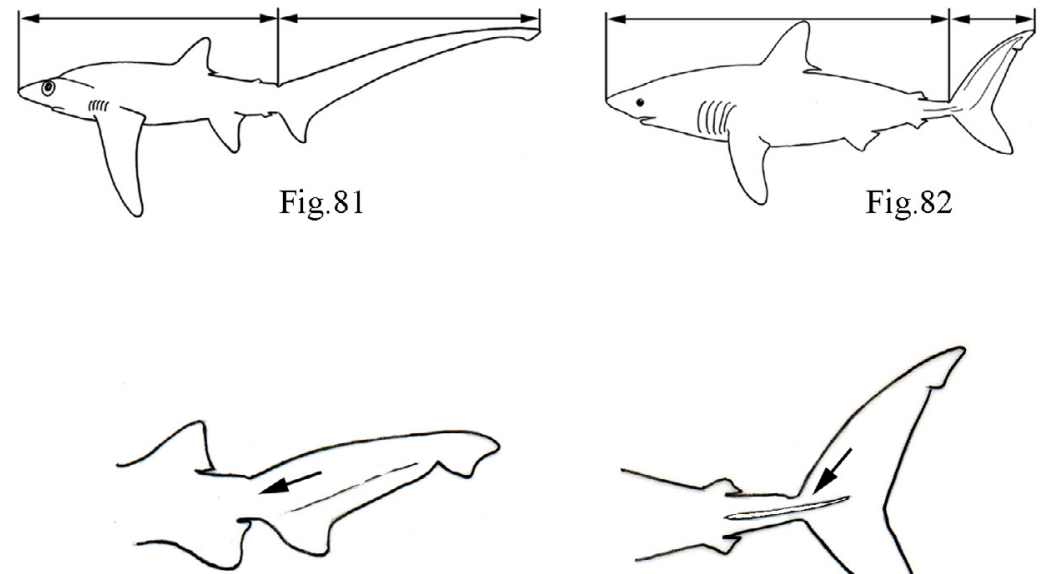

Fig. 83
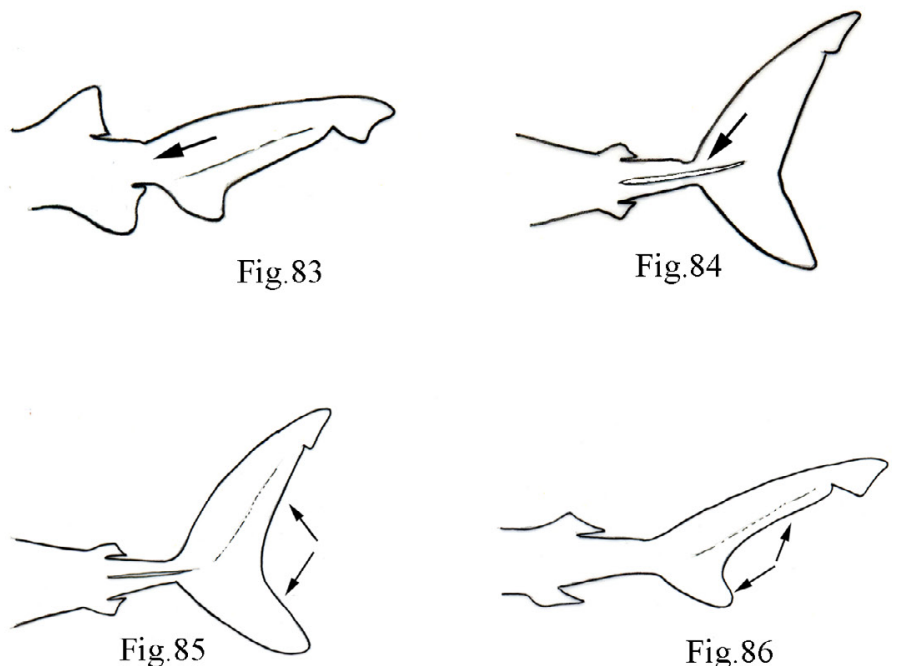

Fig. 86

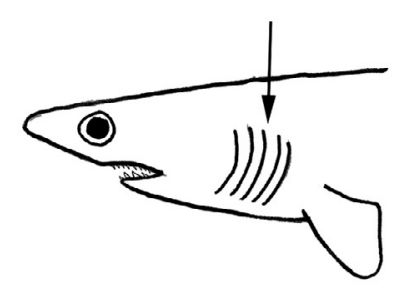

Fig. 88 
Prancha VII
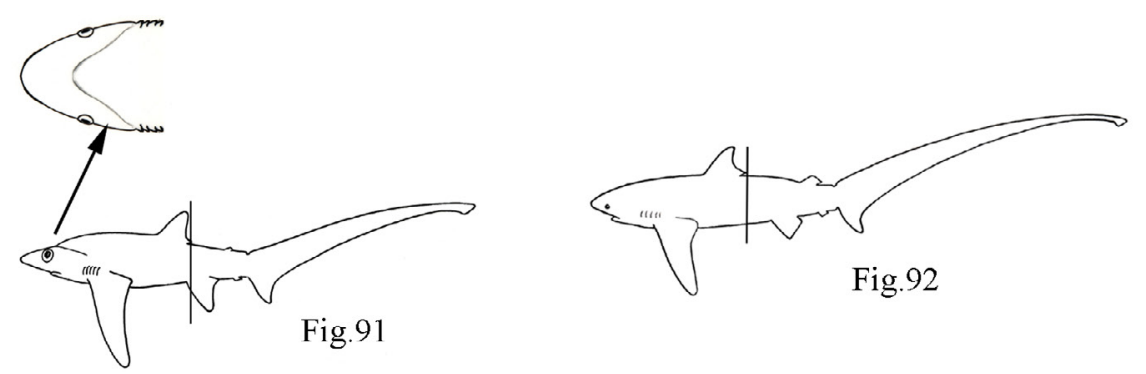

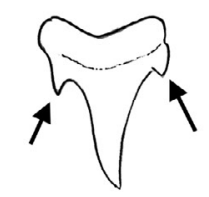

Fig. 100
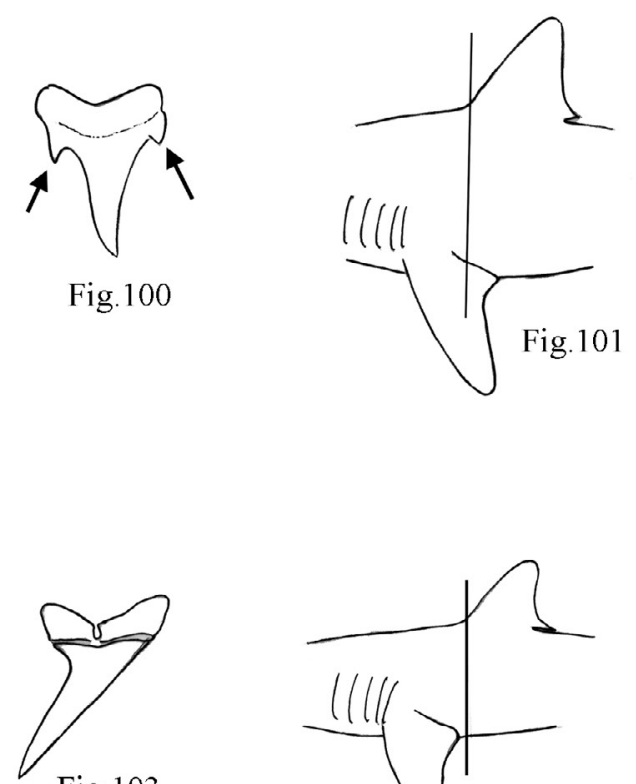

Fig. 103

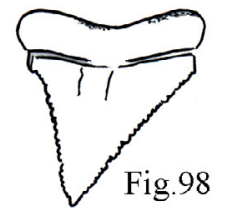

Fig.98
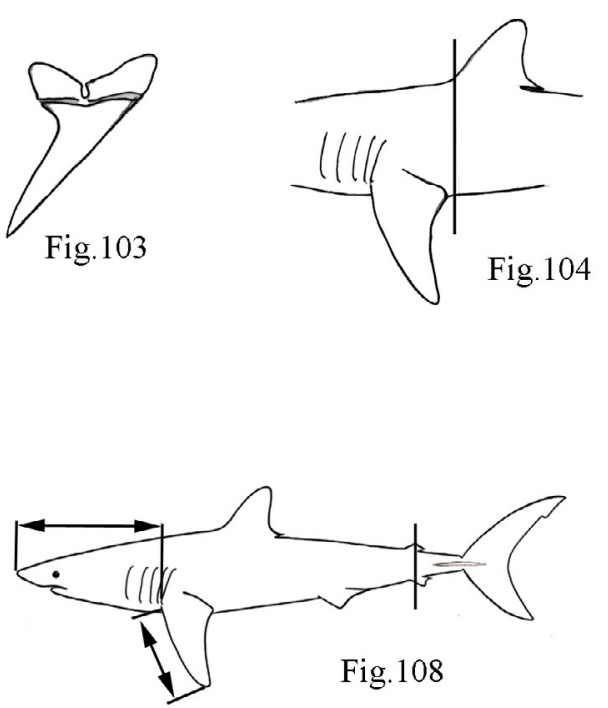

Fig.99

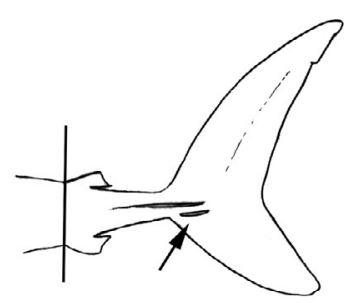

Fig. 102

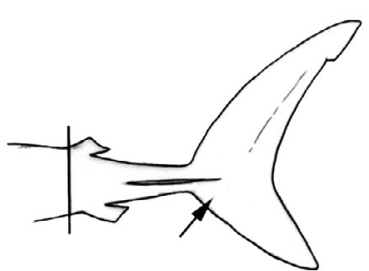

Fig. 105

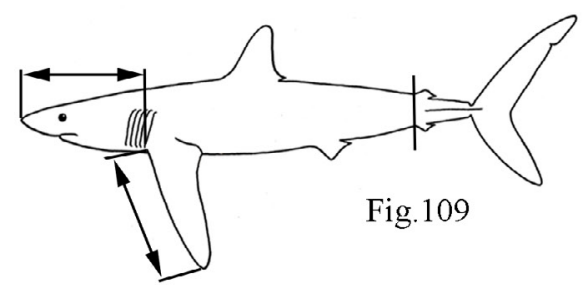




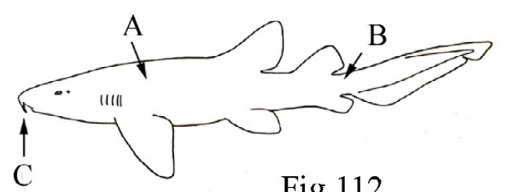

Fig. 112

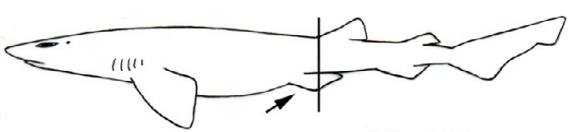

Fig. 116

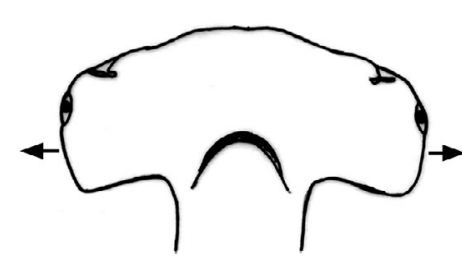

Fig118

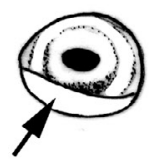

Fig. 120
Fig. 121

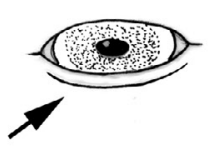

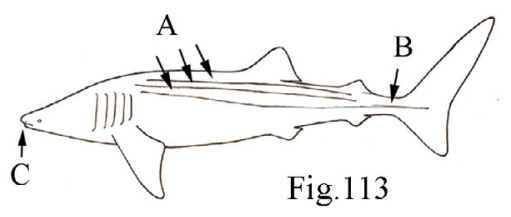

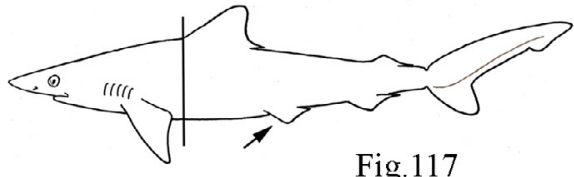

Fig. 117

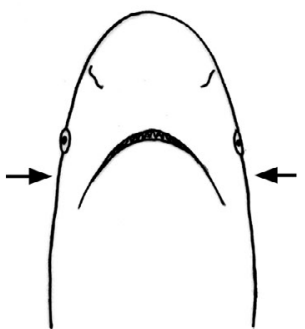

Fig.119

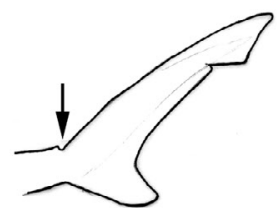

Fig. 122

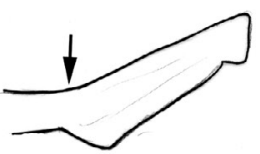

Fig. 123

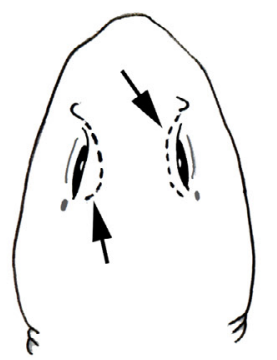

Fig. 124

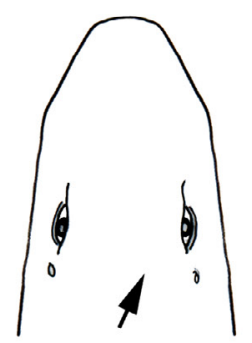

Fig. 125 


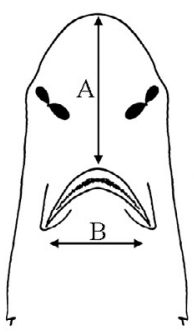

Fig. 126

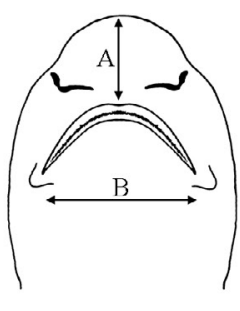

Fig. 127

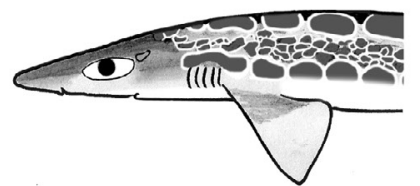

Fig. 128
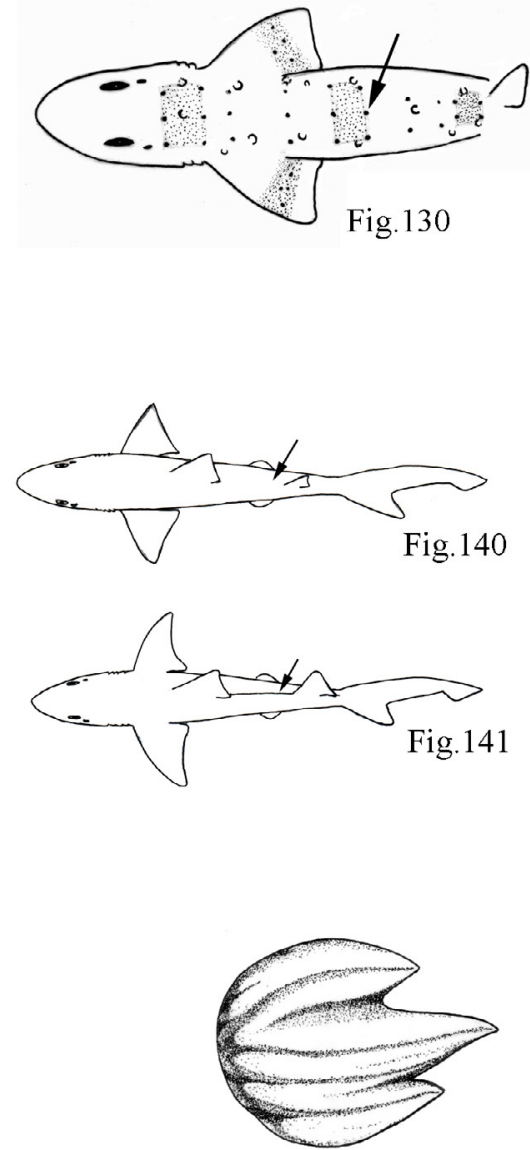

Fig. 145

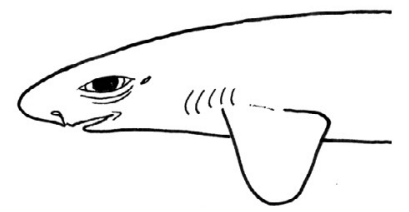

Fig. 129
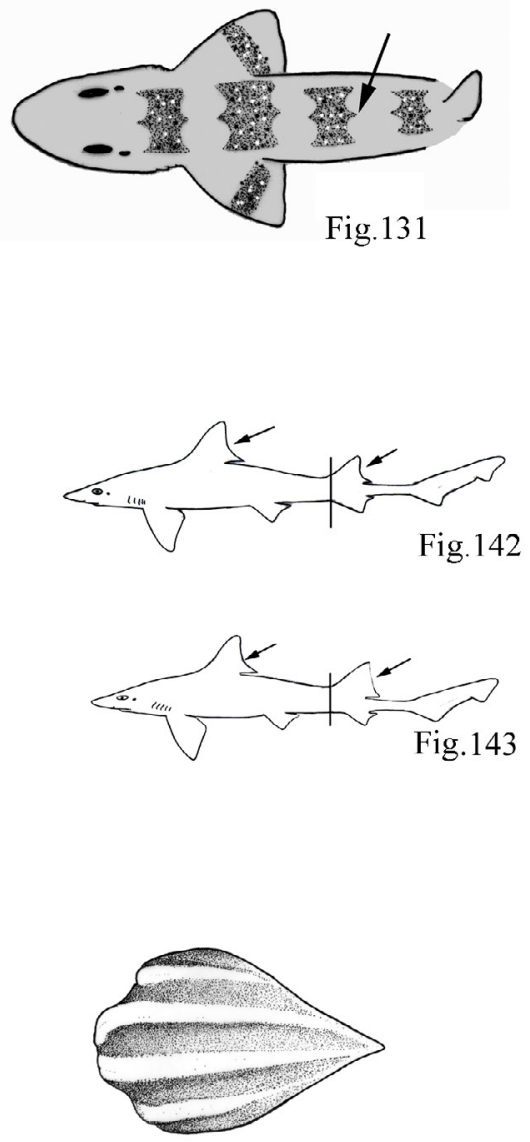

Fig. 146 


\section{Prancha X}

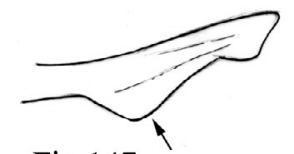

Fig. 147

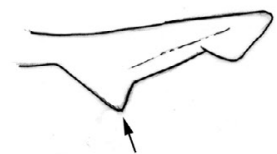

Fig. 150

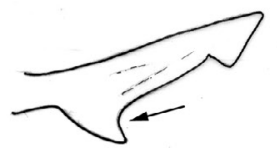

Fig. 152

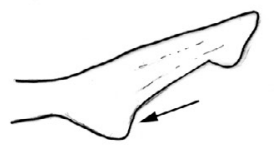

Fig. 155

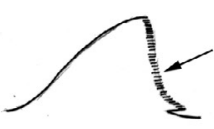

Fig. 148

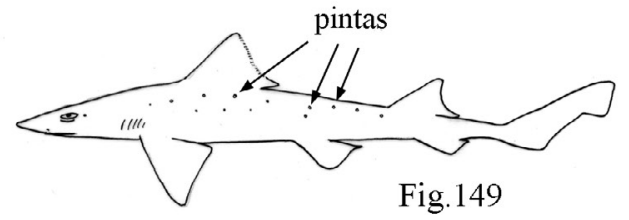

Fig. 149

Fig. 151

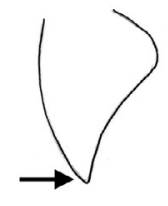

Fig. 153

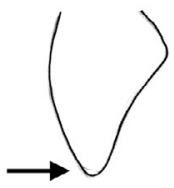

Fig. 156

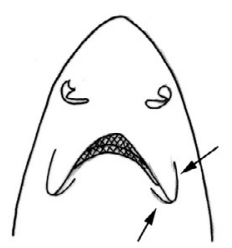

Fig. 154

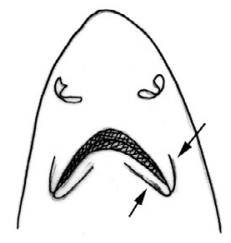

Fig. 157

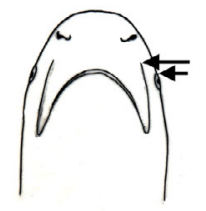

Fig. 162

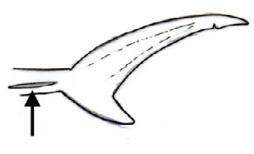

Fig. 163

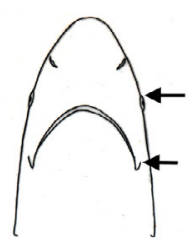

Fig. 164

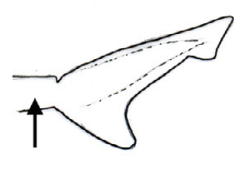

Fig. 165 


\section{Prancha XI}

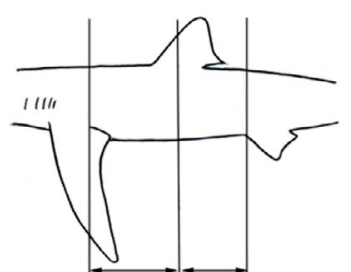

Fig. 166

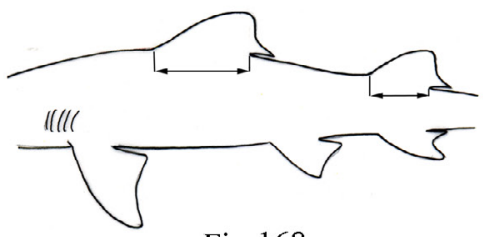

Fig. 168

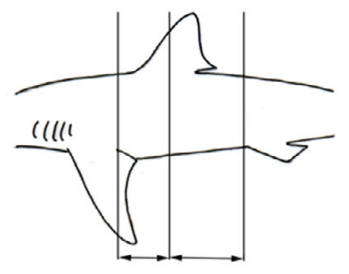

Fig. 167
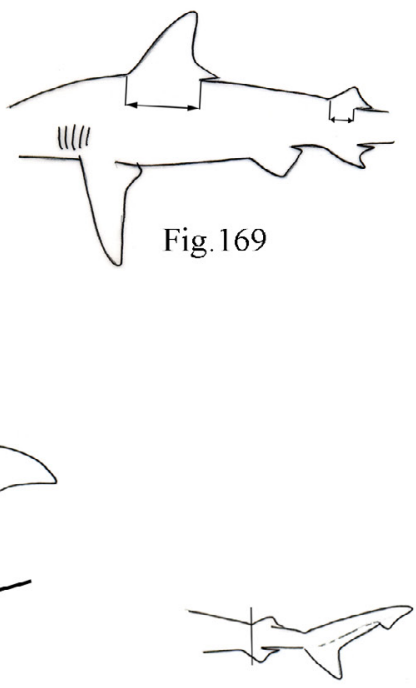

Fig. 172

Fig. 170
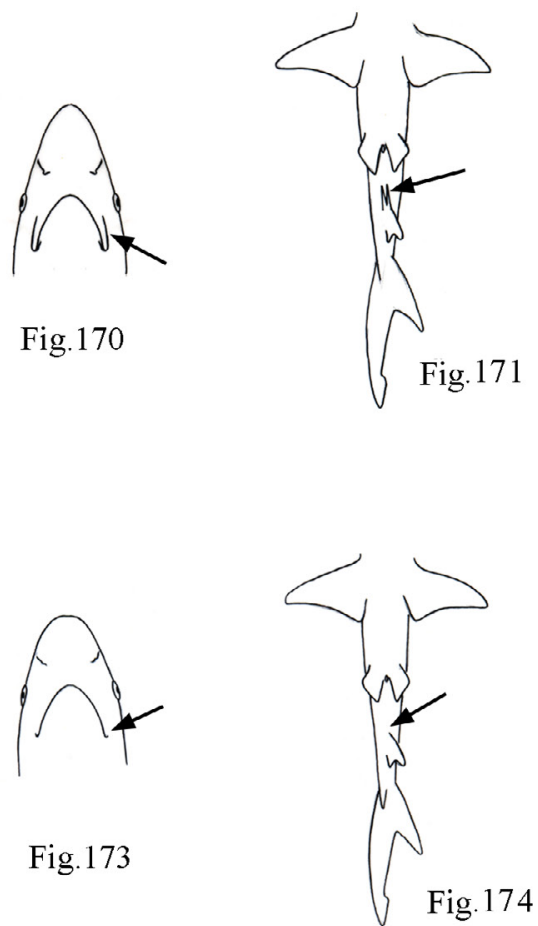

Fig. 173

Fig. 174 


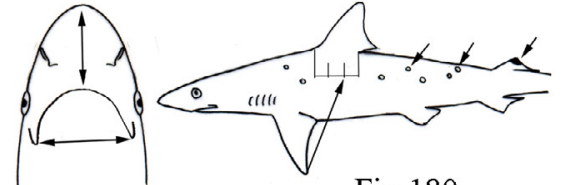

Fig. 180

Fig. 179

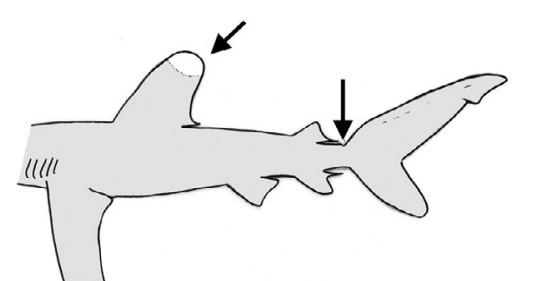

Fig. 185

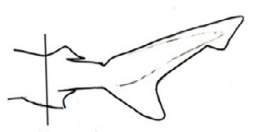

Fig. 187
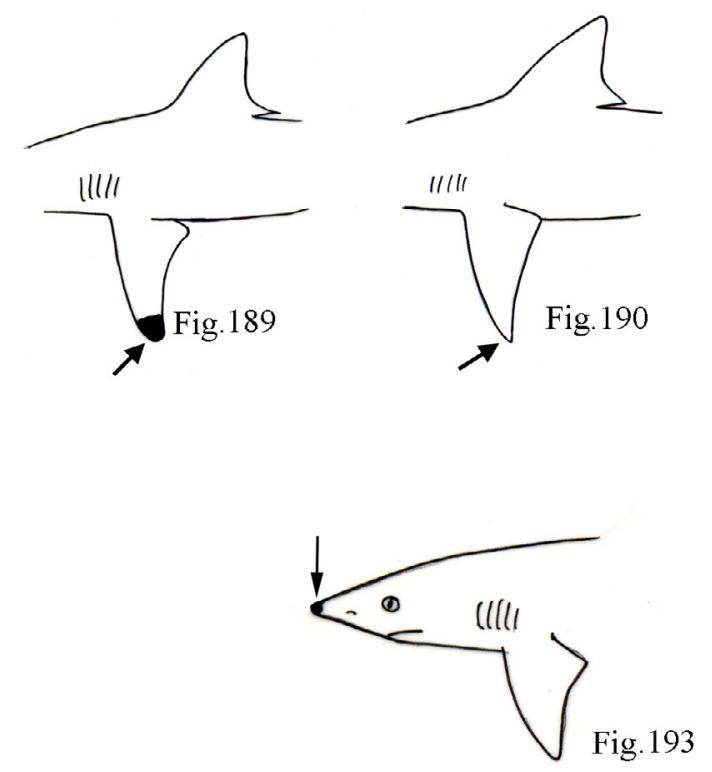

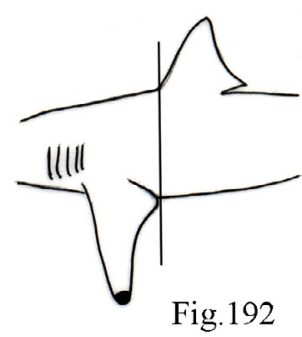

Fig.191
Fig. 182

Fig. 181
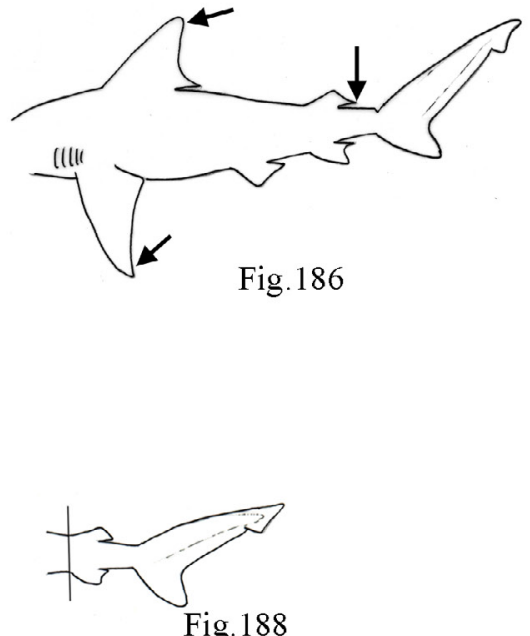

Fig. 188

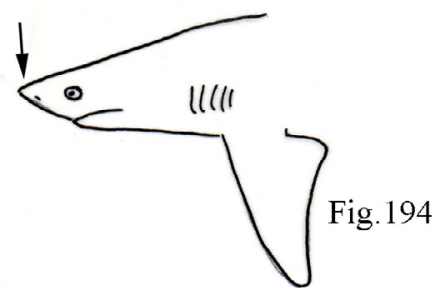


Prancha XIII

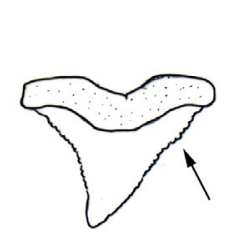

Fig. 195

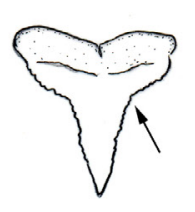

Fig. 196

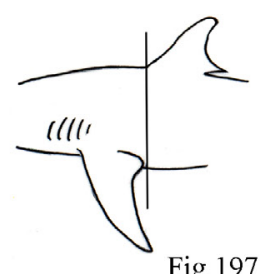

Fig. 197
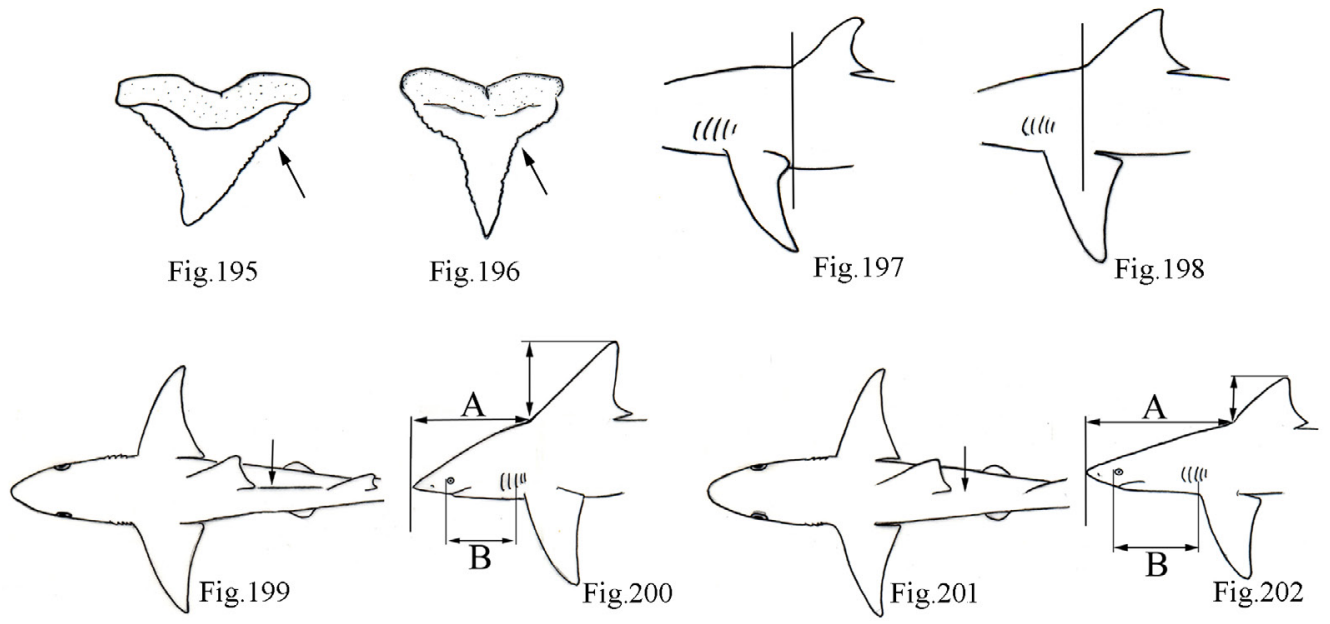

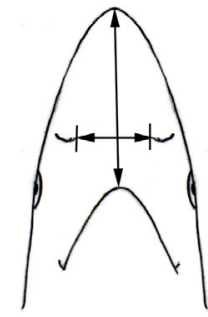

Fig. 203

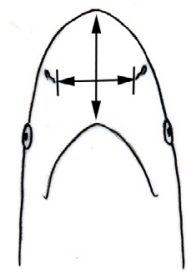

Fig. 204
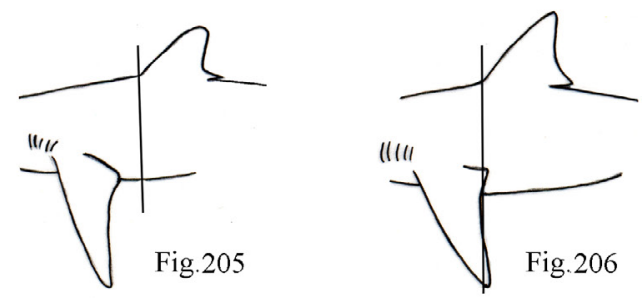

\section{$\Leftrightarrow$}

Fig. 222

Fig. 221

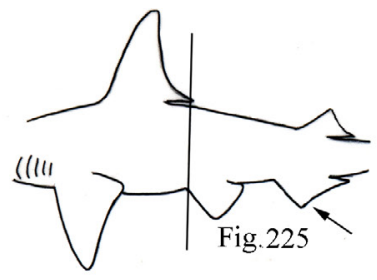

Fig. 223

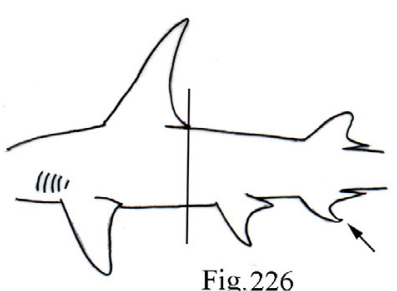

Fig. 226

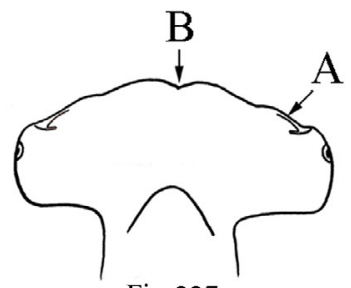

Fig. 227

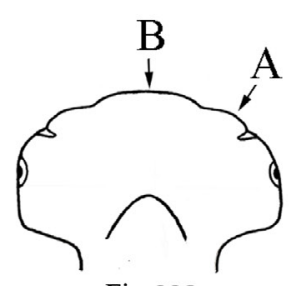

Fig. 228 
Prancha XIV

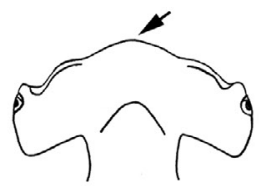

Fig. 229

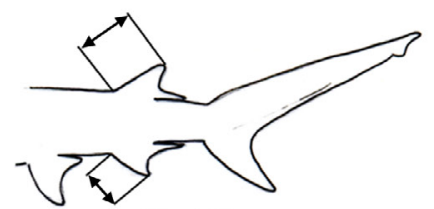

Fig. 232<smiles>CCCCCCCCCCCCCCCCC</smiles>

Fig. 230

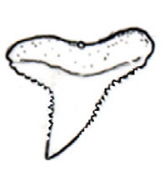

Fig. 231

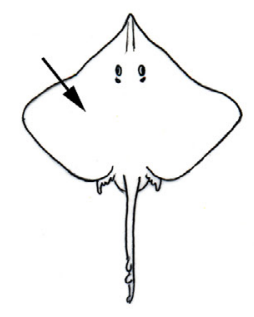

Fig. 242

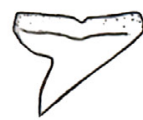

Fig. 233

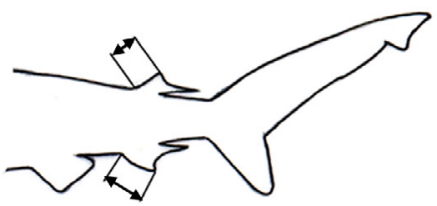

Fig. 234

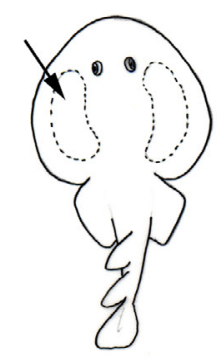

Fig.241

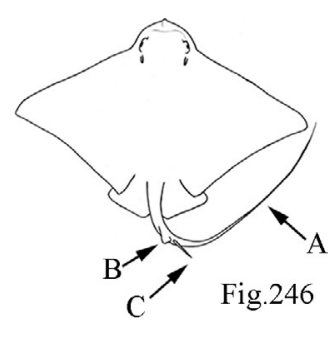

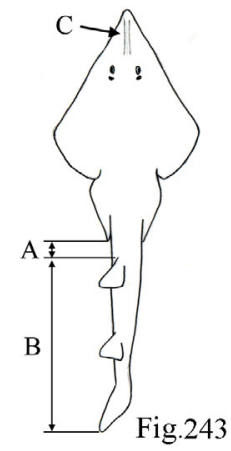

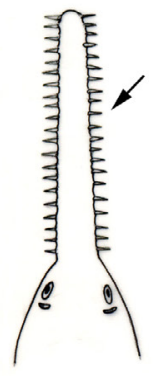

Fig. 244

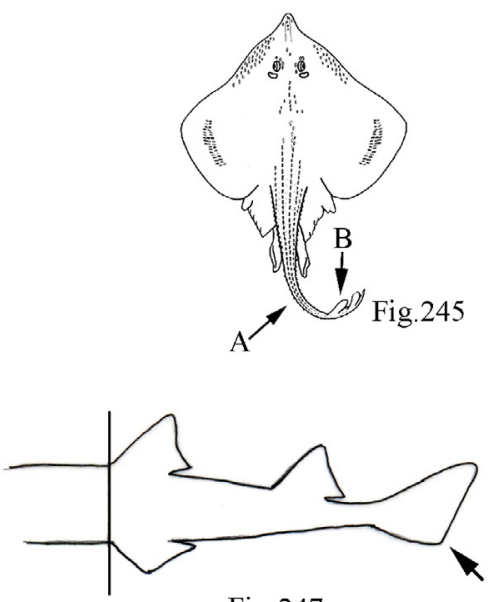

Fig. 247

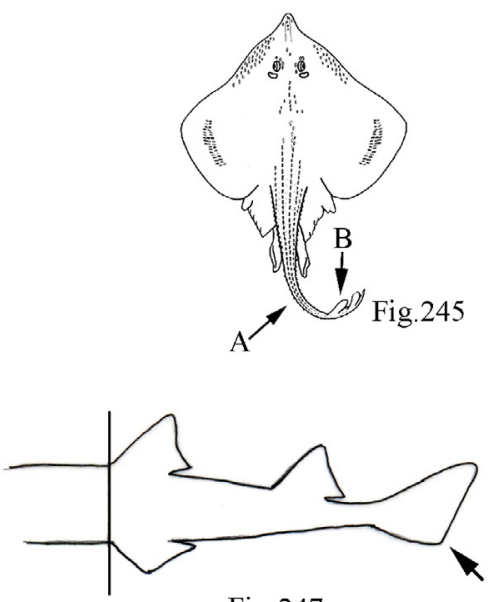

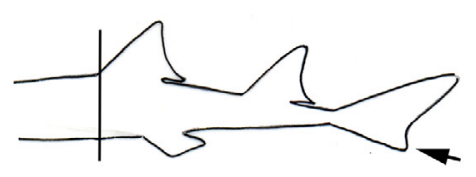

Fig. 248 
Prancha XV
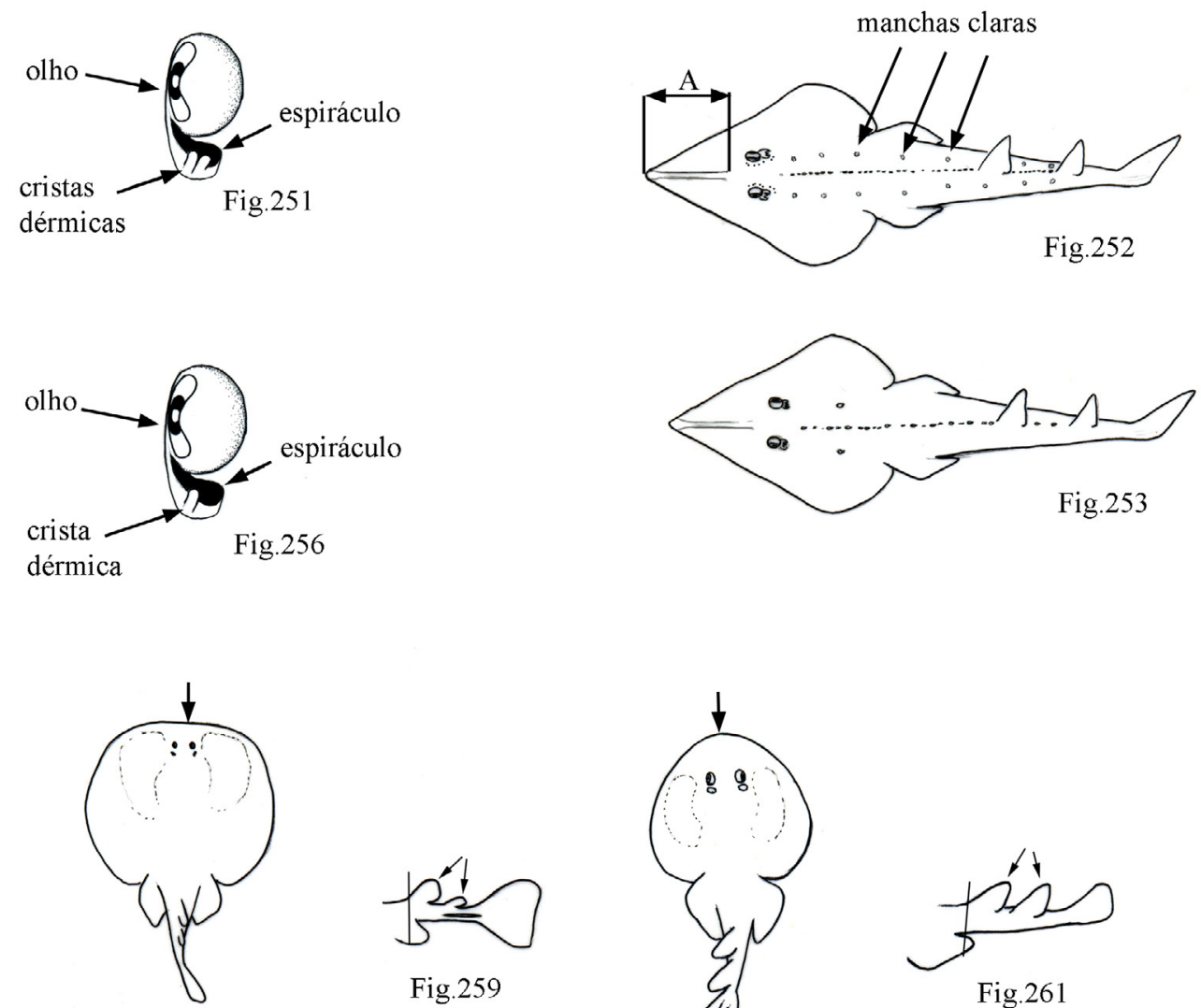

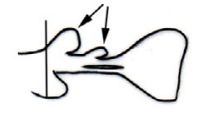

Fig. 259

Fig. 258

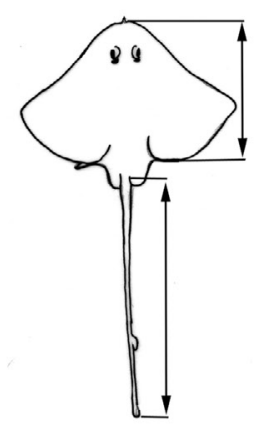

Fig.264

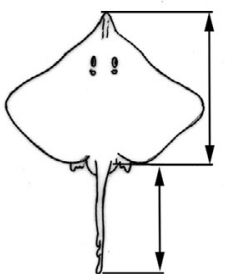

Fig. 265

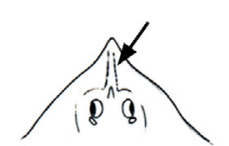

Fig. 266

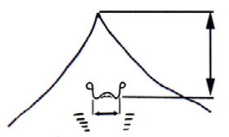

Fig. 269

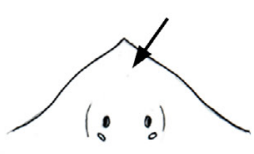

Fig. 267

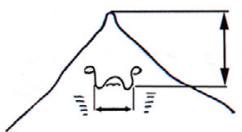

Fig. 270 

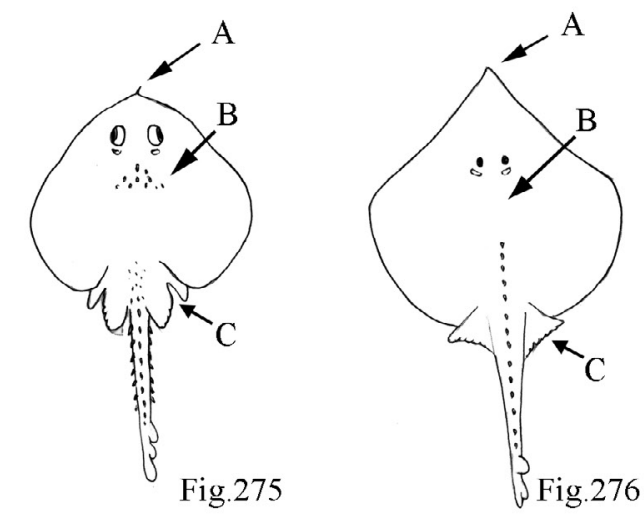

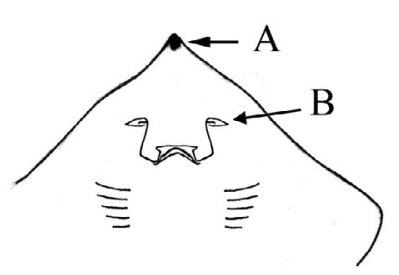

Fig. 277

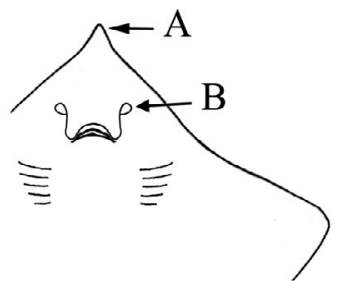

Fig. 278

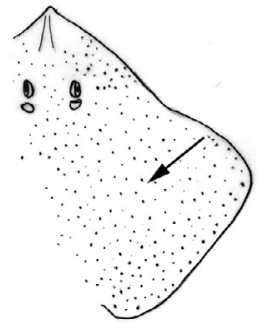

Fig. 279

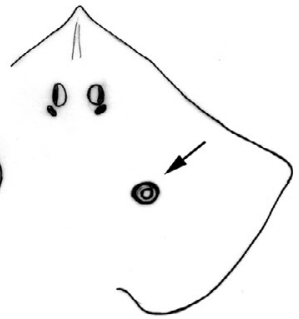

Fig.280

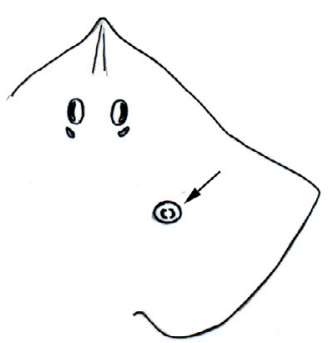

Fig.281

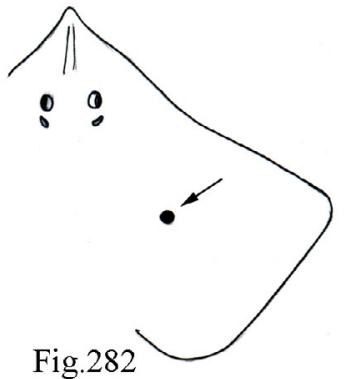

Fig. 282

Fig. 290
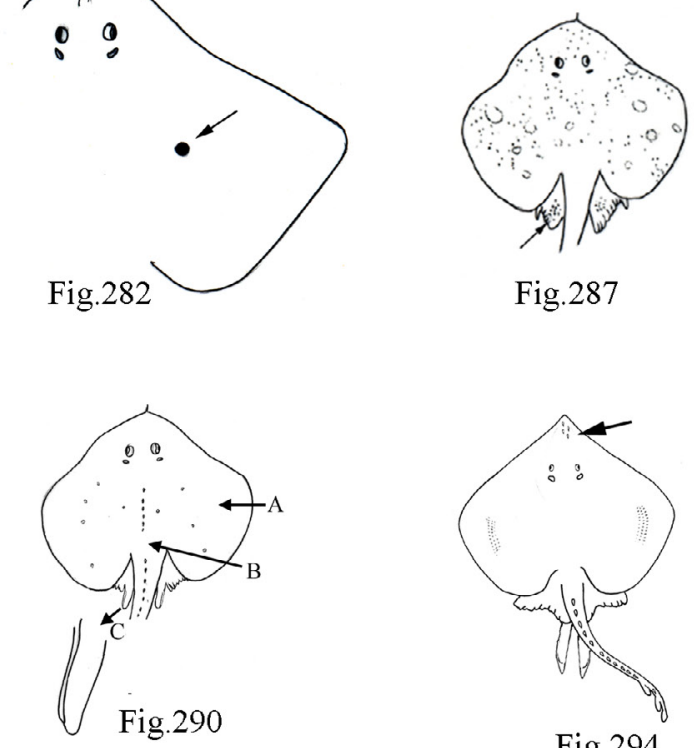

Fig. 287

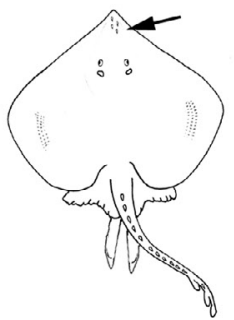

Fig.294

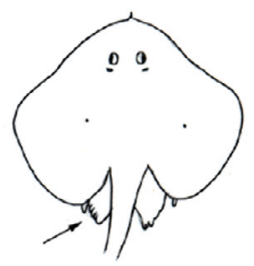

Fig. 288

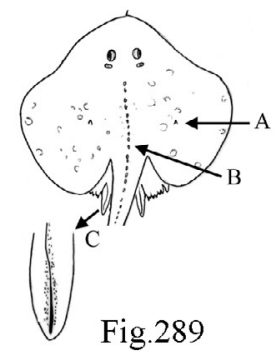

Fig.289

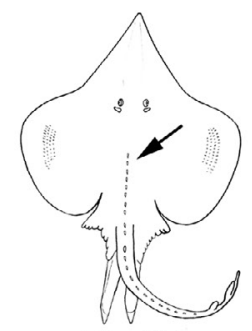

Fig. 295 


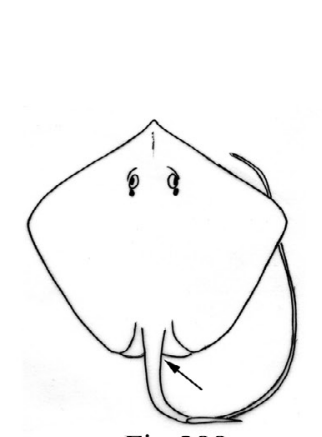

Fig. 299

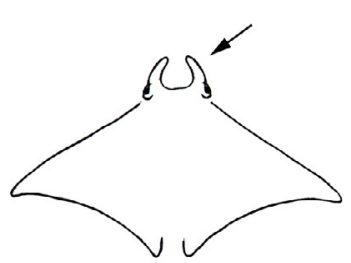

Fig. 303

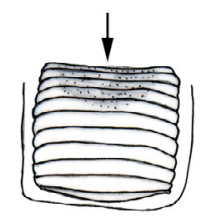

Fig.307

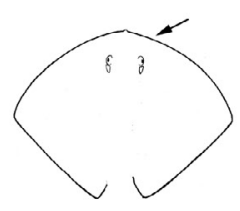

Fig.313

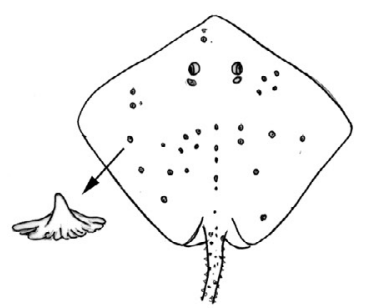

Fig. 317

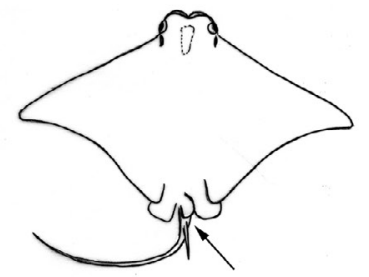

Fig. 300

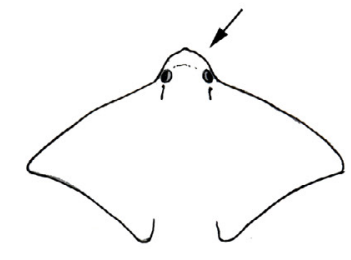

Fig. 304

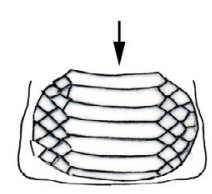

Fig. 308

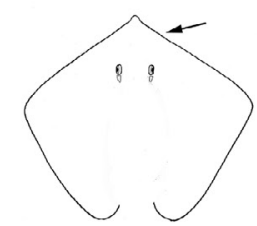

Fig. 314

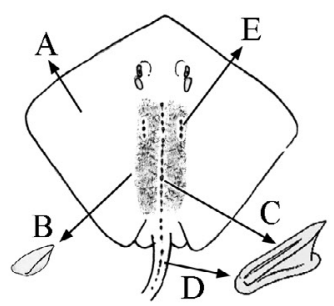

Fig. 318

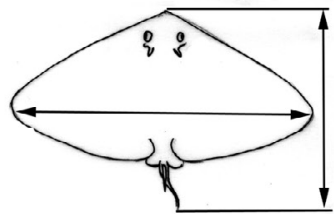

Fig.301

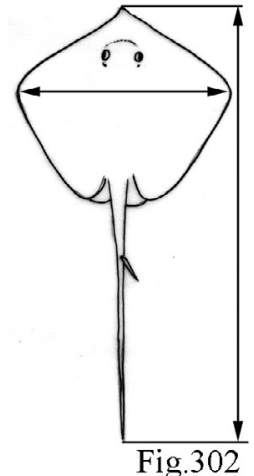

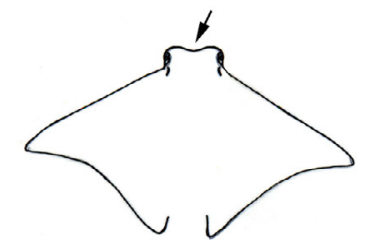

Fig. 305

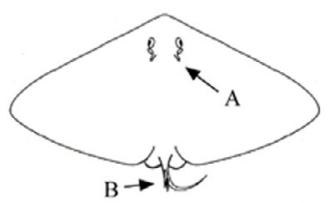

Fig.309

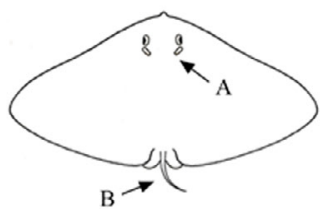

Fig. 310

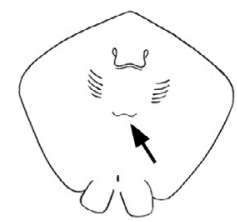

Fig. 315

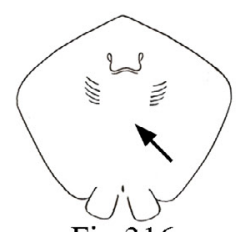

Fig.316

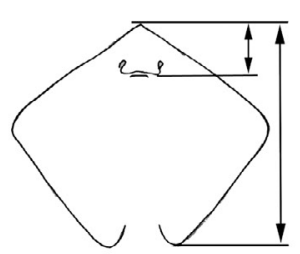

Fig. 321

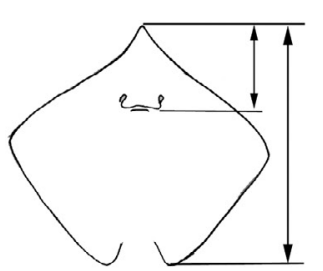

Fig. 322 


\section{Prancha XVIII}

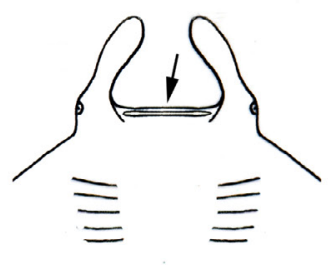

Fig.326

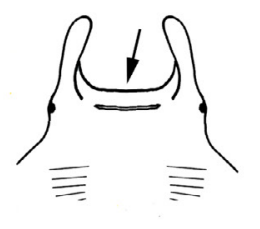

Fig. 327

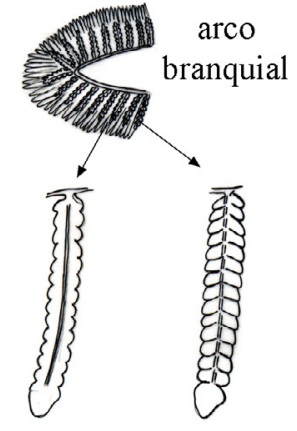

Fig.328 Fig.329

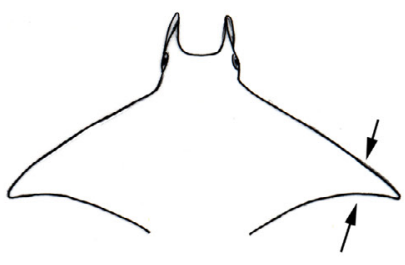

Fig. 330

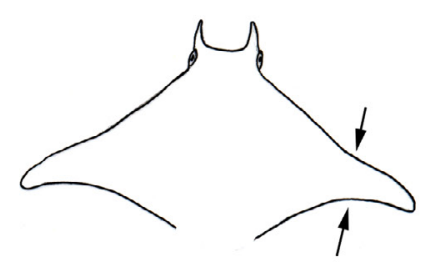

Fig.331

Fig. 331

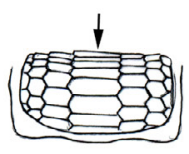

Fig. 337
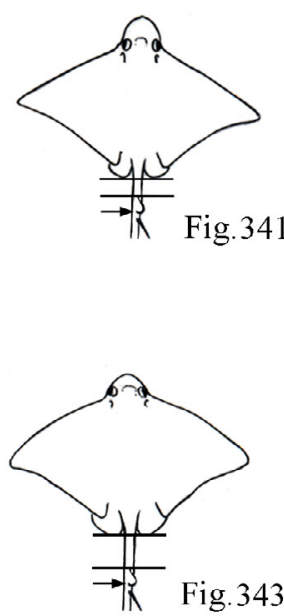

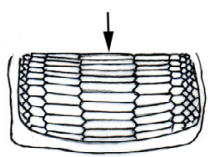

Fig. 338

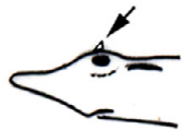

Fig. 342

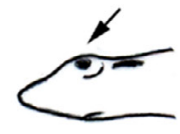

Fig.344 